Prepared in cooperation with the Arkansas Department of Environmental Quality

\title{
Low-Flow Characteristics and Regionalization of Low-Flow Characteristics for Selected Streams in Arkansas
}
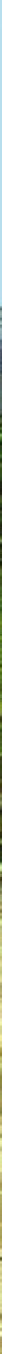

Scientific Investigations Report 2008-5065

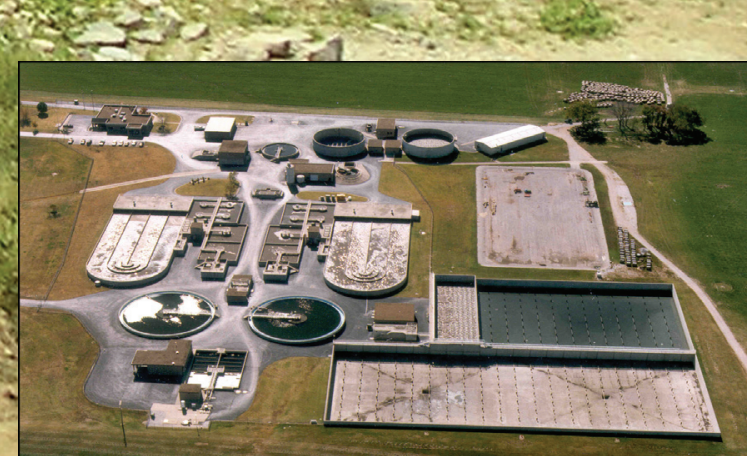

U.S. Department of the Interior U.S. Geological Survey 
Cover photograph. Crooked Creek at the State Highway 14 bridge crossing at Yellville, Arkansas. Photograph by U.S. Geological Survey. Inset photograph is Wastewater Treatment Plant, Rogers, Arkansas (courtesy of Rogers Water Utilities). 


\section{Low-Flow Characteristics and Regionalization of Low-Flow Characteristics for Selected Streams in Arkansas}

By Jaysson E. Funkhouser, Ken Eng, and Matthew W. Moix

Prepared in cooperation with the Arkansas Department of Environmental Quality

Scientific Investigations Report 2008-5065

U.S. Department of the Interior

U.S. Geological Survey 


\section{U.S. Department of the Interior DIRK KEMPTHORNE, Secretary}

\section{U.S. Geological Survey \\ Mark D. Myers, Director}

\section{U.S. Geological Survey, Reston, Virginia: 2008}

For product and ordering information:

World Wide Web: http://www.usgs.gov/pubprod

Telephone: 1-888-ASK-USGS

For more information on the USGS--the Federal source for science about the Earth, its natural and living resources, natural hazards, and the environment:

World Wide Web: http://www.usgs.gov

Telephone: 1-888-ASK-USGS

Any use of trade, product, or firm names is for descriptive purposes only and does not imply endorsement by the U.S. Government.

Although this report is in the public domain, permission must be secured from the individual copyright owners to reproduce any copyrighted materials contained within this report.

Suggested citation:

Funkhouser, J.E., Eng, K., and Moix, M.W., 2008, Low-flow characteristics and regionalization of low-flow characteristics for selected streams in Arkansas: U.S. Geological Survey Scientific Investigations Report 2008-5065, 161 p. 


\section{Contents}

Abstract

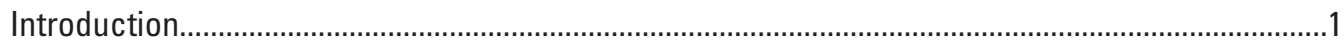

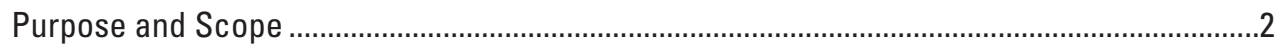

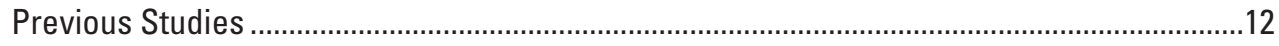

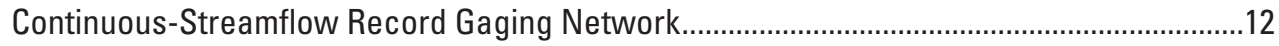

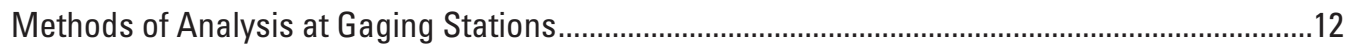

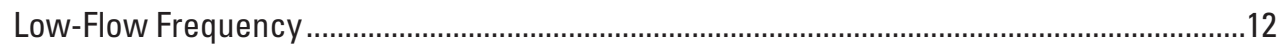

Calculation of Low-Flow Characteristics of Continuous-Streamflow Record Gaging

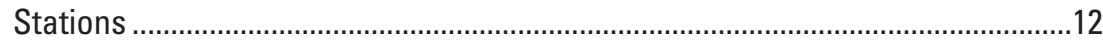

Calculation of Low-Flow Characteristics at Partial-Record Gaging Stations ................13

Calculation of Low-Flow Characteristics at Partial-Record Gaging Stations Using the Base-Flow Correlation Method ......................................................................13

Calculation of Low-Flow Characteristics at Partial-Record Stations Using the

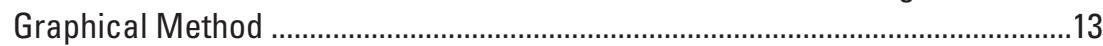

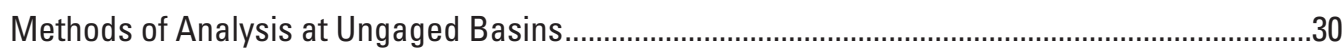

Regional Regression Models for Low-Flow Characteristics ................................................30

Basin Attributes Considered .........................................................................................

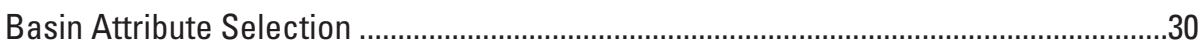

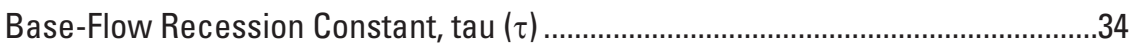

Performance Metrics for Evaluation of Regression Models .....................................34

Low-Flow Characteristics at Continuous-Streamflow and Partial-Record Gaging Stations..........39

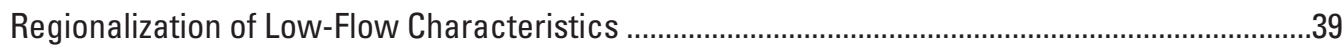

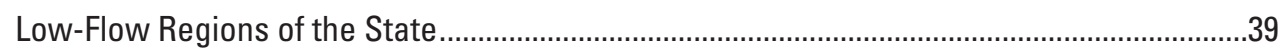

Low-Flow Characteristics at Ungaged Basins ……………...............................................

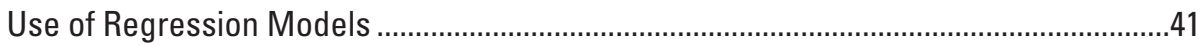

Use of Computer Program ............................................................................................53

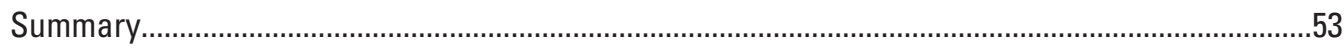

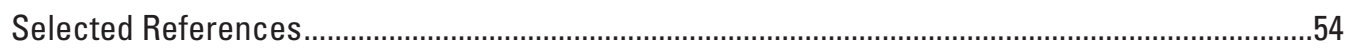

Appendix 1. Description of Base-Flow Correlation Method ………...........................................136

Appendix 2. Regional Regression Models ......................................................................137

Appendix 3. Basin Attributes Tested for Significance in the Regression Analysis ....................142

Appendix 4. Basin Attribute Selection ....................................................................................144 


\section{Figures}

1. Map showing continuous-streamflow record and partial-record gaging stations analyzed for low-flow characteristics

2. Graph showing relation between daily-mean discharge at continuous streamflowrecord gaging station Buffalo River near St. Joe, Arkansas, and measured discharge at partial-record station, Buffalo River near Boxley, Arkansas ........................................13

3-7. Maps showing:

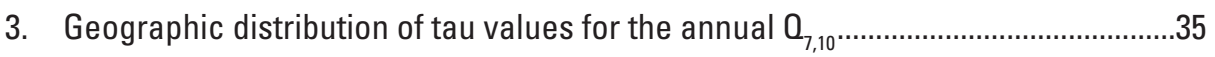

4. Geographical distribution of tau values for the November through

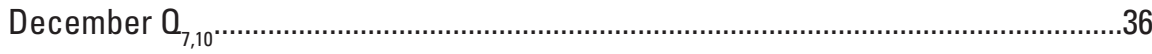

5. Geographical distribution of tau values for the January through

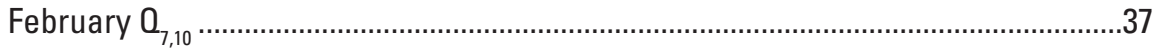

6. Geographical distribution of tau values for the March through April $0_{7,10} \ldots \ldots \ldots \ldots \ldots .38$

7. Physiographic sections of Arkansas ..................................................................

\section{Tables}

1. Continuous streamflow-record and partial-record gaging stations analyzed for lowflow characteristics

2. Partial-record gaging stations analyzed for low-flow characteristics and the method

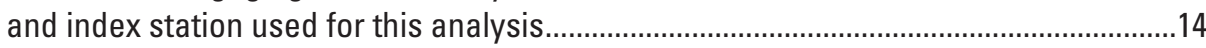

3. Basin attributes tested for significance in the regression analysis .................................31

4. Low-flow characteristics for continuous streamflow-record gaging stations having 10 or more years of streamflow record.............................................................58

5. Partial-record gaging stations analyzed for low-flow characteristics and the results of this analysis

6. Logistic regression models and associated performance metrics for each low-flow characteristic of interest...........................................................................................4

7. Multiple linear weighted least squares regression models for each region in

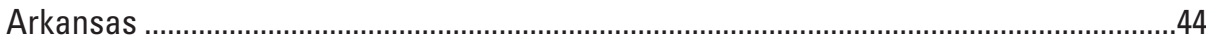

8. Continuous-streamflow and partial-record gaging stations used to form the

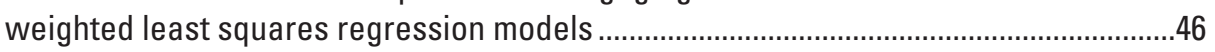

9. Logistic regression models: Basin attribute ranges ..................................................50

10. Weighted least squares regression models: Basin attribute ranges ..............................51

2-1. Statistical summary of the coefficient values used in the regression models for each

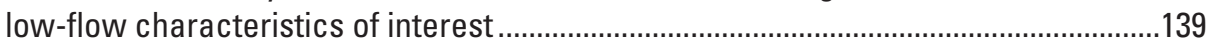

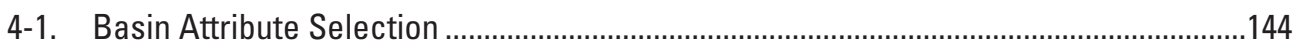

4-2. Values of basin attributes found to be significant in the regression model ..................145 


\section{Conversion Factors}

\begin{tabular}{lcl}
\hline \multicolumn{1}{c}{ Multiply } & \multicolumn{1}{c}{ By } & \multicolumn{1}{c}{ To obtain } \\
\hline inch (in.) & Length & \\
inch (in.) & 2.54 & centimeter $(\mathrm{cm})$ \\
foot (ft) & 25.4 & millimeter $(\mathrm{mm})$ \\
mile (mi) & 0.3048 & meter $(\mathrm{m})$ \\
\hline & 1.609 & kilometer $(\mathrm{km})$ \\
\hline section (640 acres or 1 square mile) & Area & \\
square mile $\left(\mathrm{mi}^{2}\right)$ & 259.0 & square hectometer $\left(\mathrm{hm}^{2}\right)$ \\
square mile $\left(\mathrm{mi}^{2}\right)$ & 259.0 & hectare $(\mathrm{ha})$ \\
\hline & 2.590 & square kilometer $\left(\mathrm{km}^{2)}\right.$ \\
\hline million gallons (Mgal) & Volume & \\
cubic foot $\left(\mathrm{ft}^{3}\right)$ & 3,785 & cubic meter $\left(\mathrm{m}^{3}\right)$ \\
\hline & 0.02832 & cubic meter $\left(\mathrm{m}^{3}\right)$ \\
\hline cubic foot per second $\left(\mathrm{ft}^{3} / \mathrm{s}\right)$ & Flow rate & \\
\hline
\end{tabular}

Vertical coordinate information is referenced to the North American Vertical Datum of 1988 (NAVD 88).

Horizontal coordinate information is referenced to the North American Datum of 1983 (NAD 83).

Altitude, as used in this report, refers to distance above the vertical datum. 


\title{
Low-Flow Characteristics and Regionalization of Low- Flow Characteristics for Selected Streams in Arkansas
}

\author{
By Jaysson E. Funkhouser, Ken Eng, and Matthew W. Moix
}

\section{Abstract}

Water use in Arkansas has increased dramatically in recent years. Since 1990, the use of water for all purposes except power generation has increased 53 percent $(4,004$ cubic feet per second in 1990 to 6,113 cubic feet per second in 2005). The biggest users are agriculture (90 percent), municipal water supply (4 percent) and industrial supply (2 percent). As the population of the State continues to grow, so does the demand for the State's water resources.

The low-flow characteristics of a stream ultimately affect its utilization by humans. Specific information on the lowflow characteristics of streams is essential to State watermanagement agencies such as the Arkansas Department of Environmental Quality, the Arkansas Natural Resources Commission, and the Arkansas Game and Fish Commission when dealing with problems related to irrigation, municipal and industrial water supplies, fish and wildlife conservation, and dilution of waste. Low-flow frequency data are of particular value to management agencies responsible for the development and management of the State's water resources.

This report contains the low-flow characteristics for 70 active continuous-streamflow record gaging stations, 59 inactive continuous-streamflow record stations, and 101 partialrecord gaging stations. These characteristics are the annual 7-day, 10-year low flow and the annual 7-day, 2-year low flow, and the seasonal, bimonthly, and monthly 7-day, 10-year low flow for the 129 active and inactive continuous-streamflow record and 101 partial-record gaging stations.

Low-flow characteristics were computed on the basis of streamflow data for the period of record through September 2005 for the continuous-streamflow record and partial-record streamflow gaging stations. The low-flow characteristics of these continuous- and partial-record streamflow gaging stations were utilized in a regional regression analysis to produce equations for estimating the annual, seasonal, bimonthly, and monthly (November through April) 7-day, 10-year low flows and the annual 7-day, 2-year low flow for ungaged streams in the western two-thirds of Arkansas.

\section{Introduction}

Water use in Arkansas has increased dramatically in recent years. Since 1990, the use of water for all purposes except power generation has increased 53 percent $(4,004$ cubic feet per second $\left(\mathrm{ft}^{3} / \mathrm{s}\right)$ in 1990 to $6,113 \mathrm{ft}^{3} / \mathrm{s}$ in 2005). The biggest users are agriculture ( 90 percent), municipal water supply (4 percent) and industrial supply ( 2 percent) (Terrance W. Holland, U.S. Geological Survey, written commun., 2007). As the population of Arkansas continues to grow, so does the demand for the State's water resources.

The low-flow characteristics of a stream ultimately affect its utilization by humans. Few streams in Arkansas are completely unaffected by regulation or diversion (Ludwig, 1992). There are approximately 2,600 lakes and reservoirs in Arkansas with surface areas of 5 acres or more (Ludwig, 1992). The majority of every major drainage basin in the State contains one or more of these lakes (Arkansas Soil and Water Conservation Commission, 1981). The effects of regulation are slight downstream from small retention reservoirs that are used for sediment control, livestock wastewater-treatment facilities, and small municipal-water supplies. However, in basins where major control structures have been built or large numbers of diversions for irrigation occur, streamflow no longer reflects short-term variations in natural flow.

In some instances, municipal water supplies are withdrawn upstream from a gaging station and treated wastewater is discharged into another drainage basin. For example, Beaver Water District withdraws $80 \mathrm{Mgal} / \mathrm{d}\left(52 \mathrm{ft}^{3} / \mathrm{s}\right)$ from the White River Basin (Beaver Lake). Treated wastewater from municipalities served by the Beaver Water District is discharged into the White River and Arkansas River Basins (Galloway and others, 2005; Galloway and Green, 2006).

Specific information on the low-flow characteristics of streams is essential to State water-management agencies such as the Arkansas Department of Environmental Quality (ADEQ), Arkansas Natural Resources Commission (ANRC), and Arkansas Game and Fish Commission (AGFC) when dealing with problems related to irrigation, municipal and industrial water supplies, fish and wildlife conservation, and 
dilution of waste. Low-flow frequency data are of particular value to management agencies responsible for the development and management of the State's water resources.

The ADEQ issues and periodically renews National Pollutant Discharge Elimination System (NPDES) permits to municipalities, industries, and other entities with facilities desiring to discharge a treated wastewater into a surface water of the State. For the purpose of protecting public health and aquatic environments, NPDES permits issued by the ADEQ impose limits on the quantity of pollutants in wastewater discharge to surface waters ensuring compliance with Federal regulations and Arkansas water-quality standards (Arkansas Department of Environmental Quality, written commun., 2004).

Historically, limits imposed by NPDES permits issued by the ADEQ for wastewater discharge into streams have been based upon the annual 7-day, 10-year low flow $\left(\mathrm{Q}_{7,10}\right)$ at the location of the wastewater discharge. In 2005, the ADEQ acquired approval from the U.S. Environmental Protection Agency (USEPA) to issue NPDES permits with limits for ammonia toxicity based upon a monthly $\mathrm{Q}_{7,10}$ during the months of November through April. This approval allows regulatory agencies, such as the ADEQ, to better manage the available water resources by allowing an increase of wastewater discharge into streams during periods of higher flows that do not occur in the period of July through October in Arkansas. Consequently, low flow characteristics for the November through April period are also of interest.

The $\mathrm{Q}_{7,10}$ is widely used in addressing water-quality regulatory issues and represents the averaged consecutive 7-day minimum discharge that is not exceeded 9 out of every 10 years. The $\mathrm{Q}_{7,2}$ also is used in addressing water-quality regulatory issues and represents the averaged consecutive 7-day minimum discharge that is not exceeded 1 out of every 2 years. In Arkansas, the minimum 7-day average flow $\left(\mathrm{Q}_{7}\right)$ generally occurs between July and October during the dry season (late summer and early fall). At any given stream location during the remainder of the year, the minimum $\mathrm{Q}_{7}$ is usually higher.

Low-flow analyses typically are based upon an annual series with values that are considered random and independent. When the streamflow record is partitioned into shorter time-period segments of seasons or months, the risk of the minimum $\mathrm{Q}_{7}$ falling across them increases (that is, the averaged consecutive 7-day minimum discharge for a given year may occur between the last few days of October and the first few days of November). However, the introduction of seasonal and monthly low-flow frequency analyses enables water planners to better estimate streamflow behavior for a given month or season.

To provide the low-flow frequency data needed by the various water-management agencies, the U.S. Geological Survey (USGS) currently (2007) collects streamflow data at more than 130 gaging stations throughout the State. Periodically, these data are analyzed by the USGS to update the lowflow characteristics of streams analyzed in previous low-flow studies in the State. Data used in the streamflow analyses presented in this report were collected by the USGS in cooperation with many State and Federal agencies, principally the ADEQ, ANRC, and the U.S. Army Corps of Engineers. The analysis of the data and preparation of this report were done in cooperation with the ADEQ.

\section{Purpose and Scope}

The purpose of this report is to present the low-flow characteristics for:

- 70 active continuous-streamflow record gaging stations,

- 59 inactive continuous-streamflow record stations,

- 101 partial-record stations,

and to present regional regression equations for predicting selected low-flow characteristics for streams in ungaged basins in the western two-thirds of Arkansas. These characteristics and regressions equations were calculated using streamflow records collected through September 2005. The report updates previously published low-flow characteristics for streams in Arkansas and presents low-flow characteristics for streamflow gaging stations established after 1990. In addition, the report also includes estimates of the annual $\mathrm{Q}_{7,10}$ and $\mathrm{Q}_{7,2}$ and the seasonal, bimonthly, and monthly $\mathrm{Q}_{7,10}$ for the 129 active and inactive continuous-streamflow record and 101 partial-record gaging stations, which were not provided in previous low-flow reports. Low-flow characteristics were computed on the basis of streamflow data for the period of record for discontinued continuous-streamflow record gaging stations and through September 2005 for active continuous-streamflow record and partial-record streamflow gaging stations. The low-flow characteristics of these continuous- and partial-record streamflow gaging stations were utilized in a regional regression analysis to produce equations for estimating the annual, seasonal, bimonthly, and monthly (November through April) $\mathrm{Q}_{7,10}$ and the annual $Q_{7,2}$ for streams in ungaged basins in the western two-thirds of Arkansas (fig. 1) (table 1). The eastern onethird of Arkansas has been excluded from the study because extensive irrigation practices render it impossible to estimate low-flow characteristics at gaged or partial-record streamflowgaging stations or to determine equations to estimate low-flow characteristics in this region. A computer program is included on a compact disk at the back of the report for calculation of low-flow characteristics.

This report is an update, based on the additional period of record (1990 - 2005), of the information contained in Ludwig (1992) and includes an ordinary least squares (OLS) logistic regression model and a multiple linear regression model with a weighted least squares parameter estimation procedure to estimate the annual $\mathrm{Q}_{7,2}$ and $\mathrm{Q}_{7,10}$ as well as the seasonal, bimonthly, and monthly $\mathrm{Q}_{7,10}$. 


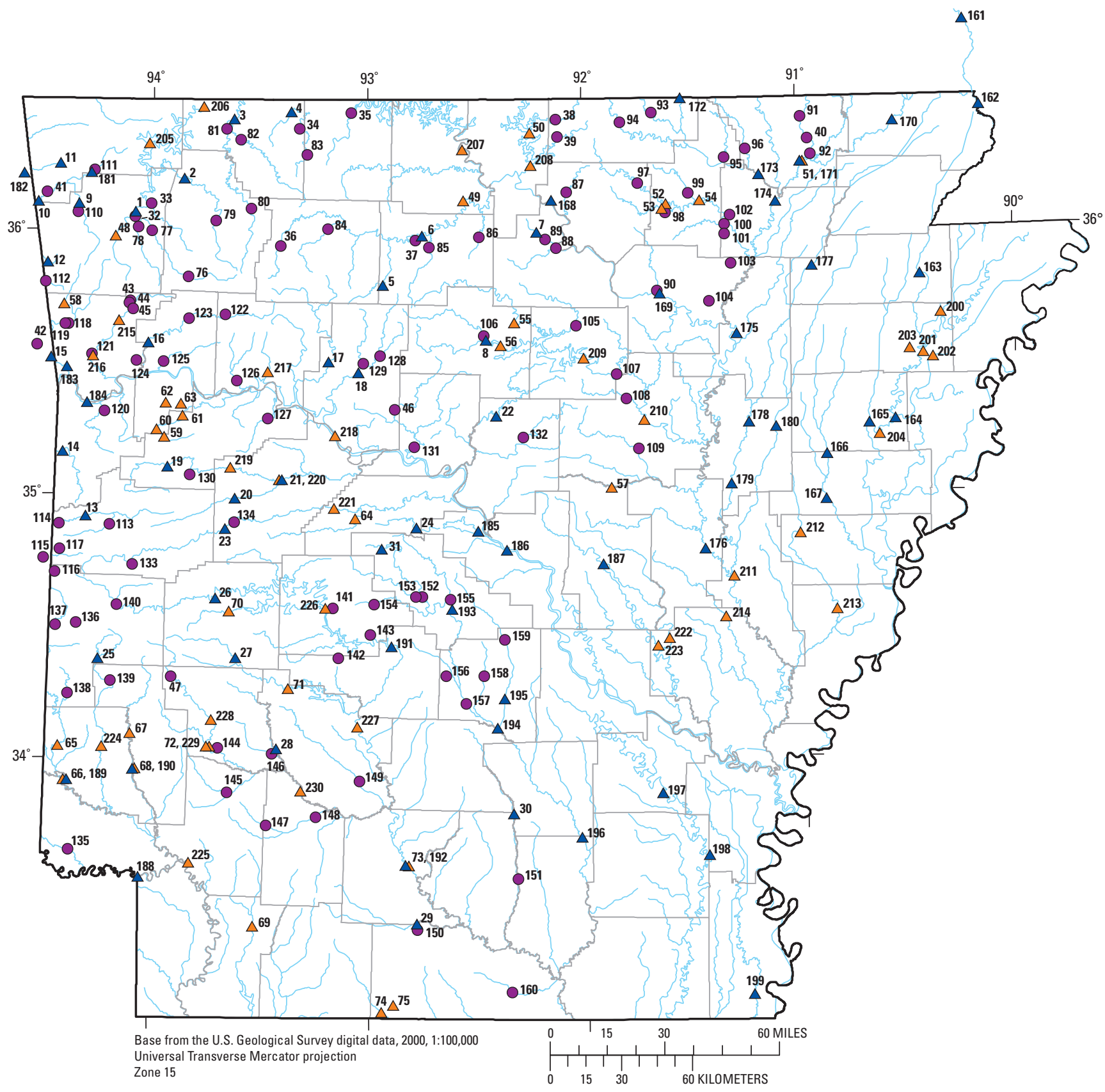

EXPLANATION

$\Delta^{11}$ Active continuous-streamflow record gaging station and identifier (table 1)

$\Delta^{48}$ Inactive continuous-streamflow record gaging station and identifier (table 1)

-41 Partial-record gaging station and identifier (table 1)

Figure 1. Continuous-streamflow record and partial-record gaging stations analyzed for low-flow characteristics. 
Table 1. Continuous streamflow-record and partial-record gaging stations analyzed for low-flow characteristics.

[ACR, active continuous record with minimal alterations in basin; SACR(PR), short-term active continuous record with minimal alterations in basin (analyzed and listed as partial-record stations); ICR, inactive continuous record with minimal alterations in basin; PR, partial record with minimal alterations in basin; HAACR, highly altered (numerous anthropogenic changes) active continuous record; HAICR, highly altered (numerous anthropogenic changes) inactive continuous record; stations listed twice had an ACR and a HAACR period of record analyzed]

\begin{tabular}{|c|c|c|c|c|c|}
\hline $\begin{array}{l}\text { Identifier } \\
\text { number } \\
\text { (figure 1, } \\
\text { plate 1) }\end{array}$ & $\begin{array}{l}\text { Station } \\
\text { number }\end{array}$ & Station name & $\begin{array}{c}\text { Latitude } \\
\text { (degrees and } \\
\text { decimal } \\
\text { degrees) }\end{array}$ & $\begin{array}{c}\text { Longitude } \\
\text { (degrees and } \\
\text { decimal } \\
\text { degrees) }\end{array}$ & Station type \\
\hline 1 & 07048600 & White River near Fayetteville, Ark. & 36.0730 & 94.0810 & ACR \\
\hline 2 & 07049000 & War Eagle Creek near Hindsville, Ark. & 36.2000 & 93.8550 & ACR \\
\hline 3 & 07050500 & Kings River near Berryville, Ark. & 36.4260 & 93.6230 & ACR \\
\hline 4 & 07053250 & Yocum Creek near Oak Grove, Ark. & 36.4540 & 93.3560 & ACR \\
\hline 5 & 07055875 & Richland Creek near Witts Spring, Ark. & 35.7970 & 92.9290 & ACR \\
\hline 6 & 07056000 & Buffalo River near St. Joe, Ark. & 35.9830 & 92.7480 & ACR \\
\hline 7 & 07060710 & $\begin{array}{l}\text { North Sylamore Creek near } \\
\text { Fifty-Six, Ark. }\end{array}$ & 35.9950 & 92.2130 & ACR \\
\hline 8 & 07075300 & $\begin{array}{l}\text { South Fork of Little Red River } \\
\text { at Clinton, Ark. }\end{array}$ & 35.5870 & 92.4520 & ACR \\
\hline 9 & 07194800 & Illinois River at Savoy, Ark. & 36.1030 & 94.3440 & ACR \\
\hline 10 & 07195430 & $\begin{array}{l}\text { Illinois River south of Siloam Springs, } \\
\text { Ark. }\end{array}$ & 36.1090 & 94.5340 & ACR \\
\hline 11 & 07195800 & Flint Creek at Springtown, Ark. & 36.2550 & 94.4340 & $\mathrm{ACR}$ \\
\hline 12 & 07196900 & Baron Fork at Dutch Mills, Ark. & 35.8800 & 94.4860 & ACR \\
\hline 13 & 07247000 & Poteau River at Cauthron, Ark. & 34.9190 & 94.2990 & $\mathrm{ACR}$ \\
\hline 14 & 07249400 & James Fork near Hackett, Ark. & 35.1630 & 94.4070 & $\mathrm{ACR}$ \\
\hline 15 & 07249985 & Lee Creek near Short, Okla. & 35.5190 & 94.4660 & ACR \\
\hline 16 & 07252000 & Mulberry River near Mulberry. Ark. & 35.5770 & 94.0160 & $\mathrm{ACR}$ \\
\hline 17 & 07257006 & $\begin{array}{l}\text { Big Piney Creek at Highway } 164 \text { near } \\
\text { Dover, Ark. }\end{array}$ & 35.5060 & 93.1810 & $\mathrm{ACR}$ \\
\hline 18 & 07257500 & Illinois Bayou near Scottsville, Ark. & 35.4660 & 93.0410 & ACR \\
\hline 19 & 07258500 & Petit Jean River near Booneville, Ark. & 35.1070 & 93.9240 & $\mathrm{ACR}$ \\
\hline 20 & 07260000 & Dutch Creek at Waltreak, Ark. & 34.8870 & 93.6130 & $\mathrm{ACR}$ \\
\hline $21^{1}$ & 07260500 & Petit Jean River at Danville, Ark. & 35.0590 & 93.3960 & $\mathrm{ACR}$ \\
\hline 22 & 07261000 & Cadron Creek near Guy, Ark. & 35.2990 & 92.4040 & ACR \\
\hline 23 & 07261500 & $\begin{array}{l}\text { Fourche LaFave River near } \\
\text { Gravelly, Ark. }\end{array}$ & 34.8730 & 93.6570 & $\mathrm{ACR}$ \\
\hline 24 & 07263295 & $\begin{array}{l}\text { Maumelle River at Williams } \\
\text { Junction, Ark. }\end{array}$ & 34.8760 & 92.7740 & ACR \\
\hline 25 & 07340300 & Cossatot River near Vandervoort, Ark. & 34.3790 & 94.2360 & ACR \\
\hline 26 & 07356000 & Ouachita River near Mount Ida, Ark. & 34.6100 & 93.6970 & ACR \\
\hline 27 & 07359610 & Caddo River near Caddo Gap, Ark. & 34.3830 & 93.6060 & ACR \\
\hline 28 & 07361500 & Antoine River at Antoine, Ark. & 34.0390 & 93.4180 & $\mathrm{ACR}$ \\
\hline 29 & 07362100 & Smackover Creek near Smackover, Ark. & 33.3760 & 92.7770 & $\mathrm{ACR}$ \\
\hline 30 & 07362500 & Moro Creek near Fordyce, Ark. & 33.7920 & 92.3330 & ACR \\
\hline 31 & 07362587 & $\begin{array}{l}\text { Alum Fork Saline River near } \\
\text { Reform, Ark. }\end{array}$ & 34.7970 & 92.9330 & ACR \\
\hline
\end{tabular}


Table 1. Continuous streamflow-record and partial-record gaging stations analyzed for low-flow characteristics.-Continued

$[\mathrm{ACR}$, active continuous record with minimal alterations in basin; SACR(PR), short-term active continuous record with minimal alterations in basin (analyzed and listed as partial-record stations); ICR, inactive continuous record with minimal alterations in basin; PR, partial record with minimal alterations in basin; HAACR, highly altered (numerous anthropogenic changes) active continuous record; HAICR, highly altered (numerous anthropogenic changes) inactive continuous record; stations listed twice had an ACR and a HAACR period of record analyzed]

\begin{tabular}{|c|c|c|c|c|c|}
\hline $\begin{array}{c}\text { Identifier } \\
\text { number } \\
\text { (figure 1, } \\
\text { plate 1) }\end{array}$ & $\begin{array}{l}\text { Station } \\
\text { number }\end{array}$ & Station name & $\begin{array}{c}\text { Latitude } \\
\text { (degrees and } \\
\text { decimal } \\
\text { degrees) }\end{array}$ & $\begin{array}{c}\text { Longitude } \\
\text { (degrees and } \\
\text { decimal } \\
\text { degrees) }\end{array}$ & Station type \\
\hline 32 & 07048550 & $\begin{array}{l}\text { West Fork White River east of } \\
\text { Fayetteville, Ark. }\end{array}$ & 36.0540 & 94.0830 & $\operatorname{SACR}(\mathrm{PR})$ \\
\hline 33 & 07048800 & Richland Creek at Goshen, Ark. & 36.1040 & 94.0080 & $\operatorname{SACR}(\mathrm{PR})$ \\
\hline 34 & 07053207 & Long Creek at Denver, Ark. & 36.3900 & 93.3170 & $\operatorname{SACR}(\mathrm{PR})$ \\
\hline 35 & 07054410 & Bear Creek near Omaha, Ark. & 36.4490 & 93.0750 & SACR(PR) \\
\hline 36 & 07055646 & Buffalo River near Boxley, Ark. & 35.9450 & 93.4030 & $\operatorname{SACR}(\mathrm{PR})$ \\
\hline 37 & 07055893 & Calf Creek near Silver Hill, Ark. & 35.9680 & 92.7760 & $\mathrm{SACR}(\mathrm{PR})$ \\
\hline 38 & 07058980 & Bennetts River at Vidette, Ark. & 36.4220 & 92.1190 & $\operatorname{SACR}(\mathrm{PR})$ \\
\hline 39 & 07059450 & Big Creek near Elizabeth, Ark. & 36.3570 & 92.1130 & $\operatorname{SACR}(\mathrm{PR})$ \\
\hline 40 & 07068890 & Fourche River above Pocahontas, Ark. & 36.3390 & 90.9420 & $\mathrm{SACR}(\mathrm{PR})$ \\
\hline 41 & 07195400 & $\begin{array}{l}\text { Illinois River at Hwy } 16 \text { near } \\
\text { Siloam Springs, Ark. }\end{array}$ & 36.1450 & 94.4940 & $\mathrm{SACR}(\mathrm{PR})$ \\
\hline 42 & 07249800 & Lee Creek at Short, Okla. & 35.5660 & 94.5320 & $\operatorname{SACR}(\mathrm{PR})$ \\
\hline 43 & 07250935 & Jones Creek at Winfrey, Ark. & 35.7360 & 94.1030 & SACR(PR) \\
\hline 44 & 07250965 & Frog Bayou near Winfrey, Ark. & 35.7270 & 94.1070 & $\operatorname{SACR}(\mathrm{PR})$ \\
\hline 45 & 07250974 & Jack Creek near Winfrey, Ark. & 35.7050 & 94.0890 & SACR(PR) \\
\hline 46 & 07260673 & $\begin{array}{l}\text { West Fork Point Remove Creek } \\
\text { near Hattieville, Ark. }\end{array}$ & 35.3250 & 92.8730 & $\operatorname{SACR}(\mathrm{PR})$ \\
\hline 47 & 07360200 & $\begin{array}{l}\text { Little Missouri River near } \\
\text { Langley, Ark. }\end{array}$ & 34.3110 & 93.8990 & $\operatorname{SACR}(\mathrm{PR})$ \\
\hline 48 & 07048000 & $\begin{array}{l}\text { West Fork White River at } \\
\text { Greenland, Ark. }\end{array}$ & 35.9830 & 94.1720 & ICR \\
\hline 49 & 07057000 & Buffalo River near Rush, Ark. & 36.1170 & 92.5540 & ICR \\
\hline 50 & 07059000 & North Fork River near Henderson, Ark. & 36.3720 & 92.2400 & ICR \\
\hline $51^{1}$ & 07069000 & Black River at Pocahontas, Ark. & 36.2540 & 90.9700 & ICR \\
\hline 52 & 07073000 & $\begin{array}{l}\text { Strawberry River near Evening Shade, } \\
\text { Ark. }\end{array}$ & 36.0990 & 91.6080 & ICR \\
\hline 53 & 07073500 & Piney Fork at Evening Shade, Ark. & 36.0810 & 91.6110 & ICR \\
\hline 54 & 07074000 & $\begin{array}{l}\text { Strawberry River near } \\
\text { Poughkeepsie, Ark. }\end{array}$ & 36.1100 & 91.4500 & ICR \\
\hline 55 & 07075000 & $\begin{array}{l}\text { Middle Fork Little Red River at Shirley, } \\
\text { Ark. }\end{array}$ & 35.6530 & 92.3190 & ICR \\
\hline 56 & 07075500 & $\begin{array}{l}\text { South Fork Little Red River near Clinton, } \\
\text { Ark. }\end{array}$ & 35.5670 & 92.3830 & ICR \\
\hline 57 & 07076850 & Cypress Bayou near Beebe, Ark. & 35.0250 & 91.8730 & ICR \\
\hline 58 & 07249500 & Cove Creek near Lee Creek, Ark. & 35.7220 & 94.4080 & ICR \\
\hline 59 & 07253000 & Sixmile Creek at Chismville, Ark. & 35.2210 & 93.9390 & ICR \\
\hline 60 & 07253500 & Sixmile Creek near Branch, Ark. & 35.2490 & 93.9740 & ICR \\
\hline 61 & 07255000 & Sixmile Creek at Caulksville, Ark. & 35.3010 & 93.8540 & ICR \\
\hline
\end{tabular}


Table 1. Continuous streamflow-record and partial-record gaging stations analyzed for low-flow characteristics.-Continued

[ACR, active continuous record with minimal alterations in basin; SACR(PR), short-term active continuous record with minimal alterations in basin (analyzed and listed as partial-record stations); ICR, inactive continuous record with minimal alterations in basin; PR, partial record with minimal alterations in basin; HAACR, highly altered (numerous anthropogenic changes) active continuous record; HAICR, highly altered (numerous anthropogenic changes) inactive continuous record; stations listed twice had an ACR and a HAACR period of record analyzed]

\begin{tabular}{|c|c|c|c|c|c|}
\hline $\begin{array}{c}\text { Identifier } \\
\text { number } \\
\text { (figure 1, } \\
\text { plate 1) }\end{array}$ & $\begin{array}{l}\text { Station } \\
\text { number }\end{array}$ & Station name & $\begin{array}{c}\text { Latitude } \\
\text { (degrees and } \\
\text { decimal } \\
\text { degrees) }\end{array}$ & $\begin{array}{l}\text { Longitude } \\
\text { (degrees and } \\
\text { decimal } \\
\text { degrees) }\end{array}$ & Station type \\
\hline 62 & 07255500 & Hurricane Creek near Branch, Ark. & 35.3510 & 93.9340 & ICR \\
\hline 63 & 07256000 & Hurricane Creek near Caulksville, Ark. & 35.3470 & 93.8630 & ICR \\
\hline 64 & 07263000 & $\begin{array}{l}\text { South Fourche LaFave River near Hollis, } \\
\text { Ark. }\end{array}$ & 34.9110 & 93.0560 & ICR \\
\hline 65 & 07339500 & Rolling Fork near DeQueen, Ark. & 34.0470 & 94.4130 & ICR \\
\hline $66^{1}$ & 07340000 & Little River near Horatio, Ark. & 33.9190 & 94.3870 & ICR \\
\hline 67 & 07341000 & Saline River near Dierks, Ark. & 34.0960 & 94.0840 & ICR \\
\hline $68^{1}$ & 07341200 & Saline River near Lockesburg, Ark. & 33.9623 & 94.0616 & ICR \\
\hline 69 & 07349430 & Bodcau Creek at Stamps, Ark. & 33.3670 & 93.5220 & ICR \\
\hline 70 & 07356500 & $\begin{array}{l}\text { South Fork Ouachita River at } \\
\text { Mount Ida, Ark. }\end{array}$ & 34.5600 & 93.6360 & ICR \\
\hline 71 & 07359800 & Caddo River near Alpine, Ark. & 34.2670 & 93.3620 & ICR \\
\hline $72^{1}$ & 07361000 & $\begin{array}{l}\text { Little Missouri River near } \\
\text { Murfreesboro, Ark. }\end{array}$ & 34.0490 & 93.7200 & ICR \\
\hline $73^{1}$ & 07362000 & Ouachita River at Camden, Ark. & 33.5960 & 92.8180 & ICR \\
\hline 74 & 07365800 & Cornie Bayou near Three Creeks, Ark. & 33.0390 & 92.9380 & ICR \\
\hline 75 & 07365900 & Three Creeks near Three Creeks, Ark. & 33.0670 & 92.8840 & ICR \\
\hline 76 & 07047976 & White River at Combs, Ark. & 35.8280 & 93.8320 & PR \\
\hline 77 & 07047980 & White River at Elkins, Ark. & 36.0010 & 94.0040 & PR \\
\hline 78 & 07047985 & $\begin{array}{l}\text { Middle Fork White River near } \\
\text { Fayetteville, Ark. }\end{array}$ & 36.0160 & 94.0660 & PR \\
\hline 79 & 07048960 & War Eagle Creek near Huntsville, Ark. & 36.0420 & 93.7050 & PR \\
\hline 80 & 07050225 & Kings River near Kingston, Ark. & 36.0880 & 93.5420 & PR \\
\hline 81 & 07050250 & Kings River near Pleasant Valley, Ark. & 36.3890 & 93.6590 & PR \\
\hline 82 & 07050390 & $\begin{array}{l}\text { Osage Creek southwest of } \\
\text { Berryville, Ark. }\end{array}$ & 36.3490 & 93.5910 & PR \\
\hline 83 & 07053200 & Long Creek at Alpena, Ark. & 36.2920 & 93.2820 & PR \\
\hline 84 & 07055700 & $\begin{array}{l}\text { Little Buffalo River near } \\
\text { Jasper, Ark. }\end{array}$ & 36.0100 & 93.1840 & PR \\
\hline 85 & 07056510 & Bear Creek near Marshall, Ark. & 35.9410 & 92.7130 & PR \\
\hline 86 & 07057100 & Big Creek near Big Flat, Ark. & 35.9790 & 92.4810 & PR \\
\hline 87 & 07060520 & Piney Creek near Calico Rock, Ark. & 36.1470 & 92.0710 & PR \\
\hline 88 & 07060700 & South Sylamore Creek at Allison, Ark. & 35.9360 & 92.1210 & PR \\
\hline 89 & 07060720 & North Sylamore Creek near Allison, Ark. & 35.9680 & 92.1710 & PR \\
\hline 90 & 07060900 & Polk Bayou at Batesville, Ark. & 35.7710 & 91.6550 & PR \\
\hline 91 & 07068880 & Mud Creek near Ingram, Ark. & 36.4230 & 90.9750 & PR \\
\hline 92 & 07068900 & Fourche River near Pocahontas, Ark. & 36.2810 & 90.9290 & PR \\
\hline 93 & 07069265 & Myatt Creek near Salem, Ark. & 36.4440 & 91.6700 & PR \\
\hline
\end{tabular}


Table 1. Continuous streamflow-record and partial-record gaging stations analyzed for low-flow characteristics.-Continued

$[\mathrm{ACR}$, active continuous record with minimal alterations in basin; SACR(PR), short-term active continuous record with minimal alterations in basin (analyzed and listed as partial-record stations); ICR, inactive continuous record with minimal alterations in basin; PR, partial record with minimal alterations in basin; HAACR, highly altered (numerous anthropogenic changes) active continuous record; HAICR, highly altered (numerous anthropogenic changes) inactive continuous record; stations listed twice had an ACR and a HAACR period of record analyzed]

\begin{tabular}{|c|c|c|c|c|c|}
\hline $\begin{array}{c}\text { Identifier } \\
\text { number } \\
\text { (figure 1, } \\
\text { plate 1) }\end{array}$ & $\begin{array}{l}\text { Station } \\
\text { number }\end{array}$ & Station name & $\begin{array}{c}\text { Latitude } \\
\text { (degrees and } \\
\text { decimal } \\
\text { degrees) }\end{array}$ & $\begin{array}{c}\text { Longitude } \\
\text { (degrees and } \\
\text { decimal } \\
\text { degrees) }\end{array}$ & Station type \\
\hline 94 & 07069270 & South Fork Spring River near Salem, Ark. & 36.4090 & 91.8180 & PR \\
\hline 95 & 07069350 & Martins Creek near Williford, Ark. & 36.2730 & 91.3330 & PR \\
\hline 96 & 07069400 & Janes Creek at Ravenden Springs, Ark. & 36.3030 & 91.2330 & PR \\
\hline 97 & 07072900 & Strawberry River near Franklin, Ark. & 36.1780 & 91.7390 & PR \\
\hline 98 & 07073600 & Mill Creek at Evening Shade, Ark. & 36.0660 & 91.6100 & PR \\
\hline 99 & 07073995 & $\begin{array}{l}\text { North Big Creek near Evening Shade, } \\
\text { Ark. }\end{array}$ & 36.1380 & 91.5030 & PR \\
\hline 100 & 07074248 & South Big Creek near Strawberry, Ark. & 36.0200 & 91.3360 & PR \\
\hline 101 & 07074250 & Reeds Creek near Strawberry, Ark. & 35.9830 & 91.3370 & PR \\
\hline 102 & 07074260 & Cooper Creek near Smithville, Ark. & 36.0530 & 91.3100 & PR \\
\hline 103 & 07074400 & Curia Creek near Dowdy, Ark. & 35.8710 & 91.3100 & PR \\
\hline 104 & 07074450 & Dota Creek near Newark, Ark. & 35.7290 & 91.4140 & PR \\
\hline 105 & 07075200 & $\begin{array}{l}\text { Devils Fork Little Red River near } \\
\text { Brownsville, Ark. }\end{array}$ & 35.6390 & 92.0320 & PR \\
\hline 106 & 07075390 & Archey Creek at Clinton, Ark. & 35.6040 & 92.4600 & PR \\
\hline 107 & 07076510 & Big Creek near Pangburn, Ark. & 35.4560 & 91.8450 & PR \\
\hline 108 & 07076530 & Big Creek near Letona, Ark. & 35.3620 & 91.8010 & PR \\
\hline 109 & 07076800 & Bayou Des Arc near Garner, Ark. & 35.1720 & 91.7460 & PR \\
\hline 110 & 07194790 & $\begin{array}{l}\text { Muddy Fork Illinois River near Savoy, } \\
\text { Ark. }\end{array}$ & 36.0700 & 94.3480 & PR \\
\hline 111 & 07194950 & $\begin{array}{l}\text { Little Osage Creek near Healing Springs, } \\
\text { Ark. }\end{array}$ & 36.2330 & 94.2770 & PR \\
\hline 112 & 07196950 & Evansville Creek at Evansville, Ark. & 35.8060 & 94.4960 & PR \\
\hline 113 & 07246970 & Jones Creek near Waldron, Ark. & 34.8870 & 94.1880 & PR \\
\hline 114 & 07247010 & Poteau River near Bates, Ark. & 34.8890 & 94.4200 & PR \\
\hline 115 & 07247100 & Black Fork near Page, Okla & 34.7600 & 94.4900 & PR \\
\hline 116 & 07247200 & Big Creek at Howard, Ark. & 34.7070 & 94.4370 & PR \\
\hline 117 & 07247300 & Haws Creek near Black Fork, Ark. & 34.7930 & 94.4160 & PR \\
\hline 118 & 07249600 & Lee Creek at Natural Dam, Ark. & 35.6460 & 94.3940 & PR \\
\hline 119 & 07249700 & $\begin{array}{l}\text { Mountain Fork Creek at Natural Dam, } \\
\text { Ark. }\end{array}$ & 35.6450 & 94.3970 & PR \\
\hline 120 & 07250600 & Vache Grasse Creek near Lavaca, Ark. & 35.3180 & 94.2150 & PR \\
\hline 121 & 07251400 & Cedar Creek near Rudy, Ark. & 35.5290 & 94.2780 & PR \\
\hline 122 & 07251800 & $\begin{array}{l}\text { Little Mulberry Creek near } \\
\text { Oark, Ark. }\end{array}$ & 35.6860 & 93.6600 & PR \\
\hline 123 & 07251900 & Mulberry River near Cass, Ark. & 35.6690 & 93.8290 & PR \\
\hline 124 & 07252100 & $\begin{array}{l}\text { Little Mulberry Creek near } \\
\text { Mulberry, Ark. }\end{array}$ & 35.5100 & 94.0710 & PR \\
\hline
\end{tabular}


Table 1. Continuous streamflow-record and partial-record gaging stations analyzed for low-flow characteristics.-Continued

[ACR, active continuous record with minimal alterations in basin; SACR(PR), short-term active continuous record with minimal alterations in basin (analyzed and listed as partial-record stations); ICR, inactive continuous record with minimal alterations in basin; PR, partial record with minimal alterations in basin; HAACR, highly altered (numerous anthropogenic changes) active continuous record; HAICR, highly altered (numerous anthropogenic changes) inactive continuous record; stations listed twice had an ACR and a HAACR period of record analyzed]

\begin{tabular}{|c|c|c|c|c|c|}
\hline $\begin{array}{l}\text { Identifier } \\
\text { number } \\
\text { (figure 1, } \\
\text { plate 1) }\end{array}$ & $\begin{array}{l}\text { Station } \\
\text { number }\end{array}$ & Station name & $\begin{array}{c}\text { Latitude } \\
\text { (degrees and } \\
\text { decimal } \\
\text { degrees) }\end{array}$ & $\begin{array}{l}\text { Longitude } \\
\text { (degrees and } \\
\text { decimal } \\
\text { degrees) }\end{array}$ & Station type \\
\hline 125 & 07252300 & White Oak Creek near Ozark, Ark. & 35.5070 & 93.9460 & PR \\
\hline 126 & 07256200 & Horsehead Creek at Hartman, Ark. & 35.4350 & 93.6060 & PR \\
\hline 127 & 07256700 & Big Shoal Creek near New Blaine, Ark. & 35.2920 & 93.4600 & PR \\
\hline 128 & 07257470 & $\begin{array}{l}\text { Middle Fork Illinois Bayou near Hector, } \\
\text { Ark. }\end{array}$ & 35.5280 & 92.9410 & PR \\
\hline 129 & 07257480 & $\begin{array}{l}\text { North Fork Illinois Bayou near Scotts- } \\
\text { ville, Ark. }\end{array}$ & 35.5000 & 93.0190 & PR \\
\hline 130 & 07258700 & Sugar Creek near Sugar Grove, Ark. & 35.0770 & 93.8190 & PR \\
\hline 131 & 07260700 & Point Remove Creek near Morrilton, Ark. & 35.1820 & 92.7840 & PR \\
\hline 132 & 07261200 & East Fork Cadron Creek near Enola, Ark. & 35.2180 & 92.2790 & PR \\
\hline 133 & 07261400 & Mill Creek near Boles, Ark. & 34.7370 & 94.0800 & PR \\
\hline 134 & 07261600 & Gafford Creek near Bluffton, Ark. & 34.8980 & 93.6120 & PR \\
\hline 135 & 07336900 & Walnut Bayou near Foreman, Ark. & 33.6540 & 94.3590 & PR \\
\hline 136 & 07338700 & Twomile Creek near Hatfield, Ark. & 34.5140 & 94.3370 & PR \\
\hline 137 & 07338720 & Mountain Fork near Hatfield, Ark. & 34.5050 & 94.4310 & PR \\
\hline 138 & 07339200 & Rolling Fork near Grannis, Ark. & 34.2470 & 94.3730 & PR \\
\hline 139 & 07340400 & Cossatot River near Umpire, Ark. & 34.2960 & 94.1770 & PR \\
\hline 140 & 07355810 & Ouachita River near Mena, Ark. & 34.5840 & 94.1520 & PR \\
\hline 141 & 07357710 & $\begin{array}{l}\text { Glazypeau Creek at Mountain } \\
\text { Pine, Ark. }\end{array}$ & 34.5720 & 93.1590 & PR \\
\hline 142 & 07358010 & $\begin{array}{l}\text { Fourche A Loupe Creek near Hot } \\
\text { Springs, Ark. }\end{array}$ & 34.3830 & 93.1330 & PR \\
\hline 143 & 07358700 & Gulpha Creek near Hot Springs, Ark. & 34.4710 & 92.9860 & PR \\
\hline 144 & 07361025 & Prairie Creek near Murfreesboro, Ark. & 34.0430 & 93.6840 & PR \\
\hline 145 & 07361160 & $\begin{array}{l}\text { North Fork Ozan Creek near } \\
\text { McCaskill, Ark. }\end{array}$ & 33.8730 & 93.6420 & PR \\
\hline 146 & 07361540 & Wolf Creek near Antoine, Ark. & 34.0200 & 93.4380 & PR \\
\hline 147 & 07361640 & $\begin{array}{l}\text { Little Terre Rouge Creek near } \\
\text { Emmet, Ark. }\end{array}$ & 33.7490 & 93.4630 & PR \\
\hline 148 & 07361650 & Terre Rouge Creek near Prescott, Ark. & 33.7790 & 93.2360 & PR \\
\hline 149 & 07361800 & Terre Noire Creek near Gurdon, Ark. & 33.9170 & 93.0360 & PR \\
\hline 150 & 07362090 & Camp Creek near Smackover, Ark. & 33.3530 & 92.7740 & PR \\
\hline 151 & 07362550 & Moro Creek near Banks, Ark. & 33.5440 & 92.3170 & PR \\
\hline 152 & 07362600 & $\begin{array}{l}\text { Alum Fork Saline River at } \\
\text { Crows, Ark. }\end{array}$ & 34.6160 & 92.7490 & PR \\
\hline 153 & 07362700 & $\begin{array}{l}\text { Middle Fork Saline River at } \\
\text { Crows, Ark. }\end{array}$ & 34.6150 & 92.7790 & PR \\
\hline 154 & 07362800 & $\begin{array}{l}\text { South Fork Saline River near Hot } \\
\text { Springs, Ark. }\end{array}$ & 34.5860 & 92.9700 & PR \\
\hline
\end{tabular}


Table 1. Continuous streamflow-record and partial-record gaging stations analyzed for low-flow characteristics.-Continued

$[\mathrm{ACR}$, active continuous record with minimal alterations in basin; SACR(PR), short-term active continuous record with minimal alterations in basin (analyzed and listed as partial-record stations); ICR, inactive continuous record with minimal alterations in basin; PR, partial record with minimal alterations in basin; HAACR, highly altered (numerous anthropogenic changes) active continuous record; HAICR, highly altered (numerous anthropogenic changes) inactive continuous record; stations listed twice had an ACR and a HAACR period of record analyzed]

\begin{tabular}{|c|c|c|c|c|c|}
\hline $\begin{array}{c}\text { Identifier } \\
\text { number } \\
\text { (figure 1, } \\
\text { plate 1) }\end{array}$ & $\begin{array}{l}\text { Station } \\
\text { number }\end{array}$ & Station name & $\begin{array}{c}\text { Latitude } \\
\text { (degrees and } \\
\text { decimal } \\
\text { degrees) }\end{array}$ & $\begin{array}{l}\text { Longitude } \\
\text { (degrees and } \\
\text { decimal } \\
\text { degrees) }\end{array}$ & Station type \\
\hline 155 & 07362900 & $\begin{array}{l}\text { North Fork Saline River near } \\
\text { Benton, Ark. }\end{array}$ & 34.6050 & 92.6190 & PR \\
\hline 156 & 07363110 & Big Creek at Poyen, Ark. & 34.3140 & 92.6400 & PR \\
\hline 157 & 07363160 & Saline River near Leola, Ark. & 34.2100 & 92.5480 & PR \\
\hline 158 & 07363180 & Lost Creek near Sheridan, Ark. & 34.3140 & 92.4660 & PR \\
\hline 159 & 07363276 & Hurricane Creek near Ico, Ark. & 34.4510 & 92.3720 & PR \\
\hline 160 & 07364060 & Bayou Lapile at Strong, Ark. & 33.1150 & 92.3460 & PR \\
\hline 161 & 07040000 & St. Francis River at Fisk, Mo. & 36.7810 & 90.2020 & HAACR \\
\hline 162 & 07040100 & St. Francis River at St. Francis, Ark. & 36.4560 & 90.1370 & HAACR \\
\hline 163 & 07040450 & St. Francis River at Lake City, Ark. & 35.8210 & 90.4320 & HAACR \\
\hline 164 & 07047800 & St. Francis River at Parkin, Ark. & 35.2730 & 90.5590 & HAACR \\
\hline 165 & 07047900 & St. Francis Bay at Riverfront, Ark. & 35.2590 & 90.6800 & HAACR \\
\hline 166 & 07047942 & L'Anguille River near Colt, Ark. & 35.1440 & 90.8780 & HAACR \\
\hline 167 & 07047950 & L'Anguille River at Palestine, Ark. & 34.9730 & 90.8850 & HAACR \\
\hline 168 & 07060500 & White River at Calico Rock, Ark. & 36.1160 & 92.1430 & HAACR \\
\hline 169 & 07061000 & White River at Batesville, Ark. & 35.7600 & 91.6410 & HAACR \\
\hline 170 & 07064000 & Black River near Corning, Ark. & 36.4020 & 90.5410 & HAACR \\
\hline $171^{1}$ & 07069000 & Black River at Pocahontas, Ark. & 36.2540 & 90.9700 & HAACR \\
\hline 172 & 07069190 & $\begin{array}{l}\text { Mammoth Spring at Mammoth Spring, } \\
\text { Ark. }\end{array}$ & 36.4980 & 91.5360 & HAACR \\
\hline 173 & 07069500 & Spring River at Imboden, Ark. & 36.2050 & 91.1720 & HAACR \\
\hline 174 & 07072500 & Black River at Black Rock, Ark. & 36.1040 & 91.0970 & HAACR \\
\hline 175 & 07074500 & White River at Newport, Ark. & 35.6050 & 91.2870 & HAACR \\
\hline 176 & 07077000 & White River at DeValls Bluff, Ark. & 34.7900 & 91.4460 & HAACR \\
\hline 177 & 07077380 & Cache River at Egypt, Ark. & 35.8580 & 90.9330 & HAACR \\
\hline 178 & 07077500 & Cache River at Patterson, Ark. & 35.2690 & 91.2370 & HAACR \\
\hline 179 & 07077555 & Cache River near Cotton Plant, Ark. & 35.0350 & 91.3220 & HAACR \\
\hline 180 & 07077700 & Bayou DeView near Morton, Ark. & 35.2520 & 91.1100 & HAACR \\
\hline 181 & 07195000 & Osage Creek near Elm Springs, Ark. & 36.2219 & 94.2883 & HAACR \\
\hline 182 & 07195855 & $\begin{array}{l}\text { Flint Creek near West Siloam Springs, } \\
\text { Ark. }\end{array}$ & 36.2161 & 94.6042 & HAACR \\
\hline 183 & 07250085 & $\begin{array}{l}\text { Lee Creek at Lee Creek Reservoir near } \\
\text { Van Buren, Ark. }\end{array}$ & 35.4840 & 94.3930 & HAACR \\
\hline 184 & 07250550 & $\begin{array}{l}\text { Arkansas River at James W. Trimble } \\
\text { Lock \& Dam near Van Buren, Ark. }\end{array}$ & 35.3490 & 94.2980 & HAACR \\
\hline 185 & 07263300 & $\begin{array}{l}\text { Maumelle River at Maumelle Dam at } \\
\text { Natural Steps, Ark. }\end{array}$ & 34.8640 & 92.4890 & HAACR \\
\hline
\end{tabular}


Table 1. Continuous streamflow-record and partial-record gaging stations analyzed for low-flow characteristics.-Continued

[ACR, active continuous record with minimal alterations in basin; SACR(PR), short-term active continuous record with minimal alterations in basin (analyzed and listed as partial-record stations); ICR, inactive continuous record with minimal alterations in basin; PR, partial record with minimal alterations in basin; HAACR, highly altered (numerous anthropogenic changes) active continuous record; HAICR, highly altered (numerous anthropogenic changes) inactive continuous record; stations listed twice had an ACR and a HAACR period of record analyzed]

\begin{tabular}{|c|c|c|c|c|c|}
\hline $\begin{array}{c}\text { Identifier } \\
\text { number } \\
\text { (figure 1, } \\
\text { plate 1) }\end{array}$ & $\begin{array}{l}\text { Station } \\
\text { number }\end{array}$ & Station name & $\begin{array}{c}\text { Latitude } \\
\text { (degrees and } \\
\text { decimal } \\
\text { degrees) }\end{array}$ & $\begin{array}{c}\text { Longitude } \\
\text { (degrees and } \\
\text { decimal } \\
\text { degrees) }\end{array}$ & Station type \\
\hline 186 & 07263450 & $\begin{array}{l}\text { Arkansas River at Murray Dam near } \\
\text { Little Rock, Ark. }\end{array}$ & 34.7910 & 92.3590 & HAACR \\
\hline 187 & 07264000 & Bayou Meto near Lonoke, Ark. & 34.7370 & 91.9160 & HAACR \\
\hline 188 & 07337000 & Red River at Index, Ark. & 33.5520 & 94.0410 & HAACR \\
\hline $189^{1}$ & 07340000 & Little River near Horatio, Ark. & 33.9190 & 94.3870 & HAACR \\
\hline $190^{1}$ & 07341200 & Saline River near Lockesburg, Ark. & 33.9620 & 94.0610 & HAACR \\
\hline 191 & 07359002 & $\begin{array}{l}\text { Ouachita River at Remmel Dam above } \\
\text { Jones Mill, Ark. }\end{array}$ & 34.4260 & 92.8910 & HAACR \\
\hline $192^{1}$ & 07362000 & Ouachita River at Camden, Ark. & 33.5960 & 92.8180 & HAACR \\
\hline 193 & 07363000 & Saline River at Benton, Ark. & 34.5680 & 92.6110 & HAACR \\
\hline 194 & 07363200 & Saline River near Sheridan, Ark. & 34.1150 & 92.4060 & HAACR \\
\hline 195 & 07363400 & Hurricane Creek below Sheridan, Ark. & 34.2280 & 92.3720 & HAACR \\
\hline 196 & 07363500 & Saline River near Rye, Ark. & 33.7010 & 92.0260 & HAACR \\
\hline 197 & 07364133 & $\begin{array}{l}\text { Bayou Bartholomew at Garrett Bridge, } \\
\text { Ark. }\end{array}$ & 33.8664 & 91.6561 & HAACR \\
\hline 198 & 07364150 & $\begin{array}{l}\text { Bayou Bartholomew near } \\
\text { McGehee, Ark. }\end{array}$ & 33.6280 & 91.4460 & HAACR \\
\hline 199 & 07369680 & Bayou Macon at Eudora, Ark. & 33.1000 & 91.2530 & HAACR \\
\hline 200 & 07046600 & $\begin{array}{l}\text { Right Hand Chute of Little River } \\
\text { at Rivervale, Ark. }\end{array}$ & 35.6720 & 90.3380 & HAICR \\
\hline 201 & 07047500 & St. Francis River at Marked Tree, Ark. & 35.5220 & 90.4240 & HAICR \\
\hline 202 & 07047600 & Tyronza River near Tyronza, Ark. & 35.5050 & 90.3800 & HAICR \\
\hline 203 & 07047810 & $\begin{array}{l}\text { St. Francis River Floodway near Marked } \\
\text { Tree, Ark. }\end{array}$ & 35.5380 & 90.4850 & HAICR \\
\hline 204 & 07047902 & $\begin{array}{l}\text { St. Francis River at Latitude of } \\
\text { Wittsburg, Ark. }\end{array}$ & 35.2170 & 90.6330 & HAICR \\
\hline 205 & 07049500 & $\begin{array}{l}\text { Beaver Lake at Highway } 12 \text { bridge near } \\
\text { Rogers, Ark. }\end{array}$ & 36.3320 & 94.0190 & HAICR \\
\hline 206 & 07050000 & White River at Beaver Ark. & 36.4720 & 93.7650 & HAICR \\
\hline 207 & 07055000 & White River near Flippin, Ark. & 36.3100 & 92.5580 & HAICR \\
\hline 208 & 07060000 & $\begin{array}{l}\text { North Fork River at Norfork Dam near } \\
\text { Norfork, Ark. }\end{array}$ & 36.2490 & 92.2380 & HAICR \\
\hline 209 & 07076000 & Little Red River near Heber Springs, Ark. & 35.5170 & 91.9970 & HAICR \\
\hline 210 & 07076620 & Little Red River near Searcy, Ark. & 35.2820 & 91.7190 & HAICR \\
\hline 211 & 07077800 & White River at Clarendon, Ark. & 34.6860 & 91.3150 & HAICR \\
\hline 212 & 07077930 & Big Creek near Moro, Ark. & 34.8470 & 91.0100 & HAICR \\
\hline 213 & 07077950 & Big Creek at Popular Grove, Ark. & 34.5560 & 90.8460 & HAICR \\
\hline 214 & 07078000 & LaGrue Bayou near Stuttgart, Ark. & 34.5320 & 91.3560 & HAICR \\
\hline 215 & 07251000 & Frog Bayou near Mountainburg, Ark. & 35.6611 & 94.1528 & HAICR \\
\hline
\end{tabular}


Table 1. Continuous streamflow-record and partial-record gaging stations analyzed for low-flow characteristics.-Continued

$[\mathrm{ACR}$, active continuous record with minimal alterations in basin; SACR(PR), short-term active continuous record with minimal alterations in basin (analyzed and listed as partial-record stations); ICR, inactive continuous record with minimal alterations in basin; PR, partial record with minimal alterations in basin; HAACR, highly altered (numerous anthropogenic changes) active continuous record; HAICR, highly altered (numerous anthropogenic changes) inactive continuous record; stations listed twice had an ACR and a HAACR period of record analyzed]

\begin{tabular}{|c|c|c|c|c|c|}
\hline $\begin{array}{c}\text { Identifier } \\
\text { number } \\
\text { (figure 1, } \\
\text { plate 1) }\end{array}$ & $\begin{array}{l}\text { Station } \\
\text { number }\end{array}$ & Station name & $\begin{array}{c}\text { Latitude } \\
\text { (degrees and } \\
\text { decimal } \\
\text { degrees) }\end{array}$ & $\begin{array}{c}\text { Longitude } \\
\text { (degrees and } \\
\text { decimal } \\
\text { degrees) }\end{array}$ & Station type \\
\hline 216 & 07251500 & Frog Bayou at Rudy, Ark. & 35.5256 & 94.2717 & HAICR \\
\hline 217 & 07256500 & Spadra Creek at Clarksville, Ark. & 35.4680 & 93.4630 & HAICR \\
\hline 218 & 07258000 & Arkansas River at Dardanelle, Ark. & 35.2260 & 93.1490 & HAICR \\
\hline 219 & 07259500 & Petit Jean River near Waveland, Ark. & 35.1047 & 93.6314 & HAICR \\
\hline $220^{1}$ & 07260500 & Petit Jean River at Danville, Ark. & 35.0590 & 93.3960 & HAICR \\
\hline 221 & 07262500 & Fourche LaFave River near Nimrod, Ark. & 34.9506 & 93.1544 & HAICR \\
\hline 222 & 07264500 & Bayou Meto near Stuttgart, Ark. & 34.4540 & 91.6160 & HAICR \\
\hline 223 & 07265000 & Crooked Creek near Humphrey, Ark. & 34.4260 & 91.6680 & HAICR \\
\hline 224 & 07340500 & Cossatot River near DeQueen, Ark. & 34.0460 & 94.2120 & HAICR \\
\hline 225 & 07341500 & Red River at Fulton, Ark. & 33.6070 & 93.8140 & HAICR \\
\hline 226 & 07357501 & $\begin{array}{l}\text { Ouachita River at Blakely Mountain Dam } \\
\text { near Hot Springs, Ark. }\end{array}$ & 34.5720 & 93.1940 & HAICR \\
\hline 227 & 07360000 & Ouachita River at Arkadelphia, Ark. & 34.1210 & 93.0460 & HAICR \\
\hline 228 & 07360501 & $\begin{array}{l}\text { Little Missouri River at Narrows Dam } \\
\text { near Murfreesboro, Ark. }\end{array}$ & 34.1480 & 93.7150 & HAICR \\
\hline $229^{1}$ & 07361000 & $\begin{array}{l}\text { Little Missouri River near } \\
\text { Murfreesboro, Ark. }\end{array}$ & 34.0490 & 93.7200 & HAICR \\
\hline 230 & 07361600 & $\begin{array}{l}\text { Little Missouri River near } \\
\text { Boughton, Ark. }\end{array}$ & 33.8780 & 93.3040 & HAICR \\
\hline
\end{tabular}

\footnotetext{
${ }^{1}$ A site analyzed as ICR and HAACR station type.
} 


\section{Previous Studies}

This report is the sixth in a series of reports dealing with low-flow characteristics of Arkansas streams. The first report by Hines (1965) contained information on low-flow frequency and flow duration for unregulated sites. The second report (Hines, 1975) contained updated low-flow characteristics for regulated and unregulated streams. Hunrichs (1983) identified perennial streams in most areas of Arkansas based on a range of $\mathrm{Q}_{7,10}$. Streams with $\mathrm{Q}_{7,10}$ above zero were considered to be perennial. Ludwig (1992) updated the low-flow characteristics for all of the streamflow gaging stations included in Hines (1975) with streamflow data collected through 1990. Ludwig and Tasker (1993) used an ordinary least squares (OLS) logistic regression and multiple linear regression model with a generalized least squares parameter estimation procedure to estimate the $\mathrm{Q}_{7,2}$ and $\mathrm{Q}_{7,10}$ at ungaged streams in Arkansas.

\section{Continuous-Streamflow Record Gaging Network}

Data used in this report were collected at 129 active and inactive continuous-streamflow gaging stations and 101 partial-record gaging stations. A continuous-streamflow gaging station is a gaging station on a stream where gage height is recorded continuously and for which daily mean discharge is computed. A partial-record station is a station on a stream where selected hydrologic data, such as discharge measurements, are collected periodically.

In 2005, the entire daily-discharge data network consisted of 216 active and inactive continuous-streamflow record gaging stations. Collection of daily-discharge data began in Arkansas in 1903 at the Ouachita River near Malvern. By 1939, daily-discharge data were collected at 64 gaging stations. In 2005, 85 (39 percent) of the 216 active and inactive continuous-streamflow record gaging stations had 30 or more years of record, and 100 sites (46 percent) of the active and inactive continuous-record streamflow gaging stations had 20 or more years of record.

\section{Methods of Analysis at Gaging Stations}

Streamflow is a continuous process varying over time. Basins can undergo natural variations in streamflow because of climatic changes and also non-natural alterations, such as withdrawals for water supply, reservoirs and dams, inputs from wastewater-treatment plants, and urbanization.

For this study, 70 active continuous-streamflow record (31 minimally altered and 39 highly altered), 59 inactive continuous-streamflow record (28 minimally altered and 31 highly altered), 16 short-term active continuous record (analyzed and listed as partial-record stations), and 85 partial- record stations (fig. 1, table 1) were used in the analysis. To be of use, the streamflow data collected at these sites were analyzed and discretized into daily, monthly, bimonthly, and annual time periods. For this low-flow study, the entire period of record of mean-daily streamflows for the minimally altered active continuous-streamflow record stations was investigated. For highly altered (numerous anthropogenic alterations, such as input from sewage-treatment plants or basins with numerous dams and reservoirs) stations with a minimum of 10 years of minimally altered continuous-streamflow record, a separate analysis was performed for the minimally altered and the highly altered periods of record. For highly altered sites with less than 10 years of minimally altered continuous-streamflow record, an analysis was performed on the highly altered period of record only. Mean-daily discharge is the arithmetic mean of the individual daily-mean discharges for the designated period, usually the entire period of record.

The low-flow characteristics calculated from streamflows generated from minimally altered basins at the sites described above were analyzed and used to determine the coefficients of the regression models to estimate low-flow characteristics for streams in ungaged basins. The minimally altered periods of the highly altered sites were not used in the regression models. Only continuous-streamflow record-gaging stations in minimally altered basins, active and inactive, with 10 or more years of streamflow record and drainage areas of less than 1,000 square miles $\left(\mathrm{mi}^{2}\right)$ were included in the analysis. This criterion for drainage area was applied to basins to minimize the potential undocumented alterations, such as urbanization, within the basin. Partial-record stations were classified as stations located in minimally altered basins that had less than 10 years of continuous-streamflow record or stations that had at least six sporadic low-flow discharge measurements and drainage areas of less than $1,000 \mathrm{mi}^{2}$.

\section{Low-Flow Frequency}

To compute return period low-flow values at continuousstreamflow record gaging stations, such as the $\mathrm{Q}_{7,10}$, a lowflow frequency analysis was performed. For the frequency analysis, an annual time series of the averaged consecutive 7-day minimum discharges (Riggs, 1972) was calculated for every continuous-streamflow record gaging station. The annual period is defined as the climatic year (April 1 through March 31). Typically, the climatic year is used for low-flow analyses because the low-flow events fall within the middle of this time span. For this study, the climatic year was used for calculation of all annual $\mathrm{Q}_{7}$ series values.

\section{Calculation of Low-Flow Characteristics of Continuous-Streamflow Record Gaging Stations}

The annual series data calculated at continuous-streamflow record gaging stations were assumed to fit a parametric distribution so that return period flows could be estimated. 
The log Pearson Type III distribution was used to fit the annual series values. However, other distributions, such as the log normal and Weibull distributions, have been shown in other studies (Tasker, 1987) to fit annual low flows equally as well. From the fitted distribution and associated probability plot, return period flows can be computed based on the desired nonexceedence probability. For example, a stream's $\mathrm{Q}_{7}$ that has a non-exceedence probability of 0.1 has a 10 percent chance of the discharge being equal to or less than the $\mathrm{Q}_{7}$ value each year. The $d$-day, $T$-year low flows were computed by solving the equation:

$$
\log _{10}\left(Q_{d-\text { day }, T-\text { year }}\right)=\hat{X}+K \hat{S}
$$

where

$$
\begin{aligned}
& Q \text { is the } d \text {-day, } T \text {-year low flow, } \\
& \hat{X} \text { is the estimate of the mean of the logarithms } \\
& \text { of the low-flow series, } \\
& K \text { is a frequency factor for Pearson Type III } \\
& \text { distributions (Interagency Advisory } \\
& \text { Committee on Water Data, 1982), and } \\
& \hat{S} \text { is the estimate of the standard deviation of the } \\
& \text { logs of the annual low-flow series. }
\end{aligned}
$$

Equation 1 is based on log (base 10) logarithms, so a conditional probability adjustment (SWSTAT version 4.1; conditional probability adjustment based on methods by Tasker (1987)) was used on time series that contained values equal to zero or outlier values.

Continuous-streamflow record gaging stations involved in the frequency analysis were required to have 10 years or more of continuous-streamflow record. Continuous-streamflow record gaging stations having less than 10 years of continuousstreamflow record were analyzed by the same procedures as those used for partial-record stations and were labeled as such.

\section{Calculation of Low-Flow Characteristics at Partial-Record Gaging Stations}

Partial-record stations and those continuous-streamflow record stations with less than 10 years of streamflow record (also listed as partial-record stations in this report) have insufficient data for fitting the log Pearson Type III distribution. However, daily-mean discharge from short-term continuousstreamflow record gaging stations and discharge measurements made during base-flow periods at partial-record stations may be estimated from daily-mean discharge at nearby longterm continuous-streamflow record stations (index stations).

Low-flow frequencies at partial-record gaging stations were estimated by the use of two different methods (table 2). Streamflow data for most of the 101 partial-record gaging stations were analyzed by the base-flow correlation method
(Stedinger and Thomas, 1985); however, if the base-flow correlation method could not be used, the graphical method (Riggs, 1972) was used.

\section{Calculation of Low-Flow Characteristics at Partial-Record Gaging Stations Using the Base- Flow Correlation Method}

For most of the partial-record gaging stations analyzed in this study, the base-flow correlation method was used. A detailed explanation is included in appendix 1. In summary, the base-flow correlation method computes an annual time series, mean, and a standard deviation of averaged consecutive 7-day minimum discharge from the index site to the partialrecord site, and computes a return period flow using equation 1-1. The index stations were selected based on geographic proximity and by maximization of the correlation coefficient between concurrent flows.

\section{Calculation of Low-Flow Characteristics at Partial-Record Stations Using the Graphical Method}

There were several stations for which the graphical method was used to determine the low-flow characteristics. The graphical method was used when there were fewer than 10 discharge measurements at the partial-record stations or when relations between the log of the discharge measurements at the partial-record station and index site were not linear.

The graphical method involves plotting (on log-log paper) the measured discharges at partial-record stations and the concurrent daily-mean discharge at the nearby index site to define the relation between the two sets of data. Lowflow characteristics at the partial-record station can then be estimated by transferring the low-flow characteristics from the index station using the visually determined relation to the partial-record station (fig. 2).

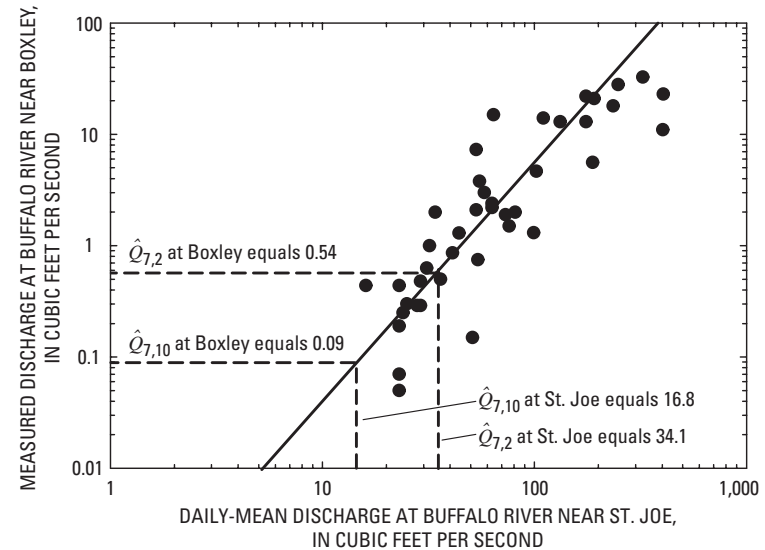

Figure 2. Relation between daily-mean discharge at continuous streamflow-record gaging station Buffalo River near St. Joe, Arkansas, and measured discharge at partial-record station, Buffalo River near Boxley, Arkansas. 
Table 2. Partial-record gaging stations analyzed for low-flow characteristics and the method and index station used for this [lat, latitude; long, longitude; mi, mile; $\mathrm{mi}^{2}$, square mile; $\mathrm{ft}^{3} / \mathrm{s}$, cubic foot per second; Horizontal datum is NAD of 1927 or NAD of 1983 ; S, Stedinger and

\begin{tabular}{|c|c|c|}
\hline $\begin{array}{l}\text { Station } \\
\text { number }\end{array}$ & Station name & Station location \\
\hline 07047976 & White River at Combs & $\begin{array}{l}\text { Lat } 35^{\circ} 49 \text { " } 40 \text { "long } 93^{\circ} 49^{\prime} 54^{\prime \prime}, \text { NW } 1 / 4 \text { sec. } 2 \text {, } \\
\text { T.13 N., R. } 27 \text { W., at bridge on state Highway } 295,0.3 \text { mile } \\
\text { northeast of Combs. }\end{array}$ \\
\hline 07047980 & White River at Elkins & $\begin{array}{l}\text { Lat } 36^{\circ} 00^{\prime} 03^{\prime \prime}, \text { long } 94^{\circ} 00^{\prime} 13^{\prime \prime}, \text { SE } 1 / 4 \text { sec. } 1 \text {, } \\
\text { T.15 N., R.29 W., at highway bridge at Elkins. }\end{array}$ \\
\hline 07048550 & West Fork White River east of Fayetteville & $\begin{array}{l}\text { Lat } 36^{\circ} 03^{\prime} 14^{\prime \prime} \text {, long } 94^{\circ} 04^{\prime} 59^{\prime \prime} \text { in NE } 1 / 4 \text { NW } 1 / 4 \text { sec. } 20 \text {, } \\
\text { T.16 N., R.29 W., Washington County, Ark. Hydrologic } \\
\text { Unit } 11010001 \text {, attached to the upstream wingwall on left } \\
\text { bank, on Mally Wagnon Road, } 6 \text { miles east of Fayetteville, } \\
\text { about } 1.4 \text { miles above the confluence with the White River. }\end{array}$ \\
\hline 07048960 & War Eagle Creek near Huntsville & $\begin{array}{l}\text { Lat } 36^{\circ} 02^{\prime} 30^{\prime \prime} \text {, long } 93^{\circ} 42^{\prime} 17^{\prime \prime}, \text { SE } 1 / 4 \mathrm{NW} 1 / 4 \mathrm{sec} .23 \text {, } \\
\text { T.16 N., R. } 26 \text { W., at bridge on State Highway } 23 \text { and } 3.6 \\
\text { miles south of Huntsville. }\end{array}$ \\
\hline 07050225 & Kings River near Kingston & $\begin{array}{l}\text { Lat } 36^{\circ} 05^{\prime} 17^{\prime \prime}, \text { long } 93^{\circ} 32^{\prime} 30^{\prime \prime}, \text { SE } 1 / 4 \mathrm{sec} .33 \text {, T. } 17 \text { N., } \\
\text { R. } 24 \text { W., at bridge on State Highway } 21 \text { and } 3.5 \text { miles } \\
\text { northwest of Kingston. }\end{array}$ \\
\hline 07053200 & Long Creek at Alpena & $\begin{array}{l}\text { Lat } 36^{\circ} 17^{\prime} 31^{\prime \prime} \text {, long } 93^{\circ} 16^{\prime} 54^{\prime \prime}, \mathrm{NW} 1 / 4 \mathrm{sec} .24 \text {, T. } 19 \text { N., } \\
\text { R. } 22 \text { N., at bridge on U.S. Highway } 62,0.7 \text { mile east of } \\
\text { Alpena. }\end{array}$ \\
\hline 07053207 & Long Creek at Denver & $\begin{array}{l}\text { Lat } 36^{\circ} 23^{\prime} 23^{\prime} \text {, long } 93^{\circ} 19^{\prime} 01^{\prime \prime} \mathrm{NW} 1 / 4 \text { NE } 1 / 4 \text { SE } 1 / 4 \\
\text { sec. } 16 \text {, T.20 N., R. } 22 \text { W., Carroll County, Ark. Hydrologic } \\
\text { Unit } 11010001 \text {, on left bank, at the downstream side of } \\
\text { county road, } 0.2 \text { miles southwest of Denver and } 0.4 \text { mile } \\
\text { upstream from Dry Creek. }\end{array}$ \\
\hline
\end{tabular}


analysis.

Thomas base-flow correlation methods (1985); G, graphical (Riggs, 1972)]

\begin{tabular}{|c|c|c|c|c|c|c|}
\hline Period of measurements & $\begin{array}{c}\text { Identifier } \\
\text { number } \\
\text { (figure 1, } \\
\text { plate 1, } \\
\text { table 1) }\end{array}$ & $\begin{array}{c}\text { Number of } \\
\text { measurements }\end{array}$ & $\begin{array}{c}\text { Drainage } \\
\text { area } \\
\left(\mathrm{mi}^{2}\right)\end{array}$ & Method & $\begin{array}{c}\text { Index } \\
\text { station } \\
\text { number }\end{array}$ & $\begin{array}{l}\text { Index station } \\
\text { identifier } \\
\text { number } \\
\text { (figure 1, } \\
\text { plate 1, table 1) }\end{array}$ \\
\hline $\begin{array}{l}\text { 7/1964 - 9/1967, } \\
8 / 1988 \text { - 10/1988 }\end{array}$ & 76 & 12 & 89.6 & $S$ & 07048600 & 1 \\
\hline $\begin{array}{l}8 / 1957 \text { - 7/1963, } \\
9 / 1987-10 / 1988\end{array}$ & 77 & 20 & 182 & $S$ & 07048000 & 48 \\
\hline $\begin{array}{l}7 / 1964 \text { - 9/1967, } \\
9 / 1987 \text { - 10/1988, } \\
11 / 1999-9 / 2004\end{array}$ & 78 & 23 & 72.2 & $S$ & 07048600 & 1 \\
\hline $\begin{array}{l}9 / 1985 \text { - 6/1996, } \\
3 / 1999-8 / 2005\end{array}$ & 32 & 44 & 122 & $S$ & 07048600 & 1 \\
\hline $\begin{array}{l}8 / 1954-8 / 1963 \\
10 / 1998-8 / 2005\end{array}$ & 33 & 41 & 140 & $S$ & 07049000 & 2 \\
\hline 7/1964 - 9/1967 & 79 & 9 & 105 & G & 07049000 & 2 \\
\hline $11 / 1963-9 / 1967$ & 80 & 10 & 100 & S & 07050500 & 3 \\
\hline $11 / 1963-9 / 1967$ & 81 & 9 & 348 & G & 07050500 & 3 \\
\hline 4/1997 - 6/2005 & 82 & 11 & 150 & $S$ & 07050500 & 3 \\
\hline $8 / 1957-11 / 1963$ & 83 & 14 & 67.4 & G & 07050500 & 3 \\
\hline $8 / 1993-9 / 2005$ & 34 & 27 & 103 & $S$ & 07053250 & 4 \\
\hline
\end{tabular}


Table 2. Partial-record gaging stations analyzed for low-flow characteristics and the method and index station used for this [lat, latitude; long, longitude; mi, mile; $\mathrm{mi}^{2}$, square mile; $\mathrm{ft}^{3} / \mathrm{s}$, cubic foot per second; Horizontal datum is NAD of 1927 or NAD of 1983; S, Stedinger and

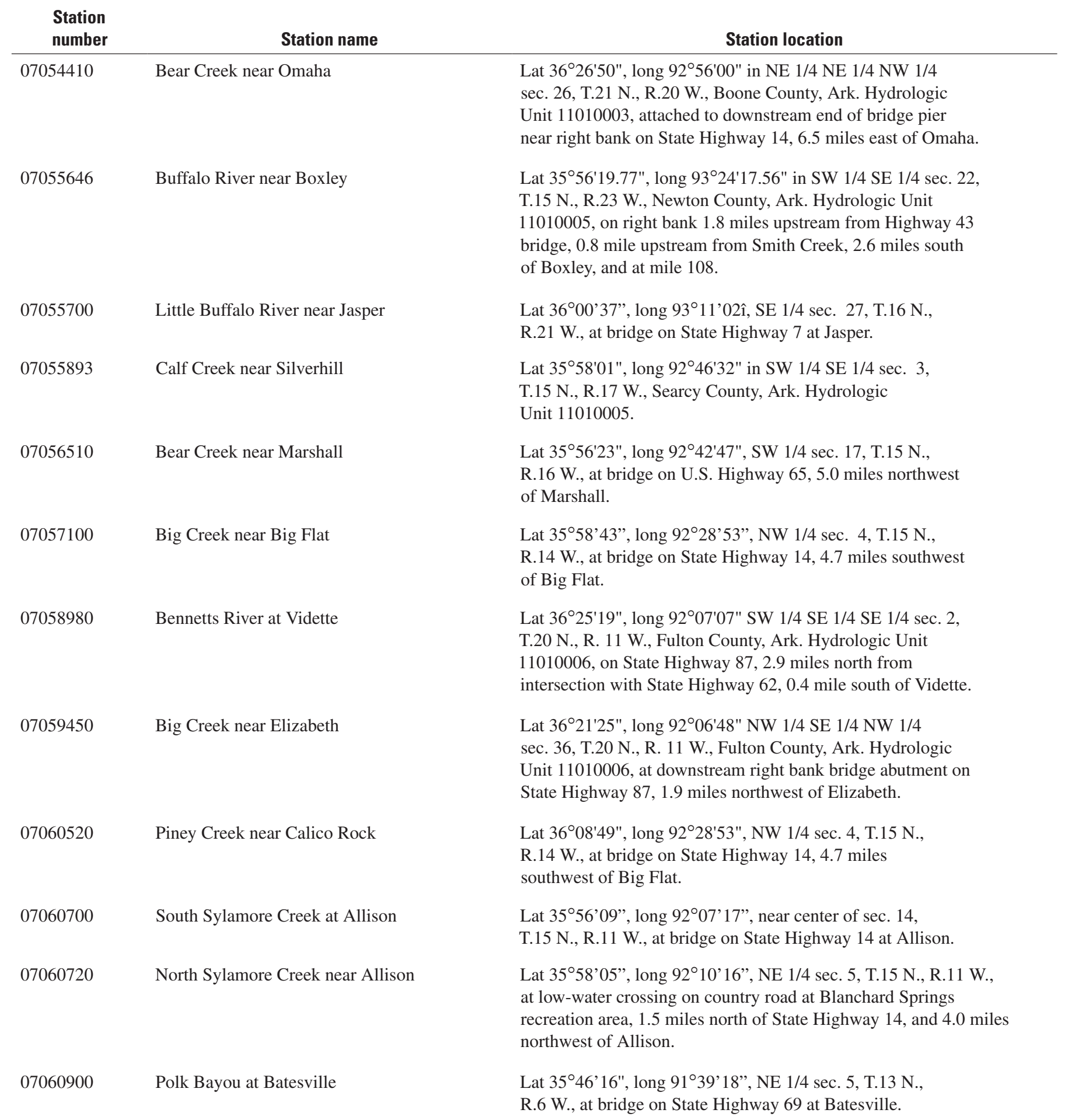


analysis.-Continued

Thomas base-flow correlation methods (1985); G, graphical (Riggs, 1972)]

\begin{tabular}{|c|c|c|c|c|c|c|}
\hline Period of measurements & $\begin{array}{c}\text { Identifier } \\
\text { number } \\
\text { (figure 1, } \\
\text { plate 1, } \\
\text { table 1) }\end{array}$ & $\begin{array}{c}\text { Number of } \\
\text { measurements }\end{array}$ & $\begin{array}{c}\text { Drainage } \\
\text { area } \\
\left(\mathrm{mi}^{2}\right)\end{array}$ & Method & $\begin{array}{l}\text { Index } \\
\text { station } \\
\text { number }\end{array}$ & $\begin{array}{l}\text { Index station } \\
\text { identifier } \\
\text { number } \\
\text { (figure 1, } \\
\text { plate 1, table 1) }\end{array}$ \\
\hline 7/1997 - 9/2005 & 35 & 30 & 133 & $\mathrm{~S}$ & 07053250 & 4 \\
\hline $7 / 1993-9 / 2005$ & 36 & 41 & 59.2 & $\mathrm{G}$ & 07056000 & 6 \\
\hline $\begin{array}{l}\text { 10/1953 -9/1967, 7/1974 - 8/1978, } \\
8 / 1987 \text { - 7/1991 }\end{array}$ & 84 & 25 & 126 & S & 07056000 & 6 \\
\hline $7 / 1993-9 / 2005$ & 37 & 18 & 45.1 & S & 07056000 & 6 \\
\hline $\begin{array}{l}9 / 1958-11 / 1963, \\
6 / 1969, \\
9 / 1987-11 / 1990\end{array}$ & 85 & 14 & 80.8 & S & 07056000 & 6 \\
\hline $\begin{array}{l}\text { 6/1969, } \\
4 / 2001-10 / 2003\end{array}$ & 86 & 33 & 91.0 & S & 07056000 & 6 \\
\hline $\begin{array}{l}7 / 1964-6 / 1969 \\
8 / 1987-10 / 1988\end{array}$ & 38 & 29 & 68.3 & S & 07053250 & 4 \\
\hline $\begin{array}{l}8 / 1957-9 / 1967 \\
8 / 1987-10 / 1988\end{array}$ & 39 & 33 & 52.1 & S & 07056000 & 6 \\
\hline $7 / 1994-8 / 2005$ & 87 & 12 & 78.4 & S & 07074000 & 54 \\
\hline 9/1994 - 5/2005 & 88 & 19 & 142 & S & 07074000 & 54 \\
\hline $\begin{array}{l}\text { 7/1964 - 9/1967, } \\
9 / 1987-10 / 1988\end{array}$ & 89 & 8 & 68.5 & $\mathrm{G}$ & 07060710 & 7 \\
\hline $\begin{array}{l}8 / 1958-8 / 1963 \\
9 / 1987-10 / 1988\end{array}$ & 90 & 20 & 168 & $\mathrm{~S}$ & 07074000 & 54 \\
\hline
\end{tabular}


Table 2. Partial-record gaging stations analyzed for low-flow characteristics and the method and index station used for this [lat, latitude; long, longitude; mi, mile; $\mathrm{mi}^{2}$, square mile; $\mathrm{ft}^{3} / \mathrm{s}$, cubic foot per second; Horizontal datum is NAD of 1927 or NAD of 1983; S, Stedinger and

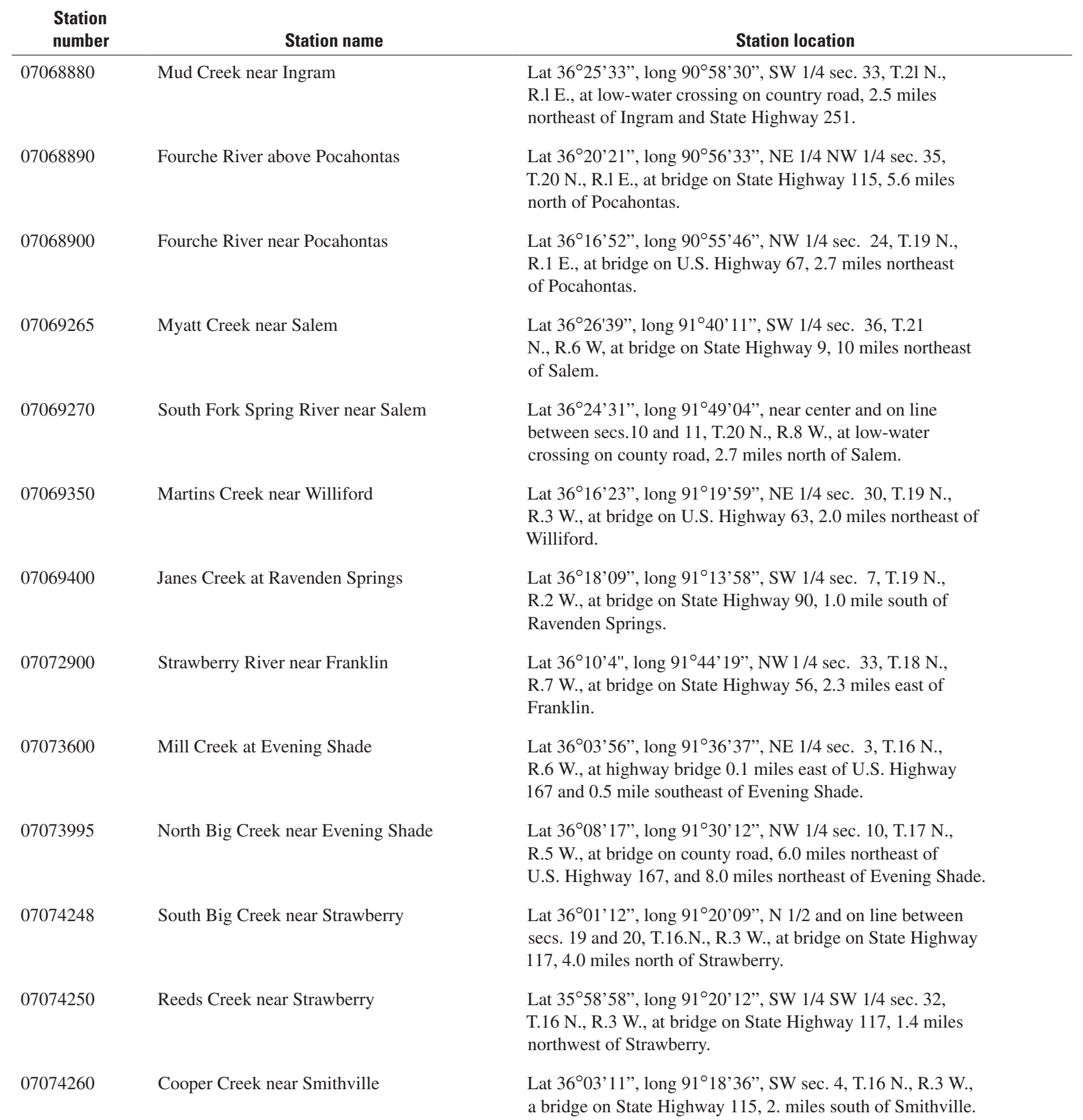


analysis.-Continued

Thomas base-flow correlation methods (1985); G, graphical (Riggs, 1972)]

\begin{tabular}{|c|c|c|c|c|c|c|}
\hline Period of measurements & $\begin{array}{c}\text { Identifier } \\
\text { number } \\
\text { (figure 1, } \\
\text { plate 1, } \\
\text { table 1) }\end{array}$ & $\begin{array}{c}\text { Number of } \\
\text { measurements }\end{array}$ & $\begin{array}{c}\text { Drainage } \\
\text { area } \\
\left(\mathrm{mi}^{2}\right)\end{array}$ & Method & $\begin{array}{c}\text { Index } \\
\text { station } \\
\text { number }\end{array}$ & $\begin{array}{l}\text { Index station } \\
\text { identifier } \\
\text { number } \\
\text { (figure 1, } \\
\text { plate 1, table 1) }\end{array}$ \\
\hline $\begin{array}{l}\text { 12/1965 - 9/1967, } \\
9 / 1987 \text { - 10/1988 }\end{array}$ & 91 & 10 & 34.3 & $S$ & 07074000 & 54 \\
\hline $\begin{array}{l}\text { 9/1957 - 9/1964, } \\
8 / 1987 \text { - 10/1988 }\end{array}$ & 40 & 46 & 229 & S & 07074000 & 54 \\
\hline $\begin{array}{l}\text { 7/1964 - 9/1967, } \\
9 / 1987 \text { - 10/1988 }\end{array}$ & 92 & 14 & 299 & $S$ & 07074000 & 54 \\
\hline $\begin{array}{l}\text { 10/1964 - 9/1970, } \\
6 / 1978 \text { - 8/1978, } \\
8 / 1987 \text { - 8/1988 }\end{array}$ & 93 & 9 & 102 & G & 07074000 & 54 \\
\hline $\begin{array}{l}8 / 1958-9 / 1963 \\
1 / 1967 \\
10 / 1987\end{array}$ & 94 & 7 & 170 & G & 07074000 & 54 \\
\hline $\begin{array}{l}\text { 7/1964 - 11/1966, } \\
9 / 1987 \text { - 10/1988 }\end{array}$ & 95 & 11 & 67.0 & $\mathrm{~S}$ & 07074000 & 54 \\
\hline $\begin{array}{l}\text { 10/1964 - 11/1966, } \\
\text { 9/1987 }\end{array}$ & 96 & 22 & 79.2 & G & 07074000 & 54 \\
\hline $\begin{array}{l}\text { 9/1953, } \\
7 / 1964 \text { - 9/1967, } \\
9 / 1987 \text { - 10/1988 }\end{array}$ & 97 & 9 & 153 & G & 07074000 & 54 \\
\hline $\begin{array}{l}8 / 1958 \text { - 10/1965, } \\
9 / 1987 \text { - 10/1988 }\end{array}$ & 98 & 20 & 12.1 & $S$ & 07074000 & 54 \\
\hline $\begin{array}{l}\text { 7/1964 - 9/1967, } \\
9 / 1987\end{array}$ & 99 & 11 & 74.8 & $\mathrm{~S}$ & 07074000 & 54 \\
\hline $\begin{array}{l}\text { 9/1956 - 8/1963, } \\
9 / 1987-10 / 1988\end{array}$ & 100 & 17 & 69.4 & S & 07056000 & 6 \\
\hline $\begin{array}{l}\text { 7/1964 - 11/1966, } \\
\text { 9/1987 - 10/1988, } \\
9 / 2002\end{array}$ & 101 & 17 & 35.0 & $\mathrm{~S}$ & 07074000 & 54 \\
\hline $\begin{array}{l}\text { 7/1964 - 9/1967, } \\
\text { 9/1987 - 10/1988, 8/2001 - 9/2002 }\end{array}$ & 102 & 10 & 32.2 & S & 07074000 & 54 \\
\hline
\end{tabular}


Table 2. Partial-record gaging stations analyzed for low-flow characteristics and the method and index station used for this [lat, latitude; long, longitude; mi, mile; $\mathrm{mi}^{2}$, square mile; $\mathrm{ft}^{3} / \mathrm{s}$, cubic foot per second; Horizontal datum is NAD of 1927 or NAD of 1983; S, Stedinger and

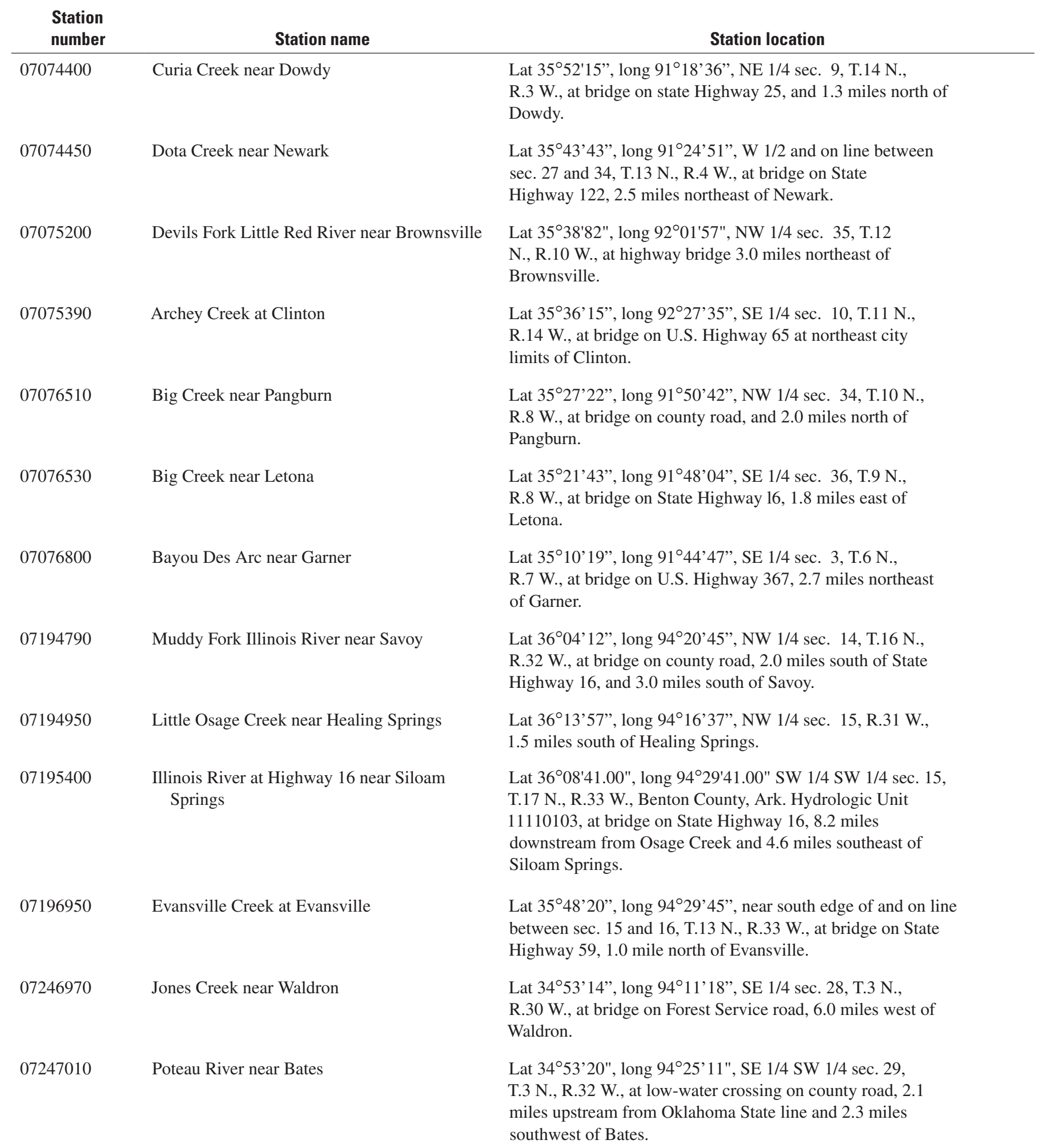


analysis.-Continued

Thomas base-flow correlation methods (1985); G, graphical (Riggs, 1972)]

\begin{tabular}{|c|c|c|c|c|c|c|}
\hline Period of measurements & $\begin{array}{c}\text { Identifier } \\
\text { number } \\
\text { (figure 1, } \\
\text { plate 1, } \\
\text { table 1) }\end{array}$ & $\begin{array}{c}\text { Number of } \\
\text { measurements }\end{array}$ & $\begin{array}{c}\text { Drainage } \\
\text { area } \\
\left(\mathrm{mi}^{2}\right)\end{array}$ & Method & $\begin{array}{l}\text { Index } \\
\text { station } \\
\text { number }\end{array}$ & $\begin{array}{l}\text { Index station } \\
\text { identifier } \\
\text { number } \\
\text { (figure 1, } \\
\text { plate 1, table 1) }\end{array}$ \\
\hline $\begin{array}{l}\text { 10/1964 - 11/1966, } \\
\text { 9/1987 - 10/1988, } \\
1 / 2002 \text { - 9/2002 }\end{array}$ & 103 & 12 & 55.6 & S & 07074000 & 54 \\
\hline $\begin{array}{l}\text { 7/1964 - 11/1966, } \\
9 / 1987 \text { - 10/1989 }\end{array}$ & 104 & 13 & 56.6 & S & 07074000 & 54 \\
\hline $\begin{array}{l}\text { 10/1963 - 11/1966, } \\
\text { 9/1987 }\end{array}$ & 105 & 16 & 195 & $S$ & 07261000 & 22 \\
\hline $\begin{array}{l}\text { 10/1963 - 11/1966, } \\
9 / 1987 \text { - 10/1989 }\end{array}$ & 106 & 10 & 119 & $S$ & 07075300 & 8 \\
\hline $\begin{array}{l}\text { 9/1957 - 10/1961, } \\
7 / 1968, \\
9 / 1987 \text { - 10/1988 }\end{array}$ & 107 & 11 & 84.3 & $\mathrm{~S}$ & 07261000 & 22 \\
\hline $\begin{array}{l}\text { 7/1964 - 9/1967, } \\
9 / 1987 \text { - 10/1988 }\end{array}$ & 108 & 11 & 72.5 & S & 07261000 & 22 \\
\hline $\begin{array}{l}\text { 7/1964 - 9/1967, } \\
8 / 1988 \text { - 10/1988 }\end{array}$ & 109 & 16 & 96.9 & S & 07261000 & 22 \\
\hline $\begin{array}{l}\text { 7/1964 - 9/1967, } \\
10 / 1988\end{array}$ & 110 & 9 & 73.5 & G & 07049000 & 2 \\
\hline $\begin{array}{l}\text { 9/1957 - 8/1963, } \\
\text { 9/1987 }\end{array}$ & 111 & 21 & 46.1 & S & 07049000 & 2 \\
\hline $11 / 1963-9 / 1967$ & 41 & 21 & 510 & $\mathrm{~S}$ & 07194800 & 9 \\
\hline $8 / 1954-7 / 1963$ & 112 & 22 & 23.6 & $\mathrm{~S}$ & 07196900 & 12 \\
\hline $\begin{array}{l}7 / 1979 \text { - 12/1981, } \\
8 / 1985 \text { - 9/1986, } \\
3 / 1996 \text { - 2/2006 }\end{array}$ & 113 & 9 & 70.4 & G & 07196900 & 12 \\
\hline $\begin{array}{l}6 / 1958-10 / 1963 \\
9 / 1987-10 / 1988\end{array}$ & 114 & 10 & 251 & $\mathrm{~S}$ & 07196900 & 12 \\
\hline
\end{tabular}


Table 2. Partial-record gaging stations analyzed for low-flow characteristics and the method and index station used for this [lat, latitude; long, longitude; mi, mile; $\mathrm{mi}^{2}$, square mile; $\mathrm{ft}^{3} / \mathrm{s}$, cubic foot per second; Horizontal datum is NAD of 1927 or NAD of 1983; S, Stedinger and

\begin{tabular}{ll}
$\begin{array}{r}\text { Station } \\
\text { number }\end{array}$ & Station name \\
\hline 07247100 & Black Fork near Page, Okla. \\
07247200 & Big Creek at Howard \\
07247300 & Haws Creek near Black Fork \\
07249600 & Lee Creek at Natural Dam \\
07249700 & Mountain Fork Creek at Natural Dam \\
07249800 & Lee Creek at Short, Okla.
\end{tabular}

$07250600 \quad$ Vache Grasse Creek near Lavaca

$07250935 \quad$ Jones Creek at Winfrey

$07250965 \quad$ Frog Bayou near Winfrey

$07250974 \quad$ Jack Creek near Winfrey

$07251400 \quad$ Cedar Creek near Rudy

\section{Station location}

Lat $34^{\circ} 45^{\prime} 35^{\prime \prime}$, long 94²9’34", sec. 5, T.3 N., R.27 E., at highway bridge, 2.0 miles west of Arkansas-Oklahoma State line and 5.0 miles northeast of Page.

Lat $34^{\circ} 42^{\prime} 24^{\prime \prime}$, long $94^{\circ} 26^{\prime} 14^{\prime \prime}$, sec. 31 , T.1 N., R.32 W., 300 feet north of U.S. Highway 270, 1.0 mile east of Arkansas-Oklahoma State line at Howard.

Lat $34^{\circ} 47^{\prime} 36^{\prime \prime}$, long $94^{\circ} 24^{\prime} 58^{\prime \prime}$, sec. 32 , T.2 N., R.32 W., at highway bridge, 2.0 miles east of Arkansas-Oklahoma State line and 2.0 miles north of Black Fork.

Lat $35^{\circ} 38^{\prime} 46^{\prime \prime}$, long 94²3'37", SW 1/4 sec. 10, T.11 N., R.32 W., at bridge on State Highway 59 at natural Dam.

Lat $35^{\circ} 38^{\prime} 43^{\prime \prime}$, long 94²3'49", SE 1/4 sec. 9, T.11 N., R.32 W., at bridge on State Highway 59 at Natural Dam.

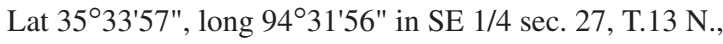
R.26 E., Sequoyah County, Okla., Hydrologic Unit 11110104, on right bank at right downstream end of bridge on State Highway 101, 0.5 mile west of Short, Okla.

Lat $35^{\circ} 19^{\prime} 03^{\prime \prime}$, long $94^{\circ} 12^{\prime} 55^{\prime \prime}$, NW 1/4 sec. 5, T.7 N., R.30 W., at bridge on State Highway 22, 2.5 miles south of Lavaca.

Lat $35^{\circ} 44^{\prime} 12^{\prime \prime}$, long $94^{\circ} 06^{\prime} 11^{\prime \prime}$ in SE $1 / 4$ SW $1 / 4$ sec. 5, T.12 N., R.29 W., Crawford County, Ark. Hydrologic Unit 11110201, near left bank in pasture 300 feet upstream of bridge on Winfrey Valley Cutoff, 3 miles northeast of junction of U.S. Highway 71 and Winfrey Valley Cutoff, and 10.6 miles northeast of Mountainburg, Ark.

Lat $35^{\circ} 43^{\prime} 37^{\prime \prime}$, long $94^{\circ} 06^{\prime} 26^{\prime \prime}$ in SE 1/4 SE 1/4 sec. 7, T.12 N., R.29 W., Crawford County, Ark. Hydrologic Unit 11110201, near right bank in pasture, 4.0 miles southeast of junction of U.S. Highway 71 and Winfrey Valley Cutoff, and 11.6 miles northeast of Mountainburg, Ark.

Lat $35^{\circ} 42^{\prime} 19^{\prime \prime}$, long $94^{\circ} 05^{\prime} 21^{\prime \prime}$ in NE $1 / 4$ NE $1 / 4$ sec. 20 , T.12 N., R.29 W., Crawford County, Ark. Hydrologic Unit 11110201, 2100 feet upstream of mouth at Lake Shepherd SpringS., 8.7 miles northeast of the junction of U.S. Highway 71 and State Highway 282, and 11.3 miles northeast of Mountainburg, Ark.

Lat 35'31'45", long 94×16’39", 1/4 sec. 22, T.10 N., R.31 W., 200 feet upstream from mouth and 0.5 mile northwest of Rudy. 
analysis.-Continued

Thomas base-flow correlation methods (1985); G, graphical (Riggs, 1972)]

\begin{tabular}{|c|c|c|c|c|c|c|}
\hline Period of measurements & $\begin{array}{c}\text { Identifier } \\
\text { number } \\
\text { (figure 1, } \\
\text { plate 1, } \\
\text { table 1) }\end{array}$ & $\begin{array}{c}\text { Number of } \\
\text { measurements }\end{array}$ & $\begin{array}{l}\text { Drainage } \\
\text { area } \\
\left(\mathrm{mi}^{2}\right)\end{array}$ & Method & $\begin{array}{l}\text { Index } \\
\text { station } \\
\text { number }\end{array}$ & $\begin{array}{l}\text { Index station } \\
\text { identifier } \\
\text { number } \\
\text { (figure 1, } \\
\text { plate 1, table 1) }\end{array}$ \\
\hline $\begin{array}{l}11 / 1964-10 / 1963 \\
9 / 1987-10 / 1988\end{array}$ & 115 & 13 & 47.0 & $\mathrm{~S}$ & 07249400 & 14 \\
\hline $\begin{array}{l}\text { 11/1964 - 10/1963 } \\
9 / 1987-10 / 1988\end{array}$ & 116 & 17 & 11.1 & $\mathrm{~S}$ & 07249400 & 14 \\
\hline $\begin{array}{l}8 / 1958-4 / 1963 \\
8 / 1988-10 / 1989\end{array}$ & 117 & 17 & 8.0 & $\mathrm{~S}$ & 07249400 & 14 \\
\hline $\begin{array}{l}8 / 1958 \text { - 4/1963, } \\
8 / 1987 \text { - 10/1989 }\end{array}$ & 118 & 35 & 169 & $\mathrm{~S}$ & 07249985 & 15 \\
\hline $\begin{array}{l}8 / 1958-4 / 1963 \\
8 / 1988-9 / 1988\end{array}$ & 119 & 32 & 14.9 & $S$ & 07196900 & 12 \\
\hline $\begin{array}{l}\text { 9/1957 - 10/1963, } \\
8 / 1968, \\
3 / 1971 \text { - 11/1973, } \\
8 / 1988 \text { - 10/1988 }\end{array}$ & 42 & 43 & 242 & $S$ & 07249985 & 15 \\
\hline $\begin{array}{l}6 / 1958-7 / 1963, \\
3 / 1971-3 / 1974, \\
8 / 1987-10 / 1988\end{array}$ & 120 & 25 & 105 & $\mathrm{~S}$ & 07249985 & 15 \\
\hline $\begin{array}{l}8 / 1958-7 / 1963 \\
8 / 1987-10 / 1988 \\
9 / 1999-6 / 2005\end{array}$ & 43 & 18 & 20.3 & $S$ & 07252000 & 16 \\
\hline $\begin{array}{l}8 / 1958-8 / 1963 \\
8 / 1987-9 / 1988 \\
2 / 2003-1 / 2004\end{array}$ & 44 & 16 & 54.9 & $S$ & 07249985 & 15 \\
\hline $4 / 2001-6 / 2005$ & 45 & 14 & 6.9 & $\mathrm{~S}$ & 07249985 & 15 \\
\hline $4 / 2001-6 / 2005$ & 121 & 21 & 51.4 & S & 07249985 & 15 \\
\hline
\end{tabular}


Table 2. Partial-record gaging stations analyzed for low-flow characteristics and the method and index station used for this [lat, latitude; long, longitude; mi, mile; $\mathrm{mi}^{2}$, square mile; $\mathrm{ft}^{3} / \mathrm{s}$, cubic foot per second; Horizontal datum is NAD of 1927 or NAD of 1983; S, Stedinger and

\begin{tabular}{|c|c|c|}
\hline $\begin{array}{l}\text { Station } \\
\text { number }\end{array}$ & Station name & Station location \\
\hline 07251800 & Little Mulberry Creek near Oark & $\begin{array}{l}\text { Lat } 35^{\circ} 41^{\prime} 111^{\prime \prime}, \text { long } 93^{\circ} 39^{\prime} 45^{\prime \prime}, \mathrm{SW} 1 / 4 \mathrm{sec} .21, \mathrm{~T} .12 \mathrm{~N} . \text {, } \\
\text { R. } 25 \mathrm{~W} \text {., at bridge on Forest Service road, } 3.7 \text { miles west of } \\
\text { end of State Highway } 103 \text { and } 5.0 \text { miles west of Oark. }\end{array}$ \\
\hline 07251900 & Mulberry River near Cass & $\begin{array}{l}\text { Lat } 35^{\circ} 40^{\prime} 10^{\prime \prime} \text {, long } 93^{\circ} 49^{\prime} 46^{\prime \prime}, \mathrm{NE} 1 / 4 \mathrm{sec} .35 \text {, T. } 12 \mathrm{~N} . \text {, } \\
\text { R. } 27 \text { W., at bridge on State Highway } 23,1.5 \text { miles southwest } \\
\text { of Cass. }\end{array}$ \\
\hline 07252100 & Little Mulberry Creek near Mulberry & $\begin{array}{l}\text { Lat } 35^{\circ} 30^{\prime} 37^{\prime \prime} \text {, long } 94^{\circ} 04^{\prime} 15^{\prime \prime}, \text { SW } 1 / 4 \mathrm{sec} .27 \text {, T. } 10 \text { N., } \\
\text { R. } 29 \text { W., at bridge on U.S. Highway } 64,1.2 \text { miles northwest } \\
\text { of Mulberry. }\end{array}$ \\
\hline 07252300 & White Oak Creek near Ozark & $\begin{array}{l}\text { Lat } 35^{\circ} 30^{\prime} 24^{\prime \prime} \text {, long } 93^{\circ} 56^{\prime} 45^{\prime \prime}, \text { SW } 1 / 4 \text { sec. } 26, \text { T. } 10 \text { N., } \\
\text { R. } 28 \text { W., at bridge on U.S. Highway } 64,7.0 \text { miles west of Ozark. }\end{array}$ \\
\hline 07256700 & Big Shoal Creek near New Blaine & $\begin{array}{l}\text { Lat } 35^{\circ} 17^{\prime} 30^{\prime \prime} \text {, long } 93^{\circ} 27^{\prime} 35^{\prime \prime}, \text { SE } 1 / 4 \text { sec. } 5 \text {, T.7 N., } \\
\text { R. } 23 \text { W., at bridge on State Highway } 22,2.3 \text { miles west of } \\
\text { New Blaine. }\end{array}$ \\
\hline 07257470 & Middle Fork Illinois Bayou near Hector & $\begin{array}{l}\text { Lat } 35^{\circ} 31^{\prime} 42^{\prime \prime} \text {, long } 92^{\circ} 56^{\prime} 29^{\prime \prime}, \text { E } 1 / 2 \text { sec. } 7, \text { T. } 10 \text { N., } \\
\text { R. } 18 \text { W., at bridge on State Highway } 27,4.9 \text { miles northeast } \\
\text { of Hector. }\end{array}$ \\
\hline 07257480 & North Fork Illinois Bayou near Scottsville & $\begin{array}{l}\text { Lat } 35^{\circ} 30^{\prime} 00^{\prime \prime} \text {, long } 93^{\circ} 01^{\prime} 07^{\prime \prime}, \mathrm{S} 1 / 2 \mathrm{sec} .21 \text {, T.10 N., } \\
\text { R.19 W., at bridge on Forest Service road, } 2.4 \text { miles southwest } \\
\text { of State Highway } 27 \text { and } 4.0 \text { males northeast of Scottsville. }\end{array}$ \\
\hline 07260700 & Point Remove Creek near Morrilton & $\begin{array}{l}\text { Lat } 35^{\circ} 10^{\prime} 56^{\prime \prime}, \text { long } 92 \times 47^{\prime} 01 " \text {, NW } 1 / 4 \text { sec. } 11 \text {, T. } 6 \text { N., } \\
\text { R. } 17 \text { W., at bridge on U.S. Highway } 64,3.0 \text { miles northwest } \\
\text { of Morrilton. }\end{array}$ \\
\hline 07261200 & East Fork Cadron Creek near Enola & $\begin{array}{l}\text { Lat } 35^{\circ} 13^{\prime} 06^{\prime \prime} \text {, long } 92^{\circ} 16^{\prime} 44^{\prime \prime}, \mathrm{NE} 1 / 4 \mathrm{sec} .28 \text {, T. } 7 \text { N., } \\
\text { R.12 W., at bridge on county road, } 2.1 \text { miles south of State } \\
\text { Highway } 225 \text {, and } 4.5 \text { miles west of Enola. }\end{array}$ \\
\hline 07261400 & Mill Creek near Boles & $\begin{array}{l}\text { Lat } 34^{\circ} 44^{\prime} 14 " \text { ", long } 94^{\circ} 04^{\prime} 49^{\prime \prime}, \text { SE } 1 / 4 \text { SE } 1 / 4 \text { sec. } 16 \text {, } \\
\text { T.1 N., R. } 29 \text { W., at bridge on U.S. Highway } 71,4.0 \text { miles } \\
\text { south of Boles. }\end{array}$ \\
\hline
\end{tabular}


analysis.-Continued

Thomas base-flow correlation methods (1985); G, graphical (Riggs, 1972)]

\begin{tabular}{|c|c|c|c|c|c|c|}
\hline Period of measurements & $\begin{array}{c}\text { Identifier } \\
\text { number } \\
\text { (figure 1, } \\
\text { plate 1, } \\
\text { table 1) }\end{array}$ & $\begin{array}{c}\text { Number of } \\
\text { measurements }\end{array}$ & $\begin{array}{c}\text { Drainage } \\
\text { area } \\
\left(\mathrm{mi}^{2}\right)\end{array}$ & Method & $\begin{array}{l}\text { Index } \\
\text { station } \\
\text { number }\end{array}$ & $\begin{array}{l}\text { Index station } \\
\text { identifier } \\
\text { number } \\
\text { (figure 1, } \\
\text { plate 1, table 1) }\end{array}$ \\
\hline $11 / 2001-6 / 2005$ & 122 & 12 & 67.2 & $\mathrm{~S}$ & 07252000 & 16 \\
\hline $\begin{array}{l}8 / 1958 \text { - 8/1963, } \\
8 / 1987 \text { - 10/1988 }\end{array}$ & 123 & 12 & 267 & $\mathrm{~S}$ & 07252000 & 16 \\
\hline $\begin{array}{l}\text { 11/1963 - 9/1967, } \\
8 / 1988-10 / 1988\end{array}$ & 124 & 22 & 51.4 & $\mathrm{~S}$ & 07252000 & 16 \\
\hline $\begin{array}{l}\text { 11/1963 - 9/1967, } \\
9 / 1987-10 / 1988\end{array}$ & 125 & 20 & 75.5 & $\mathrm{~S}$ & 07252000 & 16 \\
\hline $\begin{array}{l}8 / 1957-7 / 1963 \\
10 / 1988\end{array}$ & 126 & 22 & 126 & $\mathrm{~S}$ & 07257006 & 17 \\
\hline $\begin{array}{l}8 / 1957 \text { - 7/1963, } \\
9 / 1987-10 / 1988\end{array}$ & 127 & 25 & 48.8 & $\mathrm{~S}$ & 07257006 & 17 \\
\hline $\begin{array}{l}\text { 9/1952, 8/1957 - 7/1963, } \\
8 / 1973, \\
9 / 1987-10 / 1988\end{array}$ & 128 & 9 & 57.4 & G & 07257500 & 18 \\
\hline $\begin{array}{l}8 / 1957-8 / 1963, \\
9 / 1987-10 / 1988, \\
12 / 2002\end{array}$ & 129 & 9 & 86.7 & G & 07257500 & 18 \\
\hline $11 / 1963-9 / 1967$ & 130 & 17 & 95.0 & $\mathrm{~S}$ & 07260000 & 20 \\
\hline $11 / 1963-9 / 1967$ & 46 & 63 & 221 & $\mathrm{~S}$ & 07257006 & 17 \\
\hline $10 / 1957-9 / 1967$ & 131 & 15 & 489 & $\mathrm{G}$ & 07257006 & 17 \\
\hline $6 / 1978-6 / 2005$ & 132 & 17 & 122 & $\mathrm{~S}$ & 07261000 & 22 \\
\hline $\begin{array}{l}\text { 9/1952, } \\
9 / 1957-8 / 1963\end{array}$ & 133 & 17 & 50.4 & $\mathrm{~S}$ & 07261500 & 23 \\
\hline
\end{tabular}


Table 2. Partial-record gaging stations analyzed for low-flow characteristics and the method and index station used for this [lat, latitude; long, longitude; mi, mile; $\mathrm{mi}^{2}$, square mile; $\mathrm{ft}^{3} / \mathrm{s}$, cubic foot per second; Horizontal datum is NAD of 1927 or NAD of 1983; S, Stedinger and

\begin{tabular}{|c|c|c|}
\hline $\begin{array}{l}\text { Station } \\
\text { number }\end{array}$ & Station name & Station location \\
\hline 07261600 & Gafford Creek near Bluffton & $\begin{array}{l}\text { Lat } 34^{\circ} 53^{\prime} 53^{\prime \prime} \text {, long } 93^{\circ} 36^{\prime} 44^{\prime \prime}, \text { sec. } 24 \text {, T. } 3 \text { N., R. } 25 \text { W., } \\
\text { at bridge on State Highway } 28,0.8 \text { mile southwest of Bluffton. }\end{array}$ \\
\hline 07336900 & Walnut Bayou near Foreman & $\begin{array}{l}\text { Lat } 33^{\circ} 39^{\prime} 14^{\prime \prime} \text {, long } 94^{\circ} 21^{\prime} 33^{\prime \prime} \text {, on east line sec. } 12 \text {, T. } 13 \mathrm{~S} . \text {, } \\
\text { R.32 W., at highway bridge } 5.0 \text { miles southeast of Foreman. }\end{array}$ \\
\hline 07338720 & Mountain Fork near Hatfield & $\begin{array}{l}\text { Lat } 34^{\circ} 30^{\prime} 18^{\prime \prime}, \text { long } 94^{\circ} 25^{\prime} 50^{\prime \prime}, \text { E } 1 / 2 \text { and on line between } \\
\text { sec. } 8 \text { and } 17 \text {, T.3 S., R. } 32 \text { W., at bridge on State Highway } \\
\text { 246, } 3.5 \text { miles northwest of Hatfield. }\end{array}$ \\
\hline 07355810 & Ouachita River near Mena & $\begin{array}{l}\text { Lat } 34^{\circ} 35^{\prime} 01^{\prime \prime} \text {, long } 94^{\circ} 09^{\prime} 06^{\prime \prime}, \mathrm{NW} 1 / 4 \text { NE } 1 / 4 \text { sec. } 13 \text {, } \\
\text { T.2 S., R. } 30 \text { W. at bridge on State Highway } 88,4.7 \text { miles } \\
\text { east of Mena. }\end{array}$ \\
\hline 07357710 & Glazypeau Creek at Mountain Pine & $\begin{array}{l}\text { Lat } 34^{\circ} 34^{\prime} 18^{\prime \prime}, \text { long } 93^{\circ} 09^{\prime} 83^{\prime \prime} \text { SE } 1 / 4 \text { sec. } 8 \text {, T. } 2 \text { S., } \\
\text { R.20 W., at bridge on State Highway } 227,0.5 \text { mile east } \\
\text { of Mountain Pine. }\end{array}$ \\
\hline 07358010 & Fourche A Loupe Creek near Hot Springs & $\begin{array}{l}\text { Lat } 34^{\circ} 23^{\prime} 00^{\prime \prime}, 93^{\circ} 07^{\prime} 57^{\prime \prime}, \mathrm{SW} 1 / 4 \mathrm{sec} .15 \text {, T. } 4 \text { S., R. } 20 \text { W., } \\
\text { at bridge on State Highway } 7 \text { and } 9.2 \text { miles southwest of Hot } \\
\text { Springs. }\end{array}$ \\
\hline 07361025 & Prairie Creek near Murfreesboro & $\begin{array}{l}\text { Lat } 34^{\circ} 02^{\prime} 34^{\prime \prime}, \text { long } 93^{\circ} 41^{\prime} 02^{\prime \prime}, \text { NE } 1 / 4 \text { sec. } 20 \text {, T.8 S., } \\
\text { R. } 25 \text { W., at bridge on State Highway } 301,1.5 \text { miles south of } \\
\text { Murfreesboro. }\end{array}$ \\
\hline 07361160 & North Fork Ozan Creek near McCaskill & $\begin{array}{l}\text { Lat } 33^{\circ} 52^{\prime} 24^{\prime \prime} \text {, long } 93^{\circ} 38^{\prime} 30^{\prime \prime}, \text { near center and on line } \\
\text { between secs. } 14 \text { and } 23 \text {, T. } 10 \text { S., R. } 25 \text { W., at bridge on county } \\
\text { road, } 3.0 \text { miles south of McCaskill. }\end{array}$ \\
\hline 07361540 & Wolf Creek near Antoine & $\begin{array}{l}\text { Lat } 34^{\circ} 01^{\prime} 11^{\prime \prime} \text {, long } 93^{\circ} 26^{\prime} 15^{\prime \prime}, \text { SE } 1 / 4 \text { sec. } 27 \text {, T.8 S., } \\
\text { R. } 23 \text { W., at bridge on State Highway } 29,1.5 \text { miles southwest } \\
\text { of Antoine. }\end{array}$ \\
\hline
\end{tabular}


analysis.-Continued

Thomas base-flow correlation methods (1985); G, graphical (Riggs, 1972)]

\begin{tabular}{|c|c|c|c|c|c|c|}
\hline Period of measurements & $\begin{array}{c}\text { Identifier } \\
\text { number } \\
\text { (figure 1, } \\
\text { plate 1, } \\
\text { table 1) }\end{array}$ & $\begin{array}{c}\text { Number of } \\
\text { measurements }\end{array}$ & $\begin{array}{c}\text { Drainage } \\
\text { area } \\
\left(\mathrm{mi}^{2}\right)\end{array}$ & Method & $\begin{array}{c}\text { Index } \\
\text { station } \\
\text { number }\end{array}$ & $\begin{array}{l}\text { Index station } \\
\text { identifier } \\
\text { number } \\
\text { (figure 1, } \\
\text { plate 1, table 1) }\end{array}$ \\
\hline $\begin{array}{l}6 / 1958-8 / 1963 \\
9 / 1987-10 / 1988\end{array}$ & 134 & 23 & 41.4 & $S$ & 07261500 & 23 \\
\hline $\begin{array}{l}\text { 9/1957 - 8/1963, } \\
7 / 1984,9 / 1988\end{array}$ & 135 & 17 & 90.1 & $\mathrm{~S}$ & 07261500 & 23 \\
\hline $\begin{array}{l}8 / 1957-8 / 1963 \\
7 / 1984,9 / 1987-8 / 1988\end{array}$ & 136 & 27 & 15.9 & $\mathrm{~S}$ & 07356000 & 26 \\
\hline 9/1958 - 8/1963 & 137 & 67 & 168 & $\mathrm{~S}$ & 07356000 & 26 \\
\hline $\begin{array}{l}\text { 11/1963 - 9/1967, } \\
9 / 1987-8 / 1988\end{array}$ & 138 & 9 & 31.1 & G & 07339500 & 65 \\
\hline $\begin{array}{l}5 / 1971-11 / 1973, \\
5 / 1986-8 / 2005\end{array}$ & 139 & 13 & 141 & $\mathrm{~S}$ & 07356000 & 26 \\
\hline 7/1964 - 9/1967 & 140 & 10 & 39.5 & $\mathrm{~S}$ & 07356000 & 26 \\
\hline $\begin{array}{l}\text { 11/1963 - 9/1967, } \\
9 / 1987-9 / 1988\end{array}$ & 141 & 11 & 30.1 & $\mathrm{~S}$ & 07356500 & 70 \\
\hline $\begin{array}{l}\text { 7/1964 - 11/1966, } \\
9 / 1987 \text { - 8/1988 }\end{array}$ & 142 & 13 & 4.7 & $\mathrm{~S}$ & 07356500 & 70 \\
\hline $\begin{array}{l}7 / 1964 \text { - 9/1967, } \\
9 / 1987-10 / 1988\end{array}$ & 143 & 19 & 38.9 & $\mathrm{~S}$ & 07356500 & 70 \\
\hline $\begin{array}{l}7 / 1964-9 / 1967, \\
9 / 1987-10 / 1988\end{array}$ & 47 & 119 & 67.7 & $\mathrm{~S}$ & 07356500 & 70 \\
\hline $\begin{array}{l}\text { 9/1957 - 8/1963, } \\
8 / 1988-10 / 1988\end{array}$ & 144 & 10 & 32.0 & $\mathrm{~S}$ & 07356500 & 70 \\
\hline $6 / 1974-9 / 2205$ & 145 & 5 & 97.3 & G & 07356500 & 70 \\
\hline $\begin{array}{l}\text { 1/1963 - 11/1966, } \\
9 / 1987 \text { - 8/1988 }\end{array}$ & 146 & 10 & 37.5 & $\mathrm{~S}$ & 07356500 & 70 \\
\hline
\end{tabular}


Table 2. Partial-record gaging stations analyzed for low-flow characteristics and the method and index station used for this [lat, latitude; long, longitude; mi, mile; $\mathrm{mi}^{2}$, square mile; $\mathrm{ft}^{3} / \mathrm{s}$, cubic foot per second; Horizontal datum is NAD of 1927 or NAD of 1983; S, Stedinger and

\begin{tabular}{|c|c|c|}
\hline $\begin{array}{l}\text { Station } \\
\text { number }\end{array}$ & Station name & Station location \\
\hline 07361640 & Little Terre Rouge Creek near Emmet & $\begin{array}{l}\text { Lat } 33^{\circ} 44^{\prime} 56^{\prime \prime} \text {, long } 93^{\circ} 27^{\prime} 45^{\prime \prime} \text {, NE } 1 / 4 \text { sec. } 34 \text {, T. } 11 \mathrm{~S} \text {., } \\
\text { R. } 23 \text { W., at bridge on U.S. Highway } 67,1.4 \text { miles northeast } \\
\text { of Emmet. }\end{array}$ \\
\hline 07361650 & Terre Rouge Creek near Prescott & $\begin{array}{l}\text { Lat } 33^{\circ} 46^{\prime} 46^{\prime \prime} \text {, long } 93^{\circ} 14^{\prime} 10^{\prime \prime}, \text { SW } 1 / 4 \text { sec. } 14 \text {, T. } 11 \text { S., } \\
\text { R. } 21 \text { W., at bridge on State Highway } 24,8.5 \text { miles east of } \\
\text { Prescott. }\end{array}$ \\
\hline 07361800 & Terre Noire Creek near Gurdon & $\begin{array}{l}\text { Lat } 33^{\circ} 55^{\prime} 02^{\prime \prime}, \text { long } 93^{\circ} 02^{\prime} 08^{\prime \prime}, \mathrm{SW} 1 / 4 \text { sec. } 27, \mathrm{~T} .2 \mathrm{~S} . \text {, } \\
\text { R.19 W., at highway bridge } 7.0 \text { miles east of Gurdon. }\end{array}$ \\
\hline 07362090 & Camp Creek near Smackover & $\begin{array}{l}\text { Lat } 33^{\circ} 21 \text { ' } 12 " \text {, long } 92^{\circ} 46^{\prime} 28^{\prime \prime}, \text { NE } 1 / 4 \text { sec. } 8 \text { T. } 16 \text { S., } \\
\text { R. } 16 \text { W., at bridge on State Highway 160, } 2.0 \text { miles west } \\
\text { of Smackover city limits. }\end{array}$ \\
\hline 07362600 & Alum Fork Saline River at Crows & $\begin{array}{l}\text { Lat } 34^{\circ} 36^{\prime} 56^{\prime \prime} \text {, long } 92^{\circ} 44^{\prime} 55^{\prime \prime}, \mathrm{NW} 1 / 4 \mathrm{sec} .29 \text {, T. } 1 \mathrm{~S} . \text {, } \\
\text { R.16 W., at bridge on State Highway } 5,1.0 \text { mile east of Crows. }\end{array}$ \\
\hline 07362700 & Middle Fork Saline River at Crows & $\begin{array}{l}\text { Lat } 34^{\circ} 36^{\prime} 54^{\prime \prime} \text {, long } 92^{\circ} 46^{\prime} 44^{\prime \prime}, \text { NW } 1 / 4 \sec 25, \text { T. } \mathrm{S} . \text {, } \\
\text { R.17 W., at bridge on State Highway } 5,0.5 \text { mile west of Crows. }\end{array}$ \\
\hline 07362800 & South Fork Saline River near Hot Springs & $\begin{array}{l}\text { Lat } 34^{\circ} 35^{\prime} 10^{\prime \prime}, \text { long } 92^{\circ} 58^{\prime} 11^{\prime \prime}, \text { SE } 1 / 4 \text { sec. } 6 \text {, T.2 S., } \\
\text { R. } 18 \text { W., at bridge on State Highway } 5,7.0 \text { miles northeast } \\
\text { of Hot Springs. }\end{array}$ \\
\hline 07362900 & North Fork Saline River near Benton & $\begin{array}{l}\text { Lat } 34^{\circ} 36^{\prime} 18^{\prime \prime} \text {, long } 92^{\circ} 37^{\prime} 67^{\prime \prime}, \text { SW } 1 / 4 \text { sec. } 28, \text { T. } 1 \mathrm{~S} \text {, } \\
\text { R. } 15 \text { W., at bridge on State Highway } 5,4.0 \text { miles northwest } \\
\text { of Benton. }\end{array}$ \\
\hline 07363180 & Lost Creek near Sheridan & $\begin{array}{l}\text { Lat } 34^{\circ} 18^{\prime} 52^{\prime \prime} \text {, long } 92^{\circ} 27^{\prime} 58^{\prime \prime}, \text { SE } 1 / 4 \text { sec. } 1 \text {, T. } 5 \text { S., } \\
\text { R. } 14 \text { W., at bridge on U.S. Highway } 270,4.0 \text { miles west of } \\
\text { Sheridan. }\end{array}$ \\
\hline 07363276 & Hurricane Creek near Ico & $\begin{array}{l}\text { Lat } 34^{\circ} 27^{\prime} 05^{\prime \prime} \text {, long } 92^{\circ} 22^{\prime} 18^{\prime \prime}, \mathrm{NE}, \mathrm{NE}, \text { sec. } 23 \text {, T.3 S., } \\
\text { R.13 W., at bridge on county road, } 1.2 \text { miles west of Ico. }\end{array}$ \\
\hline 07364060 & Bayou Lapile at Strong & $\begin{array}{l}\text { Lat } 33^{\circ} 06^{\prime} 53^{\prime \prime} \text {, long } 92^{\circ} 20^{\prime} 47^{\prime \prime}, \mathrm{N} 1 / 2 \mathrm{sec} .33 \text {, T. } 18 \mathrm{~S} . \text {, } \\
\text { R.12 W., at highway bridge } 0.5 \text { mile northeast of Strong. }\end{array}$ \\
\hline
\end{tabular}


analysis.-Continued

Thomas base-flow correlation methods (1985); G, graphical (Riggs, 1972)]

\begin{tabular}{|c|c|c|c|c|c|c|}
\hline Period of measurements & $\begin{array}{c}\text { Identifier } \\
\text { number } \\
\text { (figure 1, } \\
\text { plate 1, } \\
\text { table 1) }\end{array}$ & $\begin{array}{c}\text { Number of } \\
\text { measurements }\end{array}$ & $\begin{array}{c}\text { Drainage } \\
\text { area } \\
\left(\mathrm{mi}^{2}\right)\end{array}$ & Method & $\begin{array}{l}\text { Index } \\
\text { station } \\
\text { number }\end{array}$ & $\begin{array}{l}\text { Index station } \\
\text { identifier } \\
\text { number } \\
\text { (figure 1, } \\
\text { plate 1, table 1) }\end{array}$ \\
\hline 7/1964 - 9/1967 & 147 & 9 & 40.7 & G & 07349430 & 69 \\
\hline $\begin{array}{l}\text { 11/1963 - 11/1966, } \\
8 / 1988\end{array}$ & 148 & 17 & 232 & $S$ & 07349430 & 69 \\
\hline $\begin{array}{l}\text { 10/1958 - 8/1963, } \\
9 / 1968\end{array}$ & 149 & 12 & 43.1 & $S$ & 07365800 & 74 \\
\hline $8 / 1960-9 / 1967$ & 150 & 14 & 121 & $\mathrm{~S}$ & 07356500 & 70 \\
\hline $\begin{array}{l}\text { 10/1958 - 8/1963, } \\
9 / 1968\end{array}$ & 151 & 12 & 43.1 & $\mathrm{~S}$ & 07365800 & 74 \\
\hline $10 / 1958-6 / 1966$ & 152 & 32 & 405 & G & 07362500 & 30 \\
\hline $8 / 1960-9 / 1967$ & 153 & 14 & 121 & $\mathrm{~S}$ & 07356500 & 70 \\
\hline $\begin{array}{l}\text { 8/1958 - 11/1962, 8/1966, } \\
7 / 1974-11 / 1983,7 / 2002-2 / 2006\end{array}$ & 154 & 16 & 102 & S & 07356500 & 70 \\
\hline 8/1958 - 8/1963 & 155 & 18 & 12.5 & $\mathrm{~S}$ & 07356500 & 70 \\
\hline $9 / 1957-10 / 1963$ & 156 & 18 & 133 & G & 07356500 & 70 \\
\hline 10/1957 - 7/1964 & 157 & 8 & 932 & $S$ & 07363500 & 196 \\
\hline $7 / 1964$ - 9/1967 & 158 & 4 & 67.9 & G & 07363400 & 195 \\
\hline $\begin{array}{l}7 / 1964-8 / 1965 \\
9 / 1987-10 / 1989\end{array}$ & 159 & 9 & 88.8 & G & 07363400 & 195 \\
\hline $\begin{array}{l}10 / 1965-9 / 1967 \\
6 / 1963-11 / 1964 \\
9 / 1987-10 / 1989 \\
10 / 1958-8 / 1965\end{array}$ & 160 & 18 & 88.8 & $S$ & 07349430 & 69 \\
\hline
\end{tabular}


An assumption for the graphical technique is that the moments, such as the estimated skew and standard deviation, of the log Pearson Type III distribution transfer from the index stations to the partial-record stations. Additionally, the $Q_{7,2}$ and $Q_{7,10}$ characteristics for the selected index station had to be greater than zero.

\section{Methods of Analysis at Ungaged Basins}

Two types of regression analysis were used in this study to regionalize low-flow characteristics based upon data observed at continuous-streamflow record gaging stations and partial-record stations. Logistic regression was used to estimate the probability of an annual minimum flow at a site being zero and weighted least-squares regression was used to estimate the $Q_{7,10}$ values. The independent variables in both models are the basin attributes.

\section{Regional Regression Models for Low-Flow Characteristics}

Many streams in Arkansas experience zero flow as their minimum flow each year. A logistic regression model was used to estimate the probability of an annual $d$-day low-flow, such as the annual $\mathrm{Q}_{7}$, equal to zero at an ungaged location (Hortness, 2006; Bent and Steeves, 2006; Ludwig and Tasker, 1993). The form of the logistic regression model is given by:

$$
p_{\text {zero }}=1-\left(\frac{e^{\hat{\beta}_{o}+\hat{\beta}_{1} \log _{10}\left(x_{1}\right)+\ldots+\hat{\beta}_{k} \log _{10}\left(x_{k}\right)}}{1+e^{\hat{\beta}_{o}+\hat{\beta}_{1} \log _{10}\left(x_{1}\right)+\ldots+\hat{\beta}_{k} \log _{10}\left(x_{k}\right)}}\right)
$$

where

$$
\begin{aligned}
& p_{\text {zero }} \quad \text { is the probability of the annual d-day low } \\
& \text { flow being zero, } \\
& k \quad \text { is the number of basin attributes, } \\
& \begin{array}{r}
\hat{\beta}_{0}, \hat{\beta}_{1}, \hat{\beta}_{k} \quad \begin{array}{l}
\text { is the value of the kth basin attribute, and } \\
\text { are the coefficients determined by }
\end{array} \\
\text { maximizing the log-likelihood } \\
\text { function (described in more detail in }
\end{array} \\
& \text { appendix 2). }
\end{aligned}
$$

On one hand, if $p_{\text {zero }}$ was greater than the non-exceedence probability ( $=1 / T$, where $T$ is the return period of interest), a low-flow characteristic of interest, such as the $\mathrm{Q}_{7,10}$, was set to equal $0 \mathrm{ft}^{3} / \mathrm{s}$. On the other hand, if $p_{\text {zero }}$ was less than the nonexceedence probability, an estimate of the low-flow characteristic was calculated by a multiple linear regression model using a weighted least squares (WLS) parameter fit.

The form of the multiple linear regression model used was:

$\log _{10}\left(Q_{d-d a y, T-\text { year }}\right)=\hat{\beta}_{0}+\hat{\beta}_{1} \log _{10}\left(x_{1}\right)+\ldots+\hat{\beta}_{k} \log _{10}\left(x_{k}\right)+v$

where

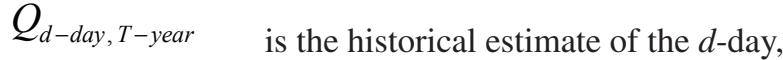

$$
\begin{aligned}
& \hat{\beta}_{0}, \hat{\beta}_{1}, \hat{\beta}_{k} \quad T \text {-year low flow, } \\
& \text { model using a modified WLS } \\
& \text { parameter fitting approach by } \\
& \text { Tasker (1980), and } \\
& v \quad \text { is the sum of the model error and } \\
& \text { time-sampling errors (appendix } \\
& \text { 2). }
\end{aligned}
$$

The conventional weights of WLS by Tasker (1980) apply only to continuous-streamflow record gaging stations and not to the partial-record stations, so a modified WLS approach was used to properly weight both types of stations (appendix 2).

In addition to performing regression analyses on the data for streams in each region, an analysis also was performed for the entire State. Several times these analyses yielded "statewide" regression models that were better (lower error statistics) than the regional models. When this was the case, or if there were insufficient data for no-flow events in a region, the statewide regression model was used in place of a regression model specific to that region.

\section{Basin Attributes Considered}

The low-flow characteristics of streams are directly related to the physical properties of the drainage basin. In most instances, drainage area is considered to be the predominant factor in explaining streamflow variability. Variations in low-flow yields can be closely associated with physiography (Hines, 1975). For example, drainage basins that are underlain by substrata that have high permeability and porosity almost always have greater base flows than basins that are underlain by substrata with low permeability and porosity. A variable that explains a substantial amount of the variability in lowflow characteristics is the base-flow recession time constant, tau $(\tau)$, and can be estimated at partial-record gaging stations (Eng and Milly, 2007).

Other factors such as precipitation, soil hydrologic group, forest cover, basin slope, land use, and basin length (described in appendix 3) could substantially affect low-flow variability. In total, a group of 75 basin attributes (table 3 ) was tested for statistical significance in regression models.

\section{Basin Attribute Selection}

Each of the 75 basin attributes was examined for moderate correlation to other attributes $(p>0.5)$ by Pearson correlations (Helsel and Hirsch, 2002). If a moderate correlation existed among two basin attributes, one was eliminated from consideration in the study (appendix 4). A set of basin attributes was selected to form the final regression model when they were found to be statistically significant $(p<0.05)$ (appendix 4). 
Table 3. Basin attributes tested for significance in the regression analysis.

[WMS, Watershed Modeling System; NAVD 88, North American Vertical Datum of 1988; NLCD, National Land Cover Dataset; GIS, Geographic Information System; PRISM, Parameter-elevation Regressions on Independent Slopes Model (Prism Group, Oregon Climatic Service of Oregon State University); STATSGO, State Soil Geographic (Schwartz and Alexander, 1995; U.S. Department of Agriculture, 2001); Kn, Nacatoch Sand; Kt, Trinity Formation; Kto, Tokio Formation; Tw, Wilcox Group]

\section{Physical Metrics (WMS)}

Drainage area (square miles)

Basin slope (foot/foot or mile/mile)

Overland flow (mile)

Percent facing north (percent)

Percent facing south (percent)

Maximum flow distance (mile)

Maximum flow slope (foot/foot or mile/mile)

Maximum stream length (mile)

Maximum stream slope (foot/foot or mile/mile)

Basin length (mile)

Effective basin width (mile)

Basin shape factor (dimensionless)

Basin perimeter (mile)

Basin sinuosity factor

Basin average elevation (feet, NAVD 88)

\section{Landcover Characteristics (NLCD using GIS)}

Deciduous forest (percent)

Evergreen forest (percent)

Mixed forest (percent)

Total forest (percent)

Pasture/hay (percent)

Row crops (percent)

\section{Precipitation, at stream-gaging station location (PRISM using GIS)}

Precipitation 1971-2000, at gage, Mean annual (inches)

Precipitation 1971-2000, November at gage, Mean monthly (inches)

Precipitation 1971-2000, December at gage, Mean monthly (inches)

Precipitation 1971-2000, January at gage, Mean monthly (inches)

Precipitation 1971-2000, February at gage, Mean monthly (inches)

Precipitation 1971-2000, March at gage, Mean monthly (inches)

Precipitation 1971-2000, April at gage, Mean monthly (inches)

Precipitation 1971-2000, November-December at gage, Mean seasonal (inches)

Precipitation 1971-2000, January-February at gage, Mean seasonal (inches)

Precipitation 1971-2000, March-April at gage, Mean seasonal (inches) 
Table 3. Basin attributes tested for significance in the regression analysis.-Continued

[WMS, Watershed Modeling System; NAVD 88, North American Vertical Datum of 1988; NLCD, National Land Cover Dataset; GIS, Geographic Information System; PRISM, Parameter-elevation Regressions on Independent Slopes Model (Prism Group, Oregon Climatic Service of Oregon State University); STATSGO, State Soil Geographic (Schwartz and Alexander, 1995; U.S. Department of Agriculture, 2001); Kn, Nacatoch Sand; Kt, Trinity Formation; Kto, Tokio Formation; Tw, Wilcox Group]

\section{Precipitation, at stream-gaging station location (PRISM using GIS)—Continued}

Precipitation 1961-1990 at gage, Mean annual (inches)

Precipitation 1961-1990, November at gage, Mean monthly (inches)

Precipitation 1961-1990, December at gage, Mean monthly (inches)

Precipitation 1961-1990, January at gage, Mean monthly (inches)

Precipitation 1961-1990, February at gage, Mean monthly (inches)

Precipitation 1961-1990, March at gage, Mean monthly (inches)

Precipitation 1961-1990, April at gage, Mean monthly (inches)

Precipitation 1961-1990, November-December at gage, Mean seasonal (inches)

Precipitation 1961-1990, January-February at gage, Mean seasonal (inches)

Precipitation 1961-1990 March-April at gage, Mean seasonal (inches)

\section{Precipitation, drainage basin average (PRISM using GIS)}

Precipitation 1971-2000, basin average, Mean annual (inches)

Precipitation 1971-2000, November basin average, Mean monthly (inches)

Precipitation 1971-2000, December basin average, Mean monthly (inches)

Precipitation 1971-2000, January basin average, Mean monthly (inches)

Precipitation 1971-2000, February basin average, Mean monthly (inches)

Precipitation 1971-2000, March basin average, Mean monthly (inches)

Precipitation 1971-2000, Aprilil basin average, Mean monthly (inches)

Precipitation 1971-2000, November-December basin average, Mean seasonal (inches)

Precipitation 1971-2000, January-February basin average, Mean seasonal (inches)

Precipitation 1971-2000, March-April basin average, Mean seasonal (inches)

Precipitation 1971-2000, November-April basin average, Mean seasonal (inches)

Precipitation 1961-1990, basin average, Mean annual (inches)

Precipitation 1961-1990, November basin average, Mean monthly(inches)

Precipitation 1961-1990, December basin average, Mean monthly (inches)

Precipitation 1961-1990, January basin average, Mean monthly (inches)

Precipitation 1961-1990, February basin average, Mean monthly (inches)

Precipitation 1961-1990, March basin average, Mean monthly (inches)

Precipitation 1961-1990, April basin average, Mean monthly (inches)

Precipitation 1961-1990, November-December basin average, Mean seasonal (inches)

Precipitation 1961-1990, January-February basin average, Mean seasonal (inches)

Precipitation 1961-1990 March-April basin average, Mean seasonal (inches)

Precipitation 1961-1990, November-April basin average, Mean seasonal (inches) 
Table 3. Basin attributes tested for significance in the regression analysis.-Continued

[WMS, Watershed Modeling System; NAVD 88, North American Vertical Datum of 1988; NLCD, National Land Cover Dataset; GIS, Geographic Information System; PRISM, Parameter-elevation Regressions on Independent Slopes Model (Prism Group, Oregon Climatic Service of Oregon State University); STATSGO, State Soil Geographic (Schwartz and Alexander, 1995; U.S. Department of Agriculture, 2001); Kn, Nacatoch Sand; Kt, Trinity Formation; Kto, Tokio Formation; Tw, Wilcox Group]

\section{Soil Characteristics STATSG0}

Soil permeability (inches/hour)

Soil drainage (dimensionless)

Soil hydrologic group (dimensionless)

Surficial Geology (Arkansas Geology Map (Haley and others, 1976))

Percent Mississippian (percent)

Percent Ordovician (percent)

Percent Mississippian and Ordovician (percent)

Percent Mississippian, Ordovician, Kn, Kt, Kto and Tw (percent)

Tau, Baseflow Recession Constant (Ken Eng, with GIS using kriging interpolation to develop GIS raster grid)

Tau annual (days)

Tau annual (days)

Tau, November-December (days)

Tau, January-February (days)

Tau, March-April (days) 


\section{Base-Flow Recession Constant, tau $(\tau)$}

Boussinesq (1903) formulated the idealized problem of outflow from a horizontal, unconfined aquifer discharging into a fully penetrating stream. Brutsaert and Nieber (1977) showed that several available solutions of the Boussinesq problem follow the general power relation:

$$
\frac{d Q}{d t}=-a Q^{b}
$$

where

$$
\begin{aligned}
Q & \text { is streamflow, } \\
t & \text { is time, and } \\
a \text { and } b & \text { are constants. }
\end{aligned}
$$

For application to the low-flow problem addressed herein only the large-time behavior was analyzed, which is generally associated with a value of b equal to 1 (Brutsaert and Lopez, 1998; Eng and Brutsaert, 1999). For large-time solution, a is given by:

$$
a=\frac{1}{\tau}=\frac{\pi^{2} K p d L_{s}^{2}}{f A^{2}}
$$

and thus;

$$
Q_{t+\Delta t}=Q_{t} e^{-\Delta t / \tau}
$$

where

$\begin{array}{cl}Q_{t} & \text { is the streamflow at time } t, \\ \Delta t & \text { is change in time, } \\ Q_{t+\Delta t} & \text { is the streamflow at time } t+\Delta t \\ \tau & \text { is the reciprocal of } a \text { (see equation } 4), \\ K & \text { is the hydraulic conductivity, } \\ f & \text { is the drainable porosity, } \\ d & \text { is the aquifer thickness, } \\ L_{s} & \text { is the upstream strenght lenght, } \\ A & \text { is the drainage area, and } \\ p & \text { is approximately 0.3465 (Brutsaert and } \\ & \quad \text { Nieber, 1977). }\end{array}$

The parameter $\tau$ is a long-term base-flow-recession time constant, which characterizes the rate of recession of base flow (Brutsaert and Lopez, 1998; Eng and Brutsaert, 1999). Instead of using equation (5), an effective value of $\tau$ can be calculated from daily streamflow measurements by use of equation (6) for partial-record and continuous-streamflow record gaging stations (Eng and Milly, 2007). For continuous-streamflow record gaging stations, an empirical Monte Carlo approach was used to identify 400 pairs of days. The associated daily streamflow measurements for these days were then used to calculate $400 \tau$ values by equation (6) for each continuousstreamflow record gaging station. Because the sampling strat- egy for existing data in the partial-record network of Arkansas was not suitable for use in the methods described by Eng and Milly (2007), their method was only applied to the continuousstreamflow record gaging stations, and a kriged map (figs. 3-6) of mean $\tau$ values was developed from them. From the kriged maps, a $\tau$ value can be determined for any stream in the State except for eastern Arkansas (not included in the study area) and used in the regression models. $\tau$ is assumed to be mostly spatially dependent for a kriged map, which is not necessarily true, but a map was needed to spatially distribute the $\tau$ data for use in the regression models.

The $\tau$ values are seasonally dependent because they are derived from discharge records from recession periods that are affected by evapotranspiration (Brutsaert, 1982; Zecharias and Brutsaert, 1988; Brutsaert, 2005). To examine if the seasonality of $\tau$ values affects the estimates of low-flow characteristics, average 2-month $\tau$ values were calculated and used as potential predictor variables in conventional multiple linear regression models. Recession flows during periods that were completely within the November to December, January to February, and March to April periods were used to compute seasonal $\tau$ values.

\section{Performance Metrics for Evaluation of Regression Models}

The potential effect of the basin attributes on the coefficients of the regression model can be measured by the leverage statistic. This statistic is based upon basin attribute information, period of record, mean, standard deviation and skew of the annual series, and the log-Pearson Type III deviate, so it can be calculated before the regression model is formed. For WLS regression, it can be given by:

$$
h=X\left(X^{T} W^{-1} \mathbf{X}\right)^{-1} \quad X^{T} W^{-1}
$$

where

$$
\begin{aligned}
& \mathbf{h} \text { is the matrix containing the leverage values } \\
& \text { for all basins, } \\
& \mathbf{X} \text { is the matrix of all basin attributes at all basins } \\
& \text { in the regression augmented by a column } \\
& \text { of ones, } \\
& \mathbf{T} \text { is the transpose of a matrix, and } \\
& \mathbf{W} \text { is the WLS weighting matrix. }
\end{aligned}
$$

For a basin's attributes to have large effect on the determination of the coefficients of a regression model it must be equal to or greater than the leverage threshold that is given by:

$$
h_{\text {lim it }}=\frac{2 \sum_{i=1}^{n} h_{i i}}{n}
$$




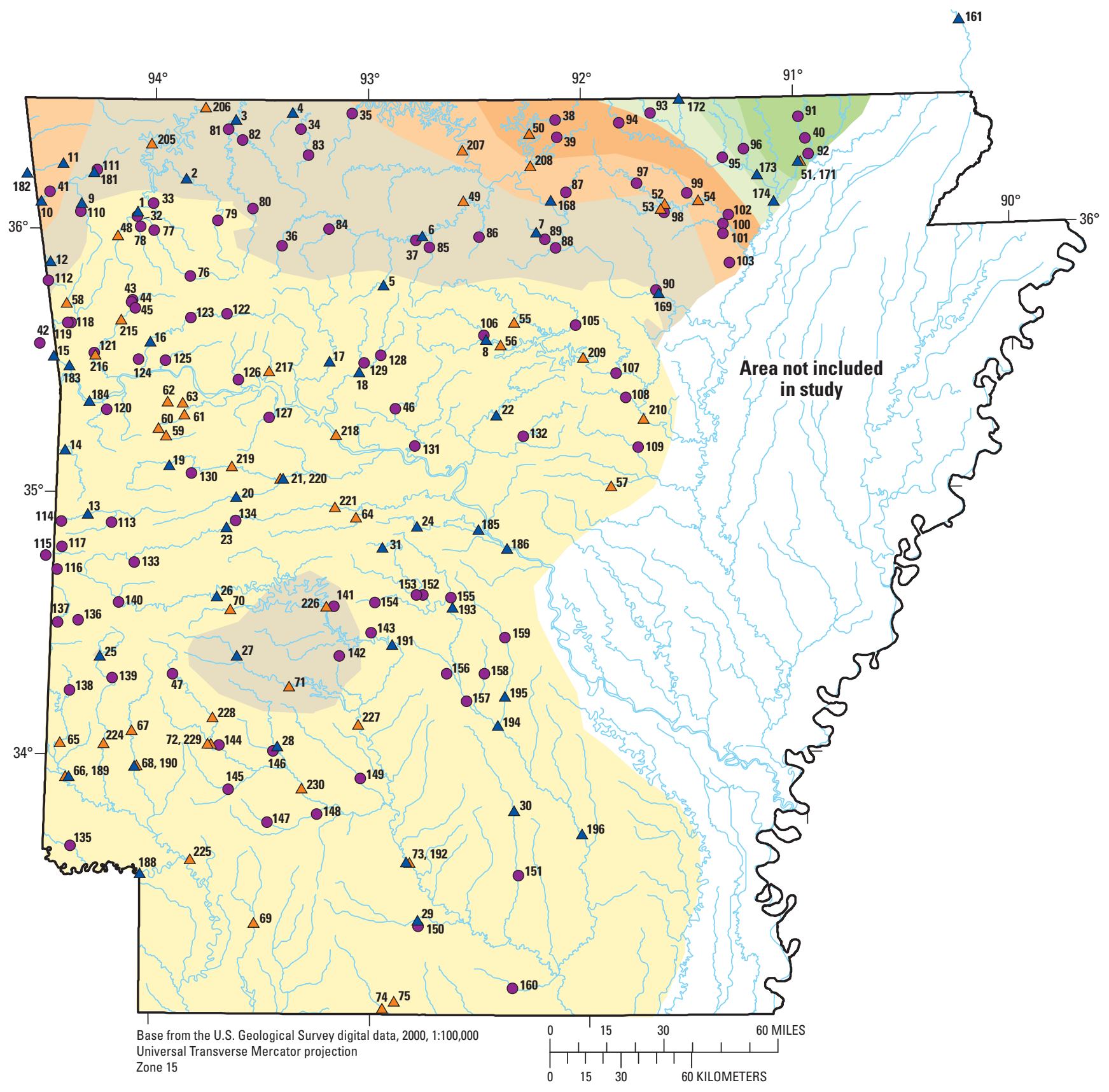

EXPLANATION

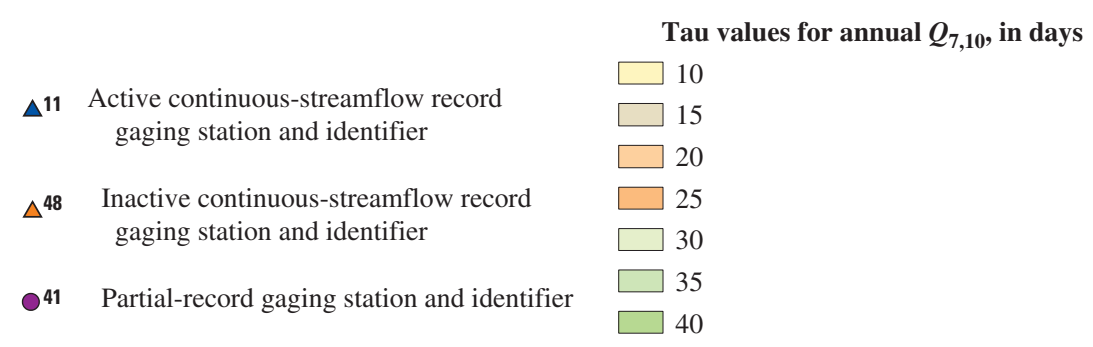

Figure 3. Geographic distribution of tau values for the annual $Q_{7,10^{\circ}}$ 


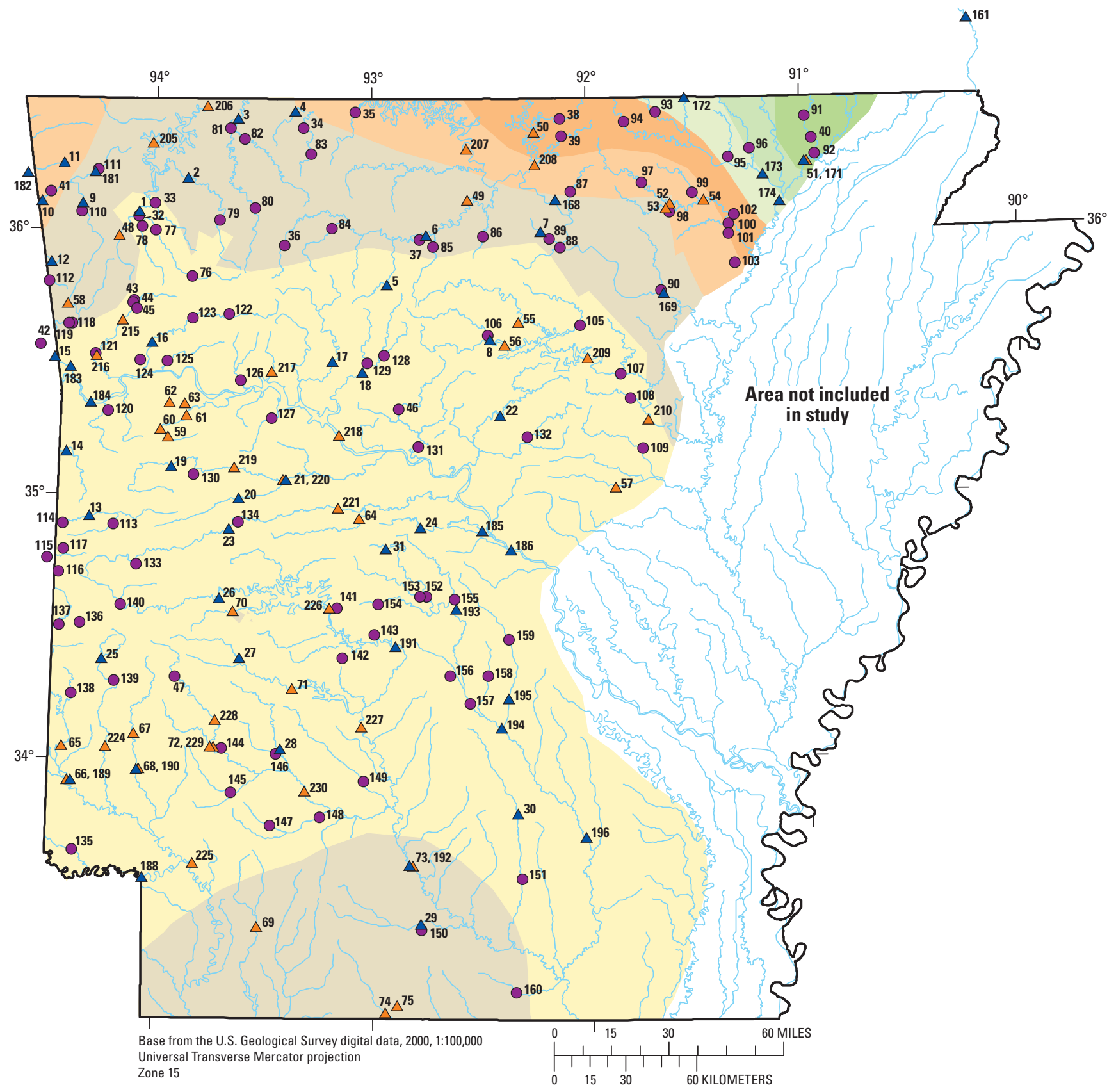

EXPLANATION

Tau values for November through December

$\Delta^{11} \quad$ Active continuous-streamflow record $Q_{7,10}$, in days gaging station and identifier

$\triangle^{48} \quad$ Inactive continuous-streamflow record gaging station and identifier

41 Partial-record gaging station and identifier

Figure 4. Geographic distribution of tau values for the November through December $0_{7,10^{\circ}}$ 


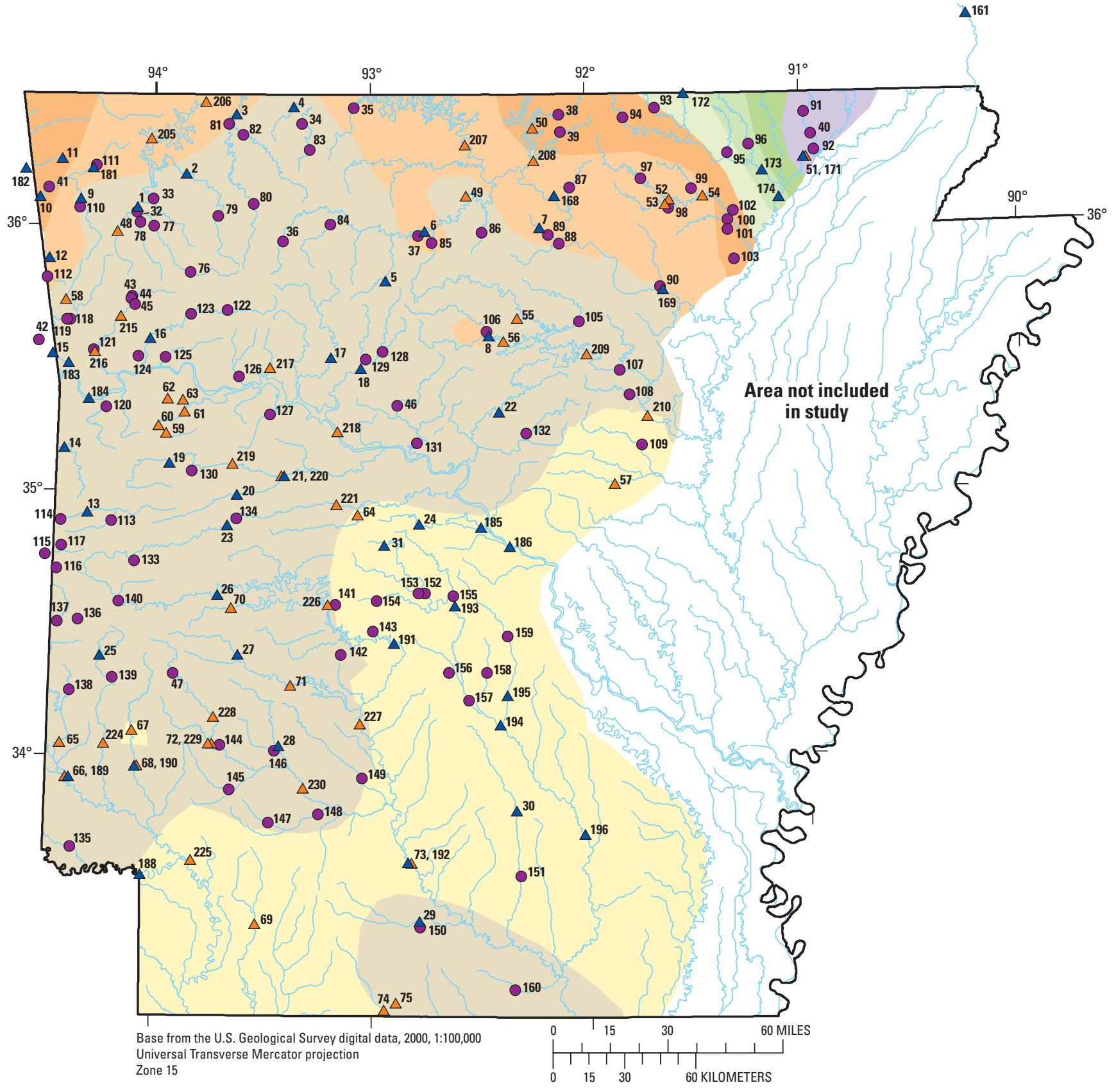

EXPLANATION

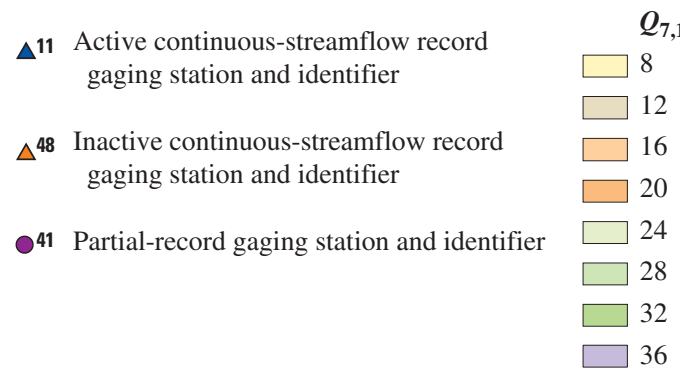

Tau values for January through February $Q_{7,10}$, in days 


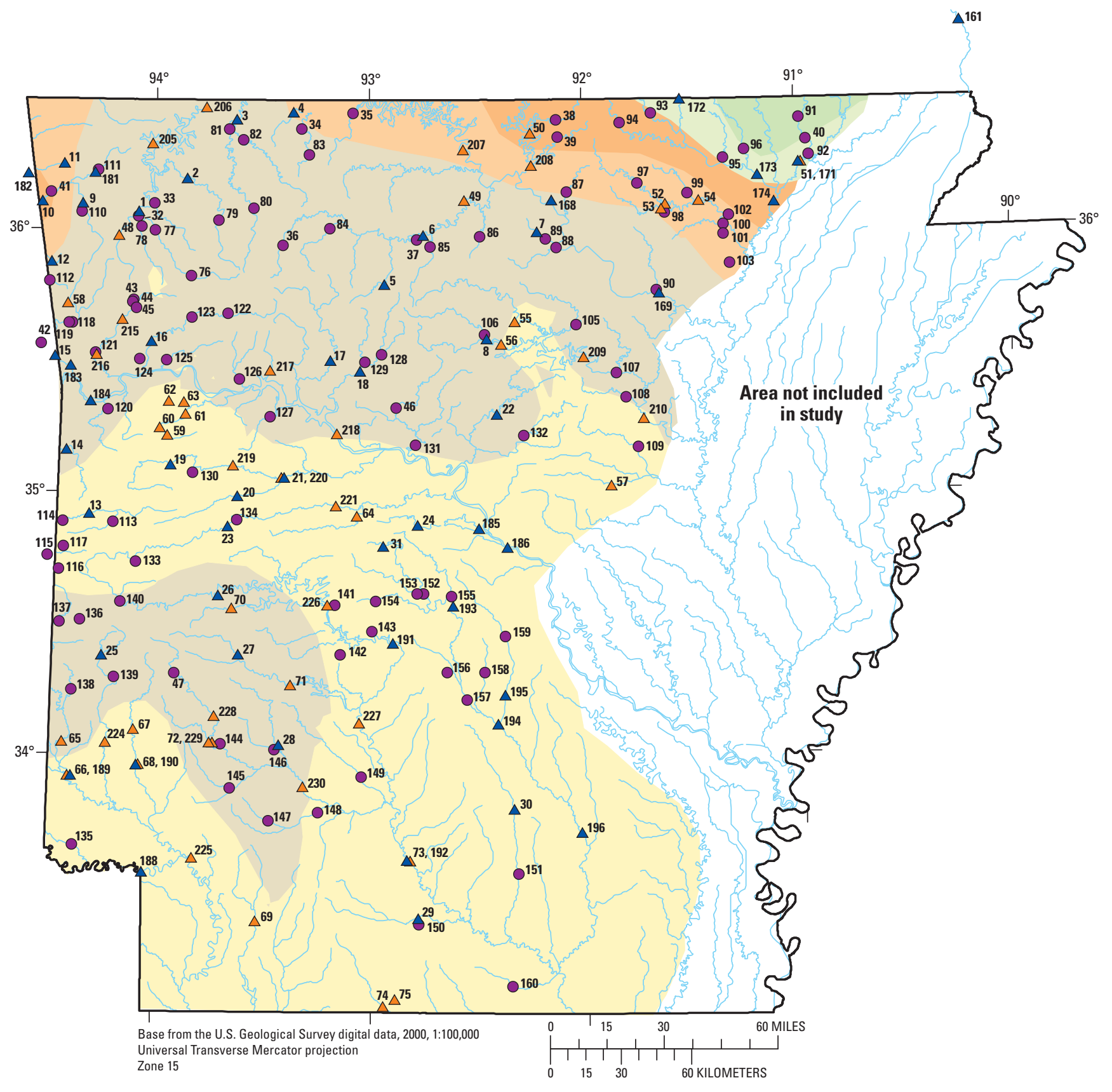

EXPLANATION

$\begin{array}{ll}\Delta^{\mathbf{1 1}} \text { Active continuous-streamflow record } & \boldsymbol{Q}_{\mathbf{7 , 1 0}} \\ \text { gaging station and identifier } & \square 8 \\ & \square 12 \\ \Delta^{\mathbf{4 8}} \begin{array}{l}\text { Inactive continuous-streamflow record } \\ \text { gaging station and identifier }\end{array} & \square 16 \\ & \square 20 \\ \mathbf{A}^{\mathbf{4 1}} \text { Partial-record gaging station and identifier } & \square 24 \\ & \square 28\end{array}$

Figure 6. Geographic distribution of tau values for the March through April $Q_{7,10^{\circ}}$ 
where

$$
\begin{array}{cc}
n \quad \begin{array}{c}
\text { is the number of basins in the regression } \\
\text { model, and } \\
\text { are the main diagonal compoents of the } \mathbf{h} \\
\text { matrix from equation } 7 .
\end{array}
\end{array}
$$

Basins whose leverage values exceed the limit given by equation 8 were removed to evaluate the effect on the coefficients of the regression model. If the coefficients changed by more than 20 percent from their original values, the basin was removed. If not, the basin was retained in the regression model. The removed basins also were checked to see if some previously unknown alteration to the watershed had occurred.

The performance of the two types of regression models was evaluated using different methods. The performance of the logistic regression models was evaluated using the percentage of basins incorrectly estimated to have zero flow (misclassification percentage). The evaluation metric for the conventional WLS multiple linear regression models was the average variance of prediction (Tasker and Stedinger, 1986), AVP, modified for use for WLS regression and given by:

$$
A V P=\sigma_{\delta}^{2}+\left(\frac{1}{n}\right) \sum_{i=1}^{n} \mathbf{x}_{i}\left(\mathbf{X}^{T} \mathbf{W}^{-1} \mathbf{X}\right)^{-1} \mathbf{x}_{i}^{T}
$$

where

$$
\begin{gathered}
\sigma_{\delta}^{2} \\
n \\
\text { is the model error variance, } \\
\text { model, and } \\
\mathbf{x}_{i} \quad \begin{array}{c}
\text { is the vector containing the basin attribues of } \\
\text { the } i^{\text {th }} \text { basin augmented by a value of one. }
\end{array}
\end{gathered}
$$

The conventional performance metric based on the $A V P$ is the average standard error of prediction, $S_{p}$, which is an error reported as a percent of the observed value. The $S_{p}$ metric is given by (Aitchison and Brown, 1957, modified for use of common logarithms):

$$
S_{p}=100\left[e^{(\ln 10)^{2} A V P}-1\right]^{0.5}
$$

In addition to the $S_{p}$ metric, the amount of variability accounted for by the regression model for the estimated lowflow characteristic is calculated by the pseudo $R^{2}$ metric. The pseudo $R^{2}$ metric is a more suitable metric than the conventional and adjusted $R^{2}$ metrics for weighted and generalized least squares regression models (Griffis and Stedinger, 2007), because unlike the conventional and adjusted $R^{2}$ metrics, the pseudo $R^{2}$ measures the amount of variability accounted for only by the model. Pseudo $R^{2}$ is given by (Griffis and Stedinger, 2007):

$$
\text { Pseudo } R^{2}=1-\frac{\sigma_{k}^{2}}{\sigma_{o}^{2}}
$$

where

$$
\begin{array}{cc}
\sigma_{o}^{2} & \text { is the model error variance of a constant } \\
\text { regression model, and } \\
\sigma_{k}^{2} & \text { is the model error variance for a regression } \\
\text { model containing the final } k \text { predictors. }
\end{array}
$$

\section{Low-Flow Characteristics at Continuous-Streamflow and Partial- Record Gaging Stations}

In general, $\mathrm{Q}_{7,10}$ and $\mathrm{Q}_{7,2}$ (tables 4 and 5, located at end of the report) values were lowest during August through September. Streams that were located in large basins and highly regulated generally had higher $\mathrm{Q}_{7,10}$ and $\mathrm{Q}_{7,2}$ values than streams that were located in small, unregulated streams. Often, unregulated streams with drainage areas less than $100 \mathrm{mi}^{2}$ experienced $\mathrm{Q}_{7,10}$ values of $0.0 \mathrm{ft}^{3} / \mathrm{s}$, particularly in the Boston Mountains and Arkansas Valley physiographic sections (fig.

7).

\section{Regionalization of Low-Flow Characteristics}

A regression analysis was used to develop regional flow models that related basin characteristics and precipitation to low-flow characteristics at continuous-streamflow record gaging stations and partial-record gaging stations in Arkansas. These regional flow models, subsequently presented herein, can be used to estimate low-flow characteristics at any desired location on streams in the study area.

\section{Low-Flow Regions of the State}

Hines (1975) first associated physiographic areas of the State with corresponding low-flow yields from the streams in Arkansas. For regionalization purposes, Ludwig and Tasker (1993) divided the western two-thirds of the State into three low-flow regions of well sustained and poorly sustained flow. This subdivision was further supported by the regression models in each region for Ludwig and Tasker (1993). Minor changes to Region 2 were made because of enhanced geographical information systems capabilities, but for the most part, they remained the same for this report (plate 1). 


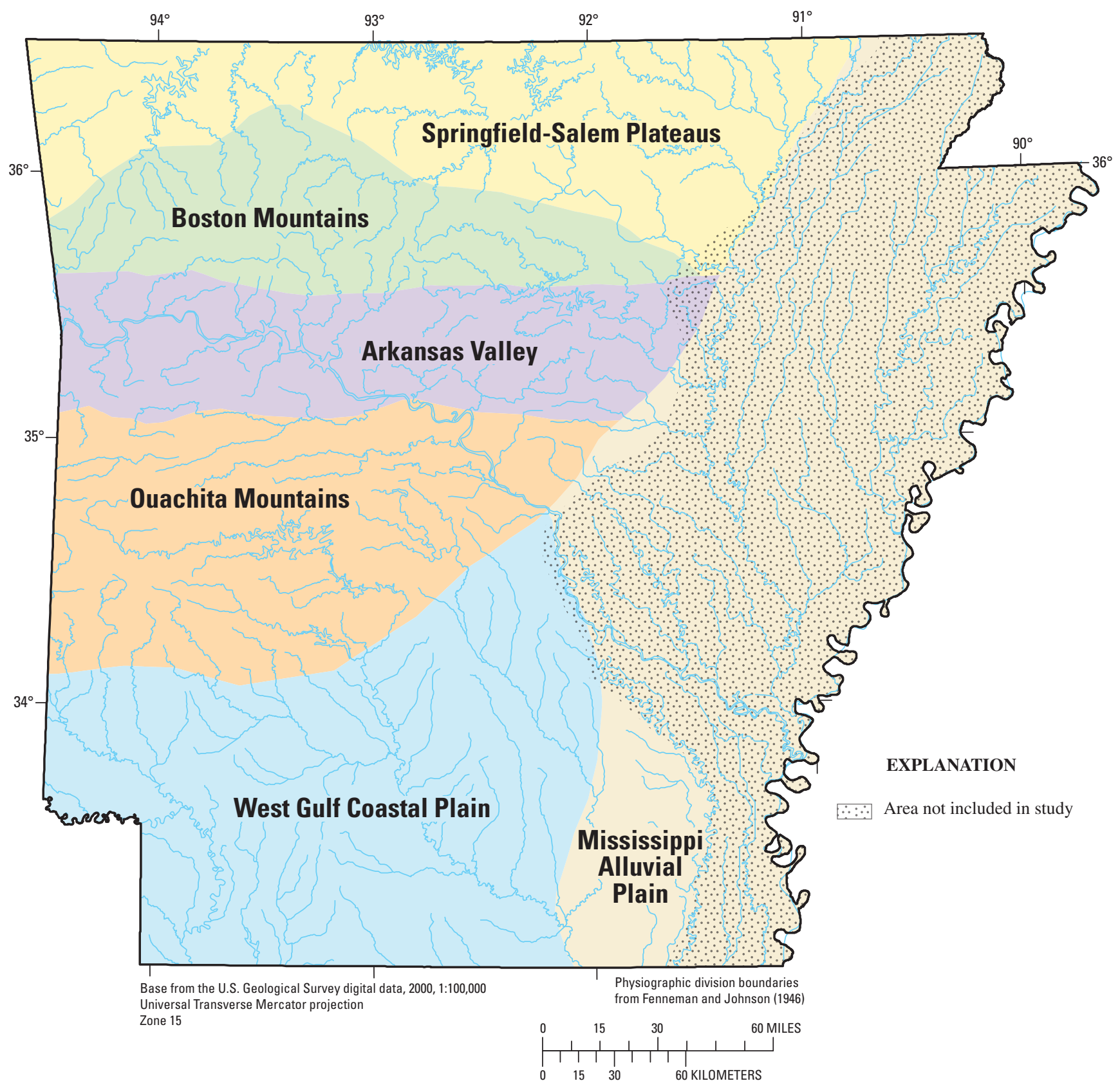

Figure 7. Physiographic sections of Arkansas. 
Region 1 encompasses most of the upper White River Basin and parts of the Arkansas River Basin in Arkansas. The region is underlain by a series of limestone units, and, because of this, exhibits numerous characteristics of karst terrain (Ludwig and Tasker, 1993). Streams in the region are sustained by discharges from numerous springs, which are issued from a well-developed system of solution channels. The wellsustained nature of the spring flow is indicative of a regional source of ground water that is supplemented during extended periods of precipitation by a local component of flow.

Region 2 includes two separate areas that are geologically and physiographically different but are similar with respect to base flow. The northern area of this region includes the Boston Mountains, Arkansas Valley, and the northern part of the Ouachita Mountains physiographic sections (Fenneman and Johnson, 1946) (fig. 7). These sections are composed of densely consolidated sandstone and shale deposits. Because only small amounts of ground water are available from the joints and fractures in these sections, many of the streams in this area recede to zero flow each year.

The southern part of Region 2 lies within the West Gulf Coastal Plain physiographic section (Fenneman and Johnson, 1946; Ludwig and Tasker, 1993). The area is underlain by consolidated deposits of sand, silt, and clay. The streams in this area generally do not have sustained base flow because, in part, the stream channels are not incised deeply enough to intercept the water table, and, in part, because the surficial deposits have low permeability and porosity.

Region 3 lies in the southern Ouachita Mountains and extends southward into the West Gulf Coastal Plain. It includes much of the upper Ouachita River Basin and parts of the Red River Basin. Base flows within the Ouachita Mountain section are derived from formations that are composed primarily of fine-grained sandstone and chert deposits. These formations typically have high porosity and permeability, which enhances the recharge potential of the rocks. Base flows within the Coastal Plain section are derived as surplus recharge from the productive aquifers in the area including the Sparta Sand and the Nacatoch Sand.

\section{Low-Flow Characteristics at Ungaged Basins}

The basin attribute selection procedures applied to the 75-candidate basin attributes resulted in 15 that were determined to be statistically significant in the logistic and WLS regression models (appendix 4; table 4-2). No more than three basin attributes were allowed to enter any of the regression models. Despite the amount of error introduced by kriging , it was found statistically significant $(p<0.05)$ in all the logistic regression models and in the majority of the WLS regression models.

Basins with leverage values that exceeded the $h_{\text {limit }}$, and affected the coefficients of either the logistic or WLS regression model were removed from that regression model and are listed in appendix 2, table 2-1. Table 6 contains the final logistic regression models and associated performance metrics (misclassification percentage) for each low-flow characteristic of interest. The $p_{\text {zero }}$ values for seasonal low-flow characteristics are generally more accurate than the $p_{\text {zero }}$ values for the annual ones except in Region 2. The only basin attribute to appear in all logistic regression models was $\tau$, which indicates its importance in estimating $p_{\text {zero }}$ values.

The final WLS regression models and their associated performance metrics (Pseudo $R^{2}$ and $S_{p}$ ) are presented in table 7. The list of continuous-streamflow record and partial-record gaging stations used within each of the three region's sets of regression models is located in table 8. For Regions 2 and 3, the annual low-flow characteristics inherently have larger $S_{p}$ and lower Pseudo $R^{2}$ values than those for the seasonal lowflow characteristics. In Region 1, the amount of error among the seasonal and annual low-flow characteristics is roughly equivalent. These differences among the annual and seasonal low-flow characteristics are mainly because of the varying amount of sustained base flow during different parts of the climatic year. The computed low-flow characteristics of basins in Region 1 generally are much larger on average than those in Regions 2 and 3 indicating that basins in Region 1 have longer periods of sustained base flow. The differences in the annual and seasonal analysis in Regions 2 and 3 indicate that the basins in these regions have more variation in the amount of sustained base flow than in Region 1. In general, the period of the climatic year from November to April is not when the lowest recorded daily flows occur in Arkansas, so the basins during this period have larger sustained base flows. The increase in the performance of the WLS regression models for the bimonthly and monthly low-flow characteristics over the annual models reflects the reduced variation in the base flows. For the WLS regression models, additional information, such as the average model error and the basins removed for each of the regions, is presented in appendix 2 .

The range of basin attribute values used to form the logistic models is listed in table 9. The range for those attributes used to form the multiple linear regression models using a WLS parameter fitting estimation are listed in table 10, which indicates appropriate ranges in values for application of the equations.

In addition to performing regression analyses on the data for streams in each region, an analysis also was performed for the entire State. Several times these analyses yielded "statewide" regression models that were better (lower error statistics) than the regional models. When this was the case, or if there were insufficient data for no-flow events in a region, the statewide regression model was used in place of a regression model specific to that region.

\section{Use of Regression Models}

Example calculations to demonstrate use of the regression models are described in this section. The examples show application of logistic and WLS models. 
Table 6. Logistic regression models and associated performance metrics (misclassification percentage) for each low-flow characteristic of interest.

$\left[{ }^{* *}\right.$, Insufficient annual events equal to zero cubic feet per second for individual equation; the statewide equation shown here is used for this calculation. $A$, area in square miles; $t_{\text {Annual }}$, tau annual, in days; $Q_{7}$, averaged consecutive 7-day minimum discharge; $Q_{7,10}, 7$-day, 10 -year low flow; $Q_{7,2}, 7$-day, 2 -year low flow; Ordo/Miss K, percent surficial geology as Ordovician and Mississippian rocks; --, no logistic regression model available for this low-flow characteristic]

Low-flow characteristic

Multiple linear weighted least squares (WLS) regression model

Misclassification

percentage

$Q_{7,2} \quad Q_{7,10}$

\section{Region 1}

Annual $Q_{7}$

$p_{\text {zero }}=1-\left(\frac{e^{-20.0+3.0 \log _{10}(A)+16.8 \log _{10}\left(\tau_{\text {Annual }}\right)}}{1+e^{-20.0+3.0 \log _{10}(A)+16.8 \log _{10}\left(\tau_{\text {Annual }}\right)}}\right)$

**November-April $Q_{7}$

$p_{\text {zero }}=1-\left(\frac{e^{-10.2+1.2 \log _{10}(A)+10.9 \log _{10}\left(\tau_{\text {Annual })}+1.0 \log _{10}(\text { Ordo } / \text { Miss } K+1)\right.}}{1+e^{-10.2+1.2 \log _{10}(A)+10.9 \log _{10}\left(\tau_{\text {Annual }}\right)+1.0 \log _{10}(\text { Ordo } / \text { Miss } K+1)}}\right)$

$* *$ November-December $Q_{7}$

$p_{\text {zero }}=1-\left(\frac{e^{-11.2+1.4 \log _{10}(A)+11.5 \log _{10}\left(\tau_{\text {Annual }}\right)+1.1 \log _{10}(\text { Ordo } / \text { Miss } K+1)}}{1+e^{-11.2+1.4 \log _{10}(A)+11.5 \log _{10}\left(\tau_{\text {Annual }}\right)+1.1 \log _{10}(\text { Ordo } / \text { Miss } K+1)}}\right)$

$* *$ November $Q_{7}$

$p_{\text {zero }}=1-\left(\frac{e^{-11.7+1.4 \log _{10}(A)+11.8 \log _{10}\left(\tau_{\text {Annual }}\right)+1.2 \log _{10}(\text { Ordo } / \text { Miss } K+1)}}{1+e^{-11.7+1.4 \log _{10}(A)+11.8 \log _{10}\left(\tau_{\text {Annual }}\right)+1.2 \log _{10}(\text { Ordo } / \text { Miss } K+1)}}\right)$

Region 2

Annual $Q_{7}$

$p_{\text {zero }}=1-\left(\frac{e^{-7.0+9.0 \log _{10}\left(\tau_{\text {Annual }}\right)}}{1+e^{-7.0+9.0 \log _{10}\left(\tau_{\text {Annual }}\right)}}\right)$

**November-April $Q_{7}$

$p_{\text {zero }}=1-\left(\frac{e^{-8.0+0.9 \log _{10}(A)+9.4 \log _{10}\left(\tau_{\text {Annual }}\right)}}{1+e^{-8.0+0.9 \log _{10}(A)+9.4 \log _{10}\left(\tau_{\text {Anпиа }}\right)}}\right)$

$* *$ November-December $Q_{7}$

$p_{\text {zero }}=1-\left(\frac{e^{-8.7+1.2 \log _{10}(A)+9.4 \log _{10}\left(\tau_{\text {Annual }}\right)}}{1+e^{-8.7+1.2 \log _{10}(A)+9.4 \log _{10}\left(\tau_{\text {Annual }}\right)}}\right)$

$* *$ November $Q_{7}$

$$
p_{\text {zero }}=1-\left(\frac{e^{-9.0+1.2 \log _{10}(A)+9.6 \log _{10}\left(\tau_{\text {Annual }}\right)}}{1+e^{-9.0+1.2 \log _{10}(A)+9.6 \log _{10}\left(\tau_{\text {Annual }}\right)}}\right)
$$

\section{Region 3}

Annual $Q_{7}$

$p_{\text {zero }}=1-\left(\frac{e^{-25.6+25.1 \log _{10}\left(\tau_{\text {Annual }}\right)+3.4 \log _{10}(\text { Ordo } / \text { Miss } K+1)}}{1+e^{-25.6+25.1 \log _{10}\left(\tau_{\text {Annual }}\right)+3.4 \log _{10}(\text { Ordo } / \text { Miss } K+1)}}\right)$

**November-April $Q_{7}$

$$
p_{\text {zero }}=1-\left(\frac{e^{-10.2+1.2 \log _{10}(A)+10.9 \log _{10}\left(\tau_{\text {Annual }}\right)+1.0 \log _{10}(\text { Ordo } / \text { Miss } K+1)}}{1+e^{-10.2+1.2 \log _{10}(A)+10.9 \log _{10}\left(\tau_{\text {Annual }}\right)+1.0 \log _{10}(\text { Ordo } / \text { Miss } K+1)}}\right)
$$


Table 6. Logistic regression models and associated performance metrics (misclassification percentage) for each low-flow characteristic of interest.-Continued

[**, Insufficient annual events equal to zero cubic feet per second for individual equation; the statewide equation shown here is used for this calculation. $A$, area in square miles; $t_{\text {wumal }}$, tau annual, in days; $Q_{7}$, averaged consecutive 7-day minimum discharge; $Q_{710}, 7$-day, 10 -year low flow; $Q_{72}$, 7-day, 2-year low flow; Ordo/Miss K, percent surficial geology as Ordovician and Mississippian rocks; --, no logistic regression model available for this low-flow characteristic]

\begin{tabular}{|c|c|c|}
\hline \multirow{2}{*}{ Low-flow characteristic } & \multirow{2}{*}{ Multiple linear weighted least squares (WLS) regression model } & $\begin{array}{c}\text { Misclassification } \\
\text { percentage }\end{array}$ \\
\hline & & $Q_{7,2}$ \\
\hline
\end{tabular}

Region 3-Continued

$* *$ November-December $Q_{7} \quad p_{\text {zero }}=1-\left(\frac{e^{-11.2+1.4 \log _{10}(A)+11.5 \log _{10}\left(\tau_{\text {Annual }}\right)+1.1 \log _{10}(\text { Ordo/Miss } K+1)}}{1+e^{-11.2+1.4 \log _{10}(A)+11.5 \log _{10}\left(\tau_{\text {Annual }}\right)+1.1 \log _{10}(\text { Ordo } / \text { Miss } K+1)}}\right) \quad 3.1$

**November $Q_{7}$

$$
p_{\text {zero }}=1-\left(\frac{e^{-11.7+1.4 \log _{10}(A)+11.8 \log _{10}\left(\tau_{\text {Annual }}\right)+1.2 \log _{10}(\text { Ordo } / \text { Miss } K+1)}}{1+e^{-11.7+1.4 \log _{10}(A)+11.8 \log _{10}\left(\tau_{\text {Annual }}\right)+1.2 \log _{10}(\text { Ordo } / \text { Miss } K+1)}}\right)
$$


Table 7. Multiple linear weighted least squares regression models for each region in Arkansas.

[**, Insufficient data for individual equation for region; the statewide equation shown here is used for this calculation. $Q_{7}$, averaged consecutive 7-day minimum discharge; $Q_{7,10}$, 7-day, 10-year low flow; $Q_{7,2}$, 7-day, 2-year low flow; Ordo/Miss $K$, percent surficial geology as Ordovician and Mississippian rocks; $\tau_{\text {Annual }}$, tau annual in days; SoilHydro, Soil Hydrologic Group; $\tau_{\text {Nov-Dec }}$, tau, November-December (days); $P_{\text {(Nov-Apr } 71-00}$, precipitation 1971-2000, November-April basin average, mean monthly (inches); $P_{\text {(Mar) 61-90, }}$, precipitation 1961-1990, March basin average, mean monthly (inches); $P_{\text {(Annual) 71-00, }}$, precipitation 1971-2000, basin average, mean monthly (inches); $P_{\text {(Nov-Dec) 61-90, }}$, precipitation 1961-1990, November-December basin average, mean monthly (inches); $\tau_{\text {(Mar-April) }}$, tau, March-April (days); $P_{(\text {Nov) }}$ 61-90, precipitation, 1961-1990, basin average, mean monthly (inches)]

\begin{tabular}{|c|c|c|c|}
\hline Low-flow characteristic & Multiple linear weighted least squares (WLS) regression model & $\begin{array}{c}\text { Pseudo-R } \\
\text { (percent) }\end{array}$ & $\underset{\text { (percent) }}{S_{p}}$ \\
\hline \multicolumn{4}{|c|}{ Region 1} \\
\hline Annual $Q_{7,2}$ & $\log _{10}\left(Q_{7,2}\right)_{\text {Annual }}=5.2+0.9 \log _{10}(A)-19.1 \log _{10}($ SoilHydro $)+0.8 \log _{10}($ Ordo/Miss K+1) & 68.6 & 107.0 \\
\hline Annual $Q_{7,10}$ & $\log _{10}\left(Q_{7,10}\right)_{\text {Annual }}=6.9+0.9 \log _{10}(A)-26.7 \log _{10}($ SoilHydro $)+1.3 \log _{10}($ Ordo/Miss K+1) & 54.4 & 236.7 \\
\hline November-April $Q_{7,10}$ & $\log _{10}\left(Q_{7,10}\right)_{\text {Nov-Apr }}=-2.6+0.9 \log _{10}(A)+0.8 \log _{10}($ Ordo/Miss $K+1)$ & 57.1 & 130.2 \\
\hline November-December $Q_{7,10}$ & $\log _{10}\left(Q_{7,10}\right)_{\text {Nov-Dec }}=-2.6+0.8 \log _{10}(A)+0.8 \log _{10}($ Ordo/Miss $K+1)$ & 56.7 & 129.6 \\
\hline January-February $Q_{7,10}$ & $\log _{10}\left(Q_{7,10}\right)_{\mathrm{Jan}-\mathrm{Feb}}=-1.8+0.9 \log _{10}(A)+0.4 \log _{10}($ Ordo/Miss $K+1)$ & 68.5 & 82.4 \\
\hline March-April $Q_{7,10}$ & $\log _{10}\left(Q_{7,10}\right)_{\mathrm{Mar}-\mathrm{Apr}}=-7.9+1.1 \log _{10}(A)+0.3 \log _{10}($ Ordo/Miss $K+1)+4.6 \log _{10}\left(P_{(\text {Nov-Apr }) 71-00}\right)$ & 80.7 & 55.5 \\
\hline November $Q_{7,10}$ & $\log _{10}\left(Q_{7,10}\right)_{\text {Nov }}=-2.5+0.9 \log _{10}(A)+0.8 \log _{10}($ Ordo/Miss $K+1)$ & 55.2 & 133.0 \\
\hline December $Q_{7,10}$ & $\log _{10}\left(Q_{7,10}\right)_{\mathrm{Dec}}=-2.0+0.9 \log _{10}(A)+0.5 \log _{10}($ Ordo/Miss $K+1)$ & 62.1 & 97.0 \\
\hline January $Q_{7,10}$ & $\log _{10}\left(Q_{7,10}\right)_{\mathrm{Jan}}=-1.8+0.9 \log _{10}(A)+0.5 \log _{10}($ Ordo/Miss $K+1)$ & 67.9 & 81.6 \\
\hline February $Q_{7,10}$ & $\log _{10}\left(Q_{7,10}\right)_{\mathrm{Feb}}=-8.4+1.1 \log _{10}(A)+0.2 \log _{10}($ Ordo/Miss $K+1)+5.0 \log _{10}\left(P_{(\text {Nov-Apr }) 71-00}\right)$ & 81.6 & 55.2 \\
\hline $\operatorname{March} Q_{7,10}$ & $\log _{10}\left(Q_{7,10}\right)_{\mathrm{Mar}}=-3.4+1.1 \log _{10}(A)+3.7 \log _{10}\left(P_{(\text {Mar }) 61-90}\right)$ & 76.9 & 58.1 \\
\hline April $Q_{7,10}$ & $\log _{10}\left(Q_{7,10}\right)_{\text {Apr }}=-6.8+1.1 \log _{10}(A)+4.2 \log _{10}\left(P_{(\text {Nov-Apr }) 71-00}\right)$ & 79.4 & 55.0 \\
\hline \multicolumn{4}{|c|}{ Region 2} \\
\hline Annual $Q_{7,2}$ & $\log _{10}\left(Q_{7,2}\right)_{\text {Annual }}=-7.1+1.1 \log _{10}(A)+4.4 \log _{10}\left(\tau_{\text {Annual }}\right)$ & 77.0 & 85.2 \\
\hline$* *$ Annual $Q_{7,10}$ & $\log _{10}\left(Q_{7,10}\right)_{\text {Annual }}=-9.6+1.1 \log _{10}(A)+4.0 \log _{10}\left(\tau_{\text {Annual }}\right)+1.8 \log _{10}\left(P_{\text {(Annual) } 71-00}\right)$ & 52.9 & 340.7 \\
\hline November-April $Q_{7,10}$ & $\log _{10}\left(Q_{7,10}\right)_{\text {Nov-Apr }}=-5.4+0.7 \log _{10}(A)+3.2 \log _{10}\left(P_{(\text {Nov-Dec } 61-90}\right)$ & 88.6 & 82.4 \\
\hline November-December $Q_{7,10}$ & $\log _{10}\left(Q_{7,10}\right)_{\text {Nov-Dec }}=-5.7+0.7 \log _{10}(A)+3.5 \log _{10}\left(P_{(\text {Nov-Dec) } 61-90}\right)$ & 85.7 & 87.9 \\
\hline **January-February $Q_{7,10}$ & $\log _{10}\left(Q_{7,10}\right)_{\mathrm{Jan}-\mathrm{Feb}}=-4.9+1.2 \log _{10}(A)+0.2 \log _{10}($ Ordo/Miss $K+1)+3.0 \log _{10}\left(P_{\text {(Nov-Apr) 61-90 }}\right)$ & 96.6 & 31.3 \\
\hline$* *$ March-April $Q_{7,10}$ & $\log _{10}\left(Q_{7,10}\right)_{\text {Mar-Apr }}=-2.0+1.1 \log _{10}(A)+0.1 \log _{10}($ Ordo/Miss $K+1)+0.7 \log _{10}\left(\tau_{\text {Mar-Apr }}\right)$ & 89.2 & 48.5 \\
\hline November $Q_{7,10}$ & $\log _{10}\left(Q_{7,10}\right)_{\mathrm{Nov}}=-10.2+0.7 \log _{10}(A)+5.4 \log _{10}\left(\tau_{\text {Nov-Dec }}\right)+4.0 \log _{10}\left(P_{(\text {Nov) } 61-90}\right)$ & 84.9 & 94.3 \\
\hline$* *$ December $Q_{7,10}$ & $\log _{10}\left(Q_{7,10}\right)_{\text {Dec }}=-3.1+1.1 \log _{10}(A)+0.3 \log _{10}($ Ordo/Miss $K+1)+1.2 \log _{10}\left(\tau_{\text {Annual }}\right)$ & 83.0 & 76.8 \\
\hline **January $Q_{7,10}$ & $\log _{10}\left(Q_{7,10}\right)_{\mathrm{Jan}}=-1.8+1.1 \log _{10}(A)+0.3 \log _{10}($ Ordo/Miss $K+1)$ & 90.2 & 51.3 \\
\hline$* *$ February $Q_{7,10}$ & $\log _{10}\left(Q_{7,10}\right)_{\mathrm{Feb}}=-5.1+1.2 \log _{10}(A)+0.1 \log _{10}\left(\right.$ Ordo/Miss K+1)+2.7 $\log _{10}\left(P_{(\text {Nov-Apr }) 61-90}\right)$ & 98.6 & 18.9 \\
\hline$* * \operatorname{March} Q_{7,10}$ & $\log _{10}\left(Q_{7,10}\right)_{\mathrm{Mar}}=-3.0+1.2 \log _{10}(A)+0.1 \log _{10}\left(\right.$ Ordo/Miss K+1)+2.6 $\log _{10}\left(P_{(\text {Mar }) 61-90}\right)$ & 94.8 & 33.0 \\
\hline April $Q_{7,10}$ & $\log _{10}\left(Q_{7,10}\right)_{\mathrm{Apr}}=-1.3+1.2 \log _{10}(A)$ & 91.3 & 46.7 \\
\hline \multicolumn{4}{|c|}{ Region 3} \\
\hline Annual $Q_{7,2}$ & $\log _{10}\left(Q_{7,2}\right)_{\text {Annual }}=-17.5+0.8 \log _{10}(A)+3.6 \log _{10}\left(\tau_{\text {Annual }}\right)+12.5 \log _{10}\left(P_{\text {(Mar-Apr) } 71-00}\right)$ & 68.5 & 115.5 \\
\hline Annual $Q_{7,10}$ & $\log _{10}\left(Q_{7,10}\right)_{\text {Annual }}=-29.6+1.3 \log _{10}(A)+5.0 \log _{10}\left(\tau_{\text {Annual }}\right)+21.4 \log _{10}\left(P_{\text {(Mar-Apr) } 71-00}\right)$ & 81.3 & 138.5 \\
\hline November-April $Q_{7,10}$ & $\log _{10}\left(Q_{7,10}\right)_{\text {Nov-Apr }}=-25.4+1.1 \log _{10}(A)+5.6 \log _{10}\left(\tau_{\text {Annual }}\right)+12.9 \log _{10}\left(P_{(\text {Nov-Apr }) 61-90}\right)$ & 76.9 & 99.1 \\
\hline November-December $Q_{7,10}$ & $\log _{10}\left(Q_{7,10}\right)_{\text {Nov-Dec }}=-24.7+1.1 \log _{10}(A)+5.4 \log _{10}\left(\tau_{\text {Annual }}\right)+12.5 \log _{10}\left(P_{(\text {Nov-Apr }) 61-90}\right)$ & 72.7 & 109.2 \\
\hline January-February $Q_{7,10}$ & $\log _{10}\left(Q_{7,10}\right)_{\mathrm{Jan}-\mathrm{Feb}}=-1.1+1.1 \log _{10}(A)$ & 92.1 & 48.1 \\
\hline March-April $Q_{7,10}$ & $\log _{10}\left(Q_{7,10}\right)_{\text {Mar-Apr }}=-14.2+1.2 \log _{10}(A)+12.7 \log _{10}\left(P_{(\text {Mar-Apr) } 61-90}\right)$ & 95.1 & 39.3 \\
\hline November $Q_{7,10}$ & $\log _{10}\left(Q_{7,10}\right)_{\text {Nov }}=-24.4+1.0 \log _{10}(A)+5.3 \log _{10}\left(\tau_{\text {Annual }}\right)+12.4 \log _{10}\left(P_{\text {(Nov-Apr) } 61-90}\right)$ & 70.7 & 113.4 \\
\hline$* *$ December $Q_{7,10}$ & $\log _{10}\left(Q_{7,10}\right)_{\text {Dec }}=-3.1+1.1 \log _{10}(A)+0.3 \log _{10}($ Ordo/Miss $K+1)+1.2 \log _{10}\left(\tau_{\text {Annual }}\right)$ & 83.0 & 76.8 \\
\hline
\end{tabular}


Table 7. Multiple linear weighted least squares regression models for each region in Arkansas. - Continued

[**, Insufficient data for individual equation for region; the statewide equation shown here is used for this calculation. $Q_{7}$, averaged consecutive 7-day minimum discharge; $Q_{7,10}$, 7-day, 10-year low flow; $Q_{7,2}$, 7-day, 2-year low flow; Ordo/Miss $K$, percent surficial geology as Ordovician and Mississippian rocks; $\tau_{\text {Annual }}$ tau annual in days; SoilHydro, Soil Hydrologic Group; $\tau_{\text {Nov-Dec }}$, tau, November-December (days); $P_{\text {(Nov-Apr) 71-00) }}$, precipitation 1971-2000, November-April basin average,

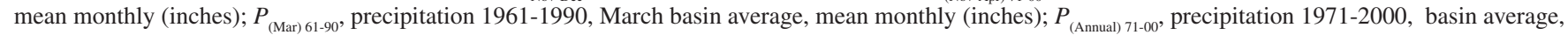
mean monthly (inches); $P_{\text {(Nov-Dec) 61-90 }}$, precipitation 1961-1990, November-December basin average, mean monthly (inches); $\tau_{\text {(Mar-April) }}$, tau, March-April (days); $P_{(\text {Nov) }}$ ${ }_{61-90}$, precipitation, 1961-1990, basin average, mean monthly (inches)]

\begin{tabular}{llcr}
\hline \multicolumn{1}{c}{ Low-flow characteristic } & \multicolumn{1}{c}{ Multiple linear weighted least squares (WLS) regression model } & $\begin{array}{c}\text { Pseudo-R } \\
\text { (percent) }\end{array}$ & $\begin{array}{c}\mathbf{S}_{\mathbf{p}} \\
\text { (percent) }\end{array}$ \\
\hline January $Q_{7,10}$ & \multicolumn{1}{c}{ Region 3-Continued } & \\
February $Q_{7,10}$ & $\log _{10}\left(Q_{7,10}\right)_{\text {Jan }}=-1.1+1.1 \log _{10}(A)$ & 89.8 & 54.6 \\
March $Q_{7,10}$ & $\log _{10}\left(Q_{7,10}\right)_{\mathrm{Feb}}=-1.0+1.1 \log _{\mathrm{10}}(A)$ & 90.7 & 52.4 \\
April $Q_{7,10}$ & $\log _{10}\left(Q_{7,10}\right)_{\mathrm{Mar}}=-0.9+1.1 \log _{10}(A)$ & 86.5 & 64.9 \\
\hline
\end{tabular}


Table 8. Continuous-streamflow and partial-record gaging stations used to form the weighted least squares regression models.

[ACR, active continuous streamflow record gaging station; ICR, inactive continuous streamflow record gaging station; PR, partial record gaging station; SACR (PR), short term active continuous recored (analyzed and listed as partial-record stations)]

\begin{tabular}{|c|c|c|c|c|c|}
\hline $\begin{array}{l}\text { Station } \\
\text { number }\end{array}$ & Station name & $\begin{array}{c}\text { Latitude } \\
\text { (degrees and } \\
\text { decimal } \\
\text { degrees) }\end{array}$ & $\begin{array}{l}\text { Longitude } \\
\text { (degrees and } \\
\text { decimal } \\
\text { degrees) }\end{array}$ & $\begin{array}{l}\text { Region } \\
\text { (plate 1) }\end{array}$ & Station type \\
\hline 07047976 & White River at Combs, Ark. & 35.8280 & 93.8320 & 1 & PR \\
\hline 07047980 & White River at Elkins, Ark. & 36.0010 & 94.0040 & 1 & PR \\
\hline 07047985 & Middle Fork White River near Fayetteville, Ark. & 36.0160 & 94.0660 & 1 & PR \\
\hline 07048000 & West Fork White River at Greenland, Ark. & 35.9830 & 94.1720 & 1 & ICR \\
\hline 07048550 & West Fork White River east of Fayetteville, Ark. & 36.0540 & 94.0830 & 1 & SACR (PR) \\
\hline 07048600 & White River near Fayetteville, Ark. & 36.0730 & 94.0810 & 1 & ACR \\
\hline 07048800 & Richland Creek at Goshen, Ark. & 36.1040 & 94.0080 & 1 & SACR (PR) \\
\hline 07048960 & War Eagle Creek near Huntsville, Ark. & 36.0420 & 93.7050 & 1 & PR \\
\hline 07049000 & War Eagle Creek near Hindsville, Ark. & 36.2000 & 93.8550 & 1 & ACR \\
\hline 07050225 & Kings River near Kingston, Ark. & 36.0880 & 93.5420 & 1 & PR \\
\hline 07050250 & Kings River near Pleasant Valley, Ark. & 36.3890 & 93.6590 & 1 & PR \\
\hline 07050390 & Osage Creek southwest of Berryville, Ark. & 36.3490 & 93.5910 & 1 & PR \\
\hline 07050500 & Kings River near Berryville, Ark. & 36.4260 & 93.6230 & 1 & ACR \\
\hline 07053207 & Long Creek at Denver, Ark. & 36.3900 & 93.3170 & 1 & SACR (PR) \\
\hline 07053250 & Yocum Creek near Oak Grove, Ark. & 36.4540 & 93.3560 & 1 & ACR \\
\hline 07054410 & Bear Creek near Omaha, Ark. & 36.4490 & 93.0750 & 1 & SACR (PR) \\
\hline 07055646 & Buffalo River near Boxley, Ark. & 35.9450 & 93.4030 & 1 & SACR (PR) \\
\hline 07055700 & Little Buffalo River near Jasper, Ark. & 36.0100 & 93.1840 & 1 & PR \\
\hline 07055875 & Richland Creek near Witts Spring, Ark. & 35.7970 & 92.9290 & 1 & ACR \\
\hline 07055893 & Calf Creek near Silverhill, Ark. & 35.9680 & 92.7760 & 1 & SACR (PR) \\
\hline 07056000 & Buffalo River near St. Joe, Ark. & 35.9830 & 92.7480 & 1 & $\mathrm{ACR}$ \\
\hline 07056510 & Bear Creek near Marshall, Ark. & 35.9410 & 92.7130 & 1 & PR \\
\hline 07057100 & Big Creek near Big Flat, Ark. & 35.9790 & 92.4810 & 1 & PR \\
\hline 07058980 & Bennetts River at Vidette, Ark. & 36.4220 & 92.1190 & 1 & SACR (PR) \\
\hline 07059450 & Big Creek near Elizabeth, Ark. & 36.3570 & 92.1130 & 1 & SACR (PR) \\
\hline 07060520 & Piney Creek near Calico Rock, Ark. & 36.1470 & 92.0710 & 1 & PR \\
\hline 07060700 & South Sylamore Creek at Allison, Ark. & 35.9360 & 92.1210 & 1 & $\mathrm{PR}$ \\
\hline 07060710 & North Sylamore Creek near Fifty Six, Ark. & 35.9950 & 92.2130 & 1 & ACR \\
\hline 07060720 & North Sylamore Creek near Allison, Ark. & 35.9680 & 92.1710 & 1 & PR \\
\hline 07060900 & Polk Bayou at Batesville, Ark. & 35.7710 & 91.6550 & 1 & PR \\
\hline 07068880 & Mud Creek near Ingram, Ark. & 36.4230 & 90.9750 & 1 & PR \\
\hline 07069265 & Myatt Creek near Salem, Ark. & 36.4440 & 91.6700 & 1 & PR \\
\hline 07069270 & South Fork Spring River near Salem, Ark. & 36.4090 & 91.8180 & 1 & PR \\
\hline 07069350 & Martins Creek near Williford, Ark. & 36.2730 & 91.3330 & 1 & PR \\
\hline 07069400 & Janes Creek at Ravenden Springs, Ark. & 36.3030 & 91.2330 & 1 & PR \\
\hline 07072900 & Strawberry River near Franklin, Ark. & 36.1780 & 91.7390 & 1 & PR \\
\hline 07073000 & Strawberry River near Evening Shade, Ark. & 36.0990 & 91.6080 & 1 & ICR \\
\hline
\end{tabular}


Table 8. Continuous-streamflow and partial-record gaging stations used to form the weighted least squares regression models.-Continued

[ACR, active continuous streamflow record gaging station; ICR, inactive continuous streamflow record gaging station; PR, partial record gaging station; SACR (PR), short term active continuous recored (analyzed and listed as partial-record stations)]

\begin{tabular}{|c|c|c|c|c|c|}
\hline $\begin{array}{l}\text { Station } \\
\text { number }\end{array}$ & Station name & $\begin{array}{c}\text { Latitude } \\
\text { (degrees and } \\
\text { decimal } \\
\text { degrees) }\end{array}$ & $\begin{array}{c}\text { Longitude } \\
\text { (degrees and } \\
\text { decimal } \\
\text { degrees) }\end{array}$ & $\begin{array}{l}\text { Region } \\
\text { (plate 1) }\end{array}$ & Station type \\
\hline 07073500 & Piney Fork at Evening Shade, Ark. & 36.0810 & 91.6110 & 1 & ICR \\
\hline 07073600 & Mill Creek at Evening Shade, Ark. & 36.0660 & 91.6100 & 1 & PR \\
\hline 07073995 & North Big Creek near Evening Shade, Ark. & 36.1380 & 91.5030 & 1 & $\mathrm{PR}$ \\
\hline 07074000 & Strawberry River near Poughkeepsie, Ark. & 36.1100 & 91.4500 & 1 & ICR \\
\hline 07074248 & South Big Creek near Strawberry, Ark. & 36.0200 & 91.3360 & 1 & PR \\
\hline 07074250 & Reeds Creek near Strawberry, Ark. & 35.9830 & 91.3370 & 1 & PR \\
\hline 07074260 & Cooper Creek near Smithville, Ark. & 36.0530 & 91.3100 & 1 & PR \\
\hline 07074400 & Curia Creek near Dowdy, Ark. & 35.8710 & 91.3100 & 1 & PR \\
\hline 07074450 & Dota Creek near Newark, Ark. & 35.7290 & 91.4140 & 1 & PR \\
\hline 07075200 & Devils Fork Little Red river near Brownsville, Ark. & 35.6390 & 92.0320 & 2 & PR \\
\hline 07075300 & South Fork of Little Red River at Clinton, Ark. & 35.5870 & 92.4520 & 2 & ACR \\
\hline 07075390 & Archey Creek at Clinton, Ark. & 35.6040 & 92.4600 & 2 & $\mathrm{PR}$ \\
\hline 07075500 & South Fork Little Red River near Clinton, Ark. & 35.5670 & 92.3830 & 2 & ICR \\
\hline 07076510 & Big Creek near Pangburn, Ark. & 35.4560 & 91.8450 & 2 & PR \\
\hline 07076530 & Big Creek near Letona, Ark. & 35.3620 & 91.8010 & 2 & PR \\
\hline 07076800 & Bayou Des Arc near Garner, Ark. & 35.1720 & 91.7460 & 2 & PR \\
\hline 07076850 & Cypress Bayou near Beebe, Ark. & 35.0250 & 91.8730 & 2 & ICR \\
\hline 07194790 & Muddy Fork Illinois River near Savoy, Ark. & 36.0700 & 94.3480 & 1 & PR \\
\hline 07194800 & Illinois River at Savoy, Ark. & 36.1030 & 94.3440 & 1 & ACR \\
\hline 07194950 & Little Osage Creek near Healing Springs, Ark. & 36.2330 & 94.2770 & 1 & PR \\
\hline 07195400 & Illinois River at Hwy 16 near Siloam Springs, Ark. & 36.1450 & 94.4940 & 1 & SACR (PR) \\
\hline 07195430 & Illinois River South of Siloam Springs, Ark. & 36.1090 & 94.5340 & 1 & ACR \\
\hline 07195800 & Flint Creek at Springtown, Ark. & 36.2550 & 94.4340 & 1 & ACR \\
\hline 07196900 & Baron Fork at Dutch Mills, Ark. & 35.8800 & 94.4860 & 1 & ACR \\
\hline 07196950 & Evansville Creek at Evansville, Ark. & 35.8060 & 94.4960 & 1 & PR \\
\hline 07246970 & Jones Creek near Waldron, Ark. & 34.8870 & 94.1880 & 2 & PR \\
\hline 07247000 & Poteau River at Cauthron, Ark. & 34.9190 & 94.2990 & 2 & ACR \\
\hline 07247010 & Poteau River near Bates, Ark. & 34.8890 & 94.4200 & 2 & $\mathrm{PR}$ \\
\hline 07247100 & Black Fork near Page, Okla. & 34.7600 & 94.4900 & 2 & PR \\
\hline 07247200 & Big Creek at Howard, Ark. & 34.7070 & 94.4370 & 2 & PR \\
\hline 07247300 & Haws Creek near Black Fork, Ark. & 34.7930 & 94.4160 & 2 & PR \\
\hline 07249400 & James Fork near Hackett, Ark. & 35.1630 & 94.4070 & 2 & ACR \\
\hline 07249500 & Cove Creek near Lee Creek, Ark. & 35.7220 & 94.4080 & 2 & ICR \\
\hline 07249600 & Lee Creek at Natural Dam, Ark. & 35.6460 & 94.3940 & 2 & PR \\
\hline 07249700 & Mountain Fork Creek at Natural Dam, Ark. & 35.6450 & 94.3970 & 2 & PR \\
\hline 07249800 & Lee Creek at Short, Okla. & 35.5660 & 94.5320 & 2 & SACR (PR) \\
\hline 07249985 & Lee Creek near Short, Okla. & 35.5190 & 94.4660 & 2 & ACR \\
\hline
\end{tabular}


Table 8. Continuous-streamflow and partial-record gaging stations used to form the weighted least squares regression models.-Continued

[ACR, active continuous streamflow record gaging station; ICR, inactive continuous streamflow record gaging station; PR, partial record gaging station; SACR (PR), short term active continuous recored (analyzed and listed as partial-record stations)]

\begin{tabular}{|c|c|c|c|c|c|}
\hline $\begin{array}{l}\text { Station } \\
\text { number }\end{array}$ & Station name & $\begin{array}{c}\text { Latitude } \\
\text { (degrees and } \\
\text { decimal } \\
\text { degrees) }\end{array}$ & $\begin{array}{c}\text { Longitude } \\
\text { (degrees and } \\
\text { decimal } \\
\text { degrees) }\end{array}$ & $\begin{array}{l}\text { Region } \\
\text { (plate 1) }\end{array}$ & Station type \\
\hline 07250600 & Vache Grasse Creek near Lavaca, Ark. & 35.3180 & 94.2150 & 2 & PR \\
\hline 07250935 & Jones Creek at Winfrey, Ark. & 35.7360 & 94.1030 & 2 & SACR (PR) \\
\hline 07250965 & Frog Bayou near Winfrey, Ark. & 35.7270 & 94.1070 & 2 & SACR (PR) \\
\hline 07250974 & Jack Creek near Winfrey, Ark. & 35.7050 & 94.0890 & 2 & SACR (PR) \\
\hline 07251400 & Cedar Creek near Rudy, Ark. & 35.5290 & 94.2780 & 2 & PR \\
\hline 07251800 & Little Mulberry Creek near Oark, Ark. & 35.6860 & 93.6600 & 2 & PR \\
\hline 07251900 & Mulberry River near Cass, Ark. & 35.6690 & 93.8290 & 2 & PR \\
\hline 07252000 & Mulberry River near Mulberry. Ark. & 35.5770 & 94.0160 & 2 & ACR \\
\hline 07252100 & Little Mulberry Creek near Mulberry, Ark. & 35.5100 & 94.0710 & 2 & PR \\
\hline 07252300 & White Oak Creek near Ozark, Ark. & 35.5070 & 93.9460 & 2 & PR \\
\hline 07256200 & Horsehead Creek at Hartman, Ark. & 35.4350 & 93.6060 & 2 & PR \\
\hline 07256700 & Big Shoal Creek near New Blaine, Ark. & 35.2920 & 93.4600 & 2 & PR \\
\hline 07257006 & Big Piney Creek at Highway 164 near Dover, Ark. & 35.5060 & 93.1810 & 2 & ACR \\
\hline 07257470 & Middle Fork Illinois Bayou near Hector, Ark. & 35.5280 & 92.9410 & 2 & $\mathrm{PR}$ \\
\hline 07257480 & North Fork Illinois Bayou near Scottsville, Ark. & 35.5000 & 93.0190 & 2 & PR \\
\hline 07257500 & Illinois Bayou near Scottsville, Ark. & 35.4660 & 93.0410 & 2 & ACR \\
\hline 07258500 & Petit Jean River near Booneville, Ark. & 35.1070 & 93.9240 & 2 & ACR \\
\hline 07258700 & Sugar Creek near Sugar Grove, Ark. & 35.0770 & 93.8190 & 2 & PR \\
\hline 07260000 & Dutch Creek at Waltreak, Ark. & 34.8870 & 93.6130 & 2 & ACR \\
\hline 07260500 & Petit Jean River at Danville, Ark. & 35.0590 & 93.3960 & 2 & $\mathrm{ACR}$ \\
\hline 07260673 & $\begin{array}{l}\text { West Fork Point Remove Creek near } \\
\text { Hattieville, Ark. }\end{array}$ & 35.3250 & 92.8730 & 2 & SACR (PR) \\
\hline 07260700 & Point Rmove Creek near Morrilton, Ark. & 35.1820 & 92.7840 & 2 & PR \\
\hline 07261000 & Cadron Creek near Guy, Ark. & 35.2990 & 92.4040 & 2 & ACR \\
\hline 07261200 & East Fork Cadron Creek near Enola, Ark. & 35.2180 & 92.2790 & 2 & PR \\
\hline 07261400 & Mill Creek near Boles, Ark. & 34.7370 & 94.0800 & 2 & PR \\
\hline 07261500 & Fourche LaFave River near Gravelly, Ark. & 34.8730 & 93.6570 & 2 & ACR \\
\hline 07261600 & Gafford Creek near Bluffton, Ark. & 34.8980 & 93.6120 & 2 & PR \\
\hline 07263000 & South Fourche LaFave River near Hollis, Ark. & 34.9110 & 93.0560 & 2 & ICR \\
\hline 07263295 & Maumelle River at Williams Junction, Ark. & 34.8760 & 92.7740 & 2 & ACR \\
\hline 07336900 & Walnut Bayou near Foreman, Ark. & 33.6540 & 94.3590 & 2 & PR \\
\hline 07338700 & Twomile Creek near Hatfield, Ark. & 34.5140 & 94.3370 & 3 & PR \\
\hline 07338720 & Mountain Fork near Hatfield, Ark. & 34.5050 & 94.4310 & 3 & PR \\
\hline 07339200 & Rolling Fork near Grannis, Ark. & 34.2470 & 94.3730 & 3 & PR \\
\hline 07339500 & Rolling Fork near DeQueen, Ark. & 34.0470 & 94.4130 & 3 & ICR \\
\hline 07340300 & Cossatot River near Vandervoort, Ark. & 34.3790 & 94.2360 & 3 & ACR \\
\hline 07340400 & Cossatot River near Umpire, Ark. & 34.2960 & 94.1770 & 3 & PR \\
\hline
\end{tabular}


Table 8. Continuous-streamflow and partial-record gaging stations used to form the weighted least squares regression models.-Continued

[ACR, active continuous streamflow record gaging station; ICR, inactive continuous streamflow record gaging station; PR, partial record gaging station; SACR (PR), short term active continuous recored (analyzed and listed as partial-record stations)]

\begin{tabular}{|c|c|c|c|c|c|}
\hline $\begin{array}{l}\text { Station } \\
\text { number }\end{array}$ & Station name & $\begin{array}{c}\text { Latitude } \\
\text { (degrees and } \\
\text { decimal } \\
\text { degrees) }\end{array}$ & $\begin{array}{c}\text { Longitude } \\
\text { (degrees and } \\
\text { decimal } \\
\text { degrees) }\end{array}$ & $\begin{array}{l}\text { Region } \\
\text { (plate 1) }\end{array}$ & Station type \\
\hline 07341000 & Saline River near Dierks, Ark. & 34.0960 & 94.0840 & 3 & ICR \\
\hline 07341200 & Saline River near Lockesburg, Ark. & 33.9623 & 94.0616 & 3 & ICR \\
\hline 07349430 & Bodcau Creek at Stamps, Ark. & 33.3670 & 93.5220 & 2 & ICR \\
\hline 07355810 & Ouachita River near Mena, Ark. & 34.5840 & 94.1520 & 3 & PR \\
\hline 07356000 & Ouachita River near Mount Ida, Ark. & 34.6100 & 93.6970 & 3 & ACR \\
\hline 07356500 & South Fork Ouachita River at Mount Ida, Ark. & 34.5600 & 93.6360 & 3 & ICR \\
\hline 07357710 & Glazypeau Creek at Mountain Pine, Ark. & 34.5720 & 93.1590 & 3 & PR \\
\hline 07358010 & Fourche A Loupe Creek near Hot Springs, Ark. & 34.3830 & 93.1330 & 3 & PR \\
\hline 07358700 & Gulpha Creek near Hot Springs, Ark. & 34.4710 & 92.9860 & 3 & PR \\
\hline 07359610 & Caddo River near Caddo Gap, Ark. & 34.3830 & 93.6060 & 3 & ACR \\
\hline 07359800 & Caddo River near Alpine, Ark. & 34.2670 & 93.3620 & 3 & ICR \\
\hline 07360200 & Little Missouri River near Langley, Ark. & 34.3110 & 93.8990 & 3 & SACR (PR) \\
\hline 07361000 & Little Missouri River near Murfreesboro, Ark. & 34.0490 & 93.7200 & 3 & ICR \\
\hline 07361025 & Prairie Creek near Murfreesboro, Ark. & 34.0430 & 93.6840 & 3 & PR \\
\hline 07361160 & North Fork Ozan Creek near McCaskill, Ark. & 33.8730 & 93.6420 & 3 & PR \\
\hline 07361500 & Antoine River at Antoine, Ark. & 34.0390 & 93.4180 & 3 & ACR \\
\hline 07361540 & Wolf Creek near Antoine, Ark. & 34.0200 & 93.4380 & 3 & PR \\
\hline 07361640 & Little Terre Rouge Creek near Emmet, Ark. & 33.7490 & 93.4630 & 3 & PR \\
\hline 07361650 & Terre Rouge Creek near Prescott, Ark. & 33.7790 & 93.2360 & 3 & PR \\
\hline 07361800 & Terre Noire Creek near Gurdon, Ark. & 33.9170 & 93.0360 & 3 & PR \\
\hline 07362090 & Camp Creek near Smackover, Ark. & 33.3530 & 92.7740 & 2 & PR \\
\hline 07362100 & Smackover Creek near Smackover, Ark. & 33.3760 & 92.7770 & 2 & ACR \\
\hline 07362500 & Moro Creek near Fordyce, Ark. & 33.7920 & 92.3330 & 2 & ACR \\
\hline 07362550 & Moro Creek near Banks, Ark. & 33.5440 & 92.3170 & 2 & $\mathrm{PR}$ \\
\hline 07362587 & Alum Fork Saline River near Reform, Ark. & 34.7970 & 92.9330 & 3 & ACR \\
\hline 07362600 & Alum Fork Saline River at Crows, Ark. & 34.6160 & 92.7490 & 3 & PR \\
\hline 07362700 & Middle Fork Saline River at Crows, Ark. & 34.6150 & 92.7790 & 3 & PR \\
\hline 07362800 & South Fork Saline River near Hot Springs, Ark. & 34.5860 & 92.9700 & 3 & PR \\
\hline 07362900 & North Fork Saline River near Benton, Ark. & 34.6050 & 92.6190 & 3 & PR \\
\hline 07363110 & Big Creek at Poyen, Ark. & 34.3140 & 92.6400 & 3 & PR \\
\hline 07363160 & Saline River near Leola, Ark. & 34.2100 & 92.5480 & 3 & PR \\
\hline 07363180 & Lost Creek near Sheridan, Ark. & 34.3140 & 92.4660 & 2 & PR \\
\hline 07363276 & Hurricane Creek near Ico, Ark. & 34.4510 & 92.3720 & 2 & PR \\
\hline 07364060 & Bayou Lapile at Strong, Ark. & 33.1150 & 92.3460 & 2 & PR \\
\hline 07365800 & Cornie Bayou near Three Creeks, Ark. & 33.0390 & 92.9380 & 2 & ICR \\
\hline 07365900 & Three Creeks near Three Creeks, Ark. & 33.0670 & 92.8840 & 2 & ICR \\
\hline
\end{tabular}


Table 9. Logistic regression models: Basin attribute ranges.

$\left[A\left(\mathrm{mi}^{2}\right)\right.$, area in square miles; $\tau_{\text {Annual }}$ (days), tau annual in days; Ordo/Miss $K$, percent surficial geology as Ordovician and Mississippian rocks; **, Insufficient annual events equal to zero cubic feet per second for individual equation; the statewide equation is used for this calculation; --, attribute not used in regression model]

\begin{tabular}{|c|c|c|c|c|c|c|}
\hline \multirow{2}{*}{ Low-flow characteristic } & \multicolumn{2}{|c|}{$A\left(m i^{2}\right)$} & \multicolumn{2}{|c|}{$\tau_{\text {Annual }}$ (days) } & \multicolumn{2}{|c|}{ Ordo/Miss $K+1$ (percent) } \\
\hline & $\begin{array}{l}\text { Mini- } \\
\text { mum }\end{array}$ & $\begin{array}{c}\text { Maxi- } \\
\text { mum }\end{array}$ & $\begin{array}{l}\text { Min- } \\
\text { mum }\end{array}$ & $\begin{array}{c}\text { Maxi- } \\
\text { mum }\end{array}$ & $\begin{array}{l}\text { Mini- } \\
\text { mum }\end{array}$ & $\begin{array}{c}\text { Maxi- } \\
\text { mum }\end{array}$ \\
\hline \multicolumn{7}{|c|}{ Region 1} \\
\hline Annual $Q_{7}$ & 3.1 & 828.5 & 8.7 & 40.9 & -- & -- \\
\hline$* *$ November-April $Q_{7}$ & 3.1 & 931.9 & 5.3 & 40.9 & 1.0 & 101.0 \\
\hline$* *$ November-December $Q_{7}$ & 3.1 & 931.9 & 5.3 & 40.9 & 1.0 & 101.0 \\
\hline$* *$ November $Q_{7}$ & 3.1 & 931.9 & 5.3 & 40.9 & 1.0 & 101.0 \\
\hline \multicolumn{7}{|c|}{ Region 2} \\
\hline Annual $Q_{7}$ & -- & -- & 5.3 & 10.0 & -- & -- \\
\hline$* *$ November-April $Q_{7}$ & 3.3 & 763.0 & 5.3 & 10.0 & -- & -- \\
\hline$* *$ November-December $Q_{7}$ & 3.3 & 763.0 & 5.3 & 10.0 & -- & -- \\
\hline$* *$ November $Q_{7}$ & 3.3 & 763.0 & 5.3 & 10.0 & -- & -- \\
\hline \multicolumn{7}{|c|}{ Region 3} \\
\hline Annual $Q_{7}$ & -- & -- & 6.2 & 12.1 & 3.7 & 101.0 \\
\hline$* *$ November-April $Q_{7}$ & 3.1 & 931.9 & 5.3 & 40.9 & 1.0 & 101.0 \\
\hline$* *$ November-December $Q_{7}$ & 3.1 & 931.9 & 5.3 & 40.9 & 1.0 & 101.0 \\
\hline$* *$ November $Q_{7}$ & 3.1 & 931.9 & 5.3 & 40.9 & 1.0 & 101.0 \\
\hline
\end{tabular}


Table 10. Weighted least squares regression models: Basin attribute ranges.

[A ( $\mathrm{mi}^{2}$ ), area in square miles; Ordo/Miss K, percent surficial geology as Ordovician and Mississippian rocks; Soil hydro, soil hydrologic group; $\tau$, tau in day: Min, minimum; Max, maximum; **, Insufficient data for individual equation for this region; the statewide equation is used for this calculation. --, attribute not used in regression model]

\begin{tabular}{|c|c|c|c|c|c|c|c|c|c|c|}
\hline \multirow[b]{2}{*}{ Low-flow characteristic } & \multicolumn{2}{|c|}{$A\left(\mathrm{mi}^{2}\right)$} & \multicolumn{2}{|c|}{$\begin{array}{c}\text { Ordo/Miss } \\
\text { K+1 (percent) }\end{array}$} & \multicolumn{2}{|c|}{ Soil hydro } & \multicolumn{2}{|c|}{$\begin{array}{l}\text { Precipitation } \\
\text { (inches) }\end{array}$} & \multicolumn{2}{|c|}{$\tau$ (days) } \\
\hline & Min & Max & Min & Max & Min & Max & Min & Max & Min & Max \\
\hline \multicolumn{11}{|c|}{ Region 1} \\
\hline Annual $Q_{7,2}$ & 12.1 & 828.5 & 1.5 & 101 & 2.5 & 2.7 & -- & -- & -- & -- \\
\hline Annual $Q_{7,10}$ & 12.1 & 828.5 & 1.5 & 101 & 2.5 & 2.7 & -- & -- & -- & -- \\
\hline November-April $Q_{7,10}$ & 12.1 & 828.5 & 1 & 101 & -- & -- & -- & -- & -- & -- \\
\hline November-December $Q_{7,10}$ & 12.1 & 828.5 & 1 & 101 & -- & -- & -- & -- & -- & -- \\
\hline January-February $Q_{7,10}$ & 12.1 & 828.5 & 1 & 101 & -- & -- & -- & -- & -- & -- \\
\hline March-April $\hat{Q}_{7,10}$ & 12.1 & 828.5 & 1 & 101 & -- & -- & $21.3^{1}$ & $26.2^{1}$ & -- & -- \\
\hline November $Q_{7,10}$ & 12.1 & 828.5 & 1 & 101 & -- & -- & -- & -- & -- & -- \\
\hline December $Q_{7,10}$ & 12.1 & 828.5 & 1 & 101 & -- & -- & -- & -- & -- & -- \\
\hline January $Q_{7,10}$ & 12.1 & 828.5 & 1 & 101 & -- & -- & -- & -- & -- & -- \\
\hline February $Q_{7,10}$ & 12.1 & 828.5 & 1 & 101 & -- & -- & $21.3^{1}$ & $26.2^{1}$ & -- & -- \\
\hline $\operatorname{March} Q_{7,10}$ & 12.1 & 828.5 & -- & -- & -- & -- & $4.1^{2}$ & $5.3^{2}$ & -- & -- \\
\hline April $Q_{7,10}$ & 12.1 & 828.5 & -- & -- & -- & -- & $21.3^{1}$ & $26.2^{1}$ & -- & -- \\
\hline \multicolumn{11}{|c|}{ Region 2} \\
\hline Annual $Q_{7,2}$ & 8.0 & 763.0 & -- & -- & -- & -- & -- & -- & $6.2^{3}$ & $9.9^{3}$ \\
\hline Annual $Q_{7,10}$ & 4.7 & 931.9 & -- & -- & -- & -- & $44.5^{4}$ & $61.9^{4}$ & $6.6^{3}$ & $26.7^{3}$ \\
\hline November-April $Q_{7,10}$ & 8.0 & 763.0 & -- & -- & -- & -- & $7.6^{5}$ & $10.9^{5}$ & -- & -- \\
\hline November-December $Q_{7,10}$ & 8.0 & 488.7 & -- & -- & -- & -- & $7.6^{5}$ & $10.9^{5}$ & -- & -- \\
\hline$* *$ January-February $Q_{7,10}$ & 4.7 & 931.9 & 1 & 101 & -- & -- & $8.3^{6}$ & $12.7^{6}$ & -- & -- \\
\hline$* *$ March-April $Q_{7,10}$ & 4.7 & 931.9 & 1 & 101 & -- & -- & -- & -- & $4.5^{7}$ & $25.2^{7}$ \\
\hline November $Q_{7,10}$ & 8.0 & 763.0 & -- & -- & -- & -- & $4.3^{8}$ & $5.6^{8}$ & $6.5^{9}$ & $12.33^{9}$ \\
\hline$* *$ December $Q_{7,10}$ & 4.7 & 931.9 & 1 & 101 & -- & -- & -- & -- & $5.5^{3}$ & $26.7^{3}$ \\
\hline$* *$ January $Q_{7,10}$ & 4.7 & 931.9 & 1 & 101 & -- & -- & -- & -- & -- & -- \\
\hline
\end{tabular}


Table 10. Weighted least squares regression models: Basin attribute ranges. - Continued

[A $\left(\mathrm{mi}^{2}\right)$, area in square miles; Ordo/Miss K, percent surficial geology as Ordovician and Mississippian rocks; Soil hydro, soil hydrologic group; $\tau$, tau in day: Min, minimum; Max, maximum; **, Insufficient data for individual equation for this region; the statewide equation is used for this calculation. --, attribute not used in regression model]

\begin{tabular}{|c|c|c|c|c|c|c|c|c|c|c|}
\hline \multirow[b]{2}{*}{ Low-flow characteristic } & \multicolumn{2}{|c|}{$A\left(\mathrm{mi}^{2}\right)$} & \multicolumn{2}{|c|}{$\begin{array}{c}\text { Ordo/Miss } \\
\mathrm{K}+1 \text { (percent) }\end{array}$} & \multicolumn{2}{|c|}{ Soil hydro } & \multicolumn{2}{|c|}{$\begin{array}{c}\text { Precipitation } \\
\text { (inches) }\end{array}$} & \multicolumn{2}{|c|}{$\tau$ (days) } \\
\hline & Min & Max & Min & Max & Min & Max & Min & Max & Min & Max \\
\hline \multicolumn{11}{|c|}{ Region 2-Continued } \\
\hline$* *$ February $Q_{7,10}$ & 4.7 & 931.9 & 1 & 101 & -- & -- & $19.8^{6}$ & $31.1^{6}$ & -- & -- \\
\hline$* * \operatorname{March} Q_{7,10}$ & 4.7 & 931.9 & 1 & 101 & -- & -- & $4.1^{10}$ & $6.6^{10}$ & -- & -- \\
\hline$* *$ April $Q_{7,10}$ & 6.9 & 763.0 & -- & -- & -- & -- & -- & -- & -- & -- \\
\hline \multicolumn{11}{|c|}{ Region 3} \\
\hline Annual $Q_{7,2}$ & 4.7 & 931.9 & -- & -- & -- & -- & $10.0^{11}$ & $12.3^{11}$ & $6.6^{3}$ & $12.1^{3}$ \\
\hline Annual $Q_{7,10}$ & 4.7 & 931.9 & -- & -- & -- & -- & $10.0^{11}$ & $12.3^{11}$ & $6.6^{3}$ & $12.1^{3}$ \\
\hline November-April $Q_{7,10}$ & 4.7 & 931.9 & -- & -- & -- & -- & $25.8^{6}$ & $30.7^{6}$ & $6.2^{3}$ & $12.1^{3}$ \\
\hline November-December $Q_{7,10}$ & 4.7 & 931.9 & -- & -- & -- & -- & $25.8^{6}$ & $30.7^{6}$ & $6.2^{9}$ & $12.1^{9}$ \\
\hline January-February $Q_{7,10}$ & 4.7 & 931.9 & -- & -- & -- & -- & -- & -- & -- & -- \\
\hline March-April $\hat{Q}_{7,10}$ & 4.7 & 931.9 & -- & -- & -- & -- & $10.0^{12}$ & $11.6^{12}$ & -- & -- \\
\hline November $Q_{7,10}$ & 4.7 & 931.9 & -- & -- & -- & -- & $25.8^{6}$ & $30.7^{6}$ & $6.2^{3}$ & $12.1^{3}$ \\
\hline December $Q_{7,10}$ & 4.7 & 931.9 & -- & -- & -- & -- & $27.9^{1}$ & $32.8^{1}$ & $6.2^{3}$ & $12.1^{3}$ \\
\hline January $Q_{7,10}$ & 4,7 & 931.9 & -- & -- & -- & -- & -- & -- & -- & -- \\
\hline February $Q_{7,10}$ & 4.7 & 931.9 & -- & -- & -- & -- & -- & -- & -- & -- \\
\hline $\operatorname{March} Q_{7,10}$ & 4,7 & 931.9 & -- & -- & -- & -- & -- & -- & -- & -- \\
\hline April $Q_{7,10}$ & 4.7 & 931.9 & -- & -- & -- & -- & -- & -- & -- & -- \\
\hline
\end{tabular}

${ }^{1}$ Precipitation 1971-2000, November-April basin average, Mean seasonal (inches).

${ }^{2}$ Precipitation 1961-1990, March basin average, Mean monthly (inches).

${ }^{3}$ Tau annual, days.

${ }^{4}$ Precipitation 1971-2000, basin average, Mean annual (inches).

${ }^{5}$ Precipitation 1961-1990, November-December basin average, Mean seasonal (inches).

${ }^{6}$ Precipitation 1961-1990, November-April basin average, Mean seasonal (inches).

${ }^{7}$ Tau, March-April (days).

${ }^{8}$ Precipitation 1961-1990, November basin average, Mean monthly (inches).

${ }^{9}$ Tau, November-December (days).

${ }^{10}$ Precipitation 1961-1990, March basin average, Mean monthly (inches).

${ }^{11}$ Precipitation, 1971-2000, March-April basin average, Mean seasonal (inches).

${ }^{12}$ Precipitation 1961-1990, March-April basin average, Mean seasonal (inches). 
Suppose estimates of the annual $Q_{7,10}(T=10)$ value within an ungaged basin in Region 1 with $A=20 \mathrm{mi}^{2}, \tau_{\text {annual }}$ $=12$ days, Ordo/Miss $K=20$ percent, and $S l_{\text {HydroGroup }}=2.6$ is desired. If the basin attributes fall within the appropriate ranges (tables 9-10) then the logistic and conventional WLS regression model can be applied to this basin. The first step is to determine the probability that the annual $Q_{7}$ flow is zero using the Region 1 logistic regression model for annual $Q_{7}$ (table 6).

$$
\begin{aligned}
& p_{\text {zero }}=1-\left(\frac{e^{\hat{\beta}_{0}+\hat{\beta}_{A} \log _{10}(A)+\hat{\beta}_{\text {zammal }} \log _{10}\left(\tau_{\text {ammal }}\right)}}{1+e^{\hat{\beta}_{0}+\hat{\beta}_{A} \log _{10}(A)+\hat{\beta}_{\text {zammal }} \log _{10}\left(\tau_{\text {ammal }}\right)}}\right) \Rightarrow \\
& p_{\text {zero }}=1-\left(\frac{e^{-20+3.0 \log _{10}(20)+16.8 \log _{10}(12)}}{1+e^{-20+3.0 \log _{10}(20)+16.8 \log _{10}(12)}}\right) \Rightarrow \\
& p_{\text {zero }}=1-\left(\frac{7.6}{1+7.6}\right) \Rightarrow p_{\text {zero }}=0.12 .
\end{aligned}
$$

To determine whether the annual $Q_{7,10}$ for an ungaged basin is zero, the non-exceedence probability $(=1 / T=1 / 10=0.1)$ is compared to $p_{\text {zero }}(=0.12)$. In this case, $p_{\text {zero }}$ is greater than 0.1 , so the annual $Q_{7,10}$ is estimated to be zero for this example.

Using the previous example, but with $A=100 \mathrm{mi}^{2}$ (instead of $20 \mathrm{mi}^{2}$ ) the user wishes to calculate the annual $Q_{7,10}$. Computing the probability that the annual $Q_{7}$ flow is zero using the Region 1 logistic regression model for $Q_{7}$ (table 6):

$$
\begin{aligned}
& p_{\text {zero }}=1-\left(\frac{e^{\hat{\beta}_{0}+\hat{\beta}_{A} \log _{10}(A)+\hat{\beta}_{\text {zannual }} \log _{10}\left(\tau_{\text {anmual }}\right)}}{1+e^{\hat{\beta}_{0}+\hat{\beta}_{A} \log _{10}(A)+\hat{\beta}_{\text {tanual }} \log _{10}\left(\tau_{\text {arnual }}\right)}}\right) \Rightarrow \\
& p_{\text {zero }}=1-\left(\frac{e^{-20+3.0 \log _{10}(100)+16.8 \log _{10}(12)}}{1+e^{-20+3.0 \log _{10}(100)+16.8 \log _{10}(12)}}\right) \Rightarrow \\
& p_{\text {zero }}=1-\left(\frac{62.2}{1+62.2}\right) \Rightarrow p_{\text {zero }}=0.02 .
\end{aligned}
$$

Again the non-exceedence probability $(=1 / T=1 / 10=0.1)$ is compared to $p_{\text {zero }}(=0.02)$. In this case, $p_{\text {zero }}$ is less than 0.1 , so the annual $Q_{7,10}$ is estimated by the WLS regression model for Region 1. From table 7,

$$
\begin{aligned}
& \log _{10}\left(Q_{7,10}\right)=6.9+0.9 \log _{10}(A)-26.7 \log _{10} \\
& (\text { SoilHydro })+1.3 \log _{10}(\text { Ordo } / \text { Miss } K+1) \Rightarrow \\
& \log _{10}\left(Q_{7,10}\right)=6.9+0.9 \log _{10}(100)- \\
& 26.7 \log _{10}(2.6)+1.3 \log _{10}(20+1) \Rightarrow Q_{7,10}=0.22 \mathrm{ft}^{3} / \mathrm{s}
\end{aligned}
$$

\section{Use of Computer Program}

A computer program, LFArk1.exe program, is on the compact disk included with this report. The example calculations in the "Use of Regression Models" section are automated in the program. A user's manual is included in the Lowflow_Program_Instructions file. Instructions for installing the program on a Windows-based computer are included in the user's manual. The program facilitates data entry to apply the logistic and WLS regression models.

\section{Summary}

The low-flow characteristics of a stream ultimately affect its utilization by humans. Specific information on the lowflow characteristics of streams is essential to State watermanagement agencies such as the Arkansas Department of Environmental Quality (ADEQ), Arkansas Natural Resources Commission (ANRC), and Arkansas Game and Fish Commission (AGFC) when dealing with problems related to irrigation, municipal and industrial water supplies, fish and wildlife conservation, and dilution of waste. Low-flow frequency data are of particular value to management agencies responsible for the development and management of the State's water resources.

Historically, limits imposed by National Pollutant Discharge Elimination System permits issued by the ADEQ for wastewater discharge into streams have been based upon the annual 7-day, 10-year low flow $\left(Q_{7,10}\right)$ at the location of wastewater discharge. In 2005, the ADEQ acquired approval from the U.S. Environmental Protection Agency (USEPA) to issue NPDES permits with limits for ammonia toxicity based upon a monthly $Q_{7,10}$ during the months of November through April. This approval allows regulatory agencies, such as the ADEQ, to better manage the available water resources by allowing an increase of wastewater discharge into streams during periods of higher flows that do not occur in the period of July through October in Arkansas.

This report contains the low-flow characteristics for 70 active continuous-streamflow record gaging stations, 59 inactive continuous-streamflow record stations, and 101 partialrecord gaging stations. These characteristics are estimates of the $\left(Q_{7,10}\right)$ and the annual 7-day, 2-year low flow $\left(Q_{7,2}\right)$, and the seasonal, bimonthly, and monthly $\left(Q_{7,10}\right)$ for the 129 active and inactive continuous-streamflow record and 101 partialrecord gaging stations.

Low-flow characteristics were computed on the basis of streamflow data for the period of record for discontinued continuous-streamflow record gaging stations and through September 2005 for active continuous-streamflow record and partial-record streamflow gaging stations. The low-flow characteristics of these continuous- and partial-record streamflow gaging stations were utilized in a regional regression analysis to produce equations for estimating the annual, seasonal, bimonthly, and monthly (November through April) $\left(Q_{7,10}\right)$ 's 
and the annual $\left(Q_{7,2}\right)$ for ungaged streams in the western twothirds of Arkansas.

\section{Selected References}

Aitchison, J., and Brown, J.A.C., 1957, The lognormal distribution: New York, Cambridge University Press, 176 p.

Arkansas Soil and Water Conservation Commission, 1981, Lakes of Arkansas, Arkansas State water plan, 157 p.

Bent, G.C., and Steeves, P.A., 2006, A revised logistic regression equation and an automated procedure for mapping the probability of a stream flowing perennially in Massachusetts: U.S. Geological Survey Scientific Investigations Report 2006-5031, 107 p.

Boussinesq, J., 1903, Sur le débit, en temps de sécheresse, d'une source allimentée par une nappe d'eaux d'infiltration: C. R. Acad. Sci., 136, p. 1511-1517.

Brigham Young University, 2005, WMS Watershed modeling system-Users manual-Version 7.1: Provo, Utah, Environmental Modeling Research Laboratory [variously paged].

Brutsaert, W., 1982, Evaporation into the atmosphere: Dordrecht, The Netherlands, Kluwer Academic Publishers, 299 p.

Brutsaert, W., 2005, Hydrology an introduction: Cambridge, United Kingdom, Cambridge University Press, 605 p.

Brutsaert, W., and Lopez, J.P., 1998, Basin-scale geohydrologic drought flow features of riparian aquifers in the southern Great Plains: Water Resources Research., v. 34, no. 2, p. 233-240.

Brutsaert, W., and Nieber, J.L., 1977, Regionalized drought flow hydrographs from a mature glaciated plateau: Water Resources Research., v. 13, no. 3, p. 637-643.

Eng, K., and Brutsaert, W., 1999, Generality of drought flow characteristics within the Arkansas River Basin: Journal Geophysical Research, v. 104, no. D16, p. 19435-19441.

Eng, K. and Milly, P. C. D., 2007, Relating low-flow characteristics to the base flow recession time constant at partial record stream gauges: Water Resources Research, v. 43, W01201, doi:10.1029/2006WR005293.

Fenneman, N.M., and Johnson, D.W., 1946, Physical divisions of the United States (Map): Washington, D.C., U.S. Geological Survey.
Galloway, J.M., Haggard, B.E., Meyers, M.T., and Green, W.R., 2005, Occurrence of pharmaceuticals and other wastewater constituents in selected streams in northern Arkansas, 2004: U.S. Geological Survey Scientific Investigations Report 2005-5140, p. 2.

Galloway, J.M., and Green, W.R., 2006, Analysis of ambient conditions and simulation of hydrodynamics and waterquality characteristics in Beaver Lake, Arkansas, 2001 through 2003: U.S. Geological Survey Scientific Investigations Report 2006-5003, p. 2-5.

Griffis, V.W., and Stedinger, J.R., 2007, The use of GLS regression in regional hydrologic analyses: Journal of Hydrology, 344, p. 82-95.

Haley, B.R., and others, 1976, Geologic map of Arkansas: U.S. Geological Survey, 1 sheet.

Hardison, C.H., and Moss, M.E., 1972, Accuracy of low-flow characteristics estimated by correlation of base-flow measurements: U. S. Geological Survey Water-Supply Paper 1542-B, p. 25-55.

Helsel, D.R., and Hirsch, R.M., 2002, Statistical methods in water resources: U.S. Geological Survey Techniques of Water-Resources Investigations, book 4, chap. A3, 524 p.

Hines, M.S., 1965, Water-supply characteristics of selected Arkansas streams: Arkansas Geological Commission Water Resources Circular 9, 43 p.

Hines, M.S., 1975, Flow-duration and low-flow frequency determinations of selected Arkansas streams: Arkansas Geological Commission Water Resources Circular 12, 75 p.

Hines, M.S., and Yanchosek, J.J., 1978, Drainage areas of streams in Arkansas: U.S. Geological Survey Open-File Report 78-555, 42 p.

Hortness, J. E., 2006, Estimating low-flow frequency statistics for unregulated streams in Idaho: U.S. Geological Survey Scientific Investigations Report 2006-5035, 40 p.

Hunrichs, R.A., 1983, Identification and classification of perennial streams in Arkansas: U.S. Geological Survey Water-Resources Investigations Report 83-4063, 1 sheet.

Interagency Advisory Committee on Water Data, 1982, Guidelines for determining flood flow frequency: Bulletin 17B of the hydrology subcommittee, Office of Water Data Coordination, U.S. Geological Survey, Reston, Virginia, 99 p.

Ludwig, A.H., 1992, Flow duration and low-flow characteristics of selected Arkansas streams: U.S. Geological Survey Water-Resources Investigations Report 92-4026, 77 p. 
Ludwig, A.H., and Tasker, G.D., 1993, Regionalization of low-flow characteristics of Arkansas streams: U.S. Geological Survey Water-Resources Investigations Report 93-4013, $26 \mathrm{p}$.

Montgomery, D.C., Peck, E.A., and Vining, G.G., 2001, Introduction to linear regression analysis (3d ed.): New York, John Wiley and Sons, Inc., 641 p.

Ries, K.G., III, and Friesz, P.J., 2000, Methods for estimating low-flow statistics for Massachusetts streams: U.S. Geological Survey Water-Resources Investigations Report 00-4135, $81 \mathrm{p}$.

Riggs, H. C., 1972, Low-flow investigations: U.S. Geological Survey Techniques of Water-Resources Investigations, book 4, chap. B1, 18 p.

Schwartz, G.E., and Alexander, R.B., 1995, STATe Soil GeOgraphic (STATSGO) database for the conterminous United States: U.S. Geological Survey Open-File Report 95-449, $95 \mathrm{p}$.

Stedinger, J.R., and Tasker, G.D., 1985, Regional hydrologic analysis 1 - ordinary, weighted, and generalized least squares compared: Water Resources Research, v. 21, no. 9, p. 1421-1432.

Stedinger, J. R., and Thomas, W.O., Jr., 1985, Low-flow frequency estimation using base-flow measurements: U.S. Geological Survey Open-File Report 85-95, 22 p.

Tasker, G.D., 1980, Hydrologic regression with weighted least squares: Water Resources Research, v. 16, no. 6, p. 11071113.

Tasker, G. D., 1987, A comparison of methods for estimating low flow characteristics of streams: Water Resources Bulletin, v. 23, no. 6, 1077-1083.

Tasker, G.D., and Stedinger, J.R., 1986, Regional skew with weighted LS regression: Journal Water Resources Planning and Management, v. 112, no. 2, p. 225-237.

Tasker, G.D., and Stedinger, J.R., 1989, An operational GLS model for hydrologic regression: Journal of Hydrology, v. 111 , p. 361-375.

U.S. Department of Agriculture, 2001, STATe Soil GeOgraphic (STATSGO) database: Data use information: Natural Resources Conservation Service, National Soil Survey Center, Miscellaneous Publication No. 1492, 110 p. [Revised July 1994.]

U.S. Geological Survey, 1985, Office of Surface Water Technical Memorandum No. 86-02, accessed on October 2, 2007 at URL http://water.usgs.gov/admin/memo/SW/sw86.02. html.
Zecharias Y.B., and Brutsaert, W., 1988, Recession characteristics of groundwater outflow and base flow from mountainous watersheds: Water Resources Research, v. 24, no. 10, p. 1651-1658. 



\section{Tables 4-5}


Table 4. Low-flow characteristics for continuous streamflow-record gaging stations having 10 or more years of streamflow record.

07040000 St. Francis River at Fisk, Mo.

LOCATION.--Lat 364' 25.14", long 90²' 05" referenced to North American Datum of 1927, in NE 1/4 NW 1/4 sec.28, T.24 N., R.8 E., Butler County, Mo., Hydrologic Unit 08020203, at bridge on U.S. Hwy 60 at Fisk, Missouri.

DRAINAGE AREA.--1,370 square miles.

PERIOD OF RECORD.-- October 1997 to September 2005.

REMARKS.-- Numerous anthropogenic alterations within basin (highly altered).

Averaged consecutive seven-day minimum discharge, in cubic feet per second, and indicated recurrence interval

2-year recurrence interval

77.0 10-year recurrence interval

40.5

Averaged consecutive seven-day minimum discharge, in cubic feet per second, and 10-year recurrence interval

November-April

121
November-December

131
January-February

308
March-April

196

Averaged consecutive seven-day minimum discharge, in cubic feet per second, and 10-year recurrence interval

$\begin{array}{cccccc}\text { November } & \text { December } & \text { January } & \text { February } & \text { March } & \text { April } \\ 134 & 165 & 342 & 411 & 638 & 185\end{array}$

\section{St. Francis River at St. Francis, Ark.}

LOCATION.--Lat 36²7’21”, long 9008’13” referenced to North American Datum of 1927, in sec.18, T.21 N., R.9 E., Clay County, Ark., Hydrologic Unit 08020203, at bridge on U.S. Highway 62 at St. Francis, and at mile 229.

DRAINAGE AREA.--1,772 square miles.

PERIOD OF RECORD.-- April 1941 to September 1977, October 1989 to September 1990, October 1991 to September 1992, and October 1997 to September 2005.

REMARKS.-- Numerous anthropogenic alterations within basin (highly altered).

Averaged consecutive seven-day minimum discharge, in cubic feet per second, and indicated recurrence interval

2-year recurrence interval

122 10-year recurrence interval

74.2

Averaged consecutive seven-day minimum discharge, in cubic feet per second, and 10-year recurrence interval November-April

91.1
November-December

89.3
January-February

317
March-April

460

Averaged consecutive seven-day minimum discharge, in cubic feet per second, and 10-year recurrence interval

\section{November}

88.1
December

179
January

333
February

407
March

759
April

470 
Table 4. Low-flow characteristics for continuous streamflow-record gaging stations having 10 or more years of streamflow record.-Continued

07040450 St. Francis River at Lake City, Ark.

LOCATION.--Lat 3549'16”, long 90²5'56" referenced to North American Datum of 1927, in SE 1/4 sec.22, T.14 N., R.6 E., Craighead County, Ark., Hydrologic Unit 08020203, at bridge on State Highway 18 at Lake City, and at mile 173.6.

DRAINAGE AREA.--2,374 square miles.

PERIOD OF RECORD.--April 1941 to September 1977 and October 1999 to September 2005.

REMARKS.-- Numerous anthropogenic alterations within basin (highly altered).

Averaged consecutive seven-day minimum discharge, in cubic feet per second, and indicated recurrence interval

2-year recurrence interval

260 10-year recurrence interval

112

Averaged consecutive seven-day minimum discharge, in cubic feet per second, and 10-year recurrence interval

$\begin{array}{cccc}\text { November-April } & \text { November-December } & \text { January-February } & \text { March-April } \\ 146 & 144 & 523 & 930\end{array}$

Averaged consecutive seven-day minimum discharge, in cubic feet per second, and 10-year recurrence interval

$\begin{array}{cccccc}\text { November } & \text { December } & \text { January } & \text { February } & \text { March } & \text { April } \\ 142 & 301 & 575 & 671 & 1,410 & 928\end{array}$

07046600 Right Hand Chute of Little River at Rivervale, Ark.

LOCATION.--Lat 3540'20”, long 90²9'12”' in SW 1/4 sec. 10, T.12 N., R.7 E., Poinsett County, Hydrologic Unit 08020204, at bridge on State Highway 135 at Rivervale, 9.0 upstream from St. Francis River.

DRAINAGE AREA.--2,106 square miles.

PERIOD OF RECORD.--April 1947 to April 1977.

REMARKS.-- Numerous anthropogenic alterations within basin (highly altered).

Averaged consecutive seven-day minimum discharge, in cubic feet per second, and indicated recurrence interval

2-year recurrence interval

356 10-year recurrence interval

142

Averaged consecutive seven-day minimum discharge, in cubic feet per second, and 10-year recurrence interval

\section{November-April}

186

\section{November-December}

188
January-February

438
March-April

1,040

Averaged consecutive seven-day minimum discharge, in cubic feet per second, and 10-year recurrence interval

\section{November}

187

\section{December}

338
January

455
February

723
March

1,170 
Table 4. Low-flow characteristics for continuous streamflow-record gaging stations having 10 or more years of streamflow record.-Continued

07047500 St. Francis River at Marked Tree, Ark.

LOCATION.--Lat 35'31'20”, long 90 25’27’ in SE 1/4 NW 1/4 sec. 2, T.10 N., R.6 E., Poinsett County, Hydrologic Unit 08020203, near left bank on downstream side of bridge on U.S. Highway 63 at Marked Tree, 5. mi downstream from Little River, 7.6 mi downstream from dam of Poinsett County Drainage District 7, and at mile 147.0.

DRAINAGE AREA.--5,148 square miles.

PERIOD OF RECORD.--April 1941 to September 1973.

REMARKS.-- Numerous anthropogenic alterations within basin (highly altered).

Averaged consecutive seven-day minimum discharge, in cubic feet per second, and indicated recurrence interval

2-year recurrence interval

199

\section{0-year recurrence interval}

98.6

Averaged consecutive seven-day minimum discharge, in cubic feet per second, and 10-year recurrence interval

\section{November-April}

108

\section{November-December}

108
January-February

180
March-April

796

Averaged consecutive seven-day minimum discharge, in cubic feet per second, and 10-year recurrence interval

November

122

\section{December}

131
January

184
February

383
March

843
April 982

07047600 Tyronza River near Tyronza, Ark.

LOCATION.--Lat 35³0’18”, long 90²2’48”, Poinsett County, Hydrologic Unit 08020203, near Tyronza.

DRAINAGE AREA.--290 square miles.

PERIOD OF RECORD.--April 1949 to September 1974.

REMARKS.-- Numerous anthropogenic alterations within basin (highly altered).

Averaged consecutive seven-day minimum discharge, in cubic feet per second, and indicated recurrence interval

2-year recurrence interval

47.8 10-year recurrence interval 29.0

Averaged consecutive seven-day minimum discharge, in cubic feet per second, and 10-year recurrence interval

November-April

30.5
November-December

31.0
January-February

38.6
March-April

55.1

Averaged consecutive seven-day minimum discharge, in cubic feet per second, and 10-year recurrence interval

$\begin{array}{cccccc}\text { November } & \text { December } & \text { January } & \text { February } & \text { March } & \text { April } \\ 33.8 & 33.4 & 38.2 & 55.2 & 61.3 & 73.6\end{array}$


Table 4. Low-flow characteristics for continuous streamflow-record gaging stations having 10 or more years of streamflow record.-Continued

07047800 St. Francis River at Parkin, Ark.

LOCATION.--Lat 35¹6’23”, long 90³3’33” referenced to North American Datum of 1927, in NE 1/4 SE 1/4 sec.33, T.8 N., R.5 E., Cross County, Ark., Hydrologic Unit 08020203, at bridge on U.S. Highway 64 at Parkin, 1.1 mi downstream from Tyronza River, and at mile 102.0 .

DRAINAGE AREA.--Indeterminate. Total drainage area of St. Francis River and St. Francis Bay, 6,475 square miles.

PERIOD OF RECORD.--April 1941 to September 1982, October 1985 to September 1994, and October 1997 to September 2005.

REMARKS.-- Numerous anthropogenic alterations within basin (highly altered).

Averaged consecutive seven-day minimum discharge, in cubic feet per second, and indicated recurrence interval

2-year recurrence interval

409 10-year recurrence interval

98.7

Averaged consecutive seven-day minimum discharge, in cubic feet per second, and 10-year recurrence interval

$\begin{array}{cccc}\text { November-April } & \text { November-December } & \text { January-February } & \text { March-April } \\ 134 & 135 & 292 & 905\end{array}$

Averaged consecutive seven-day minimum discharge, in cubic feet per second, and 10-year recurrence interval

$\begin{array}{cccccc}\text { November } & \text { December } & \text { January } & \text { February } & \text { March } & \text { April } \\ 146 & 211 & 293 & 673 & 972 & 1,220\end{array}$

07047810 St. Francis River Floodway near Marked Tree, Ark.

LOCATION.--Lat 35³2'15”, long 90²9’05” in SE 1/4 NE 1/4 sec.31, T.11 N., R.6 E., Poinsett County, Hydrologic Unit 08020203, at bridge on U.S. Highway 63, 3.6 mi northwest of Marked Tree.

DRAINAGE AREA.--Undetermined.

PERIOD OF RECORD.--October 1934 to September 1970; October 1990 to September 2004.

REMARKS.-- Numerous anthropogenic alterations within basin (highly altered).

Averaged consecutive seven-day minimum discharge, in cubic feet per second, and indicated recurrence interval

2-year recurrence interval

0.00 10-year recurrence interval

0.00

Averaged consecutive seven-day minimum discharge, in cubic feet per second, and 10-year recurrence interval

$\begin{array}{cccc}\text { November-April } & \text { November-December } & \text { January-February } & \text { March-April } \\ 0.00 & 0.00 & 193 & 456\end{array}$

Averaged consecutive seven-day minimum discharge, in cubic feet per second, and 10-year recurrence interval

$\begin{array}{cccccc}\text { November } & \text { December } & \text { January } & \text { February } & \text { March } & \text { April } \\ 0.00 & 159 & 412 & 330 & 605 & 862\end{array}$


Table 4. Low-flow characteristics for continuous streamflow-record gaging stations having 10 or more years of streamflow record.-Continued

\section{St. Francis Bay at Riverfront, Ark.}

LOCATION.--Lat $35^{\circ} 15^{\prime} 34^{\prime \prime}$, long $90^{\circ} 40^{\prime} 48^{\prime \prime}$ referenced to North American Datum of 1927, in NW 1/4 NW 1/4 sec.4, T.7 N., R.4 E., Cross County, Ark., Hydrologic Unit 08020203, at bridge on U.S. Highway 64 at Riverfront, 7.0 mi west of Parkin.

DRAINAGE AREA.--Indeterminate. Total drainage area of St. Francis River and St. Francis Bay, 6,475 square miles.

PERIOD OF RECORD.--April 1941 to September 1982, October 1985 to September 1994, and October 1997 to September 2005.

REMARKS.-- Numerous anthropogenic alterations within basin (highly altered).

Averaged consecutive seven-day minimum discharge, in cubic feet per second, and indicated recurrence interval

2-year recurrence interval 10-year recurrence interval

Averaged consecutive seven-day minimum discharge, in cubic feet per second, and 10-year recurrence interval

$\begin{array}{cccc}\text { November-April } & \text { November-December } & \text { January-February } & \text { March-April } \\ 106 & 110 & 576 & 1,080\end{array}$

Averaged consecutive seven-day minimum discharge, in cubic feet per second, and 10-year recurrence interval

$\begin{array}{cccccc}\text { November } & \text { December } & \text { January } & \text { February } & \text { March } & \text { April } \\ 112 & 370 & 823 & 782 & 1,720 & 1,180\end{array}$

07047902 St. Francis River at Latitude of Wittsburg, Ark.

LOCATION.--Lat 35¹3’00”, long 90³8’00”, Cross County, Hydrologic Unit 08020203.

DRAINAGE AREA.--6,475 square miles, combined drainage area of St. Francis River at Parkin, and St. Francis Bay at Riverfront.

PERIOD OF RECORD.--January 1935 to Septbember 1977.

REMARKS.-- Numerous anthropogenic alterations within basin (highly altered).

Averaged consecutive seven-day minimum discharge, in cubic feet per second, and indicated recurrence interval

2-year recurrence interval

949

\section{0-year recurrence interval}

430

Averaged consecutive seven-day minimum discharge, in cubic feet per second, and 10-year recurrence interval
November-April
November-December
January-February
March-April
516
514
3,050

Averaged consecutive seven-day minimum discharge, in cubic feet per second, and 10-year recurrence interval

$\begin{array}{cccccc}\text { November } & \text { December } & \text { January } & \text { February } & \text { March } & \text { April } \\ 514 & 860 & 1,380 & 1,990 & 3,500 & 3,490\end{array}$


Table 4. Low-flow characteristics for continuous streamflow-record gaging stations having 10 or more years of streamflow record.-Continued

07047942 L'Anguille River near Colt, Ark.

LOCATION.--Lat 3508'40”, long 9052'40”' referenced to North American Datum of 1927, in NE 1/4 NW 1/4 sec.15, T.6 N., R.2 E., St Francis County, Ark., Hydrologic Unit 08020205, near center of span on downstream side of bridge on State Highway 306, 1.1 mi downstream form Lick Creek, 3.9 mi northwest of Colt, and at mile 52.8.

DRAINAGE AREA.--535 square miles.

PERIOD OF RECORD.--October 1970 to September 2005.

REMARKS.-- Numerous anthropogenic alterations within basin (highly altered).

Averaged consecutive seven-day minimum discharge, in cubic feet per second, and indicated recurrence interval

2-year recurrence interval

7.84 10-year recurrence interval

2.21

Averaged consecutive seven-day minimum discharge, in cubic feet per second, and 10-year recurrence interval

$\begin{array}{cccc}\text { November-April } & \text { November-December } & \text { January-February } & \text { March-April } \\ 4.86 & 4.51 & 44.6 & 39.4\end{array}$

Averaged consecutive seven-day minimum discharge, in cubic feet per second, and 10-year recurrence interval

$\begin{array}{cccccc}\text { November } & \text { December } & \text { January } & \text { February } & \text { March } & \text { April } \\ 4.73 & 26.7 & 54.2 & 115 & 92.5 & 46.1\end{array}$

07047950 L'Anguille River at Palestine, Ark.

LOCATION.--Lat 3458'20”, long 9053'10” referenced to North American Datum of 1983, in NW 1/4 sec.10, T.4 N., R.2 E., St Francis County, Ark., Hydrologic Unit 08020205, at bridge on U.S. Highway $701.0 \mathrm{mi}$ east of Palestine, and at mile 33.6.

DRAINAGE AREA.--786 square miles.

PERIOD OF RECORD.--April 1949 to September 1977 and October 1997 to September 2005.

REMARKS.-- Numerous anthropogenic alterations within basin (highly altered).

Averaged consecutive seven-day minimum discharge, in cubic feet per second, and indicated recurrence interval

2-year recurrence interval

2.70

\section{0-year recurrence interval}

0.00

Averaged consecutive seven-day minimum discharge, in cubic feet per second, and 10-year recurrence interval

\section{November-April}

0.00

\section{November-December}

0.00
January-February

48.3
March-April

38.9

Averaged consecutive seven-day minimum discharge, in cubic feet per second, and 10-year recurrence interval

\section{November}

0.00

\section{December}

2.26

\section{January}

53.7

\section{February}

168
March

202
April

41.2 
Table 4. Low-flow characteristics for continuous streamflow-record gaging stations having 10 or more years of streamflow record.-Continued

07048000 West Fork White River at Greenland, Ark.

LOCATION.--Lat $35^{\circ} 58^{\prime} 50^{\prime \prime}$, long 94 ${ }^{\circ} 10^{\prime} 05^{\prime \prime}$, in NW 1/4 sec. 16, T.15 N., R.30 W., Washington County, Hydrologic Unit 11010001, at highway bridge $800 \mathrm{ft}$ upstream of bridge on U.S. Highway 71, and 1.0 mi south of Greenland.

DRAINAGE AREA.--83.1 square miles.

PERIOD OF RECORD.--October 1945 to October 1983.

REMARKS.-- None.

Averaged consecutive seven-day minimum discharge, in cubic feet per second, and indicated recurrence interval

2-year recurrence interval

0.15
10 -year recurrence interval

0.00

Averaged consecutive seven-day minimum discharge, in cubic feet per second, and 10-year recurrence interval

\section{November - April}

0.00

\section{November - December}

0.00
January-February

2.57
March - April 12.5

Averaged consecutive seven-day minimum discharge, in cubic feet per second, and 10-year recurrence interval

November

0.00
December

0.73
January

2.69

\section{February}

10.3
March

14.1
April

21.4

\section{White River near Fayetteville, Ark.}

LOCATION.--Lat 3604'23”, long 9404'52” referenced to North American Datum of 1927, in NE 1/4 SW 1/4 sec.8, T.16 N., R.29 W., Washington County, Ark., Hydrologic Unit 11010001, on left abutment, downstream side of bridge, 0.6 mi downstream from West Fork White River, 0.8 mi downstream from Lake Sequoyah Dam on White River, 4.3 mi east of Fayetteville and at mile 684.0.

DRAINAGE AREA.--400 square miles.

PERIOD OF RECORD.--October 1963 to December 1994 , October 1998 to September 2005.

REMARKS.----None.

Averaged consecutive seven-day minimum discharge, in cubic feet per second, and indicated recurrence interval

2-year recurrence interval

3.23 10-year recurrence interval

0.80

Averaged consecutive seven-day minimum discharge, in cubic feet per second, and 10-year recurrence interval
November - April
November - December
January-February
March - April
3.68
3.79
24.4
67.5

Averaged consecutive seven-day minimum discharge, in cubic feet per second, and 10-year recurrence interval

$\begin{array}{cccccc}\text { November } & \text { December } & \text { January } & \text { February } & \text { March } & \text { April } \\ 3.68 & 15.1 & 24.3 & 53.8 & 81.6 & 128\end{array}$


Table 4. Low-flow characteristics for continuous streamflow-record gaging stations having 10 or more years of streamflow record.-Continued

07049000 War Eagle Creek near Hindsville, Ark.

LOCATION.--Lat $36^{\circ} 12^{\prime} 00^{\prime \prime}$, long 93 ${ }^{\circ} 1^{\prime}$ '18” referenced to North American Datum of 1927, in SW 1/4 SE 1/4 NE 1/4 sec.28, T.18 N., R.27 W., Madison County, Ark., Hydrologic Unit 11010001, on left bank about $800 \mathrm{ft}$ above bridge on State Highway 45, 3.9 mi north of Hindsville, and at mile 22.4 .

DRAINAGE AREA.--263 square miles.

PERIOD OF RECORD.--July 1952 to September 1970, October 1998 to September 2005.

REMARKS.-- --None.

Averaged consecutive seven-day minimum discharge, in cubic feet per second, and indicated recurrence interval

2-year recurrence interval

10.1

\section{0-year recurrence interval}

$$
2.22
$$

Averaged consecutive seven-day minimum discharge, in cubic feet per second, and 10-year recurrence interval

\section{November-April}

6.37

\section{November-December}

6.48
January-February

13.1
March-April

36.6

Averaged consecutive seven-day minimum discharge, in cubic feet per second, and 10-year recurrence interval

$\begin{array}{cccccc}\text { November } & \text { December } & \text { January } & \text { February } & \text { March } & \text { April } \\ 6.45 & 10.7 & 13.6 & 26.6 & 42.8 & 56.4\end{array}$

07049500 Beaver Lake at Highway 12 Bridge near Rogers, Ark.

LOCATION.--Lat $36^{\circ} 19^{\prime} 56^{\prime \prime}$, long 9401'08” in SE 1/4 NW 1/4 sec.12, T.19 N., R.29 W., Benton County, Hydrologic Unit 11010001, at bridge on State Highway 12, 5.3 mi east of Rogers.

DRAINAGE AREA.--1,020 square miles.

PERIOD OF RECORD.--October 1952 to September 1963.

REMARKS.-- Highly regulated (highly altered). Prior to 1964 published as White River near Rogers.

Averaged consecutive seven-day minimum discharge, in cubic feet per second, and indicated recurrence interval

2-year recurrence interval

37.9 10-year recurrence interval

6.83

Averaged consecutive seven-day minimum discharge, in cubic feet per second, and 10-year recurrence interval
November-April
November-December
January-February
March-April
25.4
24.8
48.0
173

Averaged consecutive seven-day minimum discharge, in cubic feet per second, and 10-year recurrence interval

$\begin{array}{cccccc}\text { November } & \text { December } & \text { January } & \text { February } & \text { March } & \text { April } \\ 24.3 & 43.5 & 47.6 & 146 & 211 & 235\end{array}$


Table 4. Low-flow characteristics for continuous streamflow-record gaging stations having 10 or more years of streamflow record.-Continued

07050000 White River at Beaver, Ark.

LOCATION.--Lat $36^{\circ} 28^{\prime} 28^{\prime \prime}$, long 93 ${ }^{\circ} 45^{\prime} 54^{\prime \prime}$ in NE 1/4 SE 1/4 sec.20, T.21 N., R.26 W., Carroll County, Hydrologic Unit 11010001, at bridge on State Highway 187, 0.4 mi downstream from Butler Creek, and 13 mi downstream from Beaver Dam.

DRAINAGE AREA.--1,244 square miles.

PERIOD OF RECORD.--October 1909 to September 1958.

REMARKS.-- Highly regulated (highly altered).

Averaged consecutive seven-day minimum discharge, in cubic feet per second, and indicated recurrence interval

2-year recurrence interval

61.0 10-year recurrence interval

12.5

Averaged consecutive seven-day minimum discharge, in cubic feet per second, and 10-year recurrence interval

\section{November-April}

48.7

\section{November-December}

46.3

\section{January-February}

96.9
March-April

239

Averaged consecutive seven-day minimum discharge, in cubic feet per second, and 10-year recurrence interval

November

45.3

\section{December}

72.1

\begin{abstract}
January
\end{abstract}
105

\section{February}

161

\begin{abstract}
March
\end{abstract}
260
April 358

07050500 Kings River near Berryville, Ark.

LOCATION.--Lat 36²5’38”, long 93³7’15” referenced to North American Datum of 1983, in SE 1/4 NE 1/4 sec.3, T.20 N., R.25 W., Carroll County, Ark., Hydrologic Unit 11010001, on right downstream end of new bridge on State Highway 143, 1.5 mi downstream from Bee Creek, 2.5 mi upstream from Clabber Creek, 5.3 mi northwest of Berryville and at mile 35.1.

DRAINAGE AREA.--527 square miles.

PERIOD OF RECORD.--April 1939 to September 1975, October 1992 to September 1995 , October 1998 to September 2005.

REMARKS.-- None.

Averaged consecutive seven-day minimum discharge, in cubic feet per second, and indicated recurrence interval

2-year recurrence interval

12.1 10-year recurrence interval

Averaged consecutive seven-day minimum discharge, in cubic feet per second, and 10-year recurrence interval
November-April
November-December
January-February
March-April
11.8
11.6
36.7
80.0

Averaged consecutive seven-day minimum discharge, in cubic feet per second, and 10-year recurrence interval November

December

January

February

March

April

11.2

25.4

38.4

63.3

93.6 
Table 4. Low-flow characteristics for continuous streamflow-record gaging stations having 10 or more years of streamflow record.-Continued

07053250 Yocum Creek near Oak Grove, Ark.

LOCATION.--Lat 36 27'17', long 9321'21' referenced to North American Datum of 1927, in NE 1/4 SW 1/4 NE 1/4 sec.30, T.21 N., R.22 W., Carroll County, Ark., Hydrologic Unit 11010001, on right bank $50 \mathrm{ft}$ upstream from County Road 86, 0.4 mi upstream from Spring Creek, 1.2 mi downstream from Stillhouse Creek, and 4.7 mi east of Oak Grove.

DRAINAGE AREA.--52.8 square miles.

PERIOD OF RECORD.--May 1993 to September 2005.

REMARKS.-- None.

Averaged consecutive seven-day minimum discharge, in cubic feet per second, and indicated recurrence interval

2-year recurrence interval

5.85 10-year recurrence interval

3.80

Averaged consecutive seven-day minimum discharge, in cubic feet per second, and 10-year recurrence interval

\section{November-April}

4.24

\section{November-December}

5.19
January-February

6.96
March-April

10.7

Averaged consecutive seven-day minimum discharge, in cubic feet per second, and 10-year recurrence interval

$\begin{array}{llcccc}\text { November } & \text { December } & \text { January } & \text { February } & \text { March } & \text { April } \\ 4.99 & 7.51 & 10.7 & 7.91 & 11.5 & 12.5\end{array}$

07055000 White River near Flippin, Ark.

LOCATION.--Lat $36^{\circ} 18^{\prime} 35^{\prime \prime}$, long 92 $33^{\prime} 28^{\prime \prime}$ in NE 1/4 NW 1/4 sec.10, T.19 N., R.15 W., Marion County, Hydrologic Unit 11010003, on right bank 1.4 mi upstream from Hightower Creek, 3.2 mi northeast of Flippin.

DRAINAGE AREA.--6,081square miles.

PERIOD OF RECORD.--January 1964 to September 1980.

REMARKS.-- Highly regulated (highly altered).

Averaged consecutive seven-day minimum discharge, in cubic feet per second, and indicated recurrence interval

2-year recurrence interval

736

\section{0-year recurrence interval}

410

Averaged consecutive seven-day minimum discharge, in cubic feet per second, and 10-year recurrence interval

\section{November-April}

374
November-December

508
January-February

625
March-April

531

Averaged consecutive seven-day minimum discharge, in cubic feet per second, and 10-year recurrence interval

$\begin{array}{lllllr}\text { November } & \text { December } & \text { January } & \text { February } & \text { March } & \text { April } \\ 659 & 619 & 930 & 631 & 912 & 704\end{array}$


Table 4. Low-flow characteristics for continuous streamflow-record gaging stations having 10 or more years of streamflow record.-Continued

07055875 Richland Creek near Witts Spring, Ark.

LOCATION.--Lat 3547'49”, long 9255'43” referenced to North American Datum of 1927, in SE 1/4 SE 1/4 SE 1/4 sec.6, T.13 N., R.18 W., Searcy County, Ark., Hydrologic Unit 11010005, $50 \mathrm{ft}$ upstream from bridge on county road, 1,800 ft downstream from Falling Water Creek and 3.9 mi northwest of Witts Spring.

DRAINAGE AREA.--67.4 square miles.

PERIOD OF RECORD.--June 1995 to September 2005.

REMARKS.-- None.

Averaged consecutive seven-day minimum discharge, in cubic feet per second, and indicated recurrence interval

2-year recurrence interval

0.12 10-year recurrence interval

0.00

Averaged consecutive seven-day minimum discharge, in cubic feet per second, and 10-year recurrence interval

$\begin{array}{cccc}\text { November-April } & \text { November-December } & \text { January-February } & \text { March-April } \\ 2.02 & 2.18 & 8.85 & 21.5\end{array}$

Averaged consecutive seven-day minimum discharge, in cubic feet per second, and 10-year recurrence interval

$\begin{array}{cccccc}\text { November } & \text { December } & \text { January } & \text { February } & \text { March } & \text { April } \\ 2.04 & 10.4 & 9.95 & 9.97 & 22.6 & 28.8\end{array}$

07056000 Buffalo River near St. Joe, Ark.

LOCATION.--Lat 3558'59.01”, long 9244’49.67” referenced to North American Datum of 1983, in SW 1/4 SW 1/4 sec.36, T.16 N., R.17 W., Searcy County, Ark., Hydrologic Unit 11010005, near right bank on downstream side of bridge on U.S. Highway 65, 1.2 mi downstream from Mill Creek, 4.0 mi upstream from Bear Creek, 4.5 mi southeast of St. Joe, and at mile 58.3.

DRAINAGE AREA.--829 square miles.

PERIOD OF RECORD.--October 1939 to September 2005.

REMARKS.-- None.

Averaged consecutive seven-day minimum discharge, in cubic feet per second, and indicated recurrence interval

2-year recurrence interval

34.1 10-year recurrence interval

16.8

Averaged consecutive seven-day minimum discharge, in cubic feet per second, and 10-year recurrence interval

\section{November-April}

28.2
November-December

27.6
January-February

77.4
March-April

192

Averaged consecutive seven-day minimum discharge, in cubic feet per second, and 10-year recurrence interval

$\begin{array}{lllllr}\text { November } & \text { December } & \text { January } & \text { February } & \text { March } & \text { April } \\ 26.7 & 52.3 & 82.8 & 145 & 218 & 300\end{array}$


Table 4. Low-flow characteristics for continuous streamflow-record gaging stations having 10 or more years of streamflow record.-Continued

\section{Buffalo River near Rush}

LOCATION.--Lat 36 $11^{\prime} 72^{\prime \prime}$, long 92 $55^{\prime} 44^{\prime \prime}$, in NE 1/4 sec. 15, T.17 N., R.15 W., Marion County, Hydrologic Unit 11010005, 3.2 mi east of State Highway 14, and 1.4 mi southeast of Rush.

DRAINAGE AREA.--1,100 square miles.

PERIOD OF RECORD.--October 1928 to September 1970.

REMARKS.-- None.

Averaged consecutive seven-day minimum discharge, in cubic feet per second, and indicated recurrence interval

2-year recurrence interval

59.0 10-year recurrence interval

26.0

Averaged consecutive seven-day minimum discharge, in cubic feet per second, and 10-year recurrence interval

$\begin{array}{cccc}\text { November-April } & \text { November-December } & \text { January-February } & \text { March-April } \\ 48.6 & 47.9 & 105 & 227\end{array}$

Averaged consecutive seven-day minimum discharge, in cubic feet per second, and 10-year recurrence interval

$\begin{array}{lllccc}\text { November } & \text { December } & \text { January } & \text { February } & \text { March } & \text { April } \\ 47.6 & 76.1 & 110 & 167 & 246 & 374\end{array}$

07059000 Norfork Lake near Henderson

LOCATION.--Lat $36^{\circ} 22^{\prime} 20^{\prime \prime}$, long $92^{\circ} 14^{\prime} 25^{\prime \prime}$

DRAINAGE AREA.--1,610 square miles.

PERIOD OF RECORD.--October 1928 to April 1943.

REMARKS.-- None.

Averaged consecutive seven-day minimum discharge, in cubic feet per second, and indicated recurrence interval

2-year recurrence interval

451 10-year recurrence interval

359

Averaged consecutive seven-day minimum discharge, in cubic feet per second, and 10-year recurrence interval

\section{November-April}

401

\section{November-December}

392
January-February

492
March-April

599

Averaged consecutive seven-day minimum discharge, in cubic feet per second, and 10-year recurrence interval

$\begin{array}{llcccr}\text { November } & \text { December } & \text { January } & \text { February } & \text { March } & \text { April } \\ 402 & 424 & 521 & 521 & 610 & 715\end{array}$


Table 4. Low-flow characteristics for continuous streamflow-record gaging stations having 10 or more years of streamflow record.-Continued

07060000 North Fork River at Norfork Dam near Norfork, Ark.

LOCATION.--Lat 36 $14^{\prime} 18^{\prime \prime}$, long 92 ${ }^{\circ} 14^{\prime} 18^{\prime \prime}$ in SE 1/4 SW 1/4 sec.2, T.18 N., R.12 W., Baxter County, Hydrologic Unit 11010006, at Norfolk Dam, 3.9 mi northeast of Norfork, and at mile 4.8 .

DRAINAGE AREA.--1,808 square miles.

PERIOD OF RECORD.--October 1944 to September 1977.

REMARKS.-- Highly regulated (highly altered).

Averaged consecutive seven-day minimum discharge, in cubic feet per second, and indicated recurrence interval

2-year recurrence interval

311 10-year recurrence interval

30.7

Averaged consecutive seven-day minimum discharge, in cubic feet per second, and 10-year recurrence interval

$\begin{array}{cccc}\text { November-April } & \text { November-December } & \text { January-February } & \text { March-April } \\ 39.0 & 117 & 63.2 & 189\end{array}$

Averaged consecutive seven-day minimum discharge, in cubic feet per second, and 10-year recurrence interval

$\begin{array}{lllllr}\text { November } & \text { December } & \text { January } & \text { February } & \text { March } & \text { April } \\ 197 & 181 & 77.7 & 94.3 & 220 & 252\end{array}$

07060500 White River at Calico Rock, Ark.

LOCATION.--Lat 3606'58”, long 9208’35” referenced to North American Datum of 1927, in SE 1/4 NE 1/4 sec.22, T.17 N., R.11 W., Izard County, Ark., Hydrologic Unit 11010004, on left bank at Calico Rock, $200 \mathrm{ft}$ upstream from bridge on State Highway 5, $700 \mathrm{ft}$ upstream from Calico Creek, 3.2 mi downstream from Cataract Creek, 6.0 mi upstream from Piney Creek, and at mile 359.1.

DRAINAGE AREA.--9,978 square miles.

PERIOD OF RECORD.--January 1964 to September 2005.

REMARKS.-- Highly regulated (highly altered).

Averaged consecutive seven-day minimum discharge, in cubic feet per second, and indicated recurrence interval

2-year recurrence interval

1,830 10-year recurrence interval

977

Averaged consecutive seven-day minimum discharge, in cubic feet per second, and 10-year recurrence interval

\section{November-April}

1,050
November-December

1,080
January-February

1,730
March-April

1,950

Averaged consecutive seven-day minimum discharge, in cubic feet per second, and 10-year recurrence interval

$\begin{array}{cccccc}\text { November } & \text { December } & \text { January } & \text { February } & \text { March } & \text { April } \\ 1,320 & 1,260 & 1,850 & 2,380 & 2,730 & 2,360\end{array}$


Table 4. Low-flow characteristics for continuous streamflow-record gaging stations having 10 or more years of streamflow record.-Continued

07060710 North Sylamore Creek near Fifty Six, Ark.

LOCATION.--Lat 35'59'30”, long 92 ${ }^{\circ} 12^{\prime} 50^{\prime \prime}$ referenced to North American Datum of 1927, in SW 1/4 NW 1/4 sec.25, T.16 N., R.12 W., Stone County, Ark., Hydrologic Unit 11010004, on right bank $30 \mathrm{ft}$ upstream from bridge on Ozark National Forest service road, $200 \mathrm{ft}$ downstream from Gunner Creek, 2.7 mi north of Fifty-Six, and 7.0 mi upstream from South Sylamore Creek.

DRAINAGE AREA.--58.1 square miles.

PERIOD OF RECORD.--January 1966 to September 2005.

REMARKS.-- None.

Averaged consecutive seven-day minimum discharge, in cubic feet per second, and indicated recurrence interval

2-year recurrence interval

2.93 10-year recurrence interval

1.81

Averaged consecutive seven-day minimum discharge, in cubic feet per second, and 10-year recurrence interval
November-April
November-December
3.13
January-February
4.36
March-April
6.36

Averaged consecutive seven-day minimum discharge, in cubic feet per second, and 10-year recurrence interval

$\begin{array}{cccccc}\text { November } & \text { December } & \text { January } & \text { February } & \text { March } & \text { April } \\ 3.25 & 4.01 & 4.50 & 6.07 & 6.93 & 8.36\end{array}$

\section{White River at Batesville, Ark.}

LOCATION.--Lat 35³4’35”, long 91³8’28” referenced to North American Datum of 1927, Independence County, Ark., Hydrologic Unit 11010004, at highway bridge on State Highway 167 (old State Highway 11), at south edge of Batesville, Independence County, Hydrologic Unit 11010004, 0.25 mi above Lock \& Dam No. 1, 1.0 mi below Polk Bayou, $32.0 \mathrm{mi}$ above mouth of Black River,and about 179 mi upstream from gaging station at DeValls Bluff.

DRAINAGE AREA.--11,070 square miles.

PERIOD OF RECORD.--October 1986 to September 1994 and October 2000 to September 2005.

REMARKS.-- Highly regulated (highly altered).

Averaged consecutive seven-day minimum discharge, in cubic feet per second, and indicated recurrence interval

2-year recurrence interval 2,350
10 -year recurrence interval

1,150

Averaged consecutive seven-day minimum discharge, in cubic feet per second, and 10-year recurrence interval

\section{November-April}

1,130
November-December

1,360

\section{January-February}

1,970
March-April

3,020

Averaged consecutive seven-day minimum discharge, in cubic feet per second, and 10-year recurrence interval

$\begin{array}{cccccc}\text { November } & \text { December } & \text { January } & \text { February } & \text { March } & \text { April } \\ 1,610 & 1,870 & 2,070 & 4,470 & 4,880 & 3,250\end{array}$


Table 4. Low-flow characteristics for continuous streamflow-record gaging stations having 10 or more years of streamflow record.-Continued

07064000 Black River near Corning, Ark.

LOCATION.--Lat 36²4'07”, long 90³2'29” referenced to North American Datum of 1927, in SW 1/4 NE 1/4 sec.4, T.20 N., R.5 E., Clay County, Ark., Hydrologic Unit 11010007, near left bank on downstream side of bridge on U.S. Highway 62, 2.2 mi east of Corning, 11.9 mi downstream from Cane Creek, and at mile 152.2.

DRAINAGE AREA.--1,749 square miles.

PERIOD OF RECORD.--June 1948 to September 1995 and October 1998 to September 2005.

REMARKS.-- Highly regulated (highly altered).

Averaged consecutive seven-day minimum discharge, in cubic feet per second, and indicated recurrence interval

2-year recurrence interval

370

\section{0-year recurrence interval}

272

Averaged consecutive seven-day minimum discharge, in cubic feet per second, and 10-year recurrence interval

$\begin{array}{cccc}\text { November-April } & \text { November-December } & \text { January-February } & \text { March-April } \\ 324 & 315 & 444 & 645\end{array}$

Averaged consecutive seven-day minimum discharge, in cubic feet per second, and 10-year recurrence interval

$\begin{array}{cccccc}\text { November } & \text { December } & \text { January } & \text { February } & \text { March } & \text { April } \\ 315 & 384 & 452 & 546 & 759 & 724\end{array}$

07069000 Black River at Pocahontas

LOCATION.--Lat 36¹5'14”, long 9058'12” referenced to North American Datum of 1927, in SW 1/4 SW 1/4 sec.27, T.19 N., R.1 E., Randolph County, Ark., Hydrologic Unit 11010009, near right bank on downstream side of bridge on U.S. Highway 67 at Pocahontas, 2.2 mi downstream from Fourche River, 6.4 mi downstream from Current River, 18.1 mi upstream from Spring River, and at mile 90.1.

DRAINAGE AREA.--4,845 square miles.

PERIOD OF RECORD.--January 1936 to April 1948.

REMARKS.-- Highly regulated after 1948 (highly altered).

Averaged consecutive seven-day minimum discharge, in cubic feet per second, and indicated recurrence interval

2-year recurrence interval

1,620 10-year recurrence interval 1,310

Averaged consecutive seven-day minimum discharge, in cubic feet per second, and 10-year recurrence interval
November-April
November-December
January-February
March-April
1,510
1,480
1,770
2,310

Averaged consecutive seven-day minimum discharge, in cubic feet per second, and 10-year recurrence interval

$\begin{array}{cccccc}\text { November } & \text { December } & \text { January } & \text { February } & \text { March } & \text { April } \\ 1,450 & 1,610 & 1,780 & 1,660 & 2,240 & 3,600\end{array}$


Table 4. Low-flow characteristics for continuous streamflow-record gaging stations having 10 or more years of streamflow record.-Continued

07069000 Black River at Pocahontas, Ark.

LOCATION.--Lat 36 15'14”, long 9058'12”' referenced to North American Datum of 1927, in SW 1/4 SW 1/4 sec.27, T.19 N., R.1 E., Randolph County, Ark., Hydrologic Unit 11010009, near right bank on downstream side of bridge on U.S. Highway 67 at Pocahontas, 2.2 mi downstream from Fourche River, 6.4 mi downstream from Current River, 18.1 mi upstream from Spring River, and at mile 90.1.

DRAINAGE AREA.--4,845 square miles.

PERIOD OF RECORD.--May 1948 to September 1970, October 2001 to September 2005.

REMARKS.-- Highly regulated after 1948.

Averaged consecutive seven-day minimum discharge, in cubic feet per second, and indicated recurrence interval

2-year recurrence interval

$$
1,670
$$

\section{0-year recurrence interval}

1,280

Averaged consecutive seven-day minimum discharge, in cubic feet per second, and 10-year recurrence interval

\section{November-April}

1,390
November-December

1,390
January-February

1,570
March-April

2,460

Averaged consecutive seven-day minimum discharge, in cubic feet per second, and 10-year recurrence interval

$\begin{array}{cccccc}\text { November } & \text { December } & \text { January } & \text { February } & \text { March } & \text { April } \\ 1,390 & 1,510 & 1,590 & 2,040 & 2.710 & 2,920\end{array}$

\section{Mammoth Spring at Mammoth Spring, Ark.}

LOCATION.--Lat 36²9’53”, long 91³2’08”, in SE 1/4 SW 1/4 sec.5, T.21 N., R.5 W., Fulton County, Ark., Hydrologic Unit 11010010, at north bank of spring outlet pool, 0.25 mi upstream from confluence of Mammoth Spring and Warm Fork at town of Mammoth Spring, Ark.

DRAINAGE AREA.--undetermined.

PERIOD OF RECORD.-- March 1981 to September 2005.

REMARKS.-- Numerous anthropogenic alterations within basin (highly altered).

Averaged consecutive seven-day minimum discharge, in cubic feet per second, and indicated recurrence interval

2-year recurrence interval

\section{0-year recurrence interval}

192

Averaged consecutive seven-day minimum discharge, in cubic feet per second, and 10-year recurrence interval

$\begin{array}{cccc}\text { November-April } & \text { November-December } & \text { January-February } & \text { March-April } \\ 187 & 187 & 215 & 253\end{array}$

Averaged consecutive seven-day minimum discharge, in cubic feet per second, and 10-year recurrence interval

$\begin{array}{cccccc}\text { November } & \text { December } & \text { January } & \text { February } & \text { March } & \text { April } \\ 193 & 193 & 215 & 256 & 269 & 267\end{array}$


Table 4. Low-flow characteristics for continuous streamflow-record gaging stations having 10 or more years of streamflow record.-Continued

07069500 Spring River at Imboden, Ark.

LOCATION.--Lat $36^{\circ} 12^{\prime} 19^{\prime \prime}$, long 91 ${ }^{\circ} 10^{\prime} 19^{\prime \prime}$ referenced to North American Datum of 1927, in SE 1/4 NE 1/4 sec.15, T.18 N., R.2 W., Randolph County, Ark., Hydrologic Unit 11010010, near left bank on downstream side of bridge on U.S. Highway 62 at Imboden, $1.8 \mathrm{mi}$ upstream from Harding Creek, 3.9 mi downstream from Janes Creek, 8.2 mi upstream from Eleven Point River, and at mile 12.1.

DRAINAGE AREA.--1,183 square miles.

PERIOD OF RECORD.--April 1936 to September 1994, October 2001 to September 2003, and October 2004 to September 2005.

REMARKS.-- Numerous anthropogenic alterations within basin (highly altered).

Averaged consecutive seven-day minimum discharge, in cubic feet per second, and indicated recurrence interval

2-year recurrence interval

380 10-year recurrence interval

287

Averaged consecutive seven-day minimum discharge, in cubic feet per second, and 10-year recurrence interval

$\begin{array}{cccc}\text { November-April } & \text { November-December } & \text { January-February } & \text { March-April } \\ 306 & 308 & 360 & 549\end{array}$

Averaged consecutive seven-day minimum discharge, in cubic feet per second, and 10-year recurrence interval

$\begin{array}{cccccc}\text { November } & \text { December } & \text { January } & \text { February } & \text { March } & \text { April } \\ 308 & 332 & 366 & 453 & 590 & 642\end{array}$

\section{Black River at Black Rock, Ark.}

LOCATION.--Lat 3606'15”, long 91 05' 50” referenced to North American Datum of 1927, in NW 1/4 sec.21, T.17 N., R.1 W., Lawrence County, Ark., Hydrologic Unit 11010009, on right bank beneath U.S. Highway 63 bridge at Black Rock, 3.7 mi downstream from Spring River, and at mile 69.3.

DRAINAGE AREA.--7,369 square miles.

PERIOD OF RECORD.-- June 1948 to September 2005.

REMARKS.-- Highly regulated (highly altered).

Averaged consecutive seven-day minimum discharge, in cubic feet per second, and indicated recurrence interval

2-year recurrence interval

2,720 10-year recurrence interval

$$
2,060
$$

Averaged consecutive seven-day minimum discharge, in cubic feet per second, and 10-year recurrence interval
November-April
November-December
January-February
March-April
2,130
2,120
2,620
3,920

Averaged consecutive seven-day minimum discharge, in cubic feet per second, and 10-year recurrence interval

$\begin{array}{cccccc}\text { November } & \text { December } & \text { January } & \text { February } & \text { March } & \text { April } \\ 2,120 & 2,310 & 2,700 & 3,250 & 4,400 & 4,500\end{array}$


Table 4. Low-flow characteristics for continuous streamflow-record gaging stations having 10 or more years of streamflow record.-Continued

07073000 Strawberry River near Evening Shade, Ark.

LOCATION.--Lat 36 $10^{\prime} 41^{\prime \prime}$, long 91 ${ }^{\circ} 44^{\prime} 19^{\prime \prime}$, in NW 1/4 sec. 33, T.18 N., R.7 W., Izard County, Hydrologic Unit 11010012, at bridge on State Highway 56, 2.1 mi east of Franklin.

DRAINAGE AREA.--155 square miles.

PERIOD OF RECORD.--March 1939 to September 1979.

REMARKS.-- None.

Averaged consecutive seven-day minimum discharge, in cubic feet per second, and indicated recurrence interval

2-year recurrence interval

10.5 10-year recurrence interval

61.6

Averaged consecutive seven-day minimum discharge, in cubic feet per second, and 10-year recurrence interval
November-April
November-December
January-February
March-April
7.88
7.74
16.0
36.4

Averaged consecutive seven-day minimum discharge, in cubic feet per second, and 10-year recurrence interval

$\begin{array}{cccccc}\text { November } & \text { December } & \text { January } & \text { February } & \text { March } & \text { April } \\ 7.58 & 12.6 & 17.5 & 26.8 & 42.8 & 44.3\end{array}$

07073500 Piney Fork at Evening Shade, Ark.

LOCATION.--Lat $36^{\circ} 04^{\prime} 50^{\prime \prime}$, long 91³6'39”, in SE 1/4 NE 1/4 sec.34, T.17 N., R.6 W., Sharp County, Hydrologic Unit 11010012, on right bank, $20 \mathrm{ft}$ upstream from bridge on U.S. Highway 167, 0.8 mi north of Evening Shade.

DRAINAGE AREA.--99.2 square miles.

PERIOD OF RECORD.--March 1939 to November 1984.

REMARKS.-- None.

Averaged consecutive seven-day minimum discharge, in cubic feet per second, and indicated recurrence interval

2-year recurrence interval

2.43 10-year recurrence interval

0.16

Averaged consecutive seven-day minimum discharge, in cubic feet per second, and 10-year recurrence interval
November-April
November-December
1.75
January-February
March-April
1.79
6.08
16.9

Averaged consecutive seven-day minimum discharge, in cubic feet per second, and 10-year recurrence interval

$\begin{array}{cccccc}\text { November } & \text { December } & \text { January } & \text { February } & \text { March } & \text { April } \\ 1.80 & 4.17 & 6.54 & 12.4 & 20.4 & 21.0\end{array}$


Table 4. Low-flow characteristics for continuous streamflow-record gaging stations having 10 or more years of streamflow record.-Continued

07074000 Strawberry River near Poughkeepsie, Ark.

LOCATION.--Lat 3607'37”, long 91²6'59”, in SE 1/4 NW 1/4 sec. 19, T.17 N., R.4 W., Sharp County, Hydrologic Unit 11010012, on left bank $250 \mathrm{ft}$ upstream of bridge on State Highway 58, 0.5 mi downstream from Hurricane Creek, 2.5 mi northeast of Poughkeepsie, and at mile 35.9.

DRAINAGE AREA.--473 square miles.

PERIOD OF RECORD.--April 1936 to September 1994, October 2001 to September 2004.

REMARKS.-- None.

Averaged consecutive seven-day minimum discharge, in cubic feet per second, and indicated recurrence interval

2-year recurrence interval

53.5 10-year recurrence interval

41.7

Averaged consecutive seven-day minimum discharge, in cubic feet per second, and 10-year recurrence interval
November-April
November-December
January-February
March-April
48.6
48.1
75.2
131

Averaged consecutive seven-day minimum discharge, in cubic feet per second, and 10-year recurrence interval

$\begin{array}{cccccc}\text { November } & \text { December } & \text { January } & \text { February } & \text { March } & \text { April } \\ 47.9 & 62.5 & 78.5 & 113 & 153 & 155\end{array}$

\section{White River at Newport, Ark.}

LOCATION.--Lat 35³6'18”, long 91¹7'19”' referenced to North American Datum of 1983, in NE 1/4 NE 1/4 sec.10, T.11 N., R.3 W., Jackson County, Ark., Hydrologic Unit 11010013, The gage is approximately $60 \mathrm{ft}$ below the State Highway 367 bridge, which crosses the White River at Newport. This is at river mile 254.7 on the White River (from maps of White River, May 1973).

DRAINAGE AREA.--19,860 square miles.

PERIOD OF RECORD.--January 1964 to September 2005.

REMARKS.-- Highly regulated (highly altered).

Averaged consecutive seven-day minimum discharge, in cubic feet per second, and indicated recurrence interval

2-year recurrence interval

$$
6,270
$$

10-year recurrence interval

4,190

Averaged consecutive seven-day minimum discharge, in cubic feet per second, and 10-year recurrence interval

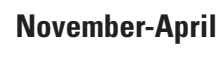

4,290

\begin{abstract}
A
\end{abstract} November

Averaged consecutive seven-day minimu
December 5,290

\begin{abstract}
November-December
\end{abstract} 4,290
January-February 6,070
March-April

8,490
4,410

5,290

\begin{abstract}
January
\end{abstract}
6,350

$\sqrt{2}$


Table 4. Low-flow characteristics for continuous streamflow-record gaging stations having 10 or more years of streamflow record.-Continued

\section{Middle Fork Little Red River at Shirley}

LOCATION.--Lat 35'39'25", long 92 '17'34", in SW1/4SW1/4, sec.20, T.12 N, R.11 W., Van Buren County, Hydrologic Unit 11010014, on right bank 05 mi downstream from Sugar Camp or Weavers Creek, 1.0 mi east of Shirley, and at mile 122.0.

DRAINAGE AREA.--302 square miles.

PERIOD OF RECORD.-March 1939 to September 1984.

REMARKS.-- None.

Averaged consecutive seven-day minimum discharge, in cubic feet per second, and indicated recurrence interval

2-year recurrence interval

0.90 10-year recurrence interval

0.00

Averaged consecutive seven-day minimum discharge, in cubic feet per second, and 10-year recurrence interval

\section{November-April}

0.49

\section{November-December}

0.47

\section{January-February}

29.4
March-April

74.4

Averaged consecutive seven-day minimum discharge, in cubic feet per second, and 10-year recurrence interval

$\begin{array}{cccccc}\text { November } & \text { December } & \text { January } & \text { February } & \text { March } & \text { April } \\ 0.46 & 21.5 & 30.6 & 60.6 & 93.2 & 96.3\end{array}$

\section{South Fork of Little Red River at Clinton, Ark.}

LOCATION.--Lat 35³5'12.77”, long 92 27’05.37” referenced to North American Datum of 1927, in SW 1/4 sec.14, T.11 N., R.14 W., Van Buren County, Ark., Hydrologic Unit 11010014, at U.S. Highway 65, 0.25 mi upstream from Archey Fork at Clinton.

DRAINAGE AREA.--148 square miles.

PERIOD OF RECORD.--October 1961 to September 1994, September 2001 to September 2005.

REMARKS.-- None.

Averaged consecutive seven-day minimum discharge, in cubic feet per second, and indicated recurrence interval

2-year recurrence interval

0.23 10-year recurrence interval

0.00

Averaged consecutive seven-day minimum discharge, in cubic feet per second, and 10-year recurrence interval

\section{November-April}

1.43
November-December

1.39
January-February

22.5
March-April

51.6

Averaged consecutive seven-day minimum discharge, in cubic feet per second, and 10-year recurrence interval

$\begin{array}{cccccc}\text { November } & \text { December } & \text { January } & \text { February } & \text { March } & \text { April } \\ 1.37 & 14.5 & 23.9 & 46.6 & 67.4 & 59.7\end{array}$


Table 4. Low-flow characteristics for continuous streamflow-record gaging stations having 10 or more years of streamflow record.-Continued

07075500 South Fork Little Red River near Clinton, Ark.

LOCATION.--Lat 35³4'00”, long 92²3'00”, Van Buren County, Hydrologic Unit 11010014, near Clinton.

DRAINAGE AREA.--316 square miles.

PERIOD OF RECORD.--March 1939 to December 1961.

REMARKS.-- None.

Averaged consecutive seven-day minimum discharge, in cubic feet per second, and indicated recurrence interval

2-year recurrence interval

0.58 10-year recurrence interval

0.00

Averaged consecutive seven-day minimum discharge, in cubic feet per second, and 10-year recurrence interval
November-April
November-December
January-February
March-April
0.01
0.01
24.4
90.9

Averaged consecutive seven-day minimum discharge, in cubic feet per second, and 10-year recurrence interval

$\begin{array}{cccccc}\text { November } & \text { December } & \text { January } & \text { February } & \text { March } & \text { April } \\ 0.01 & 7.89 & 25.9 & 73.1 & 107 & 143\end{array}$

07076000 Little Red River near Heber Springs, Ark.

LOCATION.--Lat 35³1'02”, long 9159'50” in NE 1/4 sec.7, T.10 N., R.9 W., Cleburne County, Hydrologic Unit 11010014, on right bank 1,600 ft downstream from Greers Ferry Dam, 3.0 mi northeast of Heber Springs, and at mile 78.8.

DRAINAGE AREA.--1,153 square miles.

PERIOD OF RECORD.--August 1964 to September 1980.

REMARKS.-- Highly regulated (highly altered).

Averaged consecutive seven-day minimum discharge, in cubic feet per second, and indicated recurrence interval

2-year recurrence interval

105 10-year recurrence interval

47.6

Averaged consecutive seven-day minimum discharge, in cubic feet per second, and 10-year recurrence interval

$\begin{array}{cccc}\text { November-April } & \text { November-December } & \text { January-February } & \text { March-April } \\ 50.3 & 60.2 & 100 & 91.8\end{array}$

Averaged consecutive seven-day minimum discharge, in cubic feet per second, and 10-year recurrence interval

$\begin{array}{cccccc}\text { November } & \text { December } & \text { January } & \text { February } & \text { March } & \text { April } \\ 80.4 & 84.5 & 182 & 124 & 153 & 124\end{array}$


Table 4. Low-flow characteristics for continuous streamflow-record gaging stations having 10 or more years of streamflow record.-Continued

07076620 Little Red River near Searcy, Ark.

LOCATION.--Lat $35^{\circ} 16^{\prime} 57^{\prime \prime}$, long 91 ${ }^{\circ} 43^{\prime} 09^{\prime \prime}$ in NE 1/4 NE 1/4 sec.35, T.8 N., R.7 W., White County, Hydrologic Unit 11010014, on right bank 0.8 mi upstream from lower dam, and 1.0 mi upstream from old Highway 67 bridge, 2.0 mi north of Searcy, and at mile 31.7.

DRAINAGE AREA.--1,648 square miles.

PERIOD OF RECORD.--June 1983 to September 1996.

REMARKS.-- Highly regulated (highly altered).

Averaged consecutive seven-day minimum discharge, in cubic feet per second, and indicated recurrence interval

2-year recurrence interval

145 10-year recurrence interval

2.65

Averaged consecutive seven-day minimum discharge, in cubic feet per second, and 10-year recurrence interval

$\begin{array}{cccc}\text { November-April } & \text { November-December } & \text { January-February } & \text { March-April } \\ 25.3 & 25.8 & 161 & 473\end{array}$

Averaged consecutive seven-day minimum discharge, in cubic feet per second, and 10-year recurrence interval

$\begin{array}{cccccc}\text { November } & \text { December } & \text { January } & \text { February } & \text { March } & \text { April } \\ 30.3 & 86.3 & 179 & 342 & 814 & 512\end{array}$

07076850 Cypress Bayou near Beebe, Ark.

LOCATION.--Lat 3501'30”, long 9152'23”, in SW 1/4 sec. 28, T.5 N., R.8 W., White-Lonoke County line, Hydrologic Unit 08020301, at bridge on State Highway 31, 3.0 mi south of Beebe.

DRAINAGE AREA.--166 square miles.

PERIOD OF RECORD.--October 1961 to September 1976.

REMARKS.-- None.

Averaged consecutive seven-day minimum discharge, in cubic feet per second, and indicated recurrence interval

2-year recurrence interval

0.00 10-year recurrence interval

0.00

Averaged consecutive seven-day minimum discharge, in cubic feet per second, and 10-year recurrence interval

$\begin{array}{cccc}\text { November-April } & \text { November-December } & \text { January-February } & \text { March-April } \\ 0.00 & 0.00 & 12.8 & 7.51\end{array}$

Averaged consecutive seven-day minimum discharge, in cubic feet per second, and 10-year recurrence interval

$\begin{array}{ccccccc}\text { November } & \text { December } & \text { January } & \text { February } & \text { March } & \text { April } \\ 0.00 & 1.17 & 14.0 & 27.1 & 30.4 & 7.34\end{array}$


Table 4. Low-flow characteristics for continuous streamflow-record gaging stations having 10 or more years of streamflow record.-Continued

07077000 White River at DeValls Bluff, Ark.

LOCATION.--Lat 3447’25”, long 91²6’45” referenced to North American Datum of 1927, in SE 1/4 sec.17, T.2 N., R.4 W., Prairie County, Ark., Hydrologic Unit 08020301, near center of span on downstream side of bridge on U.S. Highway 70, 1.0 mi northeast of DeValls Bluff, 7.5 mi downstream from Wattensaw Bayou, 24.1 mi upstream from Cache River, and at mile 125.3.

DRAINAGE AREA.--23,431 square miles.

PERIOD OF RECORD.--January 1964 to September 1970 and October 1988 to September 2005.

REMARKS.-- Highly regulated (highly altered).

Averaged consecutive seven-day minimum discharge, in cubic feet per second, and indicated recurrence interval

2-year recurrence interval

7,130 10-year recurrence interval

4,960

Averaged consecutive seven-day minimum discharge, in cubic feet per second, and 10-year recurrence interval

$\begin{array}{cccc}\text { November-April } & \text { November-December } & \text { January-February } & \text { March-April } \\ 4,960 & 4,940 & 7,450 & 10,500\end{array}$

Averaged consecutive seven-day minimum discharge, in cubic feet per second, and 10-year recurrence interval

$\begin{array}{cccccc}\text { November } & \text { December } & \text { January } & \text { February } & \text { March } & \text { April } \\ 5,200 & 6,190 & 7,820 & 10,300 & 12,800 & 13,000\end{array}$

\section{Cache River at Egypt, Ark.}

LOCATION.--Lat 3551'28”, long 9056’00”' referenced to North American Datum of 1927, in NW 1/4 SE 1/4 sec.12, T.14 N., R.1 E., Craighead County, Ark., Hydrologic Unit 08020302, on left upstream abutment of bridge on State Highway 91, $50 \mathrm{ft}$ downstream from junction of East Cache River Ditch (Cache River channel separation), 1.0 mi southeast of Egypt, 2.2 mi northwest of Winesburg, and at mile 143.

DRAINAGE AREA.--701 square miles.

PERIOD OF RECORD.--October 1964 to September 2005.

REMARKS.-- Numerous anthropogenic alterations within basin (highly altered).

Averaged consecutive seven-day minimum discharge, in cubic feet per second, and indicated recurrence interval

2-year recurrence interval 10-year recurrence interval

0.00

Averaged consecutive seven-day minimum discharge, in cubic feet per second, and 10-year recurrence interval
November-April
November-December
January-February
March-April
0.00
0.00
0.00
0.00

Averaged consecutive seven-day minimum discharge, in cubic feet per second, and 10-year recurrence interval

$\begin{array}{cccccc}\text { November } & \text { December } & \text { January } & \text { February } & \text { March } & \text { April } \\ 0.00 & 0.00 & 0.00 & 0.00 & 0.00 & 0.00\end{array}$


Table 4. Low-flow characteristics for continuous streamflow-record gaging stations having 10 or more years of streamflow record.-Continued

07077500 Cache River at Patterson, Ark.

LOCATION.--Lat 35¹6'10”, long 91 $14^{\prime}$ '15” referenced to North American Datum of 1927, in SE 1/4 sec.31, T.8 N., R.2 W., Woodruff County, Ark., Hydrologic Unit 08020302, at bridge on U.S. Highway 64 at Patterson, 10.9 mi upstream from Maple Slough, and at mile 77.2 .

DRAINAGE AREA.--1,037 square miles.

PERIOD OF RECORD.--October 1927 to September 1931, October 1937 to September 1977, and October 1997 to September 2005.

REMARKS.-- Numerous anthropogenic alterations within basin (highly altered).

Averaged consecutive seven-day minimum discharge, in cubic feet per second, and indicated recurrence interval

\section{2-year recurrence interval}

48.9

\section{0-year recurrence interval}

9.91

Averaged consecutive seven-day minimum discharge, in cubic feet per second, and 10-year recurrence interval

\section{November-April}

15.4
November-December

15.0
January-February

63.0
March-April

96.3

Averaged consecutive seven-day minimum discharge, in cubic feet per second, and 10-year recurrence interval November

14.8

\section{December}

41.6

\section{January}

73.5
February

116
March

195
April

114

\section{Cache River near Cotton Plant, Ark.}

LOCATION.--Lat 3502'07”, long 91¹9'19”' referenced to North American Datum of 1927, in SE 1/4 SW 1/4 sec.21, T.5 N., R.3 W., Woodruff County, Ark., Hydrologic Unit 08020302, on left bank on downstream side of bridge on county road, 1.4 mi upstream from Roaring Slough, and 4.2 mi northwest of Cotton Plant.

DRAINAGE AREA.--1,172 square miles.

PERIOD OF RECORD.--April 1987 to Sepember 2005.

REMARKS.-- Numerous anthropogenic alterations within basin (highly altered).

Averaged consecutive seven-day minimum discharge, in cubic feet per second, and indicated recurrence interval

2-year recurrence interval

46.8 10-year recurrence interval

15.6

Averaged consecutive seven-day minimum discharge, in cubic feet per second, and 10-year recurrence interval
November-April
November-December
17.0
January-February
March-April
19.4
151
133

Averaged consecutive seven-day minimum discharge, in cubic feet per second, and 10-year recurrence interval

$\begin{array}{cccccc}\text { November } & \text { December } & \text { January } & \text { February } & \text { March } & \text { April } \\ 18.2 & 57.6 & 249 & 252 & 247 & 156\end{array}$


Table 4. Low-flow characteristics for continuous streamflow-record gaging stations having 10 or more years of streamflow record.-Continued

07077700 Bayou DeView near Morton, Ark.

LOCATION.--Lat $35^{\circ} 15^{\prime} 07^{\prime \prime}$, long 9106'37' referenced to North American Datum of 1927, in sec.5, T.7 N., R.1 W., Woodruff County, Ark., Hydrologic Unit 08020302, at bridge on U.S. Highway 64, 1.0 mi west of Morton, and at mile 39.6.

DRAINAGE AREA.--421 square miles.

PERIOD OF RECORD.--April 1939 to May 1973, October 1973 to September 1977, and October 1997 to September 2005.

REMARKS.-- Numerous anthropogenic alterations within basin (highly altered).

Averaged consecutive seven-day minimum discharge, in cubic feet per second, and indicated recurrence interval

2-year recurrence interval

0.00 10-year recurrence interval

0.00

Averaged consecutive seven-day minimum discharge, in cubic feet per second, and 10-year recurrence interval
November-April
November-December
January-February
0.00
March-April
1.57
0.00
0.00

Averaged consecutive seven-day minimum discharge, in cubic feet per second, and 10-year recurrence interval

$\begin{array}{cccccc}\text { November } & \text { December } & \text { January } & \text { February } & \text { March } & \text { April } \\ 0.00 & 0.00 & 0.00 & 24.1 & 27.8 & 2.00\end{array}$

07077800 White River at Clarendon, Ark.

LOCATION.--Lat $34^{\circ} 41^{\prime} 08^{\prime \prime}$, long $91^{\circ} 18^{\prime} 55^{\prime}$ ' in W 1/4 sec.22, T.1 N., R.3 W., Monroe County, Hydrologic Unit 08020303, at St. Louis Southwestern Railroad bridge at Clarendon, $1.1 \mathrm{mi}$ downstream from Cache River and at mile 100.1.

DRAINAGE AREA.--25,555 square miles.

PERIOD OF RECORD.--January 1964 to September 1981.

REMARKS.-- Highly regulated (highly altered).

Averaged consecutive seven-day minimum discharge, in cubic feet per second, and indicated recurrence interval

2-year recurrence interval

8,700 10-year recurrence interval

6,100

Averaged consecutive seven-day minimum discharge, in cubic feet per second, and 10-year recurrence interval
November-April
November-December
January-February
March-April
6.280
6,530
7,590
10,600

Averaged consecutive seven-day minimum discharge, in cubic feet per second, and 10-year recurrence interval

$\begin{array}{cccccc}\text { November } & \text { December } & \text { January } & \text { February } & \text { March } & \text { April } \\ 6,540 & 8,030 & 8,000 & 9,040 & 12,500 & 13,000\end{array}$


Table 4. Low-flow characteristics for continuous streamflow-record gaging stations having 10 or more years of streamflow record.-Continued

07077930 Big Creek near Moro, Ark.

LOCATION.--Lat $34^{\circ} 50^{\prime} 50^{\prime \prime}$, long 91 $01^{\prime} 35^{\prime \prime}$ in NW 1/4 sec.28, T.3 N., R.1 E., Lee County, Hydrologic Unit 08020304, at bridge on State Highway 78, 3.5 mi north of Moro.

DRAINAGE AREA.--77.4 square miles.

PERIOD OF RECORD.--November 1961 to September 1970.

REMARKS.-- Numerous anthropogenic alterations within basin (highly altered).

Averaged consecutive seven-day minimum discharge, in cubic feet per second, and indicated recurrence interval

2-year recurrence interval

0.13 10-year recurrence interval

0.00

Averaged consecutive seven-day minimum discharge, in cubic feet per second, and 10-year recurrence interval

$\begin{array}{cccc}\text { November-April } & \text { November-December } & \text { January-February } & \text { March-April } \\ 0.00 & 0.00 & 2.24 & 0.66\end{array}$

Averaged consecutive seven-day minimum discharge, in cubic feet per second, and 10-year recurrence interval

$\begin{array}{cccccc}\text { November } & \text { December } & \text { January } & \text { February } & \text { March } & \text { April } \\ 0.00 & 0.00 & 2.06 & 6.97 & 1.46 & 0.66\end{array}$

07077950 Big Creek at Poplar Grove, Ark.

LOCATION.--Lat 34³3'20”, long 9050'44” in NE 1/4 NE 1/4 sec.1, T.2 S., R.2 E., Phillips County, Hydrologic Unit 08020304, near right bank on downstream side of bridge on U.S. Highway 49, at Poplar Grove, $900 \mathrm{ft}$ upstream from Crooked Creek, and 3.9 mi east of Marvel.

DRAINAGE AREA.--448 square miles, includes that of Crooked Creek. Area at site used prior to September 30, 1972, 459 square miles .

PERIOD OF RECORD.--October 1970 to September 1993.

REMARKS.-- Numerous anthropogenic alterations within basin (highly altered).

Averaged consecutive seven-day minimum discharge, in cubic feet per second, and indicated recurrence interval

2-year recurrence interval

2.81 10-year recurrence interval

0.00

Averaged consecutive seven-day minimum discharge, in cubic feet per second, and 10-year recurrence interval
November-April
November-December
January-February
March-April
2.02
1.92
39.1
32.4

Averaged consecutive seven-day minimum discharge, in cubic feet per second, and 10-year recurrence interval

$\begin{array}{cccccc}\text { November } & \text { December } & \text { January } & \text { February } & \text { March } & \text { April } \\ 2.09 & 21.6 & 46.7 & 118 & 70.5 & 39.1\end{array}$


Table 4. Low-flow characteristics for continuous streamflow-record gaging stations having 10 or more years of streamflow record.-Continued

\section{LaGrue Bayou near Stuttgart, Ark.}

LOCATION.--Lat 34³1'55”, long 91²1’21” in NW 1/4 NW 1/4 sec.17, T.2 S., R.3 W., Arkansas County, Hydrologic Unit 08020303, at bridge on State Highway 146, 9.8 mi east of Stuttgart.

DRAINAGE AREA.--176 square miles.

PERIOD OF RECORD.--October 1935 to September 1954.

REMARKS.-- Numerous anthropogenic alterations within basin (highly altered).

Averaged consecutive seven-day minimum discharge, in cubic feet per second, and indicated recurrence interval

2-year recurrence interval

0.08 10-year recurrence interval

0.00

Averaged consecutive seven-day minimum discharge, in cubic feet per second, and 10-year recurrence interval

$\begin{array}{cccc}\text { November-April } & \text { November-December } & \text { January-February } & \text { March-April } \\ 0.00 & 0.00 & 5.18 & 4.33\end{array}$

Averaged consecutive seven-day minimum discharge, in cubic feet per second, and 10-year recurrence interval

$\begin{array}{cccccc}\text { November } & \text { December } & \text { January } & \text { February } & \text { March } & \text { April } \\ 0.00 & 0.94 & 6.63 & 11.8 & 11.3 & 4.36\end{array}$

07194800 Illinois River at Savoy, Ark.

LOCATION.--Lat 3606'11”, long 94²0'40” referenced to North American Datum of 1927, SES36T17NR32W, Washington County, Ark., Hydrologic Unit 11110103, on eastern boundary of Ozark National Forest, on left bank downstream end of State Highway 16 bridge, 0.3 mi downstream from tributary of Lake Weddington, 0.4 mi upstream from Clear Creek, and 0.9 mi southwest of Savoy.

DRAINAGE AREA.--167 square miles.

PERIOD OF RECORD.--July 1979 to December 1981, September 1985 to September 1986, September 1995 to September 2005.

REMARKS.-- None.

Averaged consecutive seven-day minimum discharge, in cubic feet per second, and indicated recurrence interval

2-year recurrence interval

8.26 10-year recurrence interval

3.65

Averaged consecutive seven-day minimum discharge, in cubic feet per second, and 10-year recurrence interval
November-April
November-December
January-February
March-April
8.21
8.94
11.3
15.4

Averaged consecutive seven-day minimum discharge, in cubic feet per second, and 10-year recurrence interval

$\begin{array}{cccccc}\text { November } & \text { December } & \text { January } & \text { February } & \text { March } & \text { April } \\ 9.80 & 10.5 & 12.2 & 14.2 & 17.8 & 20.5\end{array}$


Table 4. Low-flow characteristics for continuous streamflow-record gaging stations having 10 or more years of streamflow record.-Continued

07195000 Osage Creek near Elm Springs, Ark.

LOCATION.--Lat 36 13'19”, long 9417'18”' referenced to North American Datum of 1927, in SW 1/4 NE 1/4 sec.21, T.18 N., R.31 W., Benton County, Hydrologic Unit 11110103, on left bank 0.7 mi downstream from Little Osage Creek, and 3.2 mi. northwest of Elm Springs.

DRAINAGE AREA.--130 square miles.

PERIOD OF RECORD.--October 1950 to September 1975, and August 1995 to September 2005.

REMARKS. Numerous anthropogenic alterations within basin (highly altered).

Averaged consecutive seven-day minimum discharge, in cubic feet per second, and indicated recurrence interval

2-year recurrence interval

38.0 10-year recurrence interval

16.0

Averaged consecutive seven-day minimum discharge, in cubic feet per second, and 10-year recurrence interval

$\begin{array}{cccc}\text { November-April } & \text { November-December } & \text { January-February } & \text { March-April } \\ 21.9 & 23.1 & 25.7 & 32.4\end{array}$

Averaged consecutive seven-day minimum discharge, in cubic feet per second, and 10-year recurrence interval

$\begin{array}{cccccc}\text { November } & \text { December } & \text { January } & \text { February } & \text { March } & \text { April } \\ 23.6 & 24.4 & 26.1 & 30.9 & 33.6 & 37.0\end{array}$

07195430 Illinois River South of Siloam Springs, Ark.

LOCATION.--Lat 3606’31”, long 94³2’00”' referenced to North American Datum of 1983, in SE 1/4 NE 1/4 sec.31, T.17 N., R.33 W., Benton County, Ark., Hydrologic Unit 11110103, at bridge on State Highway 59, 5.0 mi south of Siloam Springs, and 0.6 mi downstream from mouth of Cincinnati Creek.

DRAINAGE AREA.--575 square miles.

PERIOD OF RECORD.--August 1995 to September 2005.

REMARKS.-- None.

Averaged consecutive seven-day minimum discharge, in cubic feet per second, and indicated recurrence interval

2-year recurrence interval

122 10-year recurrence interval

95.1

Averaged consecutive seven-day minimum discharge, in cubic feet per second, and 10-year recurrence interval

\section{November-April}

127

\section{November-December}

124
January-February

165
March-April

186

Averaged consecutive seven-day minimum discharge, in cubic feet per second, and 10-year recurrence interval November

122

\section{December}

170
January

169
February

183
March

208
April 
Table 4. Low-flow characteristics for continuous streamflow-record gaging stations having 10 or more years of streamflow record.-Continued

07195800 Flint Creek at Springtown, Ark.

LOCATION.--Lat $36^{\circ} 15^{\prime} 21.50^{\prime \prime}$, long 94²6’00.80” referenced to North American Datum of 1983, in NW 1/4 sec.7, T.13 N., R.32 W., Benton County, Ark., Hydrologic Unit 11110103, on right bank $20 \mathrm{ft}$ downstream from State Highway 12, 0.8 mi southwest of Springtown.

DRAINAGE AREA.--14.2 square miles.

PERIOD OF RECORD.--July 1961 to September 2005.

REMARKS.-- None.

Averaged consecutive seven-day minimum discharge, in cubic feet per second, and indicated recurrence interval

2-year recurrence interval

3.40 10-year recurrence interval

1.19

Averaged consecutive seven-day minimum discharge, in cubic feet per second, and 10-year recurrence interval

$\begin{array}{cccc}\text { November-April } & \text { November-December } & \text { January-February } & \text { March-April } \\ 2.44 & 2.77 & 3.49 & 3.94\end{array}$

Averaged consecutive seven-day minimum discharge, in cubic feet per second, and 10-year recurrence interval

$\begin{array}{cccccc}\text { November } & \text { December } & \text { January } & \text { February } & \text { March } & \text { April } \\ 2.75 & 3.74 & 3.68 & 4.05 & 4.14 & 4.62\end{array}$

\section{Flint Creek near West Siloam Springs, Ark.}

LOCATION.--Lat 36² 12'58”, long 94³6'15” referenced to North American Datum of 1927, in NE 1/4 NE 1/4 sec.14, T.20 N., R.25 E., Delaware County, Hydrologic Unit 11110103, on left bank $800 \mathrm{ft}$ downstream from county bridge, 2.5 mi from Arkansas-Oklahoma State line, northwest of West Siloam Springs, Okla.,

DRAINAGE AREA.--59.8 square miles.

PERIOD OF RECORD.--October 1979 to September 2005.

REMARKS.-- Numerous anthropogenic alterations within basin (highly altered).

Averaged consecutive seven-day minimum discharge, in cubic feet per second, and indicated recurrence interval

2-year recurrence interval

6.67 10-year recurrence interval

1.62

Averaged consecutive seven-day minimum discharge, in cubic feet per second, and 10-year recurrence interval

$\begin{array}{cccc}\text { November-April } & \text { November-December } & \text { January-February } & \text { March-April } \\ 5.48 & 6.43 & 7.04 & 8.94\end{array}$

Averaged consecutive seven-day minimum discharge, in cubic feet per second, and 10-year recurrence interval

$\begin{array}{cccccc}\text { November } & \text { December } & \text { January } & \text { February } & \text { March } & \text { April } \\ 6.49 & 8.36 & 7.06 & 8.41 & 9.65 & 12.9\end{array}$


Table 4. Low-flow characteristics for continuous streamflow-record gaging stations having 10 or more years of streamflow record.-Continued

07196900 Baron Fork at Dutch Mills, Ark.

LOCATION.--Lat 3552’48”, long 94²9’11” referenced to North American Datum of 1927, Washington County, Ark., Hydrologic Unit 11110103, near right bank on downstream side of bridge on State Highway 59 at Dutch Mills, 2.2 mi downstream from Fly Creek, and 2.9 mi upstream from Arkansas-Oklahoma State line.

DRAINAGE AREA.--40.6 square miles.

PERIOD OF RECORD.--April 1958 to September 2005.

REMARKS.-- None.

Averaged consecutive seven-day minimum discharge, in cubic feet per second, and indicated recurrence interval

\section{2-year recurrence interval}

0.60

\section{0-year recurrence interval}

0.01

Averaged consecutive seven-day minimum discharge, in cubic feet per second, and 10-year recurrence interval

\section{November-April}

0.77

\section{November-December}

0.76
January-February

2.10
March-April

4.62

Averaged consecutive seven-day minimum discharge, in cubic feet per second, and 10-year recurrence interval

November

0.77
December

1.67
January

2.19
February

4.09
March

5.73
April

6.08

07247000 Poteau River at Cauthron, Ark.

LOCATION.--Lat 3455'08”, long 94¹7'58”' referenced to North American Datum of 1927, in NW 1/4 SE 1/4 sec.16, T.3 N., R.31 W., Scott County, Ark., Hydrologic Unit 11110105, on right bank at downstream side of Scott County Road No. 56 bridge at Cauthron, $200 \mathrm{ft}$ south of juncton with State Hwy 28, 2.9 mi downstream from Cross Creek, 7.8 mi downstream from Jones Creek, and at mile 109.0.

DRAINAGE AREA.--203 square miles.

PERIOD OF RECORD.--March 1939 to September 2005.

REMARKS.-- None.

Averaged consecutive seven-day minimum discharge, in cubic feet per second, and indicated recurrence interval

2-year recurrence interval

0.32

\section{0-year recurrence interval}

0.00

Averaged consecutive seven-day minimum discharge, in cubic feet per second, and 10-year recurrence interval

\section{November-April}

0.06

\section{November-December}

0.06

\section{January-February}

3.93
March-April

13.0

Averaged consecutive seven-day minimum discharge, in cubic feet per second, and 10-year recurrence interval

November

0.07
December

2.38
January

4.04

\section{February}

15.0
March

19.3
April

15.7 
Table 4. Low-flow characteristics for continuous streamflow-record gaging stations having 10 or more years of streamflow record.-Continued

07249400 James Fork near Hackett, Ark.

LOCATION.--Lat 3509'45”, long 94²4'25” referenced to North American Datum of 1927, in NW 1/4 NW 1/4 sec.34, T.6 N., R.32 W., Sebastian County, Ark., Hydrologic Unit 11110105, near left bank on downstream side of bridge on State Highway 45, 1.7 mi south of Hackett, 2.0 mi downstream from Elder Branch, 2.0 mi upstream from small tributary, and 3.6 mi upstream from Arkansas-Oklahoma State line.

DRAINAGE AREA.--147 square miles.

PERIOD OF RECORD.--April 1958 to September 2005.

REMARKS.-- None.

Averaged consecutive seven-day minimum discharge, in cubic feet per second, and indicated recurrence interval

2-year recurrence interval

0.84
10 -year recurrence interval

0.00

Averaged consecutive seven-day minimum discharge, in cubic feet per second, and 10-year recurrence interval November-April

0.87
November-December

$$
0.90
$$

January-February

2.49
March-April

7.98

Averaged consecutive seven-day minimum discharge, in cubic feet per second, and 10-year recurrence interval

$\begin{array}{cccccc}\text { November } & \text { December } & \text { January } & \text { February } & \text { March } & \text { April } \\ 0.91 & 2.21 & 2.73 & 7.44 & 12.0 & 11.6\end{array}$

\section{Cove Creek near Lee Creek, Ark.}

LOCATION.--Lat 3541'10”, long 94²2'00”, in SE 1/4 SW 1/4 sec. 26, T.12 N., R.32 W., Crawford County, Hydrologic Unit 11010104, at low-water crossing on unimproved road, $0.7 \mathrm{mi}$ upstream from Lee Creek, and 1.0 mi west of Lee Creek.

DRAINAGE AREA.--35.3 square miles.

PERIOD OF RECORD.--May 1950 to September 1970.

REMARKS.-- None.

Averaged consecutive seven-day minimum discharge, in cubic feet per second, and indicated recurrence interval

2-year recurrence interval

0.08

\section{0-year recurrence interval}

0.00

Averaged consecutive seven-day minimum discharge, in cubic feet per second, and 10-year recurrence interval

\section{November-April}

0.00

\section{November-December}

0.00

\section{January-February}

0.65
March-April

3.02

Averaged consecutive seven-day minimum discharge, in cubic feet per second, and 10-year recurrence interval

\section{November}

0.00

\section{December}

0.27

\section{January}

0.64
February

2.90
March

3.44
April

5.70 
Table 4. Low-flow characteristics for continuous streamflow-record gaging stations having 10 or more years of streamflow record.-Continued

07249985 Lee Creek near Short, Okla.

LOCATION.--Lat 35'33'57', long 94³1'56" referenced to North American Datum of 1927, in SE 1/4 sec.27, T.13 N., R.26 E., Sequoyah County, Okla., Hydrologic Unit 11110104, on right bank at right downstream end of bridge on State Hwy 101, 0.5 mi west of Short, Okla.

DRAINAGE AREA.--236 square miles.

PERIOD OF RECORD.--October 1930 to June 1937, October 1950 to September 2005.

REMARKS.-- None.

Averaged consecutive seven-day minimum discharge, in cubic feet per second, and indicated recurrence interval

2-year recurrence interval

0.66 10-year recurrence interval

0.00

Averaged consecutive seven-day minimum discharge, in cubic feet per second, and 10-year recurrence interval
November-April
November-December
January-February
March-April
0.18
0.17
15.3
63.1

Averaged consecutive seven-day minimum discharge, in cubic feet per second, and 10-year recurrence interval

$\begin{array}{cccccc}\text { November } & \text { December } & \text { January } & \text { February } & \text { March } & \text { April } \\ 0.17 & 7.09 & 15.8 & 49.4 & 76.6 & 101\end{array}$

07250085 Lee Creek at Lee Creek Reservoir near Van Buren, Ark.

LOCATION.--Lat 35'29'02", long 94²3'34" referenced to North American Datum of 1927, SESW S03 T 09N R 32W5, Crawford County, Ark., Hydrologic Unit 11110104, in control house at dam on left bank, 2.8 mi northwest of Van Buren, and at mile 3.5.

DRAINAGE AREA.--432 square miles.

PERIOD OF RECORD.--October 1992 to September 2005.

REMARKS.-- Highly regulated (highly altered).

Averaged consecutive seven-day minimum discharge, in cubic feet per second, and indicated recurrence interval

2-year recurrence interval

0.00

\section{0-year recurrence interval}

0.00

Averaged consecutive seven-day minimum discharge, in cubic feet per second, and 10-year recurrence interval

\section{November-April}

0.00
November-December

0.00
January-February

0.00
March-April

0.00

Averaged consecutive seven-day minimum discharge, in cubic feet per second, and 10-year recurrence interval

\section{November}

0.00

\section{December}

0.00

\section{January}

0.00

\section{February}

0.00
March

0.00
April

0.00 
Table 4. Low-flow characteristics for continuous streamflow-record gaging stations having 10 or more years of streamflow record.-Continued

07250550 Arkansas River at James W. Trimble L\&D near Van Buren, Ark.

LOCATION.--Lat 35²0'56”, long 94¹7'54” referenced to North American Datum of 1927, in sec.28, T.8 N., R.31 W., Sebastian County, Ark., Hydrologic Unit 11110104, in metal shelter on dam and at mile 308.9.

DRAINAGE AREA.--150,547 square miles, of which 22,241 square miles is probably noncontributing.

PERIOD OF RECORD.--April 1970 to September 2005.

REMARKS.-- Highly regulated (highly altered).

Averaged consecutive seven-day minimum discharge, in cubic feet per second, and indicated recurrence interval

2-year recurrence interval

2,250 10-year recurrence interval

878

Averaged consecutive seven-day minimum discharge, in cubic feet per second, and 10-year recurrence interval
November-April
November-December
January-February
March-April
1,180
1,200
2,520
4,100

Averaged consecutive seven-day minimum discharge, in cubic feet per second, and 10-year recurrence interval

$\begin{array}{cccccc}\text { November } & \text { December } & \text { January } & \text { February } & \text { March } & \text { April } \\ 1,470 & 2,100 & 2,730 & 3,840 & 5,760 & 5,320\end{array}$

07251000 Frog Bayou near Mountainburg, Ark.

LOCATION.--Lat 35³9'40”, long 9409’10” referenced to North American Datum of 1927, in NW 1/4 NE 1/4 sec. 2, T.11 N., R.30 W., Crawford County, Ark., Hydrologic Unit 11110201, on left bank above concrete weir in spillway of Fort Smith Dam 0.8 mi upstream from Warloop Creek, 1.2 mi upstream from Howard Fork, 2.5 mi northeast of Mountainburg, and 3 mi downstream from Jones Fork.

DRAINAGE AREA.--74.0 square miles.

PERIOD OF RECORD.--October 1936 to September 1961.

REMARKS.-- Numerous anthropogenic alterations within basin (highly altered).

Averaged consecutive seven-day minimum discharge, in cubic feet per second, and indicated recurrence interval

2-year recurrence interval

0.00 10-year recurrence interval

0.00

Averaged consecutive seven-day minimum discharge, in cubic feet per second, and 10-year recurrence interval November-April

0.00

November-December

0.00
January-February

0.00
March-April

2.22

Averaged consecutive seven-day minimum discharge, in cubic feet per second, and 10-year recurrence interval

$\begin{array}{cccccc}\text { November } & \text { December } & \text { January } & \text { February } & \text { March } & \text { April } \\ 0.00 & 0.00 & 0.00 & 0.00 & 2.23 & 11.5\end{array}$


Table 4. Low-flow characteristics for continuous streamflow-record gaging stations having 10 or more years of streamflow record.-Continued

07251500 Frog Bayou at Rudy, Ark.

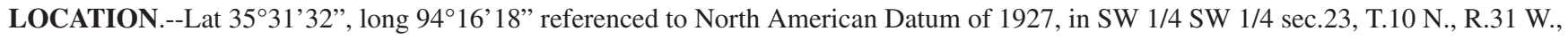
Crawford County, Ark., Hydrologic Unit 11110104, at bridge on State Highway 282 at Rudy.

DRAINAGE AREA.--216 square miles.

PERIOD OF RECORD.-May 1950 to September 1970 and October 2002 to September 2004.

REMARKS.-- Numrous anthropogenic alterations within basin (highly altered).

Averaged consecutive seven-day minimum discharge, in cubic feet per second, and indicated recurrence interval

2-year recurrence interval

1.01 10-year recurrence interval

0.00

Averaged consecutive seven-day minimum discharge, in cubic feet per second, and 10-year recurrence interval

$\begin{array}{cccc}\text { November-April } & \text { November-December } & \text { January-February } & \text { March-April } \\ 0.00 & 0.00 & 3.57 & 19.4\end{array}$

Averaged consecutive seven-day minimum discharge, in cubic feet per second, and 10-year recurrence interval

$\begin{array}{cccccc}\text { November } & \text { December } & \text { January } & \text { February } & \text { March } & \text { April } \\ 0.00 & 2.38 & 3.57 & 17.2 & 22.6 & 44.4\end{array}$

07252000 Mulberry River near Mulberry, Ark.

LOCATION.--Lat 35³4’38”, long 9400'56”' referenced to North American Datum of 1927, in SE 1/4 SW 1/4 sec.31, T.11 N., R.28 W., Franklin County, Ark., Hydrologic Unit 11110201, on left bank 0.6 mi upstream from Mill Creek, 5.7 mi north of Mulberry, and at mile 11.3.

DRAINAGE AREA.--373 square miles.

PERIOD OF RECORD.--June 1938 to January 1995, October 1998 to September 2005.

REMARKS.-- None.

Averaged consecutive seven-day minimum discharge, in cubic feet per second, and indicated recurrence interval

2-year recurrence interval

1.36 10-year recurrence interval

0.00

Averaged consecutive seven-day minimum discharge, in cubic feet per second, and 10-year recurrence interval
November-April
November-December
1.38
January-February
March-April
1.37
25.8
91.0

Averaged consecutive seven-day minimum discharge, in cubic feet per second, and 10-year recurrence interval

$\begin{array}{cccccc}\text { November } & \text { December } & \text { January } & \text { February } & \text { March } & \text { April } \\ 1.35 & 14.3 & 27.2 & 82.5 & 109 & 160\end{array}$


Table 4. Low-flow characteristics for continuous streamflow-record gaging stations having 10 or more years of streamflow record.-Continued

07253000 Sixmile Creek at Chismville, Ark.

LOCATION.--Lat 35¹3'15”, long 9356’20”, in E 1/2 sec. 2, T.6 N., R.28 W., Logan County, Hydrologic Unit 11110202, on right bank on downstream side of highway bridge at Chismville, 0.5 mi downstream from Rocky Creek, and at mile 25.6.

DRAINAGE AREA.--24.1 square miles.

PERIOD OF RECORD.--July 1954 to April 1970.

REMARKS.-- None.

Averaged consecutive seven-day minimum discharge, in cubic feet per second, and indicated recurrence interval

2-year recurrence interval

0.00 10-year recurrence interval

0.00

Averaged consecutive seven-day minimum discharge, in cubic feet per second, and 10-year recurrence interval

$\begin{array}{cccc}\text { November-April } & \text { November-December } & \text { January-February } & \text { March-April } \\ 0.00 & 0.00 & 0.00 & 0.37\end{array}$

Averaged consecutive seven-day minimum discharge, in cubic feet per second, and 10-year recurrence interval

$\begin{array}{cccccc}\text { November } & \text { December } & \text { January } & \text { February } & \text { March } & \text { April } \\ 0.00 & 0.00 & 0.00 & 0.18 & 0.53 & 0.57\end{array}$

07253500 Sixmile Creek near Branch, Ark.

LOCATION.--Lat 35¹4'55”, long 9358'28”, in NE 1/4 SE 1/4 sec. 28, T.7 N., R.28 W., Franklin County, Hydrologic Unit 11110202, 0.4 mi downstream from Rattlesnake Creek, 1.0 mi upstream from Prairie Creek, 4.2 mi southwest of Branch, and at mile 21.5.

DRAINAGE AREA.--36.7 square miles.

PERIOD OF RECORD.--July 1954 to April 1970.

REMARKS.-- None.

Averaged consecutive seven-day minimum discharge, in cubic feet per second, and indicated recurrence interval

2-year recurrence interval

0.00 10-year recurrence interval

0.00

Averaged consecutive seven-day minimum discharge, in cubic feet per second, and 10-year recurrence interval
November-April
November-December
January-February
0.00
March-April
0.00
1.31

Averaged consecutive seven-day minimum discharge, in cubic feet per second, and 10-year recurrence interval

$\begin{array}{cccccc}\text { November } & \text { December } & \text { January } & \text { February } & \text { March } & \text { April } \\ 0.00 & 0.00 & 0.00 & 0.60 & 1.86 & 1.56\end{array}$


Table 4. Low-flow characteristics for continuous streamflow-record gaging stations having 10 or more years of streamflow record.-Continued

07255000 Sixmile Creek at Caulksville, Ark.

LOCATION.--Lat 35'18'05”, long 93'51'15”, in SE 1/4 sec. 3, T.7 N., R.27 W., Logan County, Hydrologic Unit 11110202, at bridge on State Highway 22, 0.6 mi east of Caulksville.

DRAINAGE AREA.--104 square miles.

PERIOD OF RECORD.--July 1954 to April 1970.

REMARKS.-- None.

Averaged consecutive seven-day minimum discharge, in cubic feet per second, and indicated recurrence interval

2-year recurrence interval

0.01 10-year recurrence interval

0.00

Averaged consecutive seven-day minimum discharge, in cubic feet per second, and 10-year recurrence interval
November-April
November-December
January-February
March-April
0.00
0.00
0.00
4.30

Averaged consecutive seven-day minimum discharge, in cubic feet per second, and 10-year recurrence interval

$\begin{array}{cccccc}\text { November } & \text { December } & \text { January } & \text { February } & \text { March } & \text { April } \\ 0.00 & 0.00 & 0.00 & 0.88 & 6.10 & 1.90\end{array}$

07255500 Hurricane Creek near Branch, Ark.

LOCATION.--Lat $35^{\circ} 21^{\prime} 03^{\prime \prime}$, long 93 $56^{\prime} 02^{\prime}$, on line between and near south edge of secs. 23 and 24, T.8 N., R.28 W., Franklin County, Hydrologic Unit 11110202, at center of span on downstream side of bridge on State Highway 41, 1.5 mi upstream from Perry Creek, 3.2 mi northeast of Branch, and at mile 9.0

DRAINAGE AREA.--17.2 square miles.

PERIOD OF RECORD.--July 1954 to April 1970.

REMARKS.-- None.

Averaged consecutive seven-day minimum discharge, in cubic feet per second, and indicated recurrence interval

2-year recurrence interval

0.00 10-year recurrence interval

0.00

Averaged consecutive seven-day minimum discharge, in cubic feet per second, and 10-year recurrence interval
November-April
0.00
November-December
0.00
January-February
0.00
March-April
0.82

Averaged consecutive seven-day minimum discharge, in cubic feet per second, and 10-year recurrence interval

$\begin{array}{cccccc}\text { November } & \text { December } & \text { January } & \text { February } & \text { March } & \text { April } \\ 0.00 & 0.00 & 0.00 & 0.24 & 2.25 & 0.49\end{array}$


Table 4. Low-flow characteristics for continuous streamflow-record gaging stations having 10 or more years of streamflow record.-Continued

07256000 Hurricane Creek near Caulksville, Ark.

LOCATION.--Lat 35²0’49”, long 9351'44”, in SE 1/4 sec. 21, T.8 N., R.27 W., Franklin County, Hydrologic Unit 11110202, at bridge on State Highway 23, $3.2 \mathrm{mi}$ north of Caulksville.

DRAINAGE AREA.--53.0 square miles.

PERIOD OF RECORD.--July 1954 to April 1970.

REMARKS.-- None.

Averaged consecutive seven-day minimum discharge, in cubic feet per second, and indicated recurrence interval

2-year recurrence interval

0.00 10-year recurrence interval

0.00

Averaged consecutive seven-day minimum discharge, in cubic feet per second, and 10-year recurrence interval

$\begin{array}{cccc}\text { November-April } & \text { November-December } & \text { January-February } & \text { March-April } \\ 0.00 & 0.00 & 0.00 & 1.84\end{array}$

Averaged consecutive seven-day minimum discharge, in cubic feet per second, and 10-year recurrence interval

$\begin{array}{cccccc}\text { November } & \text { December } & \text { January } & \text { February } & \text { March } & \text { April } \\ 0.00 & 0.00 & 0.00 & 1.01 & 5.46 & 0.97\end{array}$

07256500 Spadra Creek at Clarksville, Ark.

LOCATION.--Lat 35²8'06”, long 93²7’46” in NW 1/4 NE 1/4 sec.5, T.9 N., R.23 W., Johnson County, Hydrologic Unit 11110202, on right bank at Clarksville, 0.2 mi downstream from bridge on U.S. Highway 64.

DRAINAGE AREA.--61.1 square miles.

PERIOD OF RECORD.--October 1952 to September 1970.

REMARKS.-- Numerous anthropogenic alterations within basin (highly altered).

Averaged consecutive seven-day minimum discharge, in cubic feet per second, and indicated recurrence interval

2-year recurrence interval

1.48 10-year recurrence interval

0.00

Averaged consecutive seven-day minimum discharge, in cubic feet per second, and 10-year recurrence interval
November-April
November-December
January-February
March-April
0.00
0.00
1.10
10.1

Averaged consecutive seven-day minimum discharge, in cubic feet per second, and 10-year recurrence interval

$\begin{array}{cccccc}\text { November } & \text { December } & \text { January } & \text { February } & \text { March } & \text { April } \\ 0.00 & 0.82 & 1.11 & 7.83 & 12.7 & 12.2\end{array}$


Table 4. Low-flow characteristics for continuous streamflow-record gaging stations having 10 or more years of streamflow record.-Continued

\section{Big Piney Creek at Highway 164 near Dover, Ark.}

LOCATION.--Lat 3530'20.8”, long 93¹0'53.2” referenced to North American Datum of 1983, in SE 1/4 NW 1/4 sec.25, T.10 N., R.21 W., Pope County, Ark., Hydrologic Unit 11110202, on right bank 11.9 mi downstream from Indian Creek, 7.2 mi north of Dover, and at mile 23 on State Highway 164 bridge.

DRAINAGE AREA.--297 square miles.

PERIOD OF RECORD.--October 1950 to September 1995, October 1998 to September 2005.

REMARKS.-- None.

Averaged consecutive seven-day minimum discharge, in cubic feet per second, and indicated recurrence interval

2-year recurrence interval

0.79 10-year recurrence interval

0.00

Averaged consecutive seven-day minimum discharge, in cubic feet per second, and 10-year recurrence interval

\section{November-April}

1.03

\section{November-December}

1.01

\section{January-February}

23.6
March-April

78.3

Averaged consecutive seven-day minimum discharge, in cubic feet per second, and 10-year recurrence interval

\section{November}

0.99

\section{December}

16.9
January

23.8
February

70.2
March

94.1
April

121

\section{Illinois Bayou near Scottsville, Ark.}

LOCATION.--Lat 35²7'59”, long 9302’28” referenced to North American Datum of 1927, in SE 1/4 SW 1/4 sec.31, T.10 N., R.19 W., Pope County, Ark., Hydrologic Unit 11110202, on downstream side of bridge on State Highway 164, 1.3 mi north of Scottsville, and 3.1 mi downstream from North Fork Illinois Bayou.

DRAINAGE AREA.--241 square miles.

PERIOD OF RECORD.--October 1947 to September 1970 , October 1999 to September 2005.

REMARKS.-- None.

Averaged consecutive seven-day minimum discharge, in cubic feet per second, and indicated recurrence interval

2-year recurrence interval

1.05

\section{0-year recurrence interval}

0.00

Averaged consecutive seven-day minimum discharge, in cubic feet per second, and 10-year recurrence interval

\section{November-April}

0.18

\section{November-December}

0.18

\section{January-February}

17.1
March-April

65.7

Averaged consecutive seven-day minimum discharge, in cubic feet per second, and 10-year recurrence interval

$\begin{array}{cccccc}\text { November } & \text { December } & \text { January } & \text { February } & \text { March } & \text { April } \\ 0.18 & 7.05 & 17.7 & 51.8 & 88.1 & 80.1\end{array}$


Table 4. Low-flow characteristics for continuous streamflow-record gaging stations having 10 or more years of streamflow record.-Continued

07258000 Arkansas River at Dardanelle, Ark.

LOCATION.--Lat 35'13'34”, long 9308'58” in SW1/4 sec.29, T.7 N., R.20 W., Pope County, Hydrologic Unit 11110203, near left bank on upstream side of bridge on State Highway 7 at Dardanelle, 1.0 mi upstream from Whig Creek, 2.0 mi downstream from Dardanelle Dam, 4.7 mi downstream from Illinois Bayou, and at mile 219.5.

DRAINAGE AREA.--153,670 square miles of which 22, 241 square miles are probably noncontributing.

PERIOD OF RECORD.--April 1970 to September 1994, October 2000 to September 2003.

REMARKS.-- Highly regulated (highly altered).

Averaged consecutive seven-day minimum discharge, in cubic feet per second, and indicated recurrence interval

2-year recurrence interval

1,980 10-year recurrence interval

743

Averaged consecutive seven-day minimum discharge, in cubic feet per second, and 10-year recurrence interval

\section{November-April}

1,210

\section{November-December}

1,200
January-February

2,950
March-April

5,480

Averaged consecutive seven-day minimum discharge, in cubic feet per second, and 10-year recurrence interval

$\begin{array}{cccccc}\text { November } & \text { December } & \text { January } & \text { February } & \text { March } & \text { April } \\ 1,480 & 2,020 & 3,030 & 4,410 & 7,680 & 6,550\end{array}$

07258500 Petit Jean River near Booneville, Ark.

LOCATION.--Lat 3506'25”, long 9355’25” referenced to North American Datum of 1927, in NW 1/4 NW 1/4 sec.18, T.5 N., R.27 W., Logan County, Ark., Hydrologic Unit 11110204, on right bank at downstream side of bridge on State Highway 23, 0.5 mi downstream from Fletcher Creek, 2.3 mi south of Booneville.

DRAINAGE AREA.--241 square miles.

PERIOD OF RECORD.--November 1938 to September 1984, October 1999 to September 2005.

REMARKS.-- None.

Averaged consecutive seven-day minimum discharge, in cubic feet per second, and indicated recurrence interval

2-year recurrence interval

0.04 10-year recurrence interval

0.00

Averaged consecutive seven-day minimum discharge, in cubic feet per second, and 10-year recurrence interval
November-April
November-December
0.00
January-February
March-April
0.00
1.60
14.5

Averaged consecutive seven-day minimum discharge, in cubic feet per second, and 10-year recurrence interval

$\begin{array}{cccccc}\text { November } & \text { December } & \text { January } & \text { February } & \text { March } & \text { April } \\ 0.00 & 0.44 & 1.67 & 9.22 & 21.1 & 19.3\end{array}$


Table 4. Low-flow characteristics for continuous streamflow-record gaging stations having 10 or more years of streamflow record.-Continued

07259500 Petit Jean River near Waveland, Ark.

LOCATION.--Lat 3506'17”, long 93³7'53" in SE 1/4 SE 1/4 sec.11, T.5 N., R.25 W., Yell County, Ark., Hydrologic Unit 11110204, at Blue Mountain Dam, 1.9 mi southwest of Waveland, and at mile 74.4.

DRAINAGE AREA.--516 square miles.

PERIOD OF RECORD.--February 1939 to September 1980.

REMARKS.-- Highly regulated (highly altered).

Averaged consecutive seven-day minimum discharge, in cubic feet per second, and indicated recurrence interval

2-year recurrence interval

4.95 10-year recurrence interval

0.34

Averaged consecutive seven-day minimum discharge, in cubic feet per second, and 10-year recurrence interval

$\begin{array}{cccc}\text { November-April } & \text { November-December } & \text { January-February } & \text { March-April } \\ 1.08 & 1.05 & 6.32 & 16.2\end{array}$

Averaged consecutive seven-day minimum discharge, in cubic feet per second, and 10-year recurrence interval

$\begin{array}{cccccc}\text { November } & \text { December } & \text { January } & \text { February } & \text { March } & \text { April } \\ 1.10 & 3.65 & 7.27 & 15.1 & 22.2 & 22.0\end{array}$

\section{Dutch Creek at Waltreak, Ark.}

LOCATION.--Lat 3453'13.3”, long 93³6’47.1” referenced to North American Datum of 1927, in SE 1/4 NW 1/4 sec.24, T.4 N., R.25 W., Yell County, Ark., Hydrologic Unit 11110204, on left bank 0.2 mi north of Waltreak and 21.0 mi upstream from mouth.

DRAINAGE AREA.--81.4 square miles.

PERIOD OF RECORD.--October 1945 to November 1975, October 1999 to September 2005.

REMARKS.-- None.

Averaged consecutive seven-day minimum discharge, in cubic feet per second, and indicated recurrence interval

2-year recurrence interval

0.00 10-year recurrence interval

0.00

Averaged consecutive seven-day minimum discharge, in cubic feet per second, and 10-year recurrence interval

$\begin{array}{cccc}\text { November-April } & \text { November-December } & \text { January-February } & \text { March-April } \\ 0.00 & 0.00 & 1.49 & 8.11\end{array}$

Averaged consecutive seven-day minimum discharge, in cubic feet per second, and 10-year recurrence interval

$\begin{array}{cccccc}\text { November } & \text { December } & \text { January } & \text { February } & \text { March } & \text { April } \\ 0.00 & 0.44 & 1.55 & 8.48 & 14.1 & 8.51\end{array}$


Table 4. Low-flow characteristics for continuous streamflow-record gaging stations having 10 or more years of streamflow record.-Continued

07260500 Petit Jean River at Danville, Ark.

LOCATION.--Lat 3503’31.6”, long 93²3’44.2” referenced to North American Datum of 1983, in NW 1/4 SE 1/4 sec.25, T.5 N., R.23 W., Yell County, Ark., Hydrologic Unit 11110204, on right bank $125 \mathrm{ft}$ upstream of bridge on State Highway 10 at Danville, 0.3 mi upstream from old Chicago Rock Island and Pacific Railroad Co. Bridge, 0.5 mi upstream from Spring Creek, 0.6 mi downstream from Dutch Creek, and at mile 48.8 .

DRAINAGE AREA.--764 square miles.

PERIOD OF RECORD.--June 1916 to April 1946

REMARKS.-- Highly regulated after 1946 (highly altered).

Averaged consecutive seven-day minimum discharge, in cubic feet per second, and indicated recurrence interval

2-year recurrence interval

2.97 10-year recurrence interval

Averaged consecutive seven-day minimum discharge, in cubic feet per second, and 10-year recurrence interval

November-April

1.64
November-December

1.60
January-February

53.6
March-April

80.2

Averaged consecutive seven-day minimum discharge, in cubic feet per second, and 10-year recurrence interval

$\begin{array}{cccccc}\text { November } & \text { December } & \text { January } & \text { February } & \text { March } & \text { April } \\ 1.66 & 23.7 & 58.3 & 67.9 & 115 & 112\end{array}$

\section{Petit Jean River at Danville, Ark.}

LOCATION.--Lat 3503'31.6”, long 93²3'44.2” referenced to North American Datum of 1983, in NW 1/4 SE 1/4 sec.25, T.5 N., R.23 W., Yell County, Ark., Hydrologic Unit 11110204, on right bank $125 \mathrm{ft}$ upstream of bridge on State Highway 10 at Danville, 0.3 mi upstream from old Chicago Rock Island and Pacific Railroad Co. Bridge, 0.5 mi upstream from Spring Creek, 0.6 mi downstream from Dutch Creek, and at mile 48.8 .

DRAINAGE AREA.--764 square miles.

PERIOD OF RECORD.--May 1946 to September 2005.

REMARKS.-- Highly regulated after 1946 (highly altered).

Averaged consecutive seven-day minimum discharge, in cubic feet per second, and indicated recurrence interval

\section{2-year recurrence interval}

6.21 10-year recurrence interval

0.60

Averaged consecutive seven-day minimum discharge, in cubic feet per second, and 10-year recurrence interval
November-April
November-December
January-February
March-April
1.93
1.74
18.6
45.4

Averaged consecutive seven-day minimum discharge, in cubic feet per second, and 10-year recurrence interval

$\begin{array}{cccccc}\text { November } & \text { December } & \text { January } & \text { February } & \text { March } & \text { April } \\ 1.78 & 8.12 & 20.6 & 55.8 & 72.0 & 59.7\end{array}$


Table 4. Low-flow characteristics for continuous streamflow-record gaging stations having 10 or more years of streamflow record.-Continued

07261000 Cadron Creek near Guy, Ark.

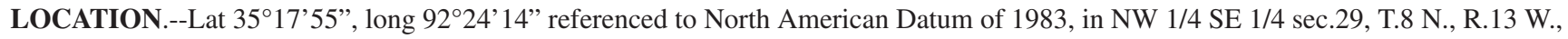
Faulkner County, Ark., Hydrologic Unit 11110205, on left bank on downstream side of bridge on U.S. Highway 65, 4.3 mi southwest of Guy, 10.5 mi upstream from Cove Creek, and at mile 48.3.

DRAINAGE AREA.--169 square miles.

PERIOD OF RECORD.--October 1954 to September 2005.

REMARKS.-- None.

Averaged consecutive seven-day minimum discharge, in cubic feet per second, and indicated recurrence interval

2-year recurrence interval

0.10

\section{0-year recurrence interval}

0.00

Averaged consecutive seven-day minimum discharge, in cubic feet per second, and 10-year recurrence interval

\section{November-April}

0.31

\section{November-December}

0.30
January-February

34.7
March-April

54.8

Averaged consecutive seven-day minimum discharge, in cubic feet per second, and 10-year recurrence interval

$\begin{array}{cccccc}\text { November } & \text { December } & \text { January } & \text { February } & \text { March } & \text { April } \\ 0.33 & 13.5 & 35.9 & 70.3 & 83.1 & 60.5\end{array}$

07261500 Fourche LaFave River near Gravelly, Ark.

LOCATION.--Lat 3452'24.0”, long 93³9'23.6”' referenced to North American Datum of 1927, in NW 1/4 NW 1/4 sec.34, T.3 N., R.25 W., Yell County, Ark., Hydrologic Unit 11110206, near left bank on downstream side of bridge on State Highway 28, 1.2 mi downstream from Garner Creek, 1.9 mi east of Gravelly, 6.4 mi upstream from Gaffords Creek, and at mile 103.7.

DRAINAGE AREA.--410 square miles.

PERIOD OF RECORD.--March 1939 to September 1994, October 1999 to September 2005.

REMARKS.-- None.

Averaged consecutive seven-day minimum discharge, in cubic feet per second, and indicated recurrence interval

2-year recurrence interval

0.70 10-year recurrence interval

0.00

Averaged consecutive seven-day minimum discharge, in cubic feet per second, and 10-year recurrence interval

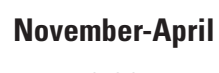

0.00
November-December

0.00
January-February

18.1
March-April

67.3

Averaged consecutive seven-day minimum discharge, in cubic feet per second, and 10-year recurrence interval

$\begin{array}{cccccc}\text { November } & \text { December } & \text { January } & \text { February } & \text { March } & \text { April } \\ 0.00 & 10.2 & 19.2 & 56.2 & 93.6 & 80.0\end{array}$


Table 4. Low-flow characteristics for continuous streamflow-record gaging stations having 10 or more years of streamflow record.-Continued

\section{Fourche LaFave River near Nimrod, Ark.}

LOCATION.--Lat 34 $57^{\prime} 02^{\prime}$, long 93 09' 16” in NE 1/4 SW 1/4 sec.32, T.4 N., R.20 W., Perry County, Ark., Hydrologic Unit 11110206, at Nimrod Dam 4.5 mi southwest of Nimrod.

DRAINAGE AREA.--684 square miles.

PERIOD OF RECORD.--April 1936 to September 1980.

REMARKS.-- Highly regulated (highly altered).

Averaged consecutive seven-day minimum discharge, in cubic feet per second, and indicated recurrence interval

2-year recurrence interval

2.31 10-year recurrence interval

0.28

Averaged consecutive seven-day minimum discharge, in cubic feet per second, and 10-year recurrence interval
November-April
November-December
January-February
March-April
0.64
0.67
9.71
12.3

Averaged consecutive seven-day minimum discharge, in cubic feet per second, and 10-year recurrence interval

$\begin{array}{cccccc}\text { November } & \text { December } & \text { January } & \text { February } & \text { March } & \text { April } \\ 0.79 & 3.42 & 10.9 & 37.1 & 29.6 & 20.3\end{array}$

007263000 South Fourche LaFave River near Hollis, Ark.

LOCATION.--Lat 3454'41”, long 9301'21”, in SE 1/4 NE 1/4 sec. 18, T.3 N., R.19 W., Perry County, Hydrologic Unit 11110206, on left bank 0.8 mi upstream from Big Cove Creek, 2.1 mi downstream from Cedar Creek, 4.0 mi northeast of Hollis, and at mile 5.6.

DRAINAGE AREA.--210 square miles.

PERIOD OF RECORD.--June 1941 to September 1995.

REMARKS.-- None.

Averaged consecutive seven-day minimum discharge, in cubic feet per second, and indicated recurrence interval

2-year recurrence interval

0.11 10-year recurrence interval

0.00

Averaged consecutive seven-day minimum discharge, in cubic feet per second, and 10-year recurrence interval

$\begin{array}{cccc}\text { November-April } & \text { November-December } & \text { January-February } & \text { March-April } \\ 0.13 & 0.12 & 13.3 & 24.6\end{array}$

Averaged consecutive seven-day minimum discharge, in cubic feet per second, and 10-year recurrence interval

$\begin{array}{cccccc}\text { November } & \text { December } & \text { January } & \text { February } & \text { March } & \text { April } \\ 0.13 & 7.98 & 14.0 & 38.3 & 39.2 & 29.1\end{array}$


Table 4. Low-flow characteristics for continuous streamflow-record gaging stations having 10 or more years of streamflow record.-Continued

07263295 Maumelle River at Williams Junction, Ark.

LOCATION.--Lat 34 ${ }^{\circ} 52^{\prime} 34^{\prime \prime}$, long 92 $46^{\prime} 28^{\prime \prime}$ referenced to North American Datum of 1927, in SE 1/4 NE 1/4 sec.26, T.3 N., R.17 W., Perry County, Ark., Hydrologic Unit 11110207, near left bank on downstream side of State Highway 9 bridge 0.4 mi south of Williams Junction.

DRAINAGE AREA.--46.1 square miles.

PERIOD OF RECORD.--October 1989 to September 2005.

REMARKS.-- None.

Averaged consecutive seven-day minimum discharge, in cubic feet per second, and indicated recurrence interval

2-year recurrence interval

0.00 10-year recurrence interval

0.00

Averaged consecutive seven-day minimum discharge, in cubic feet per second, and 10-year recurrence interval

$\begin{array}{cccc}\text { November-April } & \text { November-December } & \text { January-February } & \text { March-April } \\ 0.00 & 0.00 & 4.80 & 4.53\end{array}$

Averaged consecutive seven-day minimum discharge, in cubic feet per second, and 10-year recurrence interval

$\begin{array}{cccccc}\text { November } & \text { December } & \text { January } & \text { February } & \text { March } & \text { April } \\ 0.00 & 3.64 & 5.61 & 5.90 & 7.63 & 4.77\end{array}$

07263300 Maumelle River at Maumelle Dam at Natural Steps, Ark.

LOCATION.--Lat 3451'47”, long 92²9’07”' referenced to North American Datum of 1983, in SW 1/4 SE 1/4 sec.27, T.3 N., R.14 W., Pulaski County, Ark., Hydrologic Unit 11110207, at right bank $100 \mathrm{ft}$ upstream from spillway, 0.5 mi west of Natural Steps.

DRAINAGE AREA.--137 square miles.

PERIOD OF RECORD.--October 1989 to September 2005.

REMARKS.-- Highly regulated (highly altered).

Averaged consecutive seven-day minimum discharge, in cubic feet per second, and indicated recurrence interval

2-year recurrence interval

0.00 10-year recurrence interval

0.00

Averaged consecutive seven-day minimum discharge, in cubic feet per second, and 10-year recurrence interval
November-April
November-December
January-February
March-April
0.00
0.00
0.00
0.00

Averaged consecutive seven-day minimum discharge, in cubic feet per second, and 10-year recurrence interval

$\begin{array}{cccccc}\text { November } & \text { December } & \text { January } & \text { February } & \text { March } & \text { April } \\ 0.00 & 0.00 & 0.00 & 0.00 & 0.00 & 0.00\end{array}$


Table 4. Low-flow characteristics for continuous streamflow-record gaging stations having 10 or more years of streamflow record.-Continued

07263450 Arkansas River at Murray Dam near Little Rock, Ark.

LOCATION.--Lat 3447'27”, long 92²1’32” referenced to North American Datum of 1927, in sec.23, T.2 N., R.13 W., Pulaski County, Ark., Hydrologic Unit 11110207, in metal shelter on dam and at mile 141.5.

DRAINAGE AREA.--158,030 square miles, of which 22,241 square miles probably is noncontributing.

PERIOD OF RECORD.--April 1970 to September 2005.

REMARKS.-- Highly regulated (highly altered).

Averaged consecutive seven-day minimum discharge, in cubic feet per second, and indicated recurrence interval

2-year recurrence interval

2,320 10-year recurrence interval

819

Averaged consecutive seven-day minimum discharge, in cubic feet per second, and 10-year recurrence interval

\section{November-April}

1,440

\section{November-December}

1,420
January-February

4,520
March-April

6,460

Averaged consecutive seven-day minimum discharge, in cubic feet per second, and 10-year recurrence interval

$\begin{array}{cccccc}\text { November } & \text { December } & \text { January } & \text { February } & \text { March } & \text { April } \\ 1,570 & 3,160 & 4,720 & 7,160 & 8,990 & 9,000\end{array}$

07264000 Bayou Meto near Lonoke, Ark.

LOCATION.--Lat 3444'13”, long 9154'58”' referenced to North American Datum of 1927, in SW 1/4 sec.6, T.1 N., R.8 W., Lonoke County, Ark., Hydrologic Unit 08020402, near left bank on downstream side of bridge on State Highway 31, 3.0 mi upstream from Brushy Slough, and 3.5 miles south of Lonoke, and at mile 106.4.

DRAINAGE AREA.--207 square miles.

PERIOD OF RECORD.--October 1954 to September 2005.

REMARKS.-- Numerous anthropogenic alterations within basin (highly altered).

Averaged consecutive seven-day minimum discharge, in cubic feet per second, and indicated recurrence interval

2-year recurrence interval

2.28 10-year recurrence interval

0.03

Averaged consecutive seven-day minimum discharge, in cubic feet per second, and 10-year recurrence interval
November-April
November-December
January-February
March-April
0.88
0.81
17.5
38.3

Averaged consecutive seven-day minimum discharge, in cubic feet per second, and 10-year recurrence interval

$\begin{array}{cccccc}\text { November } & \text { December } & \text { January } & \text { February } & \text { March } & \text { April } \\ 0.79 & 7.58 & 18.5 & 50.4 & 76.0 & 37.8\end{array}$


Table 4. Low-flow characteristics for continuous streamflow-record gaging stations having 10 or more years of streamflow record.-Continued

07264500 Bayou Meto near Stuttgart, Ark.

LOCATION.--Lat 34²7' 15”, long 91 ${ }^{\circ} 36^{\prime} 58^{\prime \prime}$ in SE 1/4 sec.11, T.3 S., R.6 W., Arkansas County, Hydrologic Unit 08020402, at bridge on U.S. Highway 79, 5.5 mi southwest of Stuttgart.

DRAINAGE AREA.--574 square miles (At high stages, Bayou Meto and Crooked Creek are interconnected and the combined area is 653 square miles).

PERIOD OF RECORD.--October 1935 to September 1954.

REMARKS.-- Numerous anthropogenic alterations within basin (highly altered).

Averaged consecutive seven-day minimum discharge, in cubic feet per second, and indicated recurrence interval

2-year recurrence interval

0.00 10-year recurrence interval

0.00

Averaged consecutive seven-day minimum discharge, in cubic feet per second, and 10-year recurrence interval

$\begin{array}{cccc}\text { November-April } & \text { November-December } & \text { January-February } & \text { March-April } \\ 0.00 & 0.00 & 24.7 & 66.6\end{array}$

Averaged consecutive seven-day minimum discharge, in cubic feet per second, and 10-year recurrence interval

$\begin{array}{cccccc}\text { November } & \text { December } & \text { January } & \text { February } & \text { March } & \text { April } \\ 0.00 & 3.47 & 31.7 & 66.3 & 113 & 95.5\end{array}$

07265000 Crooked Creek near Humphrey, Ark.

LOCATION.--Lat 34²5’35”, long 9140’04”' in SE 1/4 sec.20, T.3 S., R.6 W., Arkansas County, Hydrologic Unit 08020402, at bridge on U.S. Highway 79, 2.3 mi east of Humphrey.

DRAINAGE AREA.--79.2 square miles.

PERIOD OF RECORD.--April 1940 to September 1954.

REMARKS.-- Numerous anthropogenic alterations within basin (highly altered).

Averaged consecutive seven-day minimum discharge, in cubic feet per second, and indicated recurrence interval

2-year recurrence interval

0.00 10-year recurrence interval

0.00

Averaged consecutive seven-day minimum discharge, in cubic feet per second, and 10-year recurrence interval

$\begin{array}{cccc}\text { November-April } & \text { November-December } & \text { January-February } & \text { March-April } \\ 0.00 & 0.00 & 0.00 & 5.80\end{array}$

Averaged consecutive seven-day minimum discharge, in cubic feet per second, and 10-year recurrence interval

$\begin{array}{cccccc}\text { November } & \text { December } & \text { January } & \text { February } & \text { March } & \text { April } \\ 0.00 & 0.00 & 0.00 & 3.54 & 7.82 & 12.8\end{array}$


Table 4. Low-flow characteristics for continuous streamflow-record gaging stations having 10 or more years of streamflow record.-Continued

\section{Red River at Index, Ark.}

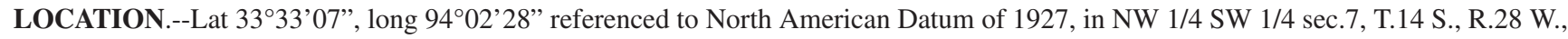
Miller County, Ark., Hydrologic Unit 11140106, near right bank on downstream side of southbound bridge on U.S. Highway 71 at Index, 2.2 mi south of Ogden, 20.6 mi upstream from Little River, and at mile 485.3.

DRAINAGE AREA.--48,030 square miles of which 5,936 square miles probably is noncontributing.

PERIOD OF RECORD.--January 1974 to September 2005.

REMARKS.-- Highly regulated (highly altered).

Averaged consecutive seven-day minimum discharge, in cubic feet per second, and indicated recurrence interval

2-year recurrence interval

1,880 10-year recurrence interval

1,240

Averaged consecutive seven-day minimum discharge, in cubic feet per second, and 10-year recurrence interval

\section{November-April}

1,430

\section{November-December}

1,430

\section{January-February}

1,780
March-April

2,180

Averaged consecutive seven-day minimum discharge, in cubic feet per second, and 10-year recurrence interval

$\begin{array}{cccccc}\text { November } & \text { December } & \text { January } & \text { February } & \text { March } & \text { April } \\ 1,400 & 1,690 & 1,780 & 2,680 & 2,420 & 2,670\end{array}$

07339500 Rolling Fork near DeQueen, Ark.

LOCATION.--Lat 3402'51”, long 94²4'47”, in SW 1/4 SW 1/4 sec. 21, T.8 S., R.32 W., Sevier County, Hydrologic Unit 11140109, near span on downstream side of brige on U.S. Highway 70, 4.0 mi west of De Queen.

DRAINAGE AREA.--182 square miles.

PERIOD OF RECORD.--October 1948 to September 1980 . Used October 1948 to December 1976.

REMARKS.-- None.

Averaged consecutive seven-day minimum discharge, in cubic feet per second, and indicated recurrence interval

2-year recurrence interval

1.84

\section{0-year recurrence interval}

0.16

Averaged consecutive seven-day minimum discharge, in cubic feet per second, and 10-year recurrence interval
November-April
November-December
January-February
March-April
1.14
1.17
13.5
23.3

Averaged consecutive seven-day minimum discharge, in cubic feet per second, and 10-year recurrence interval

$\begin{array}{cccccc}\text { November } & \text { December } & \text { January } & \text { February } & \text { March } & \text { April } \\ 1.19 & 6.41 & 14.2 & 36.8 & 38.4 & 23.6\end{array}$


Table 4. Low-flow characteristics for continuous streamflow-record gaging stations having 10 or more years of streamflow record.-Continued

07340000 Little River near Horatio, Ark.

LOCATION.--Lat 335' 10.3", long 94²3'12.1" referenced to North American Datum of 1983, in NE 1/4 sec.10, T.10 S., R.32 W., Sevier County, Ark., Hydrologic Unit 11140109, on left bank, downstream side of bridge on State Highway 41, 0.9 mi downstream from Rolling Fork, 2.0 mi southwest of Horatio, 28.5 mi upstream from Cossatot River, and at mile 72.0.

DRAINAGE AREA.--2,662 square miles.

PERIOD OF RECORD.--April 1931 to September 1968.

REMARKS.--Highly regulated after 1968.

Averaged consecutive seven-day minimum discharge, in cubic feet per second, and indicated recurrence interval

2-year recurrence interval

27.1

\section{0-year recurrence interval}

3.95

Averaged consecutive seven-day minimum discharge, in cubic feet per second, and 10-year recurrence interval

November-April

26.9
November-December

26.1
January-February

241
March-April

450

Averaged consecutive seven-day minimum discharge, in cubic feet per second, and 10-year recurrence interval

$\begin{array}{cccccc}\text { November } & \text { December } & \text { January } & \text { February } & \text { March } & \text { April } \\ 25.9 & 122 & 240 & 570 & 648 & 533\end{array}$

07340000 Little River near Horatio, Ark.

LOCATION.--Lat 335' 10.3”, long 94²3'12.1” referenced to North American Datum of 1983, in NE 1/4 sec.10, T.10 S., R.32 W., Sevier County, Ark., Hydrologic Unit 11140109, on left bank, downstream side of bridge on State Highway 41, 0.9 mi downstream from Rolling Fork, 2.0 mi southwest of Horatio, 28.5 mi upstream from Cossatot River, and at mile 72.0.

DRAINAGE AREA.--2,662 square miles.

PERIOD OF RECORD.--October 1968 to September 2005.

REMARKS.--Highly regulated after 1968 (highly altered).

Averaged consecutive seven-day minimum discharge, in cubic feet per second, and indicated recurrence interval

2-year recurrence interval

305 10-year recurrence interval

202

Averaged consecutive seven-day minimum discharge, in cubic feet per second, and 10-year recurrence interval

$\begin{array}{cccc}\text { November-April } & \text { November-December } & \text { January-February } & \text { March-April } \\ 244 & 226 & 416 & 442\end{array}$

Averaged consecutive seven-day minimum discharge, in cubic feet per second, and 10-year recurrence interval

$\begin{array}{cccccc}\text { November } & \text { December } & \text { January } & \text { February } & \text { March } & \text { April } \\ 204 & 365 & 441 & 645 & 636 & 557\end{array}$


Table 4. Low-flow characteristics for continuous streamflow-record gaging stations having 10 or more years of streamflow record.-Continued

07340300 Cossatot River near Vandervoort, Ark.

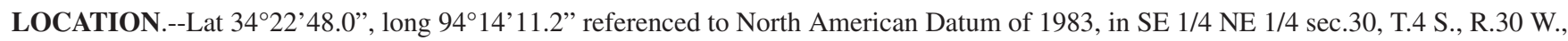
Polk County, Ark., Hydrologic Unit 11140109, on right bank $200 \mathrm{ft}$ upstream from bridge on State Highway 246, 0.3 mi downstream from Brushy Creek, 3.2 mi upstream from Flat Creek, and 7.5 mi east of Vandervoort.

DRAINAGE AREA.--89.6 square miles.

PERIOD OF RECORD.--June 1967 to September 2005.

REMARKS.--None.

Averaged consecutive seven-day minimum discharge, in cubic feet per second, and indicated recurrence interval

2-year recurrence interval

11.5 10-year recurrence interval

8.37

Averaged consecutive seven-day minimum discharge, in cubic feet per second, and 10-year recurrence interval

\section{November-April}

15.8

\section{November-December}

15.6
January-February

28.4
March-April

35.5

Averaged consecutive seven-day minimum discharge, in cubic feet per second, and 10-year recurrence interval

$\begin{array}{cccccc}\text { November } & \text { December } & \text { January } & \text { February } & \text { March } & \text { April } \\ 15.4 & 26.6 & 28.9 & 40.2 & 44.1 & 39.9\end{array}$

07340500 Cossatot River near DeQueen, Ark.

LOCATION.--Lat $34^{\circ} 02$ ' $45^{\prime}$, long $94^{\circ} 12^{\prime} 42^{\prime \prime}$ in NE 1/4 NE 1/4 sec.29, T.8 S., R.30 W., Sevier County, Hydrologic Unit 11140109, near right bank on downstream side of bridge on U.S. Highway 71, 7.0 mi east of DeQueen.

DRAINAGE AREA.--360 square miles.

PERIOD OF RECORD.--April 1938 to September 1980.

REMARKS.-- Highly regulated (highly altered).

Averaged consecutive seven-day minimum discharge, in cubic feet per second, and indicated recurrence interval

2-year recurrence interval

9.64 10-year recurrence interval

Averaged consecutive seven-day minimum discharge, in cubic feet per second, and 10-year recurrence interval

\section{November-April}

13.0
November-December

12.5
January-February

45.8
March-April

74.2

Averaged consecutive seven-day minimum discharge, in cubic feet per second, and 10-year recurrence interval

\section{November}

December

29.6
January

48.2
February

92.4
March

100
April

84.5 
Table 4. Low-flow characteristics for continuous streamflow-record gaging stations having 10 or more years of streamflow record.-Continued

07341000 Saline River near Dierks, Ark.

LOCATION.--Lat $34^{\circ} 05^{\prime} 45^{\prime \prime}$, long 9405’04”, in NW 1/4 SW 1/4 sec. 3, T.8 S., R.29 W., Howard County, Hydrologic Unit 11140109, near left bank on downstream side of U.S. Highway 70, 4.0 mi southwest of Dierks.

DRAINAGE AREA.--121 square miles.

PERIOD OF RECORD.--October 1938 to September 1980. Used October 1938 to April 1975.

REMARKS.-- None.

Averaged consecutive seven-day minimum discharge, in cubic feet per second, and indicated recurrence interval

2-year recurrence interval

0.27

\section{0-year recurrence interval}

0.00

Averaged consecutive seven-day minimum discharge, in cubic feet per second, and 10-year recurrence interval

\section{November-April}

0.32

\section{November-December}

0.30

\section{January-February}

9.90
March-April

18.0

Averaged consecutive seven-day minimum discharge, in cubic feet per second, and 10-year recurrence interval

$\begin{array}{cccccc}\text { November } & \text { December } & \text { January } & \text { February } & \text { March } & \text { April } \\ 0.30 & 4.24 & 10.4 & 28.1 & 26.3 & 20.9\end{array}$

\section{Saline River near Lockesburg, Ark.}

LOCATION.--Lat 3357'44.4”, long 9403'41.7” referenced to North American Datum of 1927, in NW 1/4 SE 1/4 sec.23, T.9 S., R.29 W., Sevier County, Ark., Hydrologic Unit 11140109, on right bank $50 \mathrm{ft}$ upstream from bridge on State Highway 371, $2.0 \mathrm{mi}$ downstream from Brushy Creek, 6.0 mi east of Lockesburg, and at mile 30.0.

DRAINAGE AREA.--256 square miles.

PERIOD OF RECORD.--July 1963 to April 1975.

REMARKS.-- Highly regulated after April 1975 (highly altered).

Averaged consecutive seven-day minimum discharge, in cubic feet per second, and indicated recurrence interval

2-year recurrence interval

0.97 10-year recurrence interval

0.32

Averaged consecutive seven-day minimum discharge, in cubic feet per second, and 10-year recurrence interval

\section{November-April}

1.04

\section{November-December}

0.98
January-February

14.0
March-April

22.0

Averaged consecutive seven-day minimum discharge, in cubic feet per second, and 10-year recurrence interval

$\begin{array}{cccccc}\text { November } & \text { December } & \text { January } & \text { February } & \text { March } & \text { April } \\ 0.92 & 2.75 & 14.3 & 43.6 & 45.0 & 21.4\end{array}$


Table 4. Low-flow characteristics for continuous streamflow-record gaging stations having 10 or more years of streamflow record.-Continued

07341200 Saline River near Lockesburg, Ark.

LOCATION.--Lat 335' 44.4”, long 9403'41.7”' referenced to North American Datum of 1927, in NW 1/4 SE 1/4 sec.23, T.9 S., R.29 W., Sevier County, Ark., Hydrologic Unit 11140109, on right bank $50 \mathrm{ft}$ upstream from bridge on State Highway $371,2.0$ mi downstream from Brushy Creek, 6.0 mi east of Lockesburg, and at mile 30.0.

DRAINAGE AREA.--256 square miles.

PERIOD OF RECORD.--May 1975 to September 2005.

REMARKS.-- Highly regulated after April 1975.

Averaged consecutive seven-day minimum discharge, in cubic feet per second, and indicated recurrence interval

2-year recurrence interval

10.8

\section{0-year recurrence interval}

5.17

Averaged consecutive seven-day minimum discharge, in cubic feet per second, and 10-year recurrence interval

$\begin{array}{cccc}\text { November-April } & \text { November-December } & \text { January-February } & \text { March-April } \\ 9.55 & 8.70 & 23.1 & 30.2\end{array}$

Averaged consecutive seven-day minimum discharge, in cubic feet per second, and 10-year recurrence interval

$\begin{array}{cccccc}\text { November } & \text { December } & \text { January } & \text { February } & \text { March } & \text { April } \\ 8.74 & 21.0 & 22.6 & 51.8 & 49.4 & 37.2\end{array}$

07341500 Red River at Fulton, Ark.

LOCATION.--Lat 33³6'26”, long 9348'56” in NE 1/4 SE 1/4 sec.20, T.13 S., R.26 W., Hempstead-Miller County line, Hydrologic Unit 11140201, near left bank on downstream side of bridge on U.S. Highway 67 at Fulton, 0.2 mi downstream from Missouri Pacific Railroad Co. bridge, 2.5 mi downstream from Little River, and at mile 463.0.

DRAINAGE AREA.--52,336 square miles, of which 5,936 square miles are probably noncontributing.

PERIOD OF RECORD.--January 1966 to September 1981.

REMARKS.-- Highly regulated (highly altered).

Averaged consecutive seven-day minimum discharge, in cubic feet per second, and indicated recurrence interval

2-year recurrence interval

2,200 10-year recurrence interval

1,120

Averaged consecutive seven-day minimum discharge, in cubic feet per second, and 10-year recurrence interval
November-April
November-December
January-February
March-April
1,380
1,390
2,250
2,680

Averaged consecutive seven-day minimum discharge, in cubic feet per second, and 10-year recurrence interval

$\begin{array}{cccccc}\text { November } & \text { December } & \text { January } & \text { February } & \text { March } & \text { April } \\ 1,500 & 2,060 & 2,240 & 3,040 & 2,970 & 2,740\end{array}$


Table 4. Low-flow characteristics for continuous streamflow-record gaging stations having 10 or more years of streamflow record.-Continued

07349430 Bodcau Creek at Stamps, Ark.

LOCATION.--Lat $33^{\circ} 22^{\prime} 00^{\prime \prime}$, long 93³1'20”, in NW 1/4 sec. 7, T.16 S., R.23 W., Lafayette County, Hydrologic Unit 11140205, near center of span on downstream side of bridge on U.S. Highway 82, 0.1 mi upstream from Tatum Branch, and 1 mi west of Stamps.

DRAINAGE AREA.--234 square miles.

PERIOD OF RECORD.-- October 1958 to September 1970.

REMARKS.-- None.

Averaged consecutive seven-day minimum discharge, in cubic feet per second, and indicated recurrence interval

2-year recurrence interval

0.08 10-year recurrence interval

0.00

Averaged consecutive seven-day minimum discharge, in cubic feet per second, and 10-year recurrence interval

$\begin{array}{cccc}\text { November-April } & \text { November-December } & \text { January-February } & \text { March-April } \\ 0.64 & 0.64 & 32.5 & 32.1\end{array}$

Averaged consecutive seven-day minimum discharge, in cubic feet per second, and 10-year recurrence interval

$\begin{array}{cccccc}\text { November } & \text { December } & \text { January } & \text { February } & \text { March } & \text { April } \\ 0.64 & 7.11 & 30.9 & 63.5 & 84.4 & 32.1\end{array}$

07356000 Ouachita River near Mount Ida, Ark.

LOCATION.--Lat 34³6’35.8”, long 9341'50.5” referenced to North American Datum of 1983, in SE 1/4 SW 1/4 sec.32, T.1 S., R.25 W., Montgomery County, Ark., Hydrologic Unit 08040101, on right bank, $350 \mathrm{ft}$ upstream from bridge on U.S. Highway $270,3.1 \mathrm{mi}$ upstream from Fiddler's Creek, 5.2 mi northwest of Mount Ida, and at mile 553.4.

DRAINAGE AREA.--414 square miles.

PERIOD OF RECORD.--October 1941 to September 2005.

REMARKS.-- None.

Averaged consecutive seven-day minimum discharge, in cubic feet per second, and indicated recurrence interval

2-year recurrence interval

22.3 10-year recurrence interval

8.39

Averaged consecutive seven-day minimum discharge, in cubic feet per second, and 10-year recurrence interval
November-April
November-December
January-February
March-April
31.5
30.7
85.8
123

Averaged consecutive seven-day minimum discharge, in cubic feet per second, and 10-year recurrence interval

$\begin{array}{cccccc}\text { November } & \text { December } & \text { January } & \text { February } & \text { March } & \text { April } \\ 30.8 & 67.8 & 91.0 & 147 & 175 & 135\end{array}$


Table 4. Low-flow characteristics for continuous streamflow-record gaging stations having 10 or more years of streamflow record.-Continued

07356500 South Fork Ouachita River at Mount Ida, Ark.

LOCATION.--Lat 33³4'37”, long 93³8'09”, in NE 1/4 sec. 23, T.2 S., R.25 W., Montgomery County, Hydrologic Unit 08040101, at bridge on U.S. Highway 270 at Mount Ida.

DRAINAGE AREA.--61.0 square miles.

PERIOD OF RECORD.--July 1949 to September 1970.

REMARKS.-- None.

Averaged consecutive seven-day minimum discharge, in cubic feet per second, and indicated recurrence interval

2-year recurrence interval

2.62 10-year recurrence interval

0.13

Averaged consecutive seven-day minimum discharge, in cubic feet per second, and 10-year recurrence interval November-April

4.77

\begin{abstract}
November-December
\end{abstract} 4.76

March-April

13.6

Averaged consecutive seven-day minimum discharge, in cubic feet per second, and 10-year recurrence interval

$\begin{array}{cccccc}\text { November } & \text { December } & \text { January } & \text { February } & \text { March } & \text { April } \\ 4.82 & 6.40 & 8.40 & 15.3 & 18.3 & 13.4\end{array}$

07359002 Ouachita River at Remmel Dam above Jones Mill, Ark.

LOCATION.--Lat 34²5’35”, long 92 53’27’ referenced to North American Datum of 1927, in SW 1/4 NW 1/4 sec.36, T.3 S., R.18 W., Hot Spring County, Ark., Hydrologic Unit 08040102, at right bank 1,000 ft downstream from Remmel Dam and 0.8 mi above Jones Mill.

DRAINAGE AREA.--1,550 square miles.

PERIOD OF RECORD.--April 1954 to September 2005.

REMARKS.-- Highly regulated (highly altered).

Averaged consecutive seven-day minimum discharge, in cubic feet per second, and indicated recurrence interval

2-year recurrence interval

406 10-year recurrence interval

271

Averaged consecutive seven-day minimum discharge, in cubic feet per second, and 10-year recurrence interval
November-April
November-December
January-February
March-April
290
335
399
332

Averaged consecutive seven-day minimum discharge, in cubic feet per second, and 10-year recurrence interval

$\begin{array}{cccccc}\text { November } & \text { December } & \text { January } & \text { February } & \text { March } & \text { April } \\ 417 & 394 & 444 & 546 & 424 & 353\end{array}$


Table 4. Low-flow characteristics for continuous streamflow-record gaging stations having 10 or more years of streamflow record.-Continued

07359610 Caddo River near Caddo Gap, Ark.

LOCATION.--Lat 34²2'58.7”, long 93³6'20.6" referenced to North American Datum of 1983, in SW 1/4 NE 1/4 sec.19, T.4 S., R.24 W., Montgomery County, Ark., Hydrologic Unit 08040102, on downstream side of bridge on State Highway 240, 1.3 mi southeast of Caddo Gap, Arkansas.

DRAINAGE AREA.--136 square miles.

PERIOD OF RECORD.--October 1988 to September 2005.

REMARKS.-- None.

Averaged consecutive seven-day minimum discharge, in cubic feet per second, and indicated recurrence interval

2-year recurrence interval

33.4 10-year recurrence interval

26.4

Averaged consecutive seven-day minimum discharge, in cubic feet per second, and 10-year recurrence interval

November-April

46.5
November-December

44.7
January-February

59.4
March-April

79.2

Averaged consecutive seven-day minimum discharge, in cubic feet per second, and 10-year recurrence interval November

December

January

February

March

April

43.6

59.2

62.2

69.7

96.7

\section{Ouachita River at Blakely Mountain Dam near Hot Springs, Ark.}

LOCATION.--Lat 34³4'18”, long 93¹1'37”' in SE 1/4 sec.12, T.2 S., R.21 W., Garland County, Hydrologic Unit 08040101, on outlet of power tunnel at Blakely Mountain Dam, 2.3 mi upstream from Glazypeau Creek, 10.0 mi northwest of Hot Springs, and at mile 486.9.

DRAINAGE AREA.--1,105 square miles.

PERIOD OF RECORD.--October 1952 to September 1977.

REMARKS.-- Highly regulated (highly altered).

Averaged consecutive seven-day minimum discharge, in cubic feet per second, and indicated recurrence interval

2-year recurrence interval

34.0 10-year recurrence interval

$$
6.51
$$

Averaged consecutive seven-day minimum discharge, in cubic feet per second, and 10-year recurrence interval
November-April
November-December
January-February
March-April
10.8
46.6
12.3
15.6

Averaged consecutive seven-day minimum discharge, in cubic feet per second, and 10-year recurrence interval

$\begin{array}{cccccc}\text { November } & \text { December } & \text { January } & \text { February } & \text { March } & \text { April } \\ 125 & 64.1 & 32.2 & 16.8 & 22.6 & 21.8\end{array}$


Table 4. Low-flow characteristics for continuous streamflow-record gaging stations having 10 or more years of streamflow record.-Continued

07359800 Caddo River near Alpine, Ark.

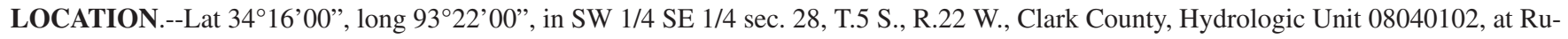
nyan Bridge, 2.8 mi northeast of Alpine.

DRAINAGE AREA.--301 square miles.

PERIOD OF RECORD.--October 1938 to September 1970.

REMARKS.-- None.

Averaged consecutive seven-day minimum discharge, in cubic feet per second, and indicated recurrence interval

2-year recurrence interval

27.3 10-year recurrence interval

12.6

Averaged consecutive seven-day minimum discharge, in cubic feet per second, and 10-year recurrence interval November-April

34.2

\section{November-December}

33.6
January-February

65.4
March-April

83.7

Averaged consecutive seven-day minimum discharge, in cubic feet per second, and 10-year recurrence interval

$\begin{array}{cccccc}\text { November } & \text { December } & \text { January } & \text { February } & \text { March } & \text { April } \\ 37.5 & 41.8 & 66.5 & 101 & 111 & 91.6\end{array}$

07360000 Ouachita River at Arkadelphia, Ark.

LOCATION.--Lat 3407'16”, long 9302'46” in sec.17, T.7 S., R.19 W., Clark County, Hydrologic Unit 08040102, on downstream side of bridge on State Highway 7 at Arkadelphia, 5.4 mi downstream from Caddo River, and at mile 420.6.

DRAINAGE AREA.--2,311 square miles.

PERIOD OF RECORD.--October 1952 to September 1977.

REMARKS.-- Highly regulated (highly altered).

Averaged consecutive seven-day minimum discharge, in cubic feet per second, and indicated recurrence interval

2-year recurrence interval

442
10 -year recurrence interval

255

Averaged consecutive seven-day minimum discharge, in cubic feet per second, and 10-year recurrence interval
November-April
November-December
326
January-February
472
March-April
462

Averaged consecutive seven-day minimum discharge, in cubic feet per second, and 10-year recurrence interval

$\begin{array}{cccccc}\text { November } & \text { December } & \text { January } & \text { February } & \text { March } & \text { April } \\ 412 & 462 & 522 & 790 & 653 & 439\end{array}$


Table 4. Low-flow characteristics for continuous streamflow-record gaging stations having 10 or more years of streamflow record.-Continued

07360501 Little Missouri River at Narrows Dam near Murfreesboro, Ark.

LOCATION.--Lat $34^{\circ} 08^{\prime}$ '54", long 934' '54" in NW 1/4 sec.18, T.7 S., R.25 W., Pike County, Hydrologic Unit 08040103, in powerhouse at Narrows Dam, 6.5 mi northwest of Murfreesboro, 9.7 mi upstream from Muddy Fork, and at mile 105.5.

DRAINAGE AREA.--237 square miles.

PERIOD OF RECORD.--January 1951 to September 1977.

REMARKS.-- Highly regulated (highly altered).

Averaged consecutive seven-day minimum discharge, in cubic feet per second, and indicated recurrence interval

2-year recurrence interval

11.9 10-year recurrence interval

6.63

Averaged consecutive seven-day minimum discharge, in cubic feet per second, and 10-year recurrence interval

November-April

5.90

\section{November-December}

7.13
January-February

8.84
March-April

9.20

Averaged consecutive seven-day minimum discharge, in cubic feet per second, and 10-year recurrence interval

November

14.4

\section{December}

9.65
January

12.6
February

13.3
March

12.3
April

10.8

07361000 Little Missouri River near Murfreesboro, Ark.

LOCATION.--Lat 3402'55”, long 9343'12”, in NE 1/4 NE 1/4 sec. 24, T.8 S., R.26 W., Pike County, Hydrologic Unit 08040103, near right bank on downstream side of bridge on State Highway 27, 1.8 mi downstream from Muddy Fork Creek, 2.0 mi southwest of Murfreesboro, 4.6 mi upstream from Prairie Creek, 11.4 mi downstream from Lake Greeson, and at mile 94.1.

DRAINAGE AREA.--380 square miles.

PERIOD OF RECORD.--April 1928 to March 1950.

REMARKS.-- Highly regulated after March 1950.

Averaged consecutive seven-day minimum discharge, in cubic feet per second, and indicated recurrence interval

\section{2-year recurrence interval}

7.57 10-year recurrence interval 3.68

Averaged consecutive seven-day minimum discharge, in cubic feet per second, and 10-year recurrence interval
November-April
November-December
January-February
March-April
15.6
13.4
65.5
78.5

Averaged consecutive seven-day minimum discharge, in cubic feet per second, and 10-year recurrence interval

$\begin{array}{cccccc}\text { November } & \text { December } & \text { January } & \text { February } & \text { March } & \text { April } \\ 15.4 & 27.8 & 71.2 & 77.3 & 81.5 & 126\end{array}$


Table 4. Low-flow characteristics for continuous streamflow-record gaging stations having 10 or more years of streamflow record.-Continued

07361000 Little Missouri River near Murfreesboro, Ark.

LOCATION.--Lat 3402'55”, long 9343'12”, in NE 1/4 NE 1/4 sec. 24, T.8 S., R.26 W., Pike County, Hydrologic Unit 08040103, near right bank on downstream side of bridge on State Highway 27, 1.8 mi downstream from Muddy Fork Creek, 2.0 mi southwest of Murfreesboro, 4.6 mi upstream from Prairie Creek, 11.4 mi downstream from Lake Greeson, and at mile 94.1.

DRAINAGE AREA.--380 square miles.

PERIOD OF RECORD.--April 1950 to September 1977.

REMARKS.-- Highly regulated after March 1950.

Averaged consecutive seven-day minimum discharge, in cubic feet per second, and indicated recurrence interval

2-year recurrence interval

21.6
10 -year recurrence interval

9.59

Averaged consecutive seven-day minimum discharge, in cubic feet per second, and 10-year recurrence interval

\section{November-April}

11.7
November-December

13.3
January-February

20.1
March-April

27.0

Averaged consecutive seven-day minimum discharge, in cubic feet per second, and 10-year recurrence interval

$\begin{array}{cccccc}\text { November } & \text { December } & \text { January } & \text { February } & \text { March } & \text { April } \\ 20.7 & 22.2 & 22.2 & 55.1 & 59.6 & 24.8\end{array}$

07361500 Antoine River at Antoine, Ark.

LOCATION.--Lat 3402’20”, long 93²5’05”' referenced to North American Datum of 1927, in NW 1/4 NW 1/4 sec.24, T.8 S., R.23 W., Pike County, Ark., Hydrologic Unit 08040103, near right bank on downstream side of bridge on State Highway 26 at Antoine, 1.6 mi downstream from Brushy Creek, 1.9 mi downstream from Suck Creek, and at mile 8.5.

DRAINAGE AREA.--178 square miles.

PERIOD OF RECORD.--October 1954 to September 2005.

REMARKS.-- None.

Averaged consecutive seven-day minimum discharge, in cubic feet per second, and indicated recurrence interval

2-year recurrence interval

0.40

\section{0-year recurrence interval}

0.00

Averaged consecutive seven-day minimum discharge, in cubic feet per second, and 10-year recurrence interval
November-April
November-December
January-February
March-April
0.76
0.72
18.0
26.2

Averaged consecutive seven-day minimum discharge, in cubic feet per second, and 10-year recurrence interval

$\begin{array}{cccccc}\text { November } & \text { December } & \text { January } & \text { February } & \text { March } & \text { April } \\ 0.71 & 7.96 & 19.1 & 50.0 & 55.3 & 27.5\end{array}$


Table 4. Low-flow characteristics for continuous streamflow-record gaging stations having 10 or more years of streamflow record.-Continued

07361600 Little Missouri River near Boughton, Ark.

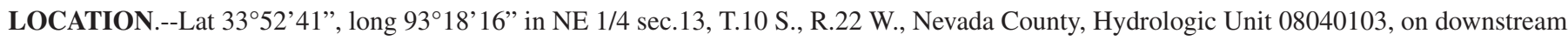
side of bridge on U.S. Highway 67, 1.5 mi northeast of Boughton, 5.9 mi downstream from Howard Creek, 10.2 mi downstream from Antoine River, and at mile 46.8 .

DRAINAGE AREA.--1,068 square miles.

PERIOD OF RECORD.--January 1951 to September 1977.

REMARKS.-- Highly regulated (highly altered).

Averaged consecutive seven-day minimum discharge, in cubic feet per second, and indicated recurrence interval

2-year recurrence interval

64.0 10-year recurrence interval

27.8

Averaged consecutive seven-day minimum discharge, in cubic feet per second, and 10-year recurrence interval

\section{November-April}

37.1

\section{November-December}

35.4
January-February

83.7
March-April

122

Averaged consecutive seven-day minimum discharge, in cubic feet per second, and 10-year recurrence interval

\section{November}

42.7

\section{December}

68.7

\section{January}

87.4

\section{February}

248
March

252
April

119

\section{Ouachita River at Camden, Ark.}

LOCATION.--Lat 33³5'47”, long 9249’05” referenced to North American Datum of 1927, in SE 1/4 sec.14, T.13 S., R.17 W., Ouachita County, Ark., Hydrologic Unit 08040102, at bridge on U.S. Highway 79B at Camden, 3.4 mi downstream from Ecore Fabre Bayou, 6.2 mi upstream from Two Bayou Creek, and at mile 354.1.

DRAINAGE AREA.--5,357 square miles.

PERIOD OF RECORD.--October 1928 to July 1969.

REMARKS.-- Regulated by a series of dams and lakes August 1969 - March 1985. Regulated by additional dams after March 1985.

Averaged consecutive seven-day minimum discharge, in cubic feet per second, and indicated recurrence interval

2-year recurrence interval

469

\section{0-year recurrence interval}

200

Averaged consecutive seven-day minimum discharge, in cubic feet per second, and 10-year recurrence interval

\section{November-April}

403

\section{November-December}

408

\section{January-February}

1,000
March-April

1,260

Averaged consecutive seven-day minimum discharge, in cubic feet per second, and 10-year recurrence interval

$\begin{array}{cccccc}\text { November } & \text { December } & \text { January } & \text { February } & \text { March } & \text { April } \\ 426 & 695 & 1,120 & 1,510 & 1,960 & 1,300\end{array}$


Table 4. Low-flow characteristics for continuous streamflow-record gaging stations having 10 or more years of streamflow record.-Continued

07362000 Ouachita River at Camden, Ark.

LOCATION.--Lat 33³5'47”, long 9249’05” referenced to North American Datum of 1927, in SE 1/4 sec.14, T.13 S., R.17 W., Ouachita County, Ark., Hydrologic Unit 08040102, at bridge on U.S. Highway 79B at Camden, 3.4 mi downstream from Ecore Fabre Bayou, 6.2 mi upstream from Two Bayou Creek, and at mile 354.1.

DRAINAGE AREA.--5,357 square miles.

PERIOD OF RECORD.--August 1969 to March 1985.

REMARKS.-- Regulated by a series of dams and lakes August 1969 - March 1985. Regulated by additional dams after March 1985.

Averaged consecutive seven-day minimum discharge, in cubic feet per second, and indicated recurrence interval

2-year recurrence interval

858

\section{0-year recurrence interval}

584

Averaged consecutive seven-day minimum discharge, in cubic feet per second, and 10-year recurrence interval

\section{November-April}

903
November-December

864
January-February

1,830
March-April

1,340

Averaged consecutive seven-day minimum discharge, in cubic feet per second, and 10-year recurrence interval

$\begin{array}{cccccc}\text { November } & \text { December } & \text { January } & \text { February } & \text { March } & \text { April } \\ 831 & 1,580 & 1,830 & 3,290 & 2,400 & 1,320\end{array}$

\section{Ouachita River at Camden, Ark.}

LOCATION.--Lat 33³5'47”, long 9249'05”' referenced to North American Datum of 1927, in SE 1/4 sec.14, T.13 S., R.17 W., Ouachita County, Ark., Hydrologic Unit 08040102, at bridge on U.S. Highway 79B at Camden, 3.4 mi downstream from Ecore Fabre Bayou, 6.2 mi upstream from Two Bayou Creek, and at mile 354.1.

DRAINAGE AREA.--5,357 square miles.

PERIOD OF RECORD.--April 1985 to September 2005.

REMARKS.-- Regulated by a series of dams and lakes August 1969 - March 1985. Regulated by additional dams after March 1985.

Averaged consecutive seven-day minimum discharge, in cubic feet per second, and indicated recurrence interval

2-year recurrence interval

952 10-year recurrence interval

708

Averaged consecutive seven-day minimum discharge, in cubic feet per second, and 10-year recurrence interval

\section{November-April}

891

\section{November-December}

907

\section{January-February}

1,590
March-April

1,470

Averaged consecutive seven-day minimum discharge, in cubic feet per second, and 10-year recurrence interval

$\begin{array}{cccccc}\text { November } & \text { December } & \text { January } & \text { February } & \text { March } & \text { April } \\ 956 & 1,250 & 1,730 & 2,120 & 1,930 & 1,880\end{array}$


Table 4. Low-flow characteristics for continuous streamflow-record gaging stations having 10 or more years of streamflow record.-Continued

07362100 Smackover Creek near Smackover, Ark.

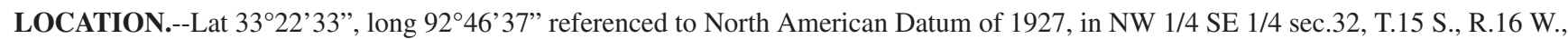
Union County, Ark., Hydrologic Unit 08040201, near right bank on downstream side of bridge on State Highway 7, 0.1 mi downstream from Camp Creek, 3.3 mi northwest of Smackover, and at mile 22.0.

DRAINAGE AREA.--385 square miles.

PERIOD OF RECORD.--October 1961 to September 2005.

REMARKS.-- None.

Averaged consecutive seven-day minimum discharge, in cubic feet per second, and indicated recurrence interval

2-year recurrence interval
10 -year recurrence interval

0.34

Averaged consecutive seven-day minimum discharge, in cubic feet per second, and 10-year recurrence interval

November-April

4.55
November-December

4.45
January-February
March-April

49.5

Averaged consecutive seven-day minimum discharge, in cubic feet per second, and 10-year recurrence interval

$\begin{array}{cccccc}\text { November } & \text { December } & \text { January } & \text { February } & \text { March } & \text { April } \\ 4.42 & 22.4 & 39.1 & 77.4 & 86.2 & 50.9\end{array}$

07362500 Moro Creek near Fordyce, Ark.

LOCATION.--Lat 3347’32”, long 92²0’00” referenced to North American Datum of 1983, in NW 1/4 NW 1/4 sec.3, T.11 S., R.12 W., Calhoun County, Ark., Hydrologic Unit 08040201, on downstream side of bridge on State Highway 8, 5.0 mi southeast of Fordyce.

DRAINAGE AREA.--240 square miles.

PERIOD OF RECORD.--October 1951 to September 1983, October 2001 to September 2005.

REMARKS.-- None.

Averaged consecutive seven-day minimum discharge, in cubic feet per second, and indicated recurrence interval

2-year recurrence interval

0.00
10 -year recurrence interval

0.00

Averaged consecutive seven-day minimum discharge, in cubic feet per second, and 10-year recurrence interval

\section{November-April}

0.00
November-December

0.00
January-February

1.30
March-April

10.8

Averaged consecutive seven-day minimum discharge, in cubic feet per second, and 10-year recurrence interval

\section{November}

0.00
December

0.17
January

1.26
February

20.7
March

28.2
April

10.6 
Table 4. Low-flow characteristics for continuous streamflow-record gaging stations having 10 or more years of streamflow record.-Continued

07362587 Alum Fork Saline River near Reform, Ark.

LOCATION.--Lat 34 ${ }^{\circ} 77^{\prime} 51^{\prime \prime}$, long 92 $56^{\prime} 00^{\prime \prime}$ referenced to North American Datum of 1927, in NW 1/4 NE 1/4 sec.29, T.2 N., R.18 W., Saline County, Ark., Hydrologic Unit 08040203, on left bank $100 \mathrm{ft}$ above low-water bridge on forest road, $5.7 \mathrm{mi}$ west of Reform.

DRAINAGE AREA.--27.0 square miles.

PERIOD OF RECORD.--October 1989 to September 2005.

REMARKS.-- None.

Averaged consecutive seven-day minimum discharge, in cubic feet per second, and indicated recurrence interval

2-year recurrence interval

0.00 10-year recurrence interval

0.00

Averaged consecutive seven-day minimum discharge, in cubic feet per second, and 10-year recurrence interval

November-April

0.29
November-December

0.26
January-February

2.86
March-April

4.38

Averaged consecutive seven-day minimum discharge, in cubic feet per second, and 10-year recurrence interval

$\begin{array}{cccccc}\text { November } & \text { December } & \text { January } & \text { February } & \text { March } & \text { April } \\ 0.26 & 1.66 & 3.36 & 3.53 & 7.51 & 4.32\end{array}$

07363000 Saline River at Benton, Ark.

LOCATION.--Lat 34³4’05”, long 92³6’38” referenced to North American Datum of 1927, in SW 1/4 NE 1/4 sec.9, T.2 S., R.15 W., Saline County, Ark., Hydrologic Unit 08040203, on left bank three-quarters of a mile west of Benton, 3.0 mi downstream from confluence of North Fork and Alum Fork, and at mile 198.1.

DRAINAGE AREA.--550 square miles.

PERIOD OF RECORD.--October 1950 to September 1979, October 1983 to September 1984, and October 2000 to September 2005.

REMARKS.-- Highly regulated (highly altered).

Averaged consecutive seven-day minimum discharge, in cubic feet per second, and indicated recurrence interval

2-year recurrence interval

22.5 10-year recurrence interval

2.67

Averaged consecutive seven-day minimum discharge, in cubic feet per second, and 10-year recurrence interval

\section{November-April}

29.3
November-December

29.1
January-February

93.5
March-April

124

Averaged consecutive seven-day minimum discharge, in cubic feet per second, and 10-year recurrence interval

$\begin{array}{cccccc}\text { November } & \text { December } & \text { January } & \text { February } & \text { March } & \text { April } \\ 28.4 & 67.9 & 94.6 & 172 & 205 & 120\end{array}$


Table 4. Low-flow characteristics for continuous streamflow-record gaging stations having 10 or more years of streamflow record.-Continued

07363200 Saline River near Sheridan, Ark.

LOCATION.--Lat 3406'56", long 92²4'21" referenced to North American Datum of 1927, in NE 1/4 NW 1/4 sec.15, T.7 S., R.13 W., Grant County, Ark., Hydrologic Unit 08040203, on downstream side of bridge on U.S. Highway 167, 13.5 mi south of Sheridan.

DRAINAGE AREA.--1,123 square miles.

PERIOD OF RECORD.--October 1970 to September 1982 and October 2000 to September 2005.

REMARKS.-- Numerous anthropogenic alterations within basin (highly altered).

Averaged consecutive seven-day minimum discharge, in cubic feet per second, and indicated recurrence interval

2-year recurrence interval

37.2 10-year recurrence interval

14.1

Averaged consecutive seven-day minimum discharge, in cubic feet per second, and 10-year recurrence interval

$\begin{array}{cccc}\text { November-April } & \text { November-December } & \text { January-February } & \text { March-April } \\ 58.5 & 55.9 & 264 & 290\end{array}$

Averaged consecutive seven-day minimum discharge, in cubic feet per second, and 10-year recurrence interval

$\begin{array}{cccccc}\text { November } & \text { December } & \text { January } & \text { February } & \text { March } & \text { April } \\ 52.1 & 214 & 263 & 476 & 455 & 262\end{array}$

07363400 Hurricane Creek below Sheridan, Ark.

LOCATION.--Lat 34¹3’42”, long 92²2’21” referenced to North American Datum of 1927, in SW 1/4 NW 1/4 sec.1, T.6 S., R.13 W., Grant County, Ark., Hydrologic Unit 08040203, on downstream side of bridge on State Highway 35, 6.0 mi south of Sheridan.

DRAINAGE AREA.--261 square miles.

PERIOD OF RECORD.--October 1995 to September 2005.

REMARKS.-- Numerous anthropogenic alterations within basin (highly altered).

Averaged consecutive seven-day minimum discharge, in cubic feet per second, and indicated recurrence interval

2-year recurrence interval

0.00 10-year recurrence interval

0.00

Averaged consecutive seven-day minimum discharge, in cubic feet per second, and 10-year recurrence interval

November-April

0.00
November-December

0.00
January-February

10.6
March-April

27.8

Averaged consecutive seven-day minimum discharge, in cubic feet per second, and 10-year recurrence interval

\section{November}

0.00
December

5.00
January

11.4
February

15.1
March

57.8
April 
Table 4. Low-flow characteristics for continuous streamflow-record gaging stations having 10 or more years of streamflow record.-Continued

07363500 Saline River near Rye, Ark.

LOCATION.--Lat 3342'03", long 9201'33" referenced to North American Datum of 1927, in SW 1/4 NE 1/4 sec.3, T.12 S., R.9 W., Bradley County, Ark., Hydrologic Unit 08040204, near left bank on downstream side of bridge on U.S. Highway 63, 3.6 mi southwest of Rye, 5.8 mi upstream from Hudgin Creek, and at mile 71.0.

DRAINAGE AREA.--2,102 square miles, (revised 1979).

PERIOD OF RECORD.--October 1937 to September 2005.

REMARKS.-- Numerous anthropogenic alterations within basin (highly altered).

Averaged consecutive seven-day minimum discharge, in cubic feet per second, and indicated recurrence interval

2-year recurrence interval

39.2

\section{0-year recurrence interval}

13.1

Averaged consecutive seven-day minimum discharge, in cubic feet per second, and 10-year recurrence interval

\section{November-April}

42.8
November-December

41.7
January-February

231
March-April

406

Averaged consecutive seven-day minimum discharge, in cubic feet per second, and 10-year recurrence interval

$\begin{array}{cccccc}\text { November } & \text { December } & \text { January } & \text { February } & \text { March } & \text { April } \\ 41.7 & 126 & 242 & 433 & 663 & 442\end{array}$

07364133 Bayou Bartholomew at Garrett Bridge, Ark.

LOCATION.--Lat 3351'59”, long 91³9’22” referenced to North American Datum of 1983, in SE 1/4 SW 1/4 sec.6, T.12 S., R.3 W., Lincoln County, Ark., Hydrologic Unit 08040205, on downstream side of bridge on State Highway 54, 1.9 mi upstream from Flat Creek at Garrett Bridge.

DRAINAGE AREA.--380 square miles.

PERIOD OF RECORD.--October 1987 to September 2005.

REMARKS.-- Numerous anthropogenic alterations within basin (highly altered).

Averaged consecutive seven-day minimum discharge, in cubic feet per second, and indicated recurrence interval

2-year recurrence interval

4.96 10-year recurrence interval

0.36

Averaged consecutive seven-day minimum discharge, in cubic feet per second, and 10-year recurrence interval

\section{November-April}

2.49
November-December

2.49
January-February

43.6
March-April

49.5

Averaged consecutive seven-day minimum discharge, in cubic feet per second, and 10-year recurrence interval

$\begin{array}{cccccc}\text { November } & \text { December } & \text { January } & \text { February } & \text { March } & \text { April } \\ 2.51 & 13.1 & 44.6 & 80.0 & 108 & 51.0\end{array}$


Table 4. Low-flow characteristics for continuous streamflow-record gaging stations having 10 or more years of streamflow record.-Continued

07364150 Bayou Bartholomew near McGehee, Ark.

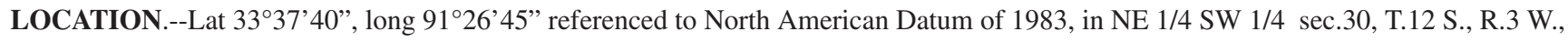
Desha County, Ark., Hydrologic Unit 08040205, near center of stream on downstream side of bridge on State Highway 278, 2.7 mi west of McGehee, 17.5 mi downstream from Ables Creek, at mile 200.5.

DRAINAGE AREA.--576 square miles.

PERIOD OF RECORD.--October 1938 to September 1942 and October 1945 to September 2005.

REMARKS.-- Numerous anthropogenic alterations within basin (highly altered).

Averaged consecutive seven-day minimum discharge, in cubic feet per second, and indicated recurrence interval

2-year recurrence interval

26.2 10-year recurrence interval

5.49

Averaged consecutive seven-day minimum discharge, in cubic feet per second, and 10-year recurrence interval

\section{November-April}

15.4

Avera

\section{January-February}

60.1
March-April

102

\section{December}

27.4

\begin{abstract}
January
\end{abstract}
65.9
February

124
April

106

\section{Cornie Bayou near Three Creeks, Ark.}

LOCATION.--Lat 3302’21”, long 92 56’15”, in SW 1/4 NW 1/4 sec. 36, T.19 S., R.18 W., Union County, Hydrologic Unit 08040206, on left bank at downstream side of bridge on State Highway 15, 3.4 mi downstream from Pigeon Creek, and 6.0 mi southwest of town of Three Creeks.

DRAINAGE AREA.--180 square miles.

PERIOD OF RECORD.--April 1956 to September 1987.

REMARKS.-- None.

Averaged consecutive seven-day minimum discharge, in cubic feet per second, and indicated recurrence interval

2-year recurrence interval

0.20 10-year recurrence interval

0.00

Averaged consecutive seven-day minimum discharge, in cubic feet per second, and 10-year recurrence interval

\section{November-April}

0.26

\section{November-December}

0.26

\section{January-February}

11.3
March-April

12.0

Averaged consecutive seven-day minimum discharge, in cubic feet per second, and 10-year recurrence interval

$\begin{array}{cccccc}\text { November } & \text { December } & \text { January } & \text { February } & \text { March } & \text { April } \\ 0.27 & 4.88 & 11.0 & 22.3 & 25.6 & 11.6\end{array}$


Table 4. Low-flow characteristics for continuous streamflow-record gaging stations having 10 or more years of streamflow record.-Continued

07365900 Three Creeks near Three Creeks, Ark.

LOCATION.--Lat 3304'01”, long 92 53'02”, in NW 1/4 sec. 20, T.19 N., R.7 W., Union County, Hydrologic Unit 08040206, at bridge on State Highway 15, 2.2 mi southwest of the town of Three Creeks.

DRAINAGE AREA.--50.4 square miles.

PERIOD OF RECORD.--October 1957 to September 1971.

REMARKS.-- None.

Averaged consecutive seven-day minimum discharge, in cubic feet per second, and indicated recurrence interval

2-year recurrence interval

0.26 10-year recurrence interval

0.00

Averaged consecutive seven-day minimum discharge, in cubic feet per second, and 10-year recurrence interval

November-April

0.58

November-December

0.59
January-February

3.14
March-April

2.41

Averaged consecutive seven-day minimum discharge, in cubic feet per second, and 10-year recurrence interval

$\begin{array}{cccccc}\text { November } & \text { December } & \text { January } & \text { February } & \text { March } & \text { April } \\ 0.59 & 0.82 & 3.10 & 5.25 & 4.39 & 2.48\end{array}$

07369680 Bayou Macon at Eudora, Ark.

LOCATION.--Lat 3306'09”, long 91¹5'08” referenced to North American Datum of 1927, SESES25T18SR02W, Chicot County, Ark., Hydrologic Unit 08050002, near left bank on downstream side of bridge on U.S. Highway 65, 0.6 mi south of Eudora.

DRAINAGE AREA.--500 square miles.

PERIOD OF RECORD.--October 1988 to September 2005.

REMARKS.-- Numerous anthropogenic alterations within basin (highly altered).

Averaged consecutive seven-day minimum discharge, in cubic feet per second, and indicated recurrence interval

2-year recurrence interval

47.4 10-year recurrence interval

34.8

Averaged consecutive seven-day minimum discharge, in cubic feet per second, and 10-year recurrence interval

\section{November-April}

32.9
November-December

42.4
January-February

48.3
March-April

36.2

Averaged consecutive seven-day minimum discharge, in cubic feet per second, and 10-year recurrence interval

\begin{tabular}{cccccc} 
November & December & January & February & March & April \\
41.8 & 48.7 & 51.0 & 51.0 & 49.3 & 38.9 \\
\hline
\end{tabular}




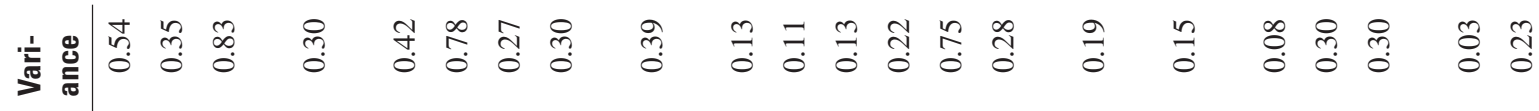

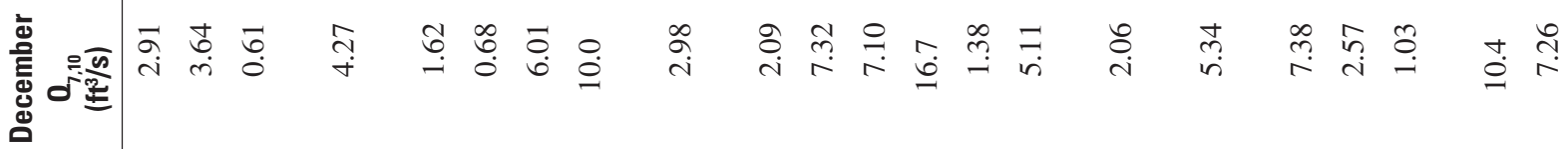

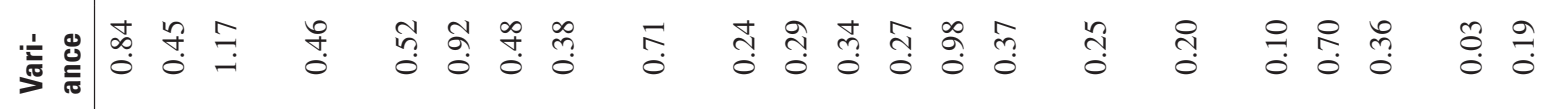
咅

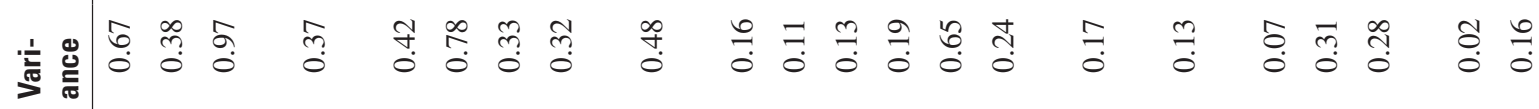
竞

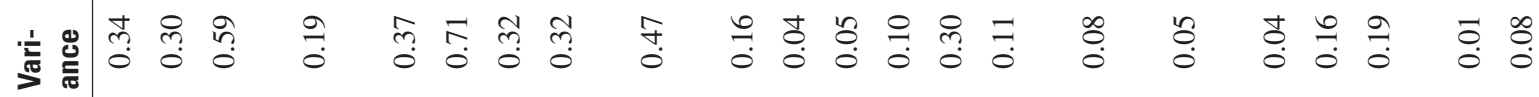
爱

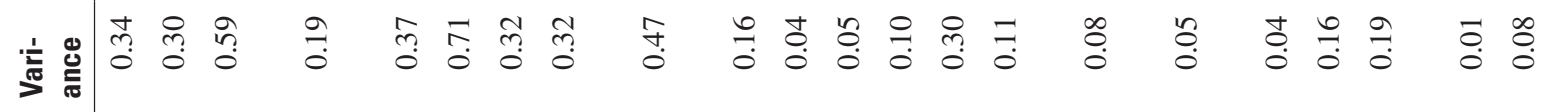

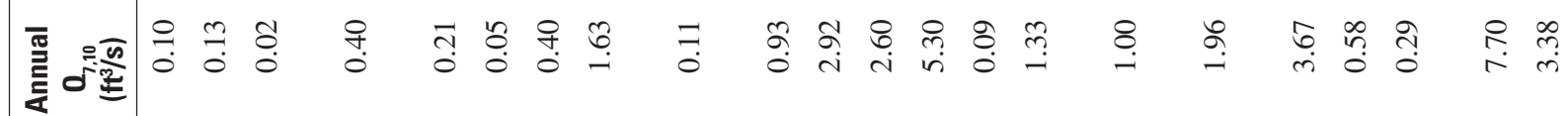

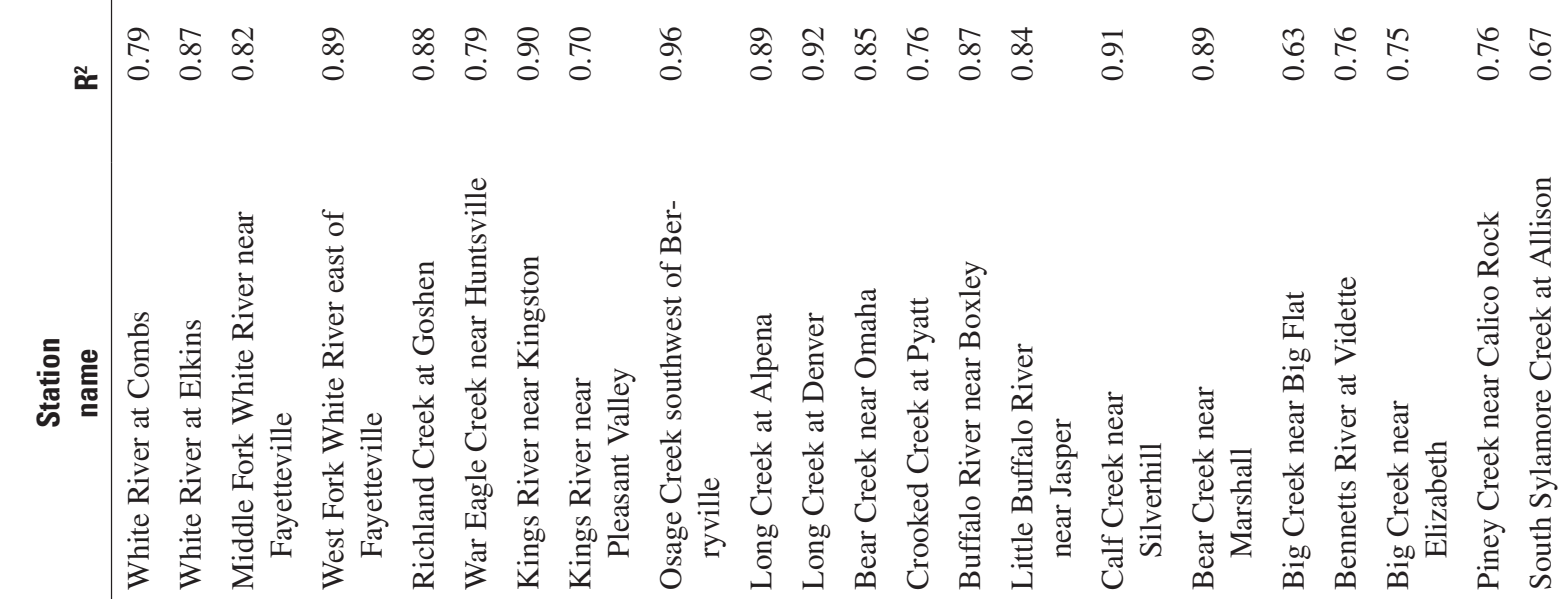

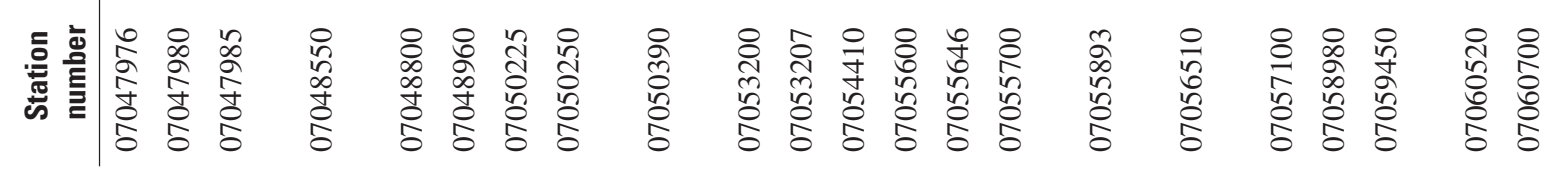




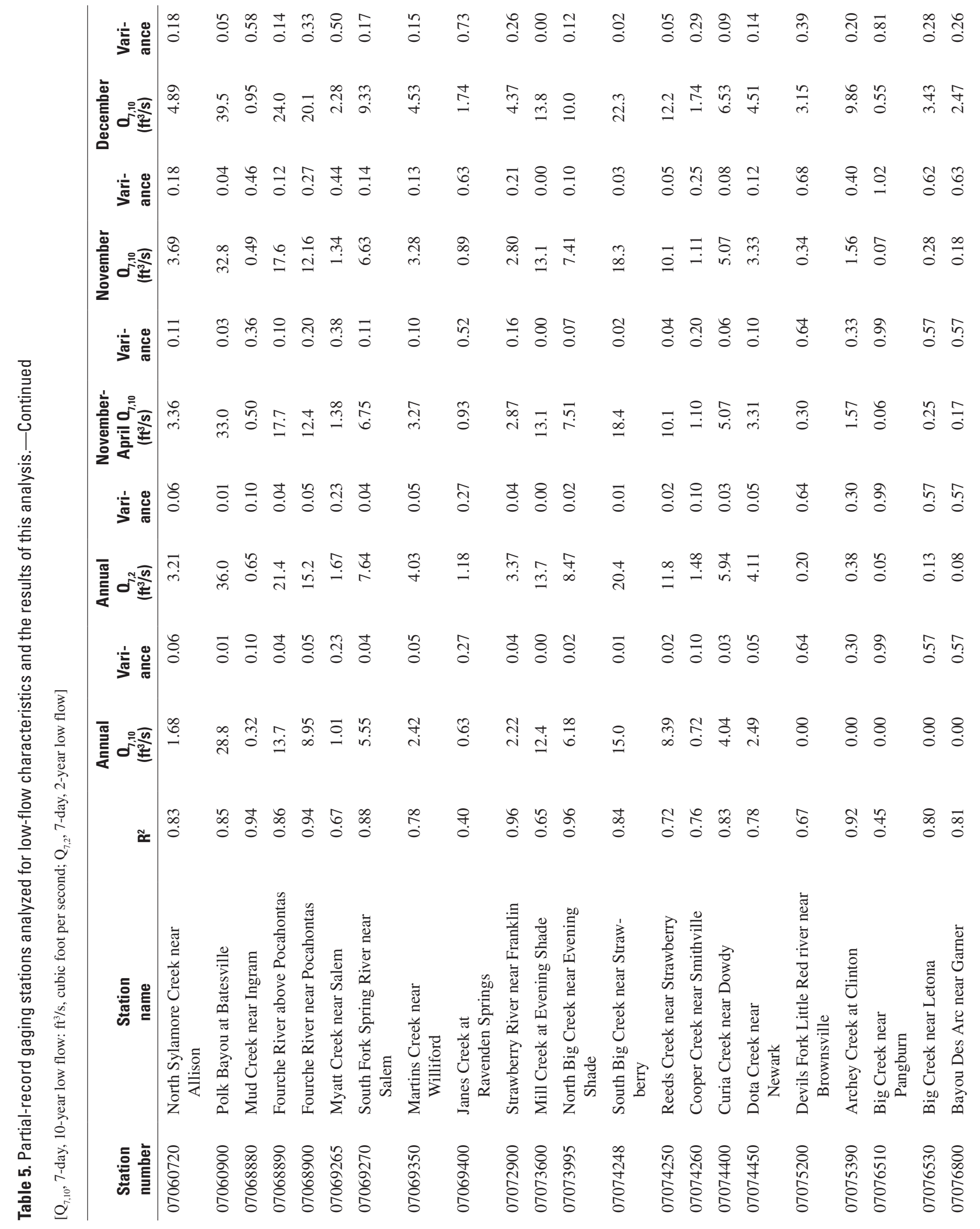




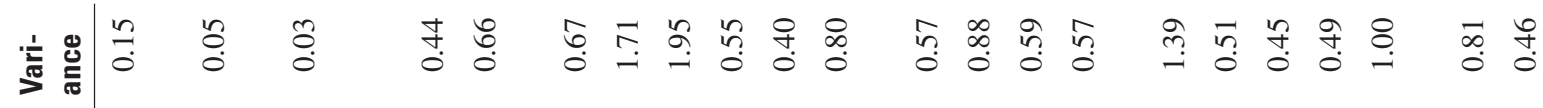
离

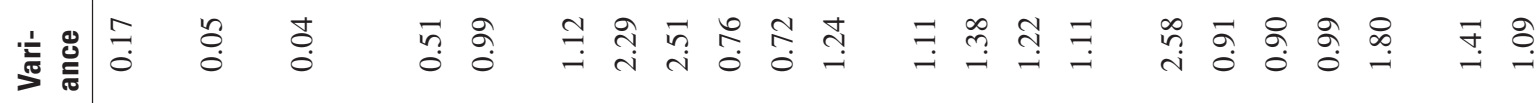
产

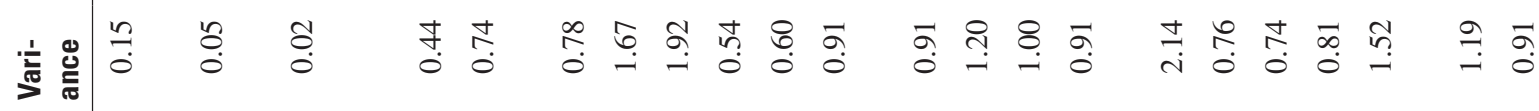
离

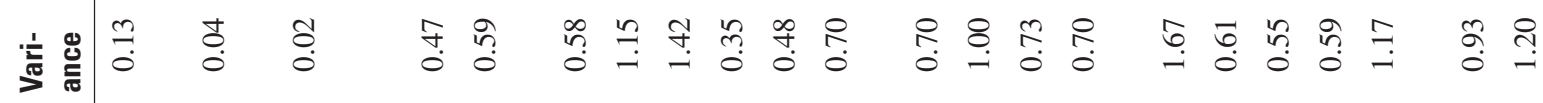

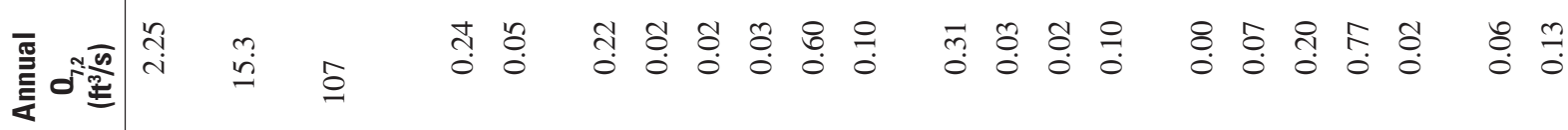

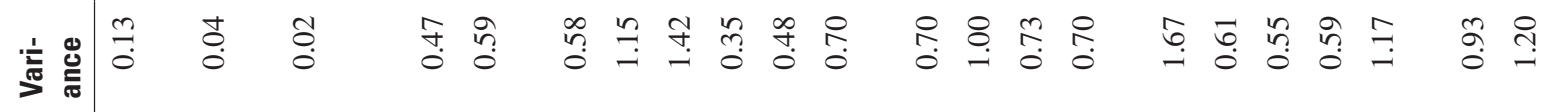
丝

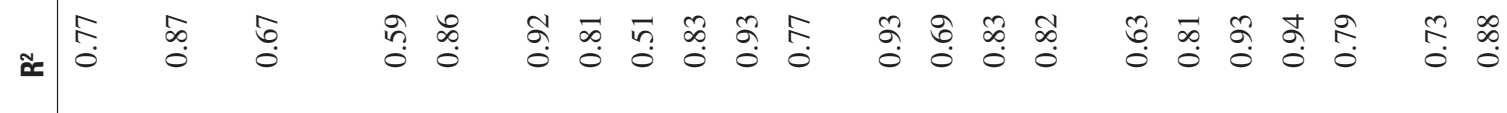

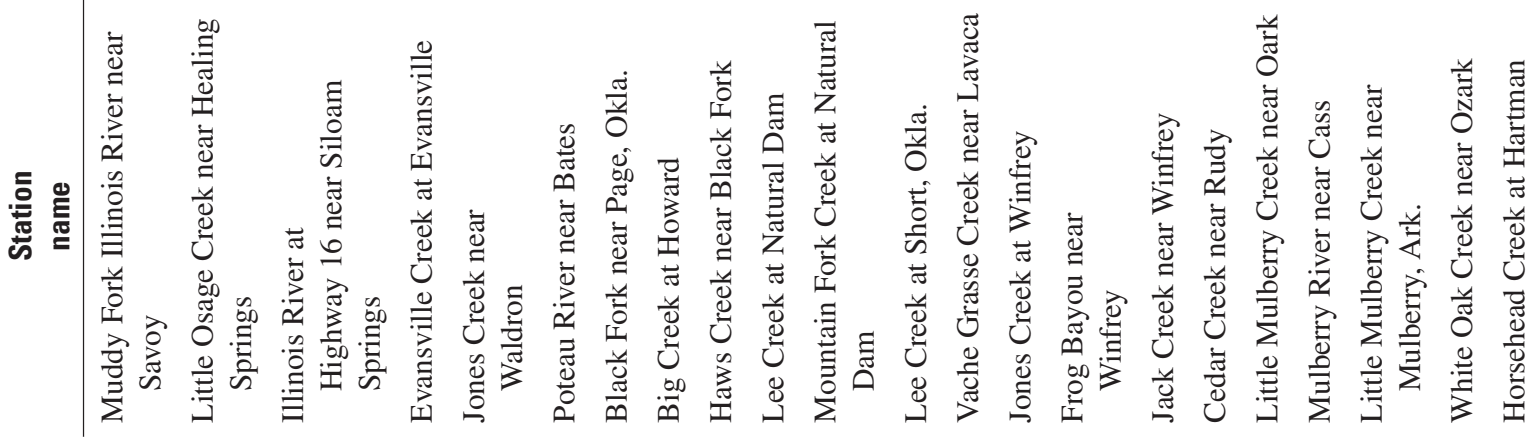

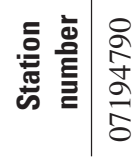

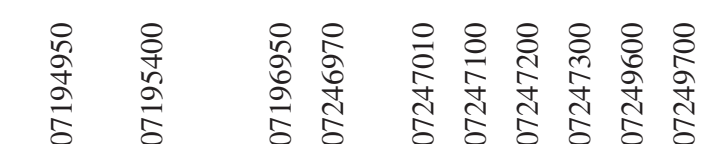

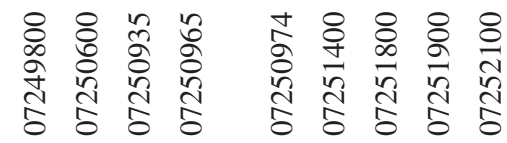




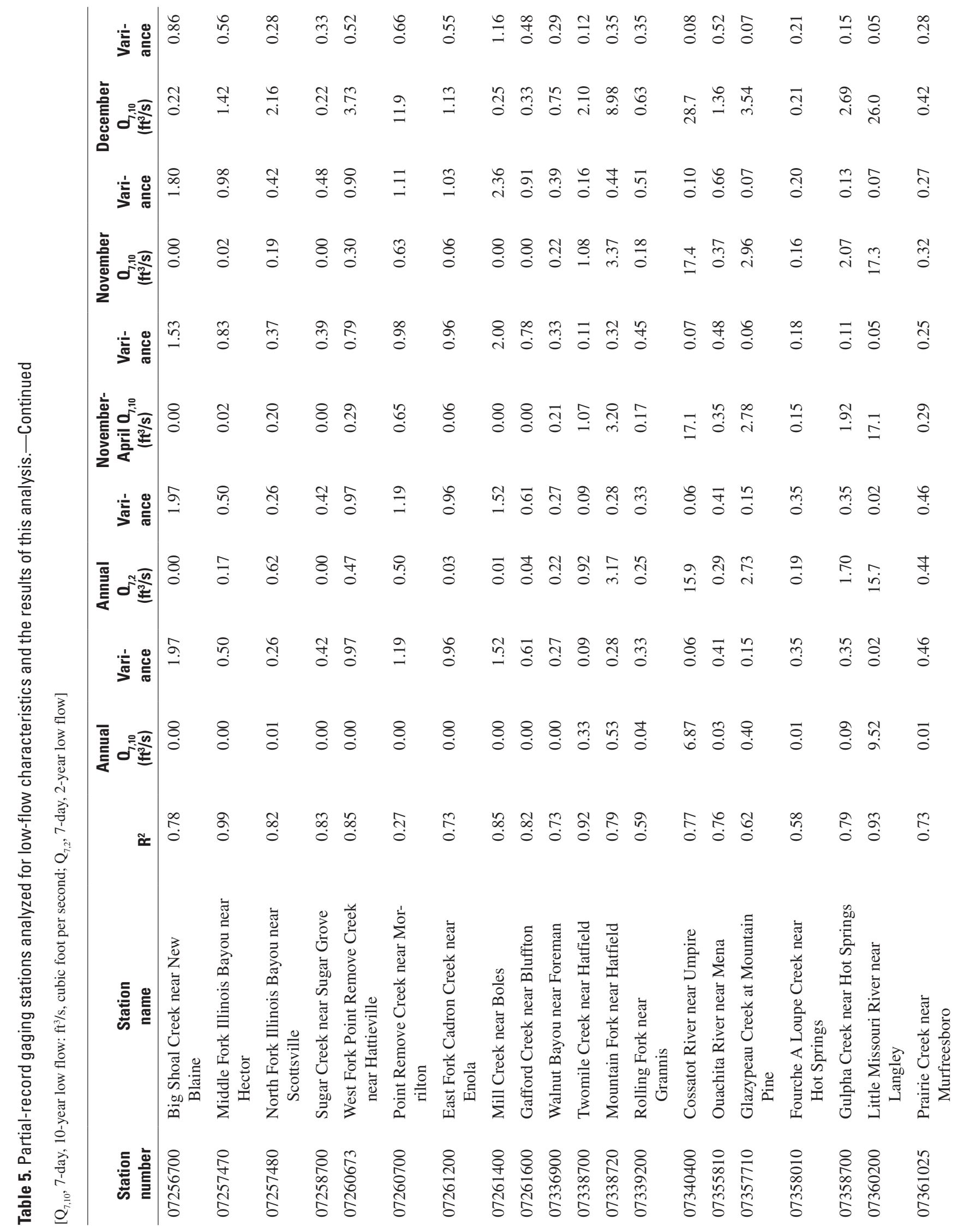


紊

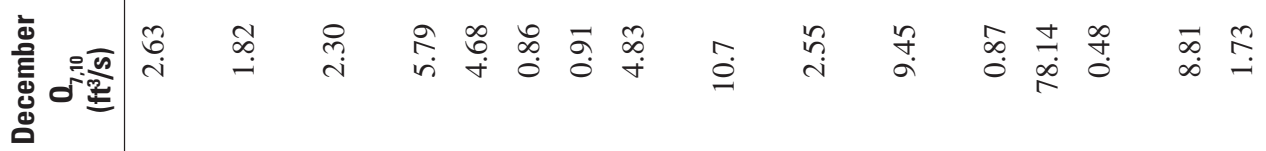

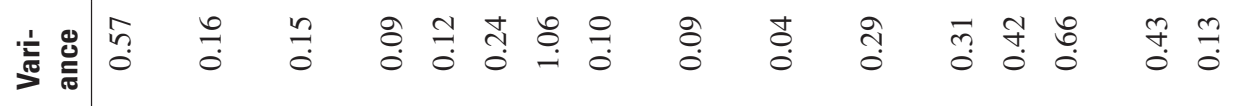
咅

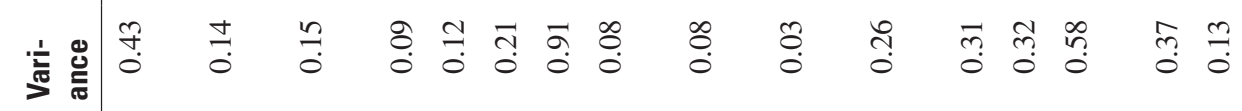

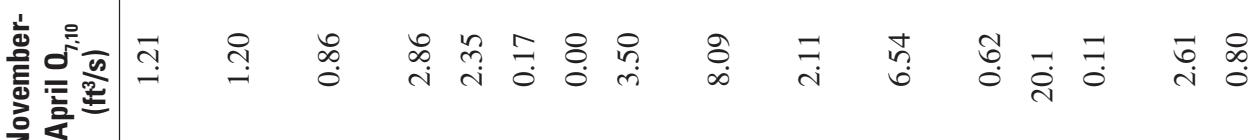

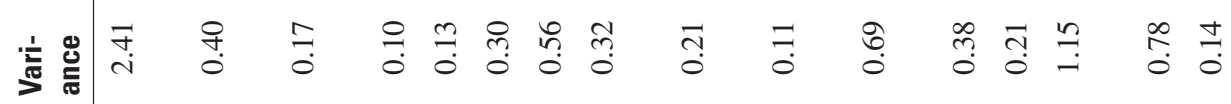

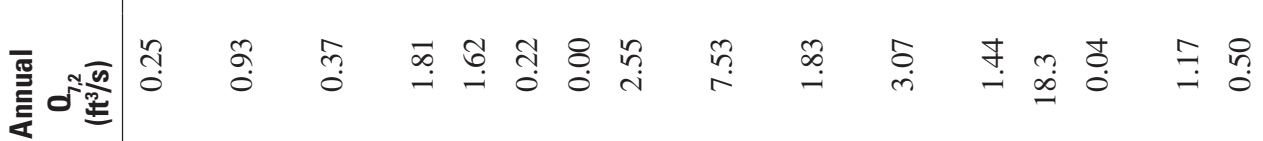

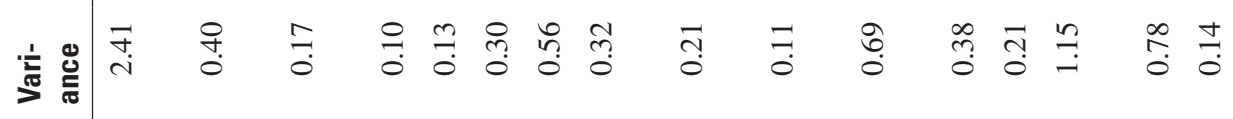

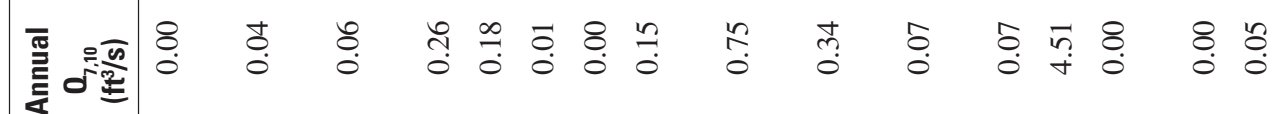

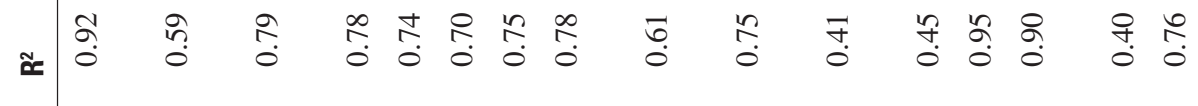

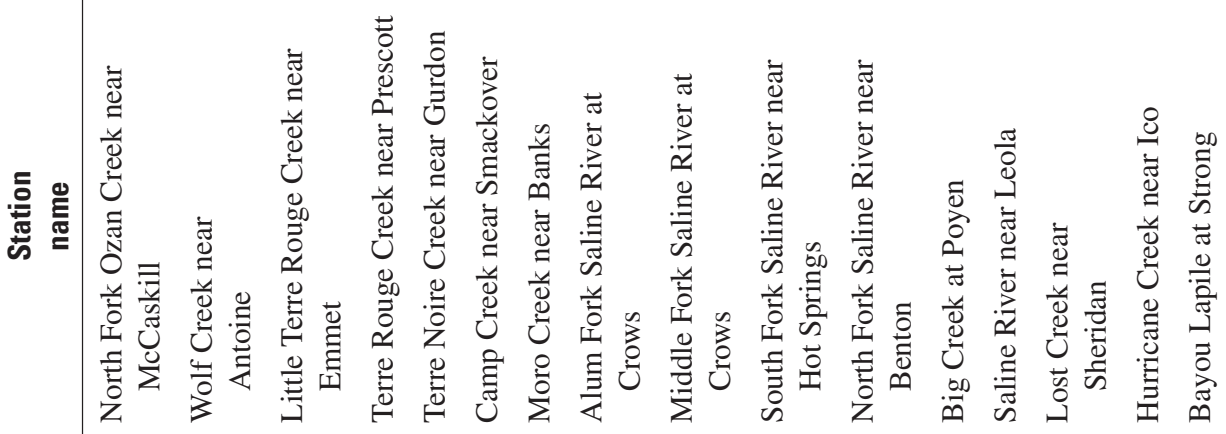

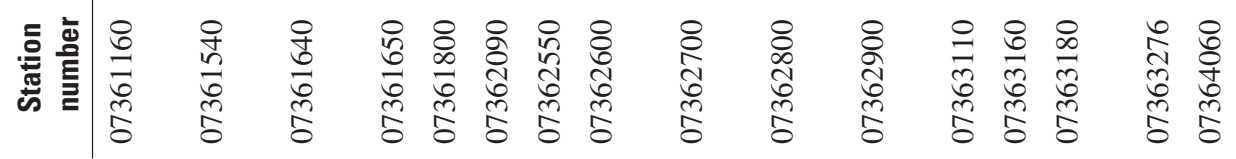




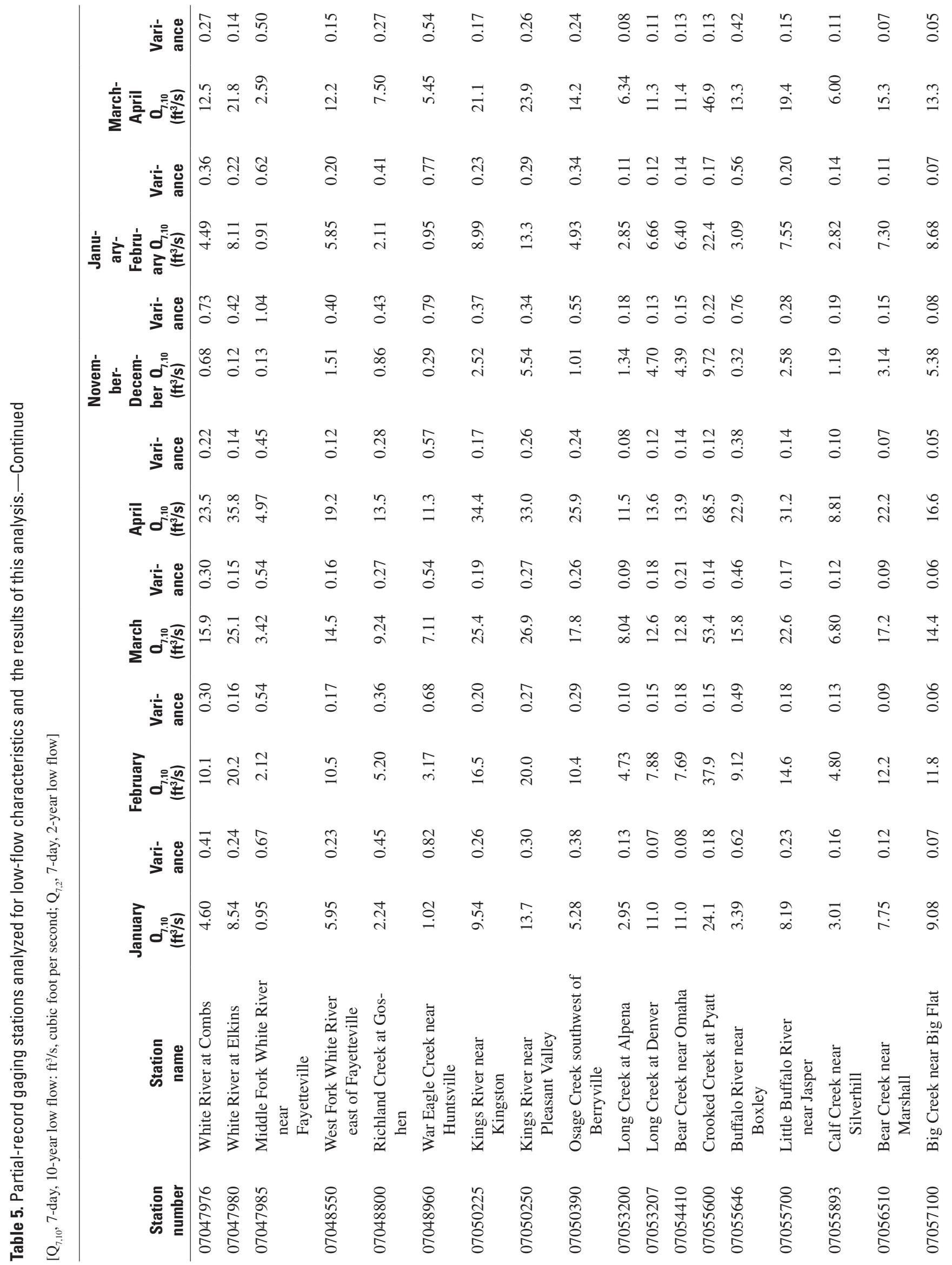




\begin{tabular}{|c|c|c|c|c|c|c|c|c|c|c|c|c|c|c|c|c|c|}
\hline 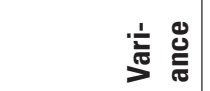 & $\bar{\sigma}$ & กิ & $\stackrel{\sigma}{0}$ & $\frac{n}{0}$ & $\stackrel{\infty}{0}$ & $\stackrel{0}{0}$ & $\bar{m}$ & $\stackrel{o}{0}$ & $\stackrel{\infty}{0}$ & $\ddot{n}$ & $\stackrel{0}{0}$ & $\stackrel{\circ}{\circ}$ & $\stackrel{\infty}{+}$ & $\stackrel{ \pm}{0}$ & $\stackrel{8}{0}$ & $\stackrel{0}{0}$ & $\overline{0}$ \\
\hline 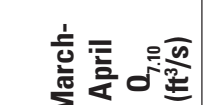 & 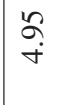 & $\stackrel{\Delta}{i}$ & $\stackrel{ \pm}{n}$ & $\stackrel{\check{2}}{2}$ & $\stackrel{5}{0}$ & $\begin{array}{l}o \\
\dot{0}\end{array}$ & $\begin{array}{l}+ \\
\dot{n}\end{array}$ & $\begin{array}{l}n \\
\stackrel{n}{n}\end{array}$ & $\stackrel{i}{\infty}$ & $\stackrel{n}{\alpha}$ & $\stackrel{\circ}{\stackrel{+}{d}}$ & $\stackrel{\Upsilon}{\varrho}$ & $\stackrel{\circ}{=}$ & $\stackrel{0}{i}$ & $\stackrel{\infty}{n}$ & $\hat{\mathrm{i}}$ & in \\
\hline 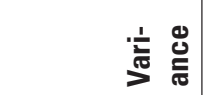 & $\tilde{n}$ & ֻึ & $\stackrel{0}{0}$ & तิ & $\stackrel{ \pm}{0}$ & 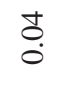 & f. & $\stackrel{2}{0}$ & $\tilde{y}$ & $\stackrel{J}{ \pm}$ & $\frac{ \pm}{0}$ & $\stackrel{m}{0}$ & $\stackrel{t}{0}$ & สิ & $\stackrel{8}{0}$ & $\stackrel{0}{\circ}$ & ठ̊. \\
\hline 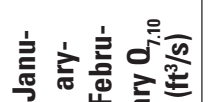 & त̂̃ & $\stackrel{m}{-}$ & $\stackrel{ \pm}{=}$ & $\frac{0}{a}$ & f & $\begin{array}{l}0 \\
\stackrel{+}{+}\end{array}$ & $\stackrel{\infty}{\leftrightarrow}$ & तें & $\underset{\infty}{\tilde{N}}$ & ते & $\stackrel{\infty}{=}$ & in & $\stackrel{\substack{i \\
i}}{i}$ & $\stackrel{n}{n}$ & $\stackrel{m}{ \pm}$ & $\stackrel{m}{\simeq}$ & $\stackrel{a}{\dot{d}}$ \\
\hline 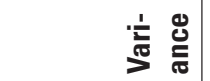 & 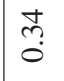 & @ి & $\stackrel{0}{0}$ & $\stackrel{5}{0}$ & $\stackrel{ \pm}{0}$ & $\stackrel{0}{0}$ & $\vec{J}$ & $\overrightarrow{0}$ & $\stackrel{\overbrace{}}{0}$ & $\stackrel{?}{0}$ & $\stackrel{1}{0}$ & $\stackrel{1}{0}$ & $n$ & $\stackrel{2}{0}$ & $\stackrel{8}{\circ}$ & $\stackrel{\infty}{\circ}$ & 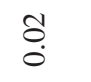 \\
\hline 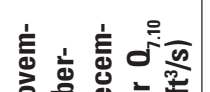 & $\stackrel{m}{m}$ & $\stackrel{8}{0}$ & $\begin{array}{l}\infty \\
\infty \\
\infty\end{array}$ & $\begin{array}{l}\infty \\
\stackrel{\infty}{+} \\
\dot{+}\end{array}$ & n. & $\begin{array}{l}\infty \\
i \\
m\end{array}$ & ఫे & $\stackrel{0}{\underline{I}}$ & $\stackrel{\widetilde{I}}{\mathrm{I}}$ & $\stackrel{m}{\leftrightarrow}$ & $\overbrace{0}^{\circ}$ & $\begin{array}{l}\stackrel{\sim}{n} \\
\text { ri }\end{array}$ & $\stackrel{8}{\circ}$ & $\begin{array}{l}\widetilde{N} \\
\text { i } \\
i\end{array}$ & $\vec{m}$ & $\underset{r}{\stackrel{7}{r}}$ & 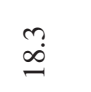 \\
\hline 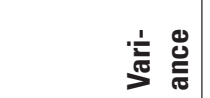 & $\tilde{3}$ & $\tilde{\widetilde{o}}$ & $\stackrel{0}{0}$ & $\stackrel{5}{0}$ & तิ & $\hat{o}$ & $\stackrel{\infty}{\tilde{0}}$ & $\stackrel{0}{0}$ & กิ & ले. & $\stackrel{1}{0}$ & $=$ & $n$ & $\stackrel{\infty}{0}$ & $\stackrel{8}{0}$ & $\stackrel{\infty}{0}$ & $\ddot{0}$ \\
\hline 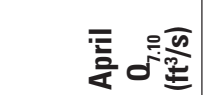 & 恶 & $\stackrel{\overrightarrow{+}}{+}$ & $\vec{I}$ & : & $\vec{m}$ & $\stackrel{\infty}{i}$ & $\underset{\infty}{\stackrel{2}{\infty}}$ & $\overrightarrow{5}$ & $\stackrel{\infty}{\varrho}$ & 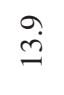 & $\begin{array}{l}\infty \\
\ddot{\lambda}\end{array}$ & $\begin{array}{l}0 \\
\stackrel{I}{C}\end{array}$ & $\hat{\sigma}$ & $\ddot{a}$ & $\stackrel{+}{\sigma}$ & $\stackrel{\infty}{\stackrel{\sim}{\sim}}$ & $\frac{n}{n}$ \\
\hline 㓍 & to & $\tilde{\overbrace{}}$ & $\stackrel{0}{0}$ & $\frac{5}{0}$ & ปิ & $\stackrel{\dddot{m}}{0}$ & $\stackrel{\infty}{n}$ & $\begin{array}{l}\circ \\
0\end{array}$ & กิ & ले & $\stackrel{1}{0}$ & $=$ & $n$ & $\stackrel{\infty}{0}$ & $\stackrel{8}{0}$ & $\stackrel{\infty}{\circ}$ & $\stackrel{\square}{0}$ \\
\hline 可 & 8 & $\frac{n}{n}$ & $\hat{\sigma}$ & $\stackrel{+}{\dot{d}}$ & $\stackrel{2}{\varrho}$ & $\vec{i}$ & $\begin{array}{l}n \\
i n \\
\infty \\
\infty\end{array}$ & $\hat{z}$ & 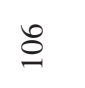 & $\stackrel{\bullet}{\stackrel{0}{\longrightarrow}}$ & $\stackrel{\text { ̀े }}{\text { aे }}$ & 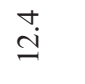 & 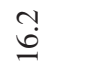 & $\stackrel{n}{2}$ & $\underset{\sigma}{+}$ & $\stackrel{+}{\stackrel{\Delta}{~}}$ & $\stackrel{\stackrel{\sim}{m}}{\stackrel{m}{*}}$ \\
\hline 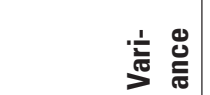 & 导 & $\stackrel{+}{3}$ & $\stackrel{\leftrightarrow}{0}$ & तิ & $\stackrel{0}{0}$ & $\stackrel{t}{0}$ & $\stackrel{\infty}{+}$ & $\stackrel{2}{0}$ & 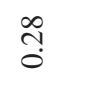 & In & $\stackrel{ \pm}{0}$ & $\stackrel{m}{0}$ & $\stackrel{n}{0}$ & กี & $\stackrel{8}{0}$ & $\stackrel{0}{3}$ & Oे \\
\hline 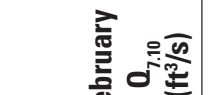 & $\overline{\widehat{i}}$ & 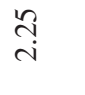 & $\stackrel{+}{ \pm}$ & $\stackrel{+}{\dot{\theta}}$ & ñ. & $\begin{array}{l}\circ \\
\text { in }\end{array}$ & 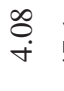 & $\vec{z}$ & $\ddot{8}$ & $\stackrel{\text { qn }}{r}$ & $\stackrel{\leftrightarrow}{\circ}$ & $\vec{a}$ & $\underset{r}{n}$ & $\stackrel{\infty}{=}$ & $\underline{n}$ & $\stackrel{\circ}{\circ}$ & ָֻ \\
\hline 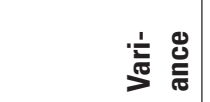 & กิ & ָิ & $\stackrel{t}{0}$ & $\stackrel{\tilde{o}}{0}$ & $\stackrel{5}{0}$ & $\stackrel{n}{0}$ & ñ & $\frac{n}{0}$ & mे. & in & $\stackrel{5}{0}$ & $\stackrel{n}{0}$ & $\stackrel{n}{\mathfrak{0}}$ & $\grave{\Im}$ & $\stackrel{8}{0}$ & $\stackrel{1}{0}$ & $\stackrel{0}{0}$ \\
\hline 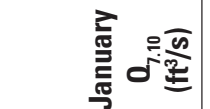 & $\underset{f}{\stackrel{f}{f}}$ & $\stackrel{\text { fo }}{-}$ & $\stackrel{\infty}{=}$ & बे & $\stackrel{R}{i n}$ & $\vec{b}$ & : & $\frac{\stackrel{n}{m}}{m}$ & $\hat{i}$ & n़े & $\stackrel{n}{\mathrm{I}}$ & 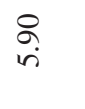 & ڤ్. & लु. & $\stackrel{n}{ \pm}$ & $\stackrel{0}{\ddot{g}}$ & $\ddot{n}$ \\
\hline 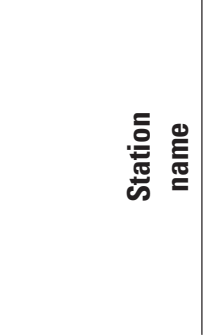 & 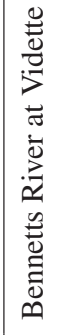 & 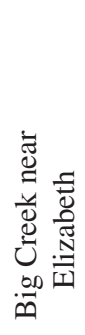 & 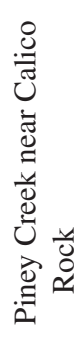 & 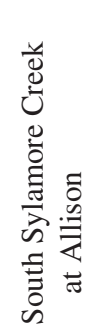 & 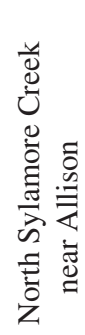 & 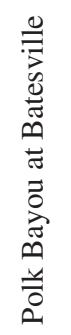 & 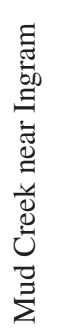 & 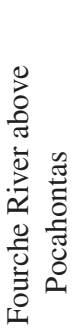 & 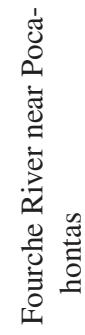 & 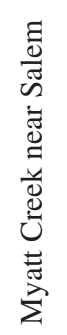 & 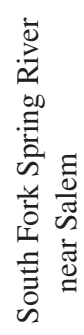 & 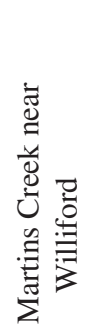 & 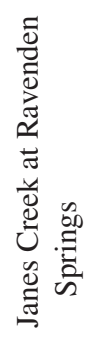 & 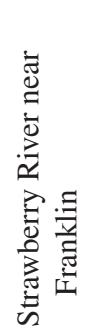 & 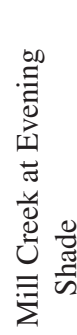 & 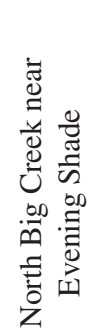 & 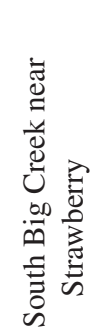 \\
\hline 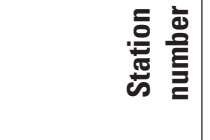 & $\begin{array}{l}\infty \\
\infty \\
\infty \\
\infty \\
2 \\
\vdots \\
0\end{array}$ & 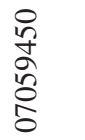 & 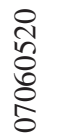 & $\begin{array}{l}8 \\
8 \\
0 \\
0 \\
\vdots \\
0\end{array}$ & 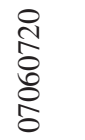 & $\begin{array}{l}8 \\
8 \\
8 \\
8 \\
8 \\
0\end{array}$ & $\begin{array}{l}\stackrel{0}{ } \\
\infty \\
\infty \\
\stackrel{0}{0} \\
\vdots \\
0\end{array}$ & 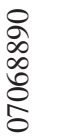 & $\begin{array}{l}8 \\
\& \\
\infty \\
\& \\
\stackrel{8}{0} \\
0\end{array}$ & 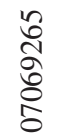 & 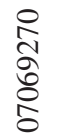 & 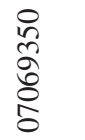 & 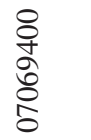 & 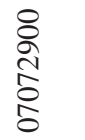 & 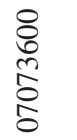 & 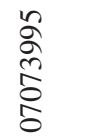 & 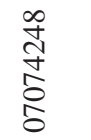 \\
\hline
\end{tabular}




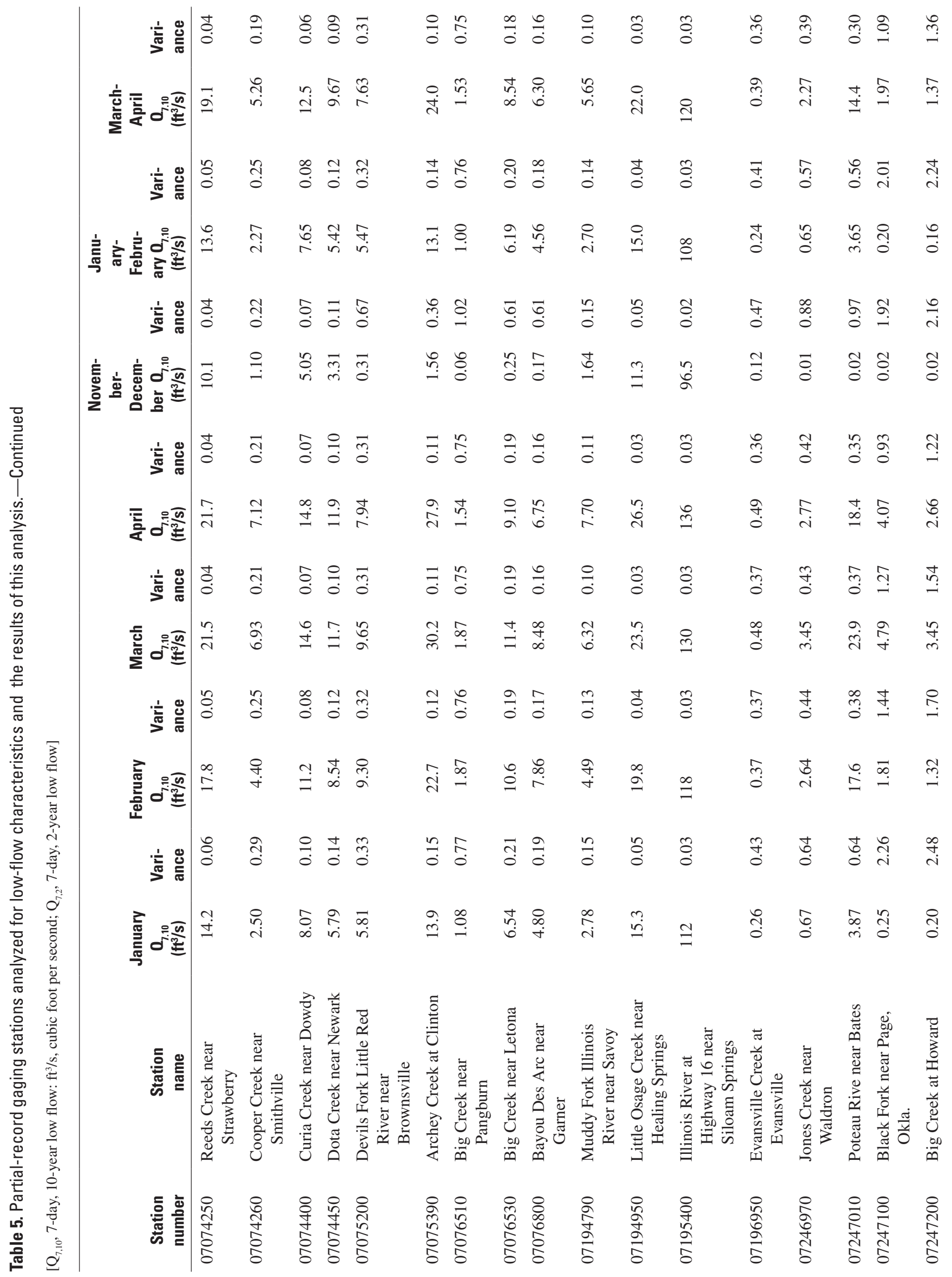




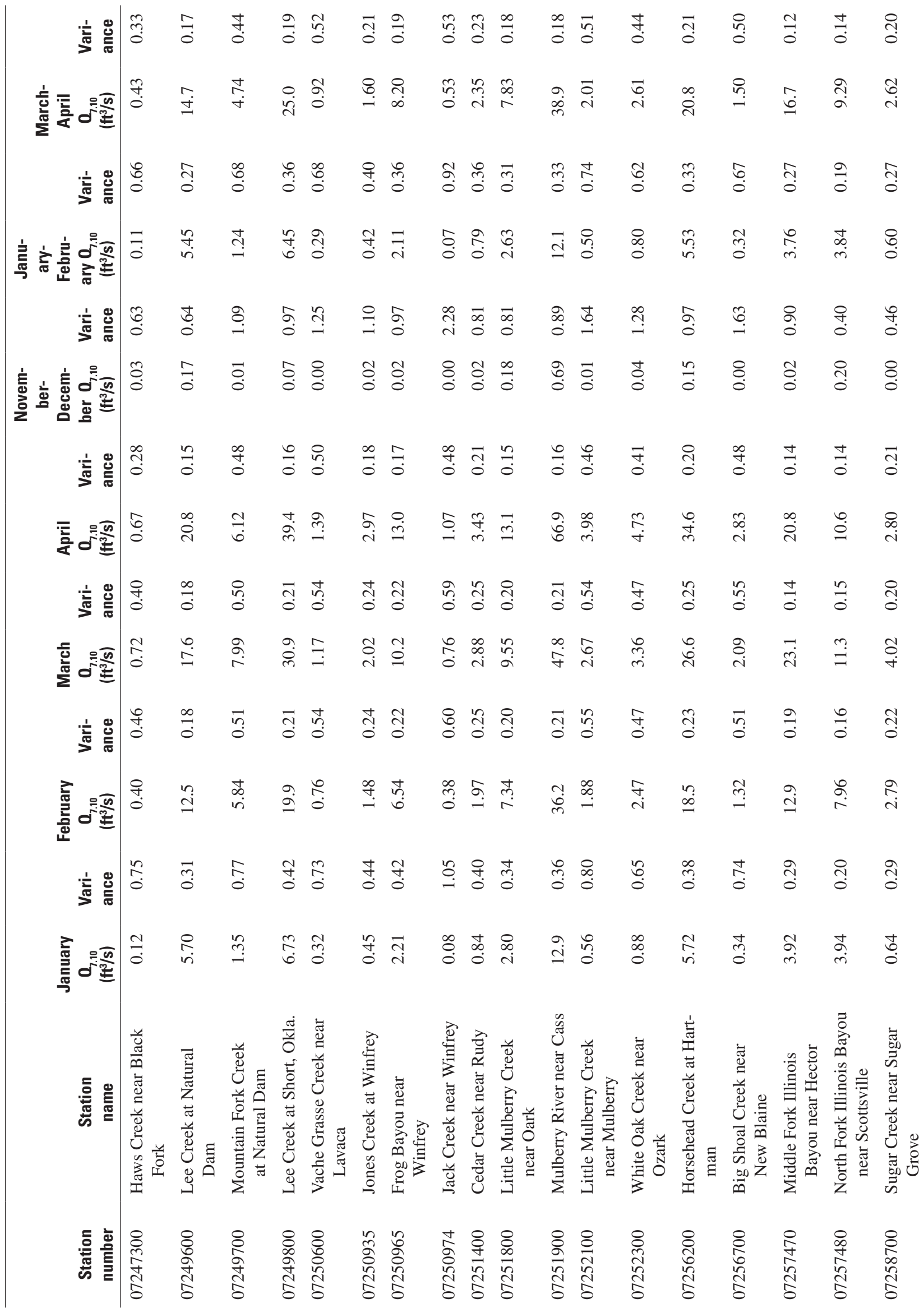




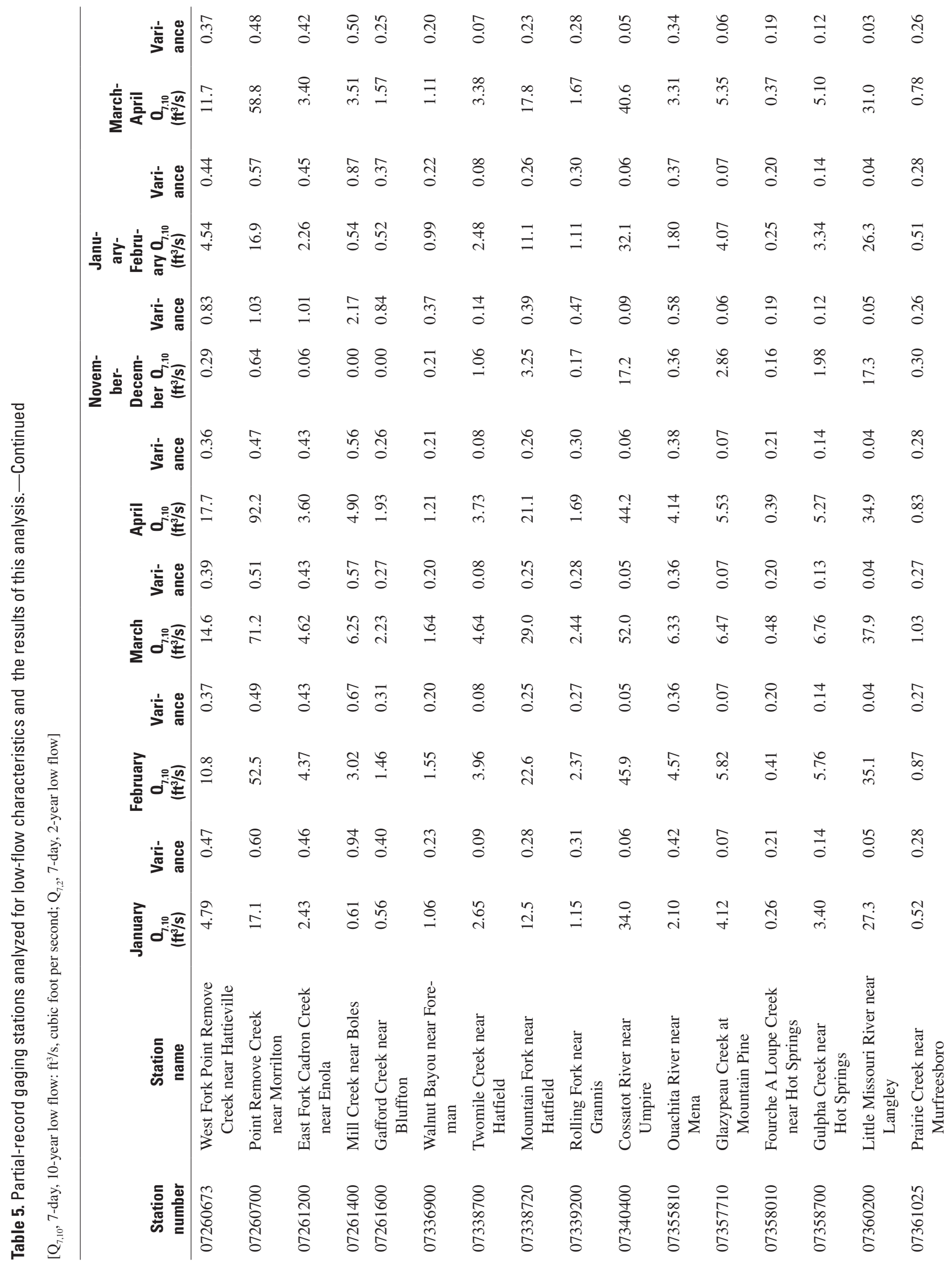




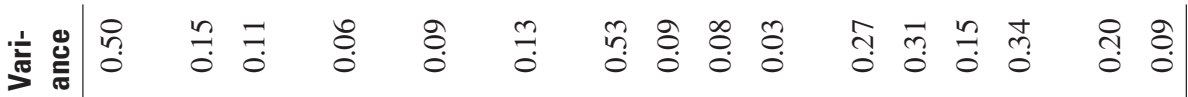

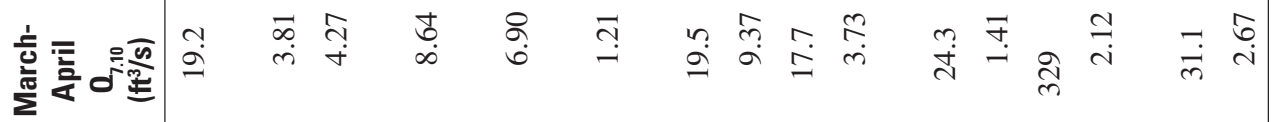

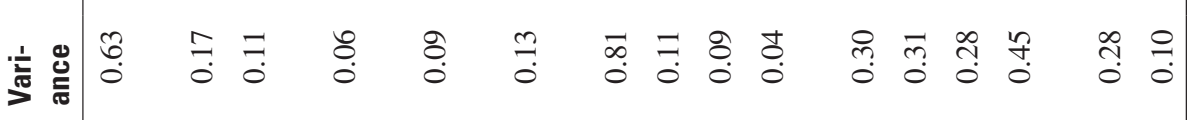

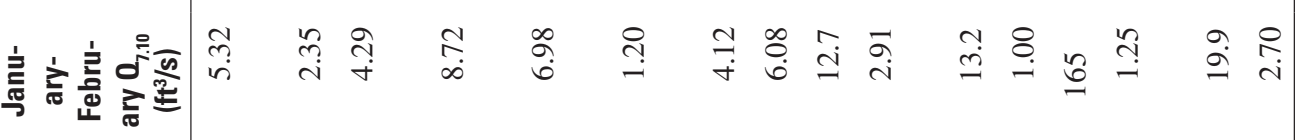

立

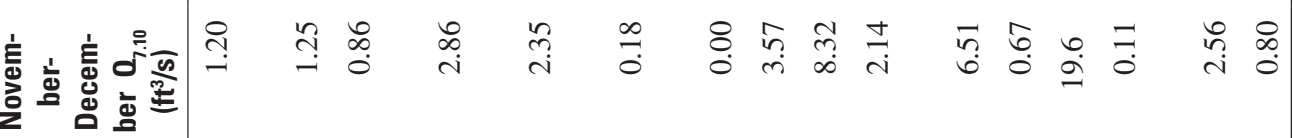

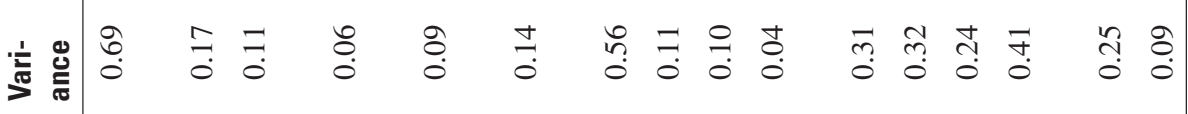

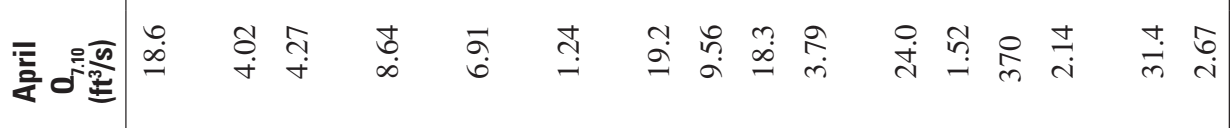

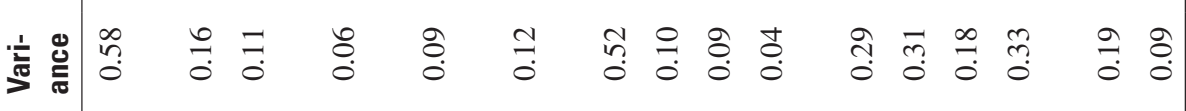
䎡

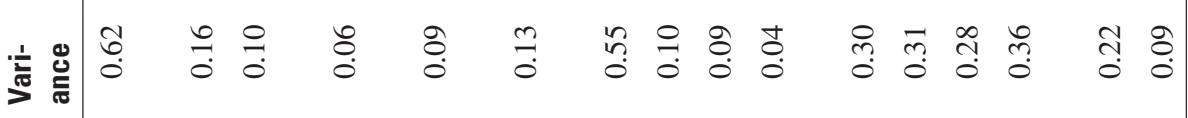

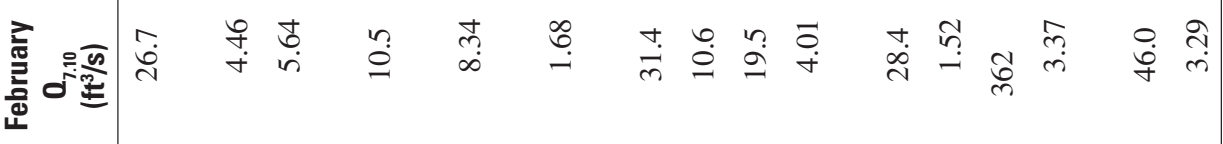
紊

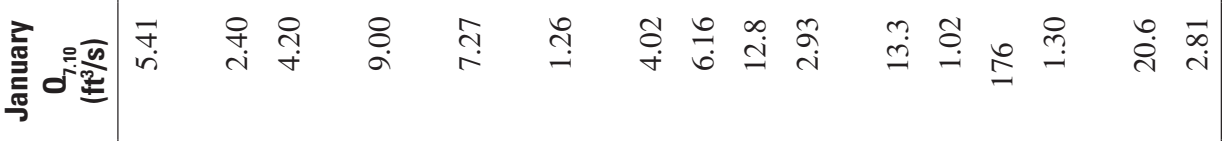

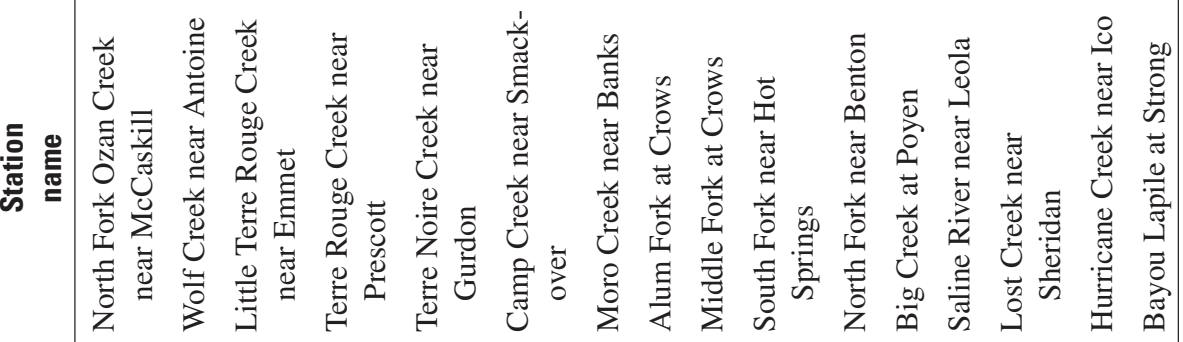

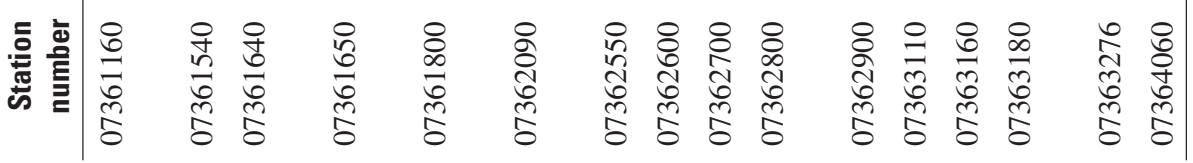




\section{Appendixes 1-4}




\section{Appendix 1. Description of Base-Flow Correlation Method}

The Stedinger and Thomas (1985) method, or base-flow correlation method, estimates low-flow characteristics by using the mean and standard deviation of the time series of 7-day low flows at the partial-record station given by

$$
\log _{10}\left(Q_{7,10}\right)=\hat{\mu}_{p}+K \hat{\sigma}_{p}
$$

where

$$
\begin{gathered}
\hat{\mu}_{p} \quad \begin{array}{l}
\text { is the estimate of the mean of the time series } \\
\text { of the 7-day low flows at the partial record } \\
\text { gage, }
\end{array} \\
\hat{\sigma}_{p} \quad \text { is the estimate of the standard deviation of the } \\
\text { time series of the 7-day low flows at the } \\
\text { partial-record gage, and } \\
K \quad \text { is the log-Pearson Type III standard deviate } \\
\text { for a recurrence interval of } T \text {-years at the } \\
\text { partial-record gage. }
\end{gathered}
$$

By assuming that the time series of the 7-day low flows are log-Pearson Type III distributed at both the index and partialrecord gages with equal skew coefficients, the $K$ is estimated by the log-Pearson Type III standard deviate at the index gage, $K_{\mathrm{i}}$. The $\hat{\mu}_{p}$ and $\hat{\sigma}_{p}$ are

$$
\begin{gathered}
\hat{\mu}_{p}=\beta_{o}+\beta_{1} m_{i} \\
\hat{\sigma}_{p}=\left\{\beta_{1}^{2} s_{i}^{2}+s_{e}^{2}\left[1-\frac{s_{i}^{2}}{\left(n_{b}-1\right) s_{c}^{2}}\right]\right\}^{1 / 2}
\end{gathered}
$$

where

$$
\begin{aligned}
& m_{i} \quad \text { is the mean of the time series of the 7-day low } \\
& s_{i}^{2} \quad \text { flows at the index gage, } \\
& \text { is the variance of the time series of the 7-day }
\end{aligned}
$$

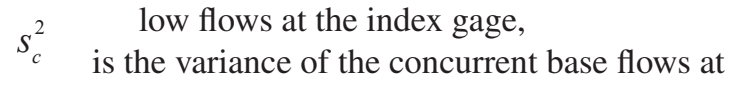

$$
\begin{aligned}
& \text { the index gages, } \\
& n_{b} \quad \text { is the number of base-flow measurements at } \\
& \text { the partial-record gage, } \\
& \beta_{o} \text { and } \beta_{1} \text { are the constant and coefficient of a } \\
& \text { regression among concurrent flows at the } \\
& s_{e}^{2} \quad \text { partial-record and index gages, and } \\
& \text { is the squared standard error from the } \\
& \text { regression among concurrent flows. }
\end{aligned}
$$

This approach is dependent on the number of available base-flow discharge measurements at the partial-record gage. Having anything less than about 10 base-flow discharge measurements (U.S. Geological Survey, 1985) at the partialrecord gage will result in unreliable estimates of $\beta_{0}, \beta_{1}$ and $s_{e}^{2}$, because they are calculated from a regression model. In this study, the base-flow correlation approach was not applied when less than 10 base-flow measurements were available at the partial-record station. 


\section{Appendix 2. Regional Regression Models}

The parameters of the logistic regression model are estimated by maximizing the log likelihood function given by:

$$
L(\beta)=\sum_{i=1}^{n}\left\{y_{i} \ln \left[\frac{e^{g(x)}}{1+e^{(x)}}\right]+\left(1-y_{i}\right) \ln \left[1-\frac{e^{g(x)}}{1+e^{g(x)}}\right]\right.
$$

and

$$
\begin{aligned}
& g(x)=\hat{\beta}_{0}+\hat{\beta}_{1} \log _{10}\left(x_{1}\right)+ \\
& \hat{\beta}_{2} \log _{10}\left(x_{2}\right)+\ldots+\hat{\beta}_{k} \log _{10}\left(x_{k}\right)
\end{aligned}
$$

where

$$
\begin{gathered}
n \quad \begin{array}{c}
\text { is the total number of annual events at all } \\
\text { sites, }
\end{array} \\
y_{i} \quad \begin{array}{c}
\text { is equal to one if an observed annual } d \text {-day } \\
\text { low flow is not zero in year } i, \text { and }
\end{array} \\
y_{i} \quad \begin{array}{c}
\text { is equal to zero if an observed annual } d \text {-day } \\
\text { low flow is zero, }
\end{array} \\
x_{k} \quad \text { is the value of the } \mathrm{k}^{\text {th }} \text { basin attribute. }
\end{gathered}
$$

The treatment of partial-record gaging stations in the logistic regression models was to assign a value of $y_{i}$ (in equation 2-1) equal to one if the date of the measured base-flow value fell within the time period of interest for every climatic year, $i$ (April 1 to March 31). Otherwise, the value of $y_{i}$ was zero for partial-record sites that did not have measurements during the period of interest in every climatic year, $i$. For every climatic year, the value of $y_{i}$ was set equal to one. The assumption was that the measured base-flow values were the lowest for the period of interest for every climatic year considered.

If the total number of zero events for any chosen annual series was less than 5 percent of the observed events equal to zero, then a logistic regression was not formed. For regions that did not meet the 5 percent criteria, the statewide regression (see Low-Flow Characteristics at Ungaged Basins section of the report for explanation) was used for the region specific logistic regression model if at least 5 percent of observed events equaled zero.

The general relation between the logarithmic (base 10) transforms of the peak discharges and basin attributes in the regression model can be given by

$$
\begin{aligned}
& \log _{10}\left(Q_{d-\text { day }, T-\text { year }}\right)=\beta_{o}+\beta_{1} \log _{10}\left(x_{1}\right) \\
& +\ldots+\beta_{k} \log _{10}\left(x_{k}\right)+\delta
\end{aligned}
$$

$$
\begin{aligned}
& Q_{d-d a y, T-y e a r} \quad \text { is the } d \text {-day, } T \text {-year low flow, } \\
& \text { is the number of basin attributes, and } \\
& \delta \quad \text { is the model error with mean equal to zero } \\
& \text { and variance equal to } \delta_{\delta}^{2} \text {. }
\end{aligned}
$$

The streamflow record at continuous-record streamflow gaging stations can be used to estimate $\log _{10}\left(Q_{d-d a y, T \text {-year }}\right)$ values for use in equation (2-3), referred to as $\log _{10}\left(\hat{Q}_{d-\text { day }, T-\text { year }}\right)$. The difference between the estimated and $\log _{10}\left(Q_{d-d a y, T-\text {-year }}\right)$ is known as the time sampling error, $\eta$, given as

$$
\eta=\log _{10}\left(\hat{Q}_{d-d a y, T-\text { year }}\right)-\log _{10}\left(Q_{d-\text { day }, T-\text { year }}\right)
$$

Substituting equation (2-4) into equation (2-3) give

$$
\begin{aligned}
& \eta=\log _{10}\left(\hat{Q}_{d-d a y, T-\text { year }}\right)=\beta_{0}+\beta_{1} \log _{10}\left(x_{k}\right) \\
& +\ldots+\beta_{k} \log _{10}\left(x_{k}\right)+v
\end{aligned}
$$

where

$$
v \text { is } \delta+\eta \text {. }
$$

Unlike generalized least squares parameter fitting (Stedinger and Tasker, 1985; Tasker and Stedinger, 1989), for weighted least squares (WLS) parameter fit, the time-sampling errors from basins close together are assumed not to be correlated (Tasker, 1980).

The estimates of the parameters in equation (2-5) were calculated using a WLS method. A vector of these parameter estimates, $\hat{\boldsymbol{\beta}}_{1}$, calculated by the WLS method, is given as

$$
\hat{\boldsymbol{\beta}}=\left(\mathbf{X}^{T} \hat{\mathbf{W}}^{-1} \mathbf{X}\right)^{-1} \mathbf{X}^{T} \hat{\mathbf{W}}^{-1} \hat{\mathbf{Y}}
$$

where

$\mathbf{X} \quad$ is a $(n \times(k+1))$ matrix augmented by a column of ones ( $n$ is equal to the number of basins in the regression model,

$\hat{\mathbf{Y}} \quad$ is a $(n \times 1)$ vector of $\left(\hat{Q}_{d-d a y, T-\text { year }}\right)$ values, and $\hat{\mathbf{W}}$ is a matrix containing the estimates of the weights on the main diagonal, while the off diagonal elements are all zero.

The weights contain a part associated with $\delta$ and $\eta$. Following Tasker (1980), $\hat{\mathbf{W}}$ is given as

$$
\hat{W}_{p q}=\left\{\begin{array}{cc}
\hat{c}_{0}+\hat{c}_{1}\left(\frac{1}{P O R}\right) & (p=q) \\
0 & (p \neq q)
\end{array}\right\}
$$


and

$$
\begin{gathered}
\hat{c}_{0}=\max \left[0, \hat{\sigma}_{\text {OLS }}^{2}-\hat{c}_{1}\left(\frac{1}{n} \sum_{i=1}^{n} \frac{1}{P O R_{i}}\right)\right] \\
\hat{c}_{1}=\max \left[0, \bar{s}^{2}\left(1+\frac{\bar{K}_{L P 3}^{2}}{2}\left(1+0.75 \bar{g}^{2}\right)+\bar{K}_{L P 3} \bar{g}\right)\right]
\end{gathered}
$$

where

$$
\begin{array}{cc}
\text { POR } & \text { is the number of complete climatic years } \\
& \text { (March 31 to April 1) of streamflow record } \\
& \text { at both types (continuous-streamflow } \\
& \text { record and partial-record) of gaged basins, } \\
n & \text { is the number of basins used in the regression } \\
& \text { model, } \\
\hat{\sigma}_{\text {OLS }}^{2} \quad \text { is the observed standard error of estimate } \\
\text { using OLS fitting, } \\
\bar{K}_{L P 3} \quad \text { is the arithmetic average of the log-Pearson } \\
\text { Type III deviates for all continuous- } \\
\text { streamflow record gaging stations used in } \\
\text { the regression model, } \\
\text { is the arithmetic average of the station skews } \\
\text { for all continuous-streamflow record } \\
\text { gaging stations used in the regression } \\
\text { model, and } \\
\text { is the arithmetic average of standard deviation } \\
\text { of the annual series of low flows estimated } \\
\text { by a sigma regression (Tasker and } \\
\text { Stedinger, 1989). }
\end{array}
$$

The sigma regression was formed from the standard deviations at continuous-streamflow record gaging stations and partial-record gaging stations and their associated basin attributes that were found to be statistically significant $(\mathrm{p}<0.05)$.

The use of the weights given by equation (2-7) is valid only for continuous-streamflow record gaging stations. When including partial-record gaging stations into the regression model, the weights computed must be modified. As described earlier, this study used the base-flow correlation method by Stedinger and Thomas (1985) to estimate the low-flow characteristics at the partial-record gaging stations. From this analysis, only an estimate of the variance was computed for each partial-record gaging station (table 5). In this method, the $K_{L P 3}$ and $g$ values at the partial-record gaging station are assumed to be the same as those at the index station selected. These assumptions also are extended to the graphical method. As can be seen from table 2-1, certain index stations were selected often while others were not selected at all. It is unwise to use the repeated $K_{L P 3}$ and $g$ values from the partial-record gaging stations to compute the $\bar{K}_{L P 3}$ and $\bar{g}$ values in equation (2-9), so only the continuous-streamflow record gaging stations were used to compute $\bar{K}_{L P 3}$ and $\bar{g}$ (table 2-1).
For the sigma regression, the standard deviation of the annual series of low flows from the continuous-streamflow record gaging stations and those from the partial-record stations were used. A simple approach was used in this study to estimate the $P O R$ for the partial-record stations. A value of 1 year was assigned for every year that base-flow discharge measurements were measured regardless of the number of discharge measurements observed that year. These values of one were summed and the total number was assumed to be the entire $P O R$ for each partial-record gaging station. This approach for partial-record stations was consistent with how the continuous-streamflow record gaging stations were treated, which assigned a value of one for each complete year of streamflow record.

The amount of variability accounted for by regression models is usually moderate, nearly 50 percent, so the model error typically tends to be much larger than the time-sampling error. This result suggests that an exact estimate of $P O R$ values for the partial-record stations will improve the estimation of the coefficients marginally. A previous study by Ries and Friesz (2000) concluded that the use of equivalent years of record for partial-record stations (Hardison and Moss, 1972) to determine a weight was a poor surrogate for the true value of the POR at a partial-record station. Ries and Friesz (2000) also considered that a year (counted within the $P O R$ ) can be assigned a value of greater than one for every year where multiple base-flow discharge measurements were observed, which was not explored in this study nor is it explained in this report. 
Table 2-1. Statistical summary of the coefficient values used in the regression models for each low-flow characteristics of interest.

$\left[\mathrm{Q}_{7,10}\right.$, 7-day, 10-year low flow; $\mathrm{Q}_{7,2}$, 7-day, 2-year low flow; **, Insufficient data for individual equation for region. The statewide equation is used for this calculation. --, no continuous streamflow-record gaging stations were compared from this model]

\begin{tabular}{|c|c|c|c|c|c|}
\hline $\begin{array}{c}\text { Low-flow } \\
\text { characteristic }\end{array}$ & $\begin{array}{l}\text { Standard error } \\
\text { of the model } \\
\text { (percent) }\end{array}$ & $\begin{array}{l}\text { Final number } \\
\text { of points in } \\
\text { regression }\end{array}$ & $\begin{array}{l}\text { Leverage } \\
\text { threshold } \\
\text { (d, h }{ }_{\text {limit }} \text { ) }\end{array}$ & $\begin{array}{l}\text { Number of } \\
\text { large } \\
\text { leverage } \\
\text { points }\end{array}$ & $\begin{array}{l}\text { Continuous- } \\
\text { streamflow } \\
\text { record gaging } \\
\text { stations removed }\end{array}$ \\
\hline \multicolumn{6}{|c|}{ Region 1} \\
\hline Annual $Q_{7,2}$ & 101.2 & 53 & 0.15 & 4 & 07195800,07073500 \\
\hline Annual $Q_{7,10}$ & 216.6 & 50 & 0.16 & 3 & 07195430,07073500 \\
\hline November-April $Q_{7,10}$ & 123.7 & 52 & 0.11 & 7 & 07055875 \\
\hline January-February $Q_{7,10}$ & 78.4 & 52 & 0.11 & 6 & 07055875 \\
\hline March-April $Q_{7,10}$ & 51.8 & 51 & 0.15 & 6 & 07055875,07195800 \\
\hline November $Q_{7,10}$ & 126.9 & 52 & 0.11 & 7 & 07055875 \\
\hline January $Q_{7,10}$ & 77.9 & 52 & 0.11 & 7 & 07055875 \\
\hline February $Q_{7,10}$ & 51.2 & 52 & 0.15 & 7 & 07195800 \\
\hline $\operatorname{March} Q_{7,10}$ & 55.4 & 52 & 0.11 & 7 & 07195800 \\
\hline April $Q_{7,10}$ & 52.5 & 52 & 0.11 & 7 & 07195800 \\
\hline
\end{tabular}


Table 2-1. Statistical summary of the coefficient values used in the regression models for each low-flow characteristics of interest.-Continued

$\left[\mathrm{Q}_{7,10}\right.$, 7-day, 10-year low flow; $\mathrm{Q}_{7,2}$, 7-day, 2-year low flow; **, Insufficient data for individual equation for region. The statewide equation is used for this calculation. --, no continuous streamflow-record gaging stations were compared from this model]

\begin{tabular}{|c|c|c|c|c|c|}
\hline $\begin{array}{c}\text { Low-flow } \\
\text { characteristic }\end{array}$ & $\begin{array}{l}\text { Standard error } \\
\text { of the model } \\
\text { (percent) }\end{array}$ & $\begin{array}{l}\text { Final number } \\
\text { of points in } \\
\text { regression }\end{array}$ & $\begin{array}{l}\text { Leverage } \\
\text { threshold }{ }^{1} \\
\left.\text { (d, } h_{\text {limit }}\right)\end{array}$ & $\begin{array}{l}\text { Number of } \\
\text { large } \\
\text { leverage } \\
\text { points }\end{array}$ & $\begin{array}{l}\text { Continuous- } \\
\text { streamflow } \\
\text { record gaging } \\
\text { stations removed }\end{array}$ \\
\hline \multicolumn{6}{|c|}{ Region 2} \\
\hline Annual $Q_{7,2}$ & 79.8 & 52 & 0.12 & 5 & -- \\
\hline$* *$ Annual $Q_{7,2}$ & 316.9 & 81 & 0.10 & 4 & $\begin{array}{l}07356500,07047980 \\
07069265\end{array}$ \\
\hline November-April $Q_{7,10}$ & 69.2 & 46 & 0.12 & 7 & 07247000,07260500 \\
\hline November-December $Q_{7,10}$ & 76.3 & 47 & 0.12 & 6 & 07260500 \\
\hline **January-February $Q_{7,10}$ & 28.7 & 145 & 0.05 & 15 & 07195800,07360200 \\
\hline$* *$ March-April $Q_{7,10}$ & 46.8 & 147 & 0.05 & 11 & -- \\
\hline November $Q_{7,10}$ & 77.4 & 46 & 0.17 & 7 & 07247000,07362100 \\
\hline$* *$ December $Q_{7,10}$ & 76.5 & 145 & 0.05 & 13 & 07068880,07069400 \\
\hline **January $Q_{7,10}$ & 49.7 & 147 & 0.05 & 11 & -- \\
\hline$* *$ February $Q_{7,10}$ & 16.3 & 146 & 0.05 & 17 & 07195800 \\
\hline$* * \operatorname{March} Q_{7,10}$ & 31.2 & 136 & 0.05 & 15 & 07195800 \\
\hline April $Q_{7,10}$ & 43.7 & 60 & 0.07 & 9 & -- \\
\hline
\end{tabular}


Table 2-1. Statistical summary of the coefficient values used in the regression models for each low-flow characteristics of interest.-Continued

$\left[\mathrm{Q}_{7,10}\right.$, 7-day, 10-year low flow; $\mathrm{Q}_{7,2}$, 7-day, 2-year low flow; **, Insufficient data for individual equation for region. The statewide equation is used for this calculation. --, no continuous streamflow-record gaging stations were compared from this model]

\begin{tabular}{|c|c|c|c|c|c|}
\hline $\begin{array}{l}\text { Low-flow } \\
\text { characteristic }\end{array}$ & $\begin{array}{l}\text { Standard error } \\
\text { of the model } \\
\text { (percent) }\end{array}$ & $\begin{array}{l}\text { Final number } \\
\text { of points in } \\
\text { regression }\end{array}$ & $\begin{array}{l}\text { Leverage } \\
\text { threshold }{ }^{1} \\
\left.\text { (d, } h_{\text {limit }}\right)\end{array}$ & $\begin{array}{l}\text { Number of } \\
\text { large } \\
\text { leverage } \\
\text { points }^{1}\end{array}$ & $\begin{array}{l}\text { Continuous- } \\
\text { streamflow } \\
\text { record gaging } \\
\text { stations removed }\end{array}$ \\
\hline \multicolumn{6}{|c|}{ Region 3} \\
\hline Annual $Q_{7,2}$ & 104.4 & 30 & 0.26 & 3 & -- \\
\hline Annual $Q_{7,10}$ & 121.0 & 28 & 0.29 & 2 & -- \\
\hline November-April $Q_{7,10}$ & 87.4 & 31 & 0.25 & 4 & 07359800 \\
\hline November-December $Q_{7,10}$ & 97.5 & 31 & 0.25 & 4 & 07359800 \\
\hline January-February $Q_{7,10}$ & 43.6 & 32 & 0.12 & 3 & -- \\
\hline March-April $Q_{7,10}$ & 34.2 & 31 & 0.19 & 2 & 07360200 \\
\hline November $Q_{7,10}$ & 101.2 & 31 & 0.25 & 4 & 07359800 \\
\hline${ }^{*}$ December $Q_{7,10}$ & 76.5 & 145 & 0.05 & 13 & 07068880,07069400 \\
\hline January $Q_{7,10}$ & 50.4 & 32 & 0.12 & 3 & -- \\
\hline February $Q_{7,10}$ & 48.5 & 32 & 0.12 & 3 & -- \\
\hline $\operatorname{March} Q_{7,10}$ & 61.0 & 32 & 0.12 & 2 & -- \\
\hline April $Q_{7,10}$ & 68.7 & 32 & 0.12 & 1 & -- \\
\hline
\end{tabular}

\footnotetext{
${ }^{1}$ See equations (7 and 8) on page 34 for information on leverage thresholds and leverage points.
} 


\section{Appendix 3. Basin Attributes Tested for Significance in the Regression Analysis}

Average basin slope, in percent, is the length of the basin measured along a line areally centered through the drainage divide from the basin outlet (at the point of interest) to where the main channel of the basin extended meets the basin divide (top of basin) divided by the change in elevation from the basin divide to the basin outlet.

Average overland flow distance, in miles, is the average of distances traveled from the centroid of each response unit in the basin to the nearest stream as computed by the Watershed Modeling System (WMS) software (WMS 7.1, Brigham Young University, 2005).

Basin length, in miles, is the length of the basin measured along a line areally centered through the delineated basin from the basin outlet (at the point of interest) to where the main channel of the basin extended meets the basin divide (top of basin).

Basin perimeter, in miles, is the length as measured along the entire drainage-basin boundary.

Basin shape factor, dimensionless, is the ratio of the total drainage area to the basin length.

Basin sinuosity factor, dimensionless, is the ratio of the maximum stream length to the basin length as computed by WMS software.

Coniferous forest, in percent, is the percent of the basin that is coniferous. Defined in 1992 National Land Cover Dataset (NLCD) metadata as areas dominated by trees where 75 percent or more of the tree species maintain their leaves all year. Canopy is never without green foliage.

Deciduous forest, in percent, is the percent of the basin that is deciduous. Defined in NLCD metadata as areas dominated by trees where 75 percent or more of the tree species shed foliage simultaneously in response to seasonal change.

Drainage area, in square miles, is the area measured in a horizontal plane that is enclosed by a drainage divide.

Effective basin width, in miles, is the ratio of the total drainage area to the basin length.

Forest coverage, in percent, calculated from the NLCD as the percent of the basin that is mixed forested.
Maximum flow distance, in miles, is the maximum flow distance within a basin from the start of overland flow to the basin outlet as computed by WMS software.

Maximum flow slope, in foot/foot, is the slope of the maximum flow distance from the start of overland flow to the basin outlet as computed by WMS software.

Maximum stream length, in miles, is the maximum distance from the highest point on a stream within the basin to the basin outlet as computed by WMS software.

Mean annual and seasonal precipitation, in inches, as a basin average along a stream channel is calculated from PRISM average monthly and annual precipitation data for two time periods: 1961 to 1990 and 1971 to 2000. It is based on 2-kilometer grid data. Twenty-two parameters were determined for the two time periods (table 3 ) based on these data:

- annual at the precipitation gage

- seasonal at the precipitation gage (November - April)

- monthly at the precipitation gage (November - April)

- bimonthly at the precipitation gage (November December; January - February; March - April)

Mean basin elevation, in feet, is the mean basin elevation in the drainage basin calculated from digital elevation models of the basin of interest.

Mixed coniferous/deciduous forest, in percent, is the percent of the basin that is mixed coniferous and deciduous. Defined in NLCD metadata as areas dominated by trees where neither deciduous nor evergreen species represent more than 75 percent of the cover present.

Mean permeability, in inches per hour, is the mean permeability in each basin as determined from STATSGO (State Soil Geographic) (Schwarz and Alexander, 1995 and U.S. Department of Agriculture, 2001) data.

Pasture/hay, in percent, is the percent of the basin that is pasture and hay. Defined in NLCD metadata as areas of grasses, legumes, or grass-legume mixtures planted for livestock grazing or the production of seed or hay crops.

Percent facing north, in percent, is the percentage of the basin with an aspect that is directed north as computed by Watershed Modeling System (WMS) software (see Brigham Young University (2005) for further explanation). 
Percent facing south, in percent, is the percentage of the basin with an aspect that is directed south as computed by WMS software (see Brigham and Young (2005) for further explanation).

Percent Mississippian, in percent, is the percent of the basin that has surficial geology that is of Mississippian age as defined by the Geologic Map of Arkansas (Haley and others, 1976).

Percent Ordovician, in percent, is the percent of the basin that has surficial geology that is of Ordovician age as defined by the Geologic Map of Arkansas (Haley and others, 1976).

Percent Mississippian, Ordovician, Kn, Kt, Kto, and Tw, in percent, is the percent of the basin that has surficial geology that is of Mississippian, Ordovician, select Cretaceous

(Kn - Nacatoch Sand; Kt -Trinity Formation; and Kto - Tokio

Formation) and select Tertiary (Tw - Wilcox Group) age as defined by the Geologic Map of Arkansas (Haley and others, 1976).

Row crops, in percent, is the percent of the basin that is used for row crops. Defined in NLCD metadata as areas used for the production of crops, such as corn, soybeans, vegetables, tobacco, and cotton.

Soil drainage, in percent, is the percentage of drainage basin that is well drained as determined from STATSGO (State Soil Geographic) (Schwarz and Alexander, 1995 and U.S. Department of Agriculture, 2001) data.

Soil hydrologic group, dimensionless, is a single value numeric code identifying a composite of the hydrologic characteristics of the soil in the basin. As defined from STATSGO (State Soil Geographic) data, numeric codes are as follows: 1 - high infiltration, deep soils, well drained to excessively drained sands and gravels, 2 - moderate infiltration rates, deep and moderately deep, moderately well and well drained soils with moderately coarse textures, 3 - slow infiltration rates, soils with layers impeding downward movement of water, or soils with moderately fine or fine textures, and 4 - very slow infiltration rates, soils are clayey, have a high water table, or are shallow to an impervious layer (Schwarz and Alexander, 1995; U.S. Department of Agriculture, 1991). 


\section{Appendix 4. Basin Attribute Selection}

Before the determination of the best set of basin attributes (table 3 ) to use as predictor variables in multiple linear regression models, two dimensional plots of the different combinations of basin attributes were examined, and a Pearson correlation value was computed. For two paired basin attributes, if their Pearson correlation value was greater than 0.5, then one of these two attributes was eliminated from consideration in the study. To decide which basin attribute to eliminate, additional Pearson correlation values were computed for each basin attribute to the low-flow characteristic of interest, and the attribute having the highest correlation was retained in the analysis. When two different precipitation attributes were considered, the plots and Pearson correlations were not examined because precipitation attributes tend to be highly correlated with one another $(p>0.7)$. Instead, each of the 42 precipitation variables, one at a time, was allowed into the selection analysis with the remaining 22 basin attributes not related to precipitation. This procedure was done to minimize the amount of redundant information or multicollinearity among the basin attributes that would be used in the regression models. Table 4-1 lists the basin attributes removed from this procedure leaving 64 out of the original 75 basin attributes.

Table 4-1. Basin attributes removed from regression analysis after two-dimensional plots indicated moderate correlation.

[Moderate correlation indicated when Pearson's correlation rho was greater than 0.5$]$

Percent of the basin facing north, in percent

Percent of the basin facing south, in percent

Maximum flow distance, in feet

Maximum stream slope, in foot per foot

Maximum flow slope, in foot per foot

Maximum stream length, in feet

Effective basin width, in feet

Basin perimeter, in feet

Total forest, in percent

Soil drainage, in percent

Basin length, in feet
Basin attributes were selected individually for each regression. Selection of a set of statistically significant basin attributes was done by four methods (best subsets, forwardselection, backward-elimination, and stepwise selection using OLS parameter fits; Montgomery and others, 2001) within each physiographic region of Arkansas. A set of basin attributes was selected when they were found to be statistically significant $(p<0.05)$ and overlapped in all four methods. An additional criterion was that the final set of basin attributes was to have no more than three basin attributes to reduce overfitting of the regression model and minimize the amount of multicollinearity. The three basin attributes were selected from a list of ranked basin attributes based on their $p$-values.

The metric used to measure the amount of multicollinearity that is present in the regression model is the VIF statistic (Montgomery and others, 2001):

$$
V I F_{k}=\frac{1}{1-R_{k}^{2}}
$$

where

$$
\begin{aligned}
& k \quad \text { is the } k^{\text {th }} \text { predictor variable in a regression } \\
& \text { model, and } \\
& R_{k}^{2} \quad \text { is the coefficient of determination obtained } \\
& \text { from regressing the kth basin attribute on } \\
& \text { all the remaining basin attributes in the } \\
& \text { regression model. }
\end{aligned}
$$

A $V I F_{k}$ value greater than 5-10 generally indicates that multicollinearity is a serious problem in the regression model, and the highly correlated variables were removed from the regression model. The attribues with a $V I F_{k}$ value less than five were chosen as the final set of predictor variables to form a regression model.

A constant of 1 percent was added to any basin attribute reported as a percentage, and if several basin attribute values for individual basins were equal to one, the constant of one was not optimized to linearize the regression model. This nonoptimization treated the basin attribute as a pseudo-binary response variable. This basin-attribute selection procedure was repeated for all of the regression models presented in this report, resulting in 15 unique basin attributes used in the regression models (table 4-2). 


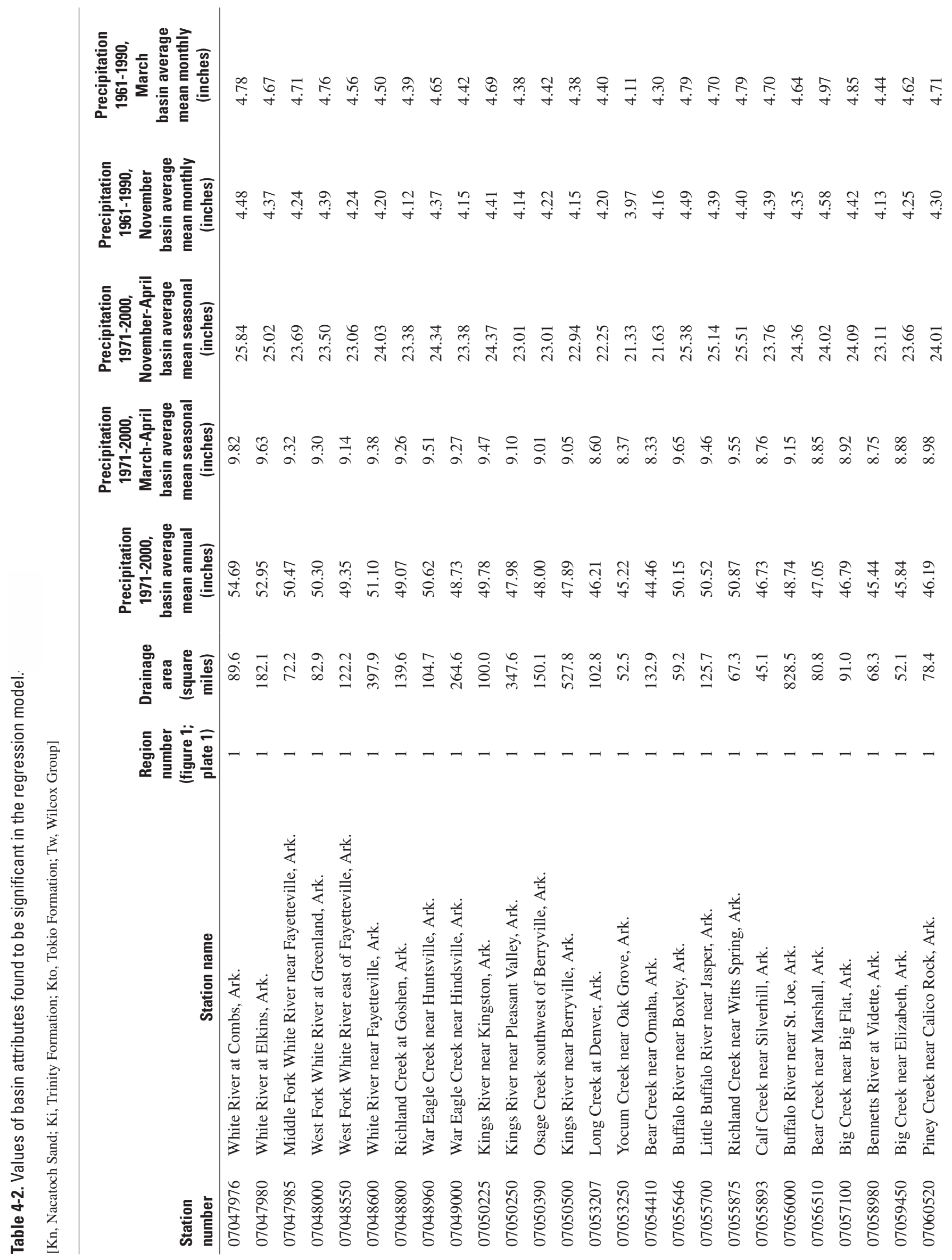




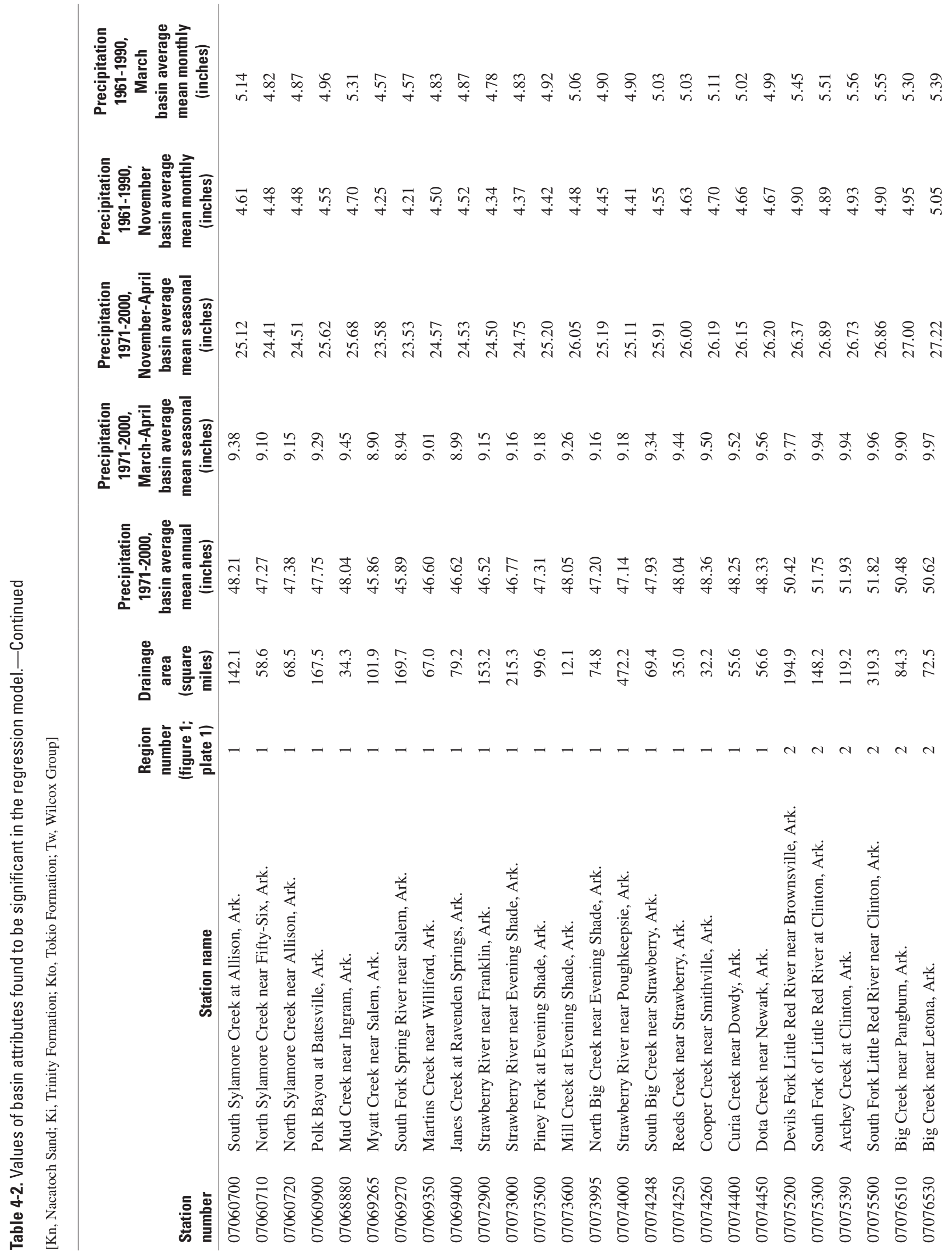




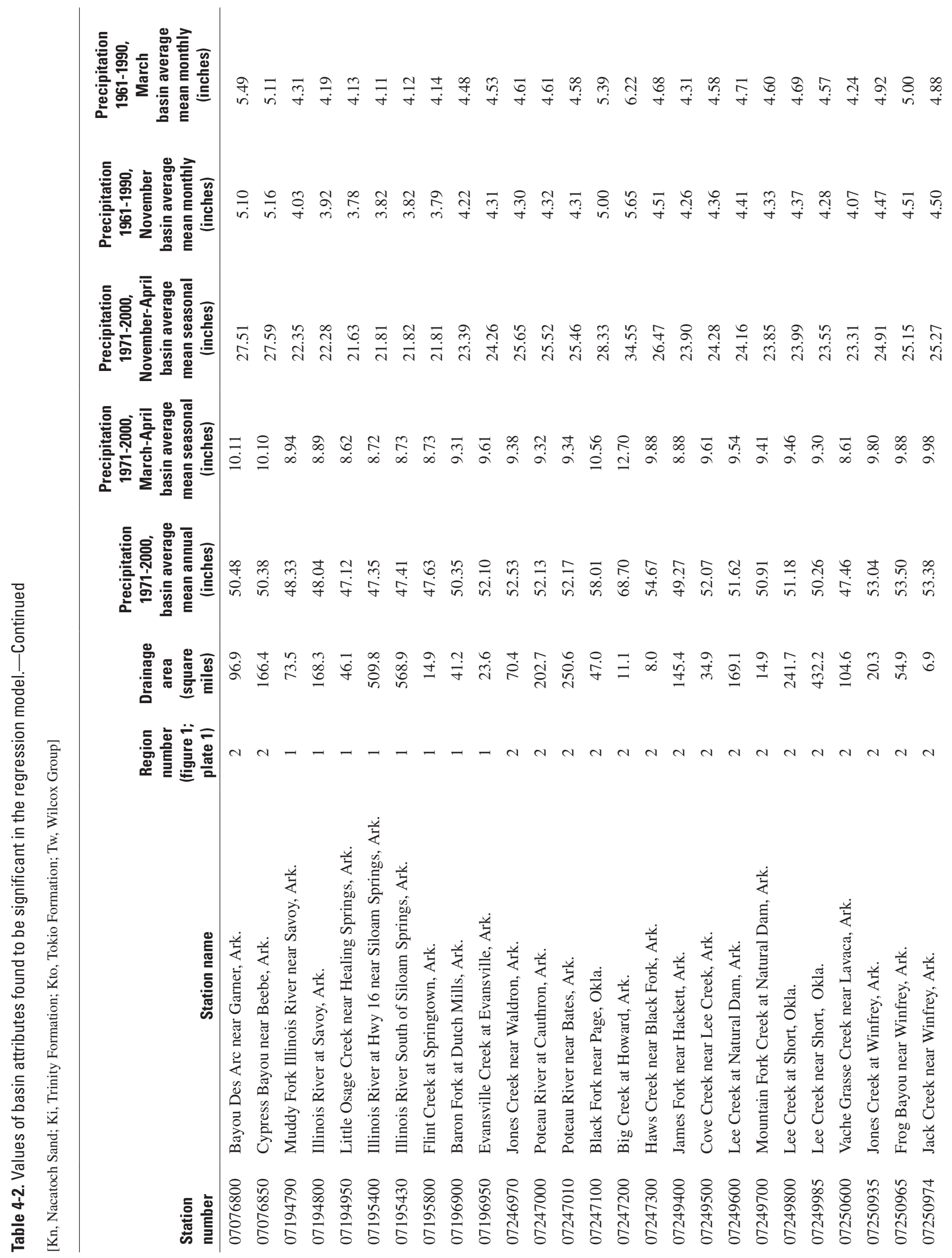




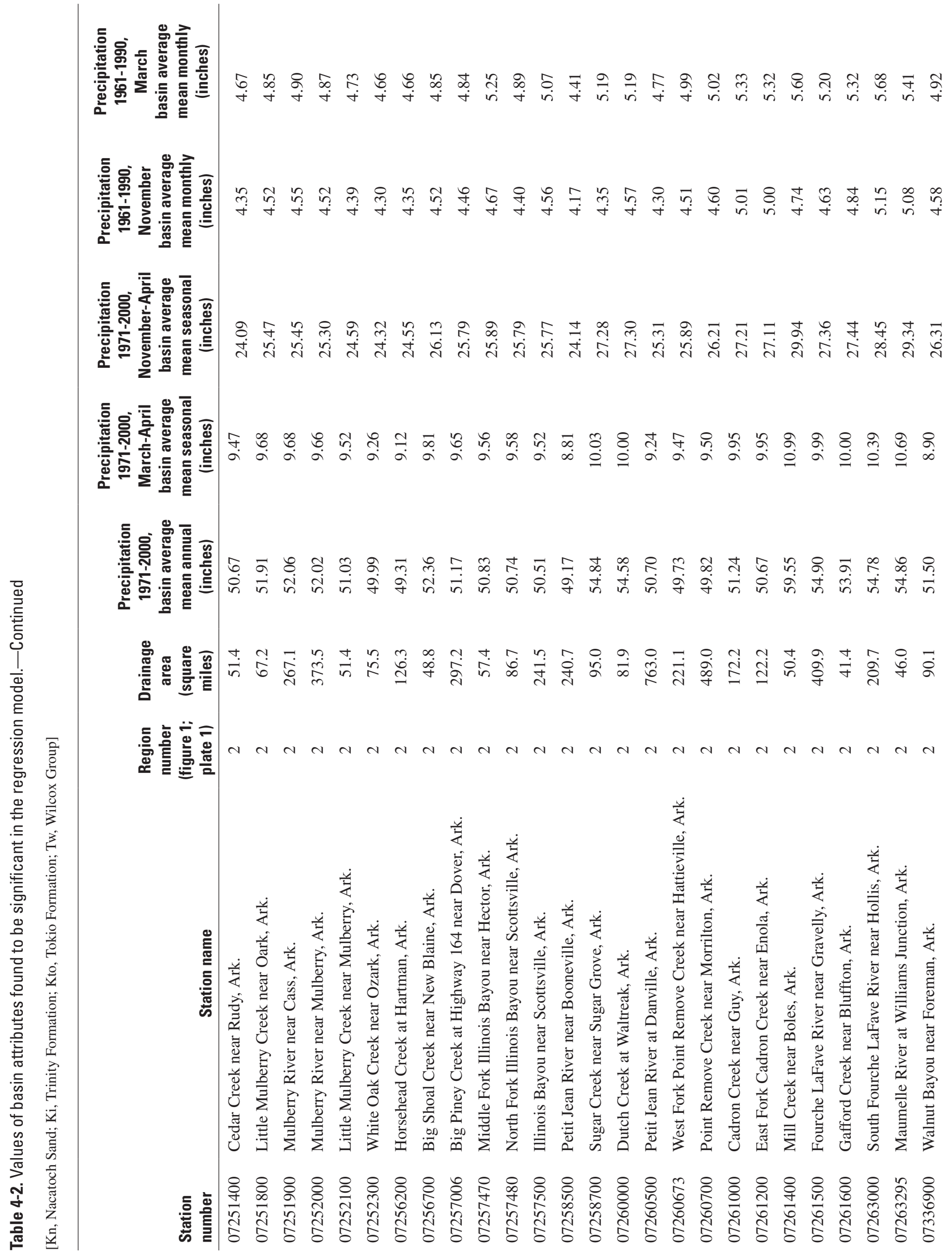




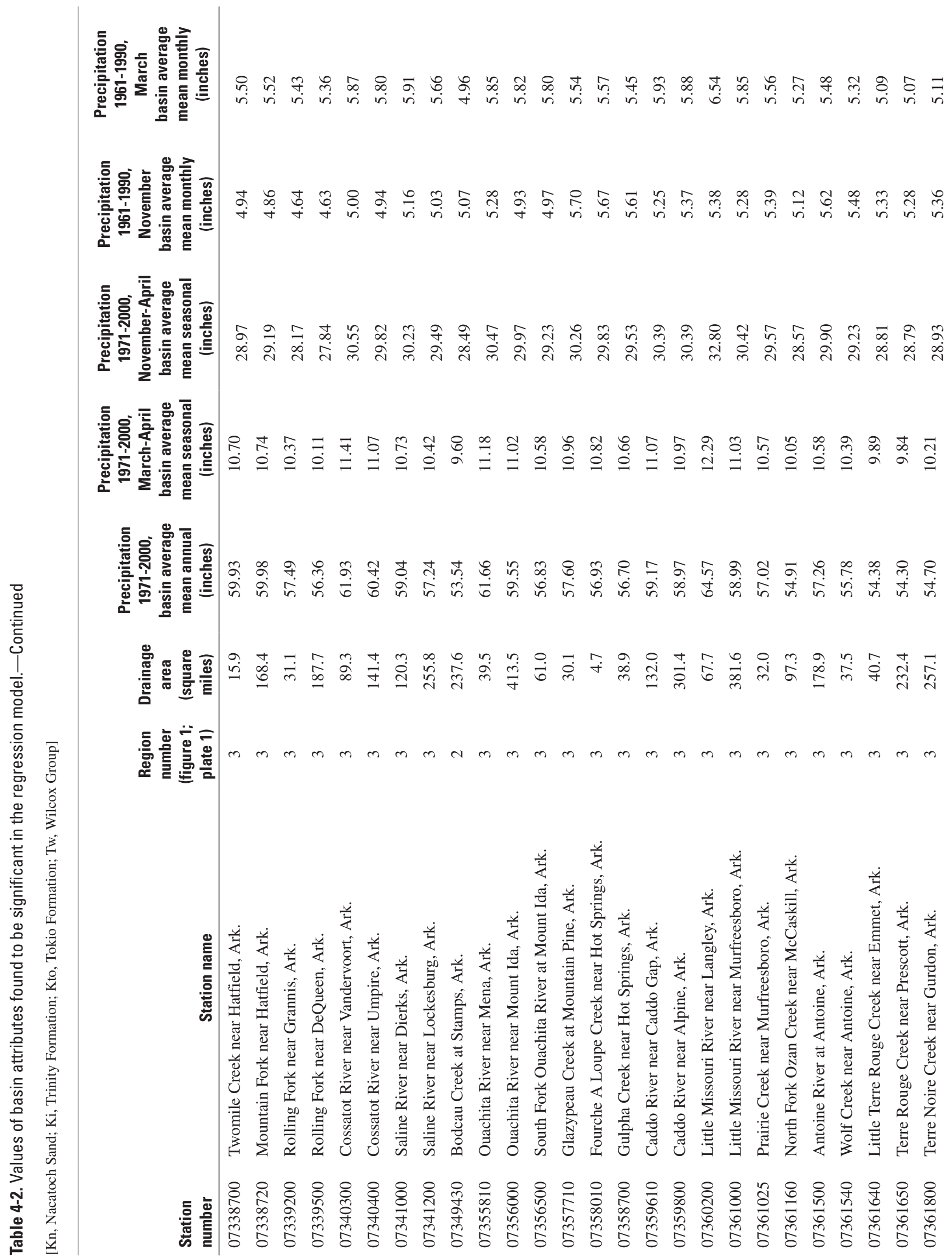




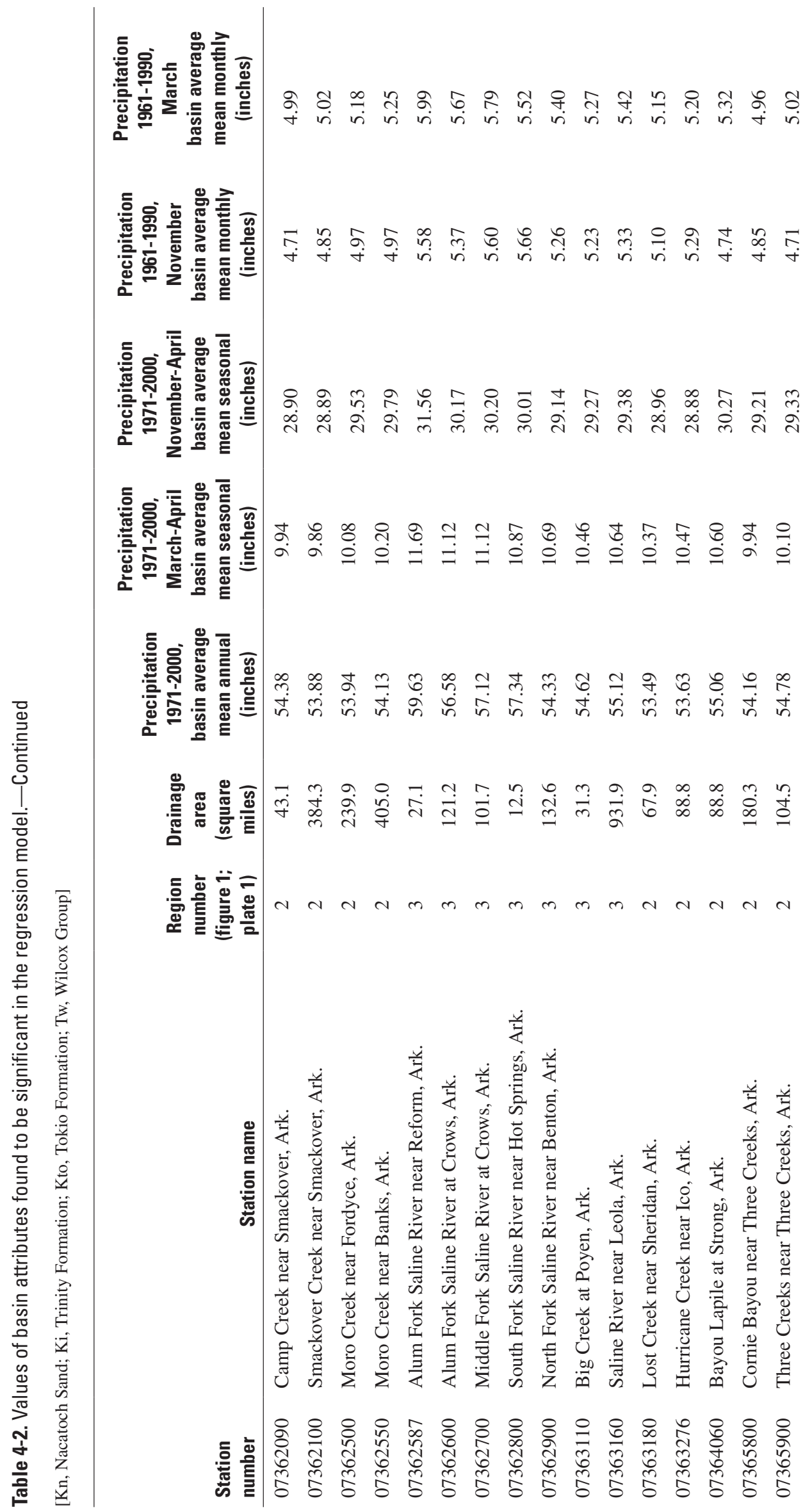




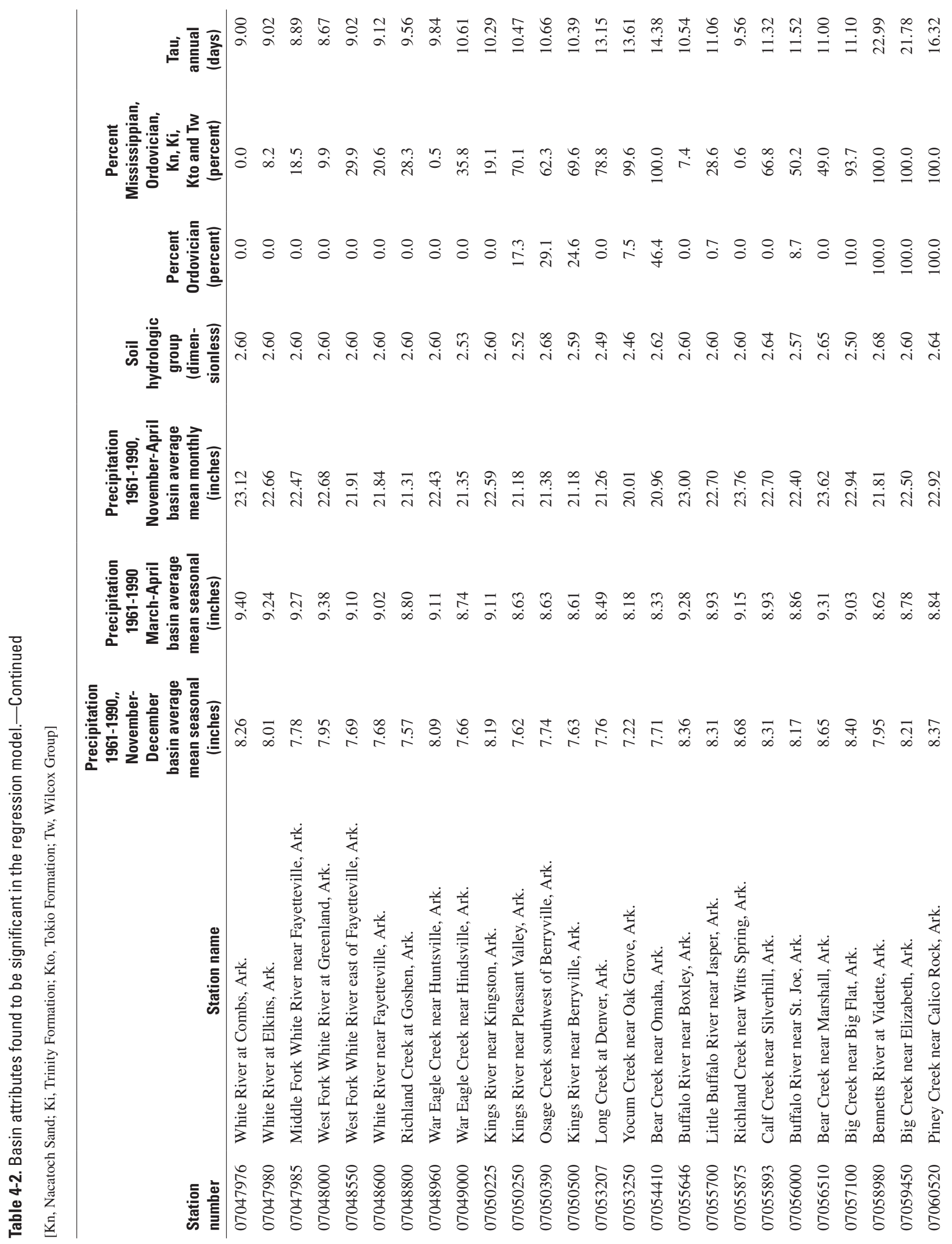




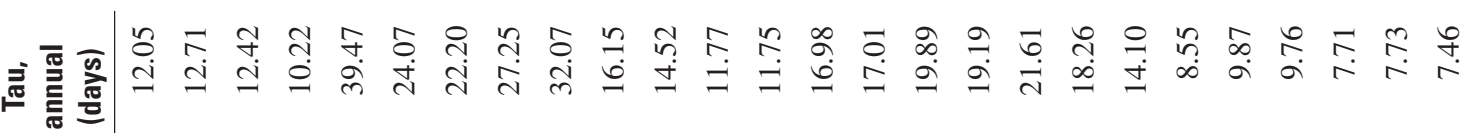

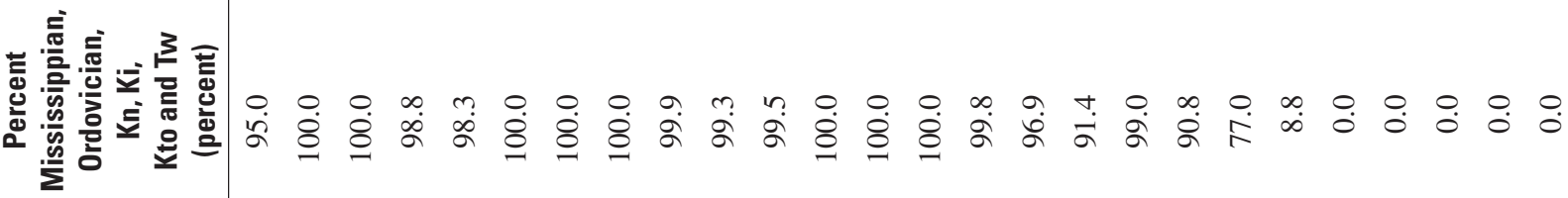

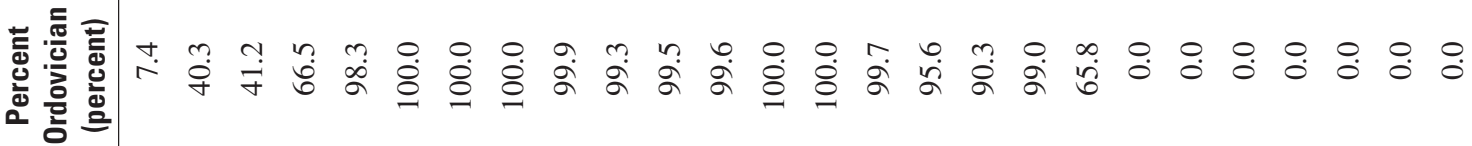

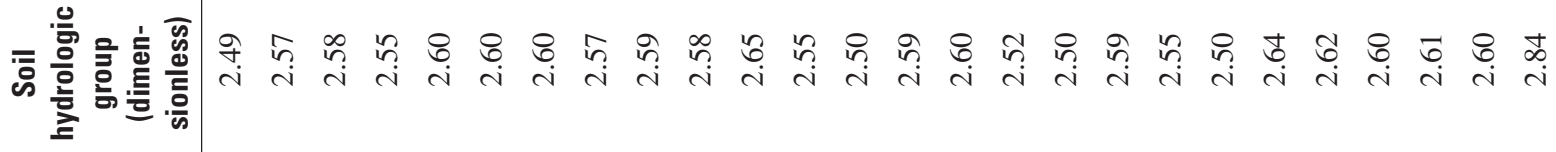

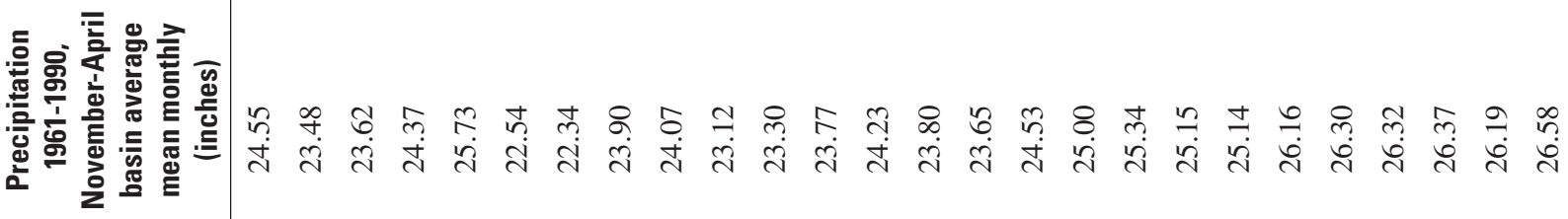
든

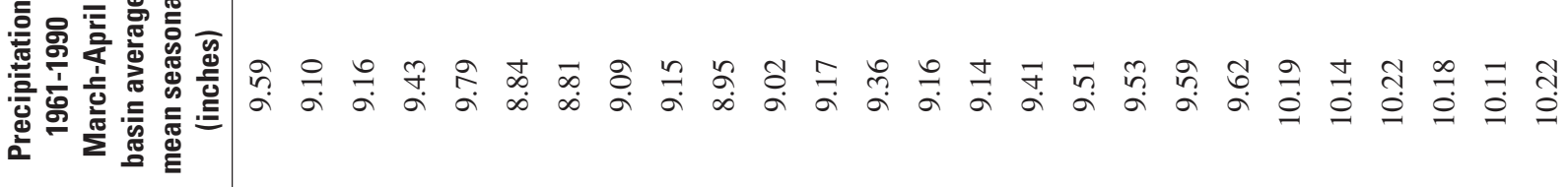

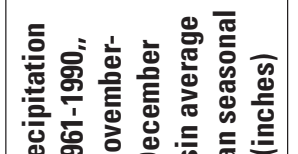

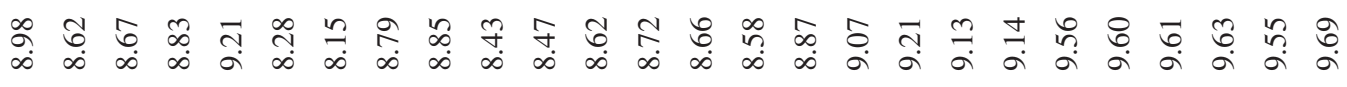
口.

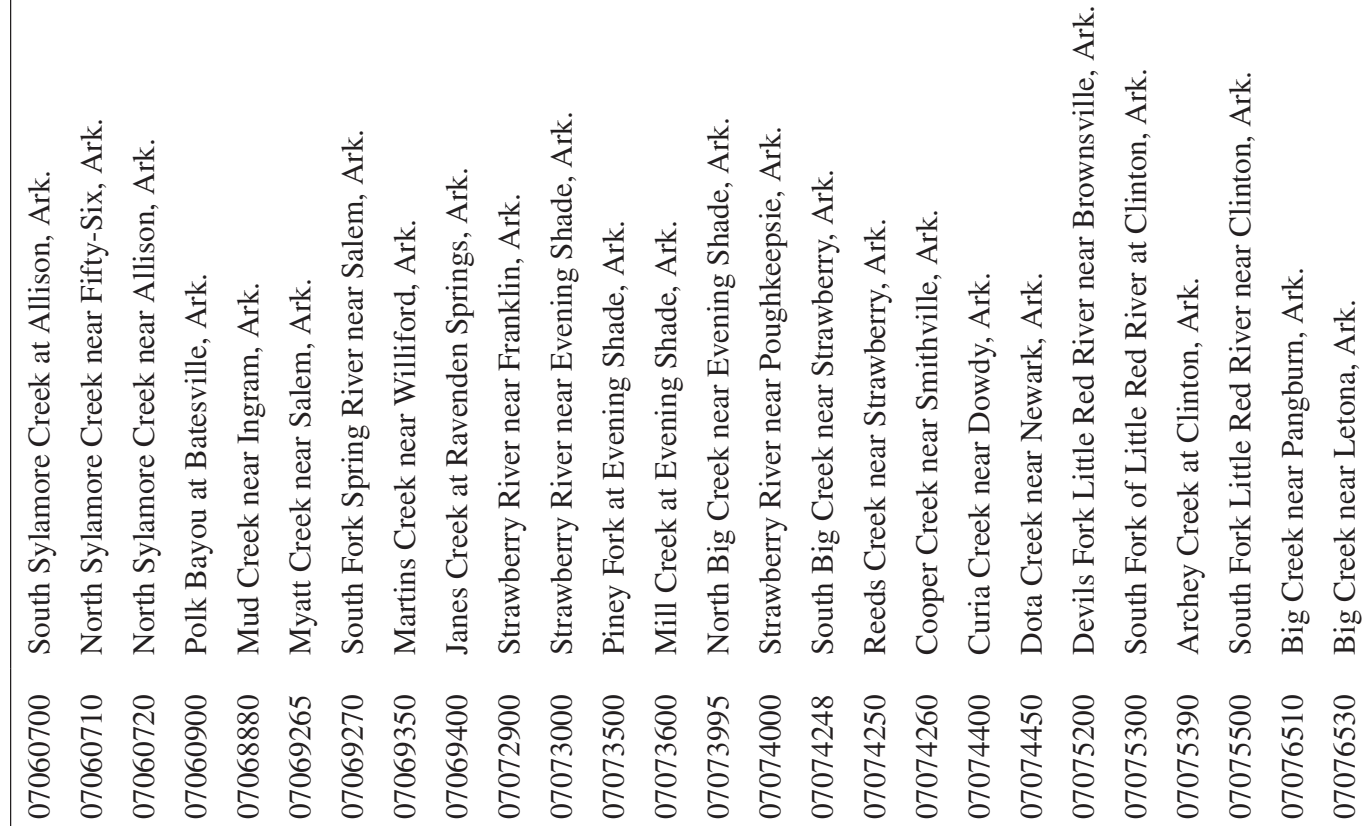




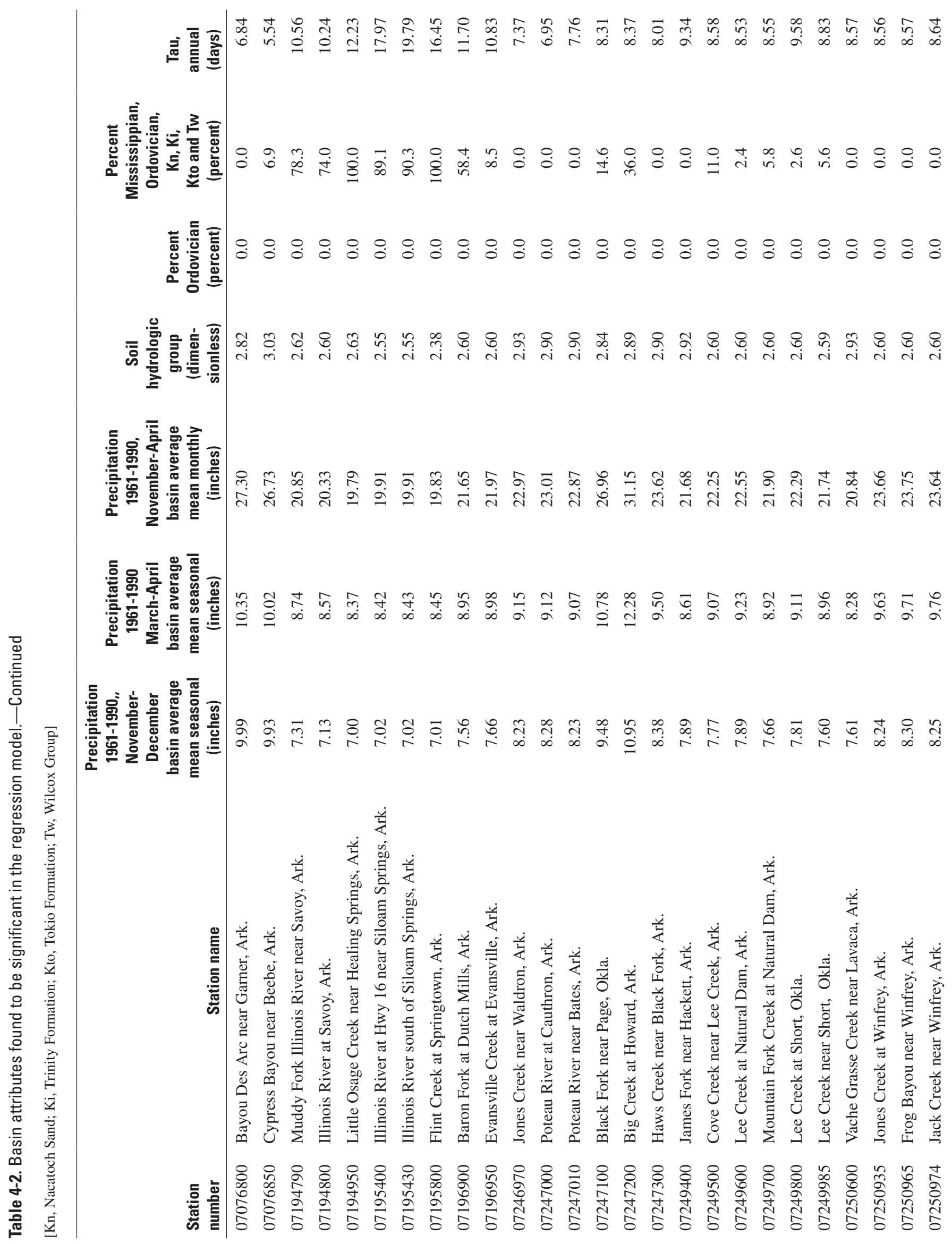




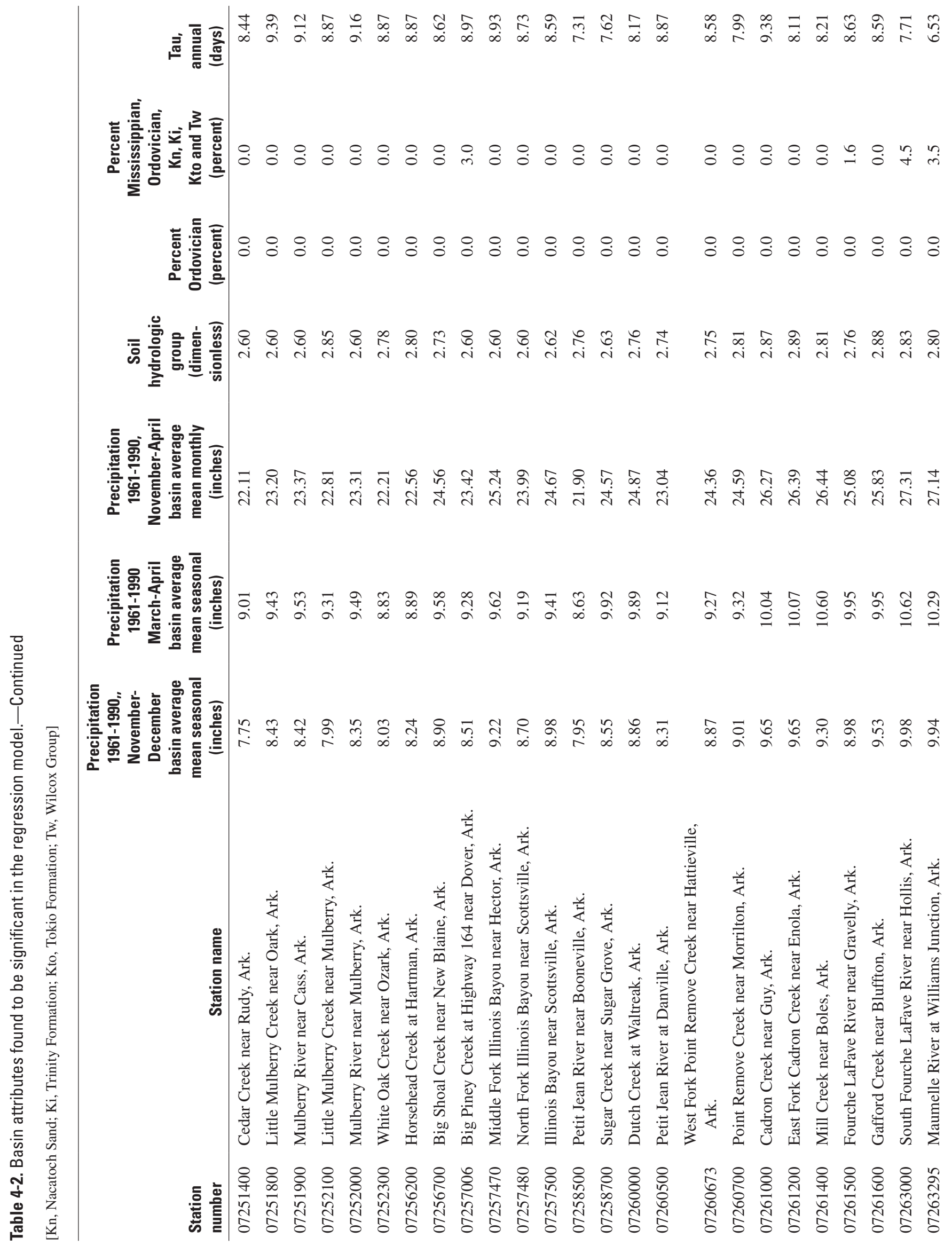




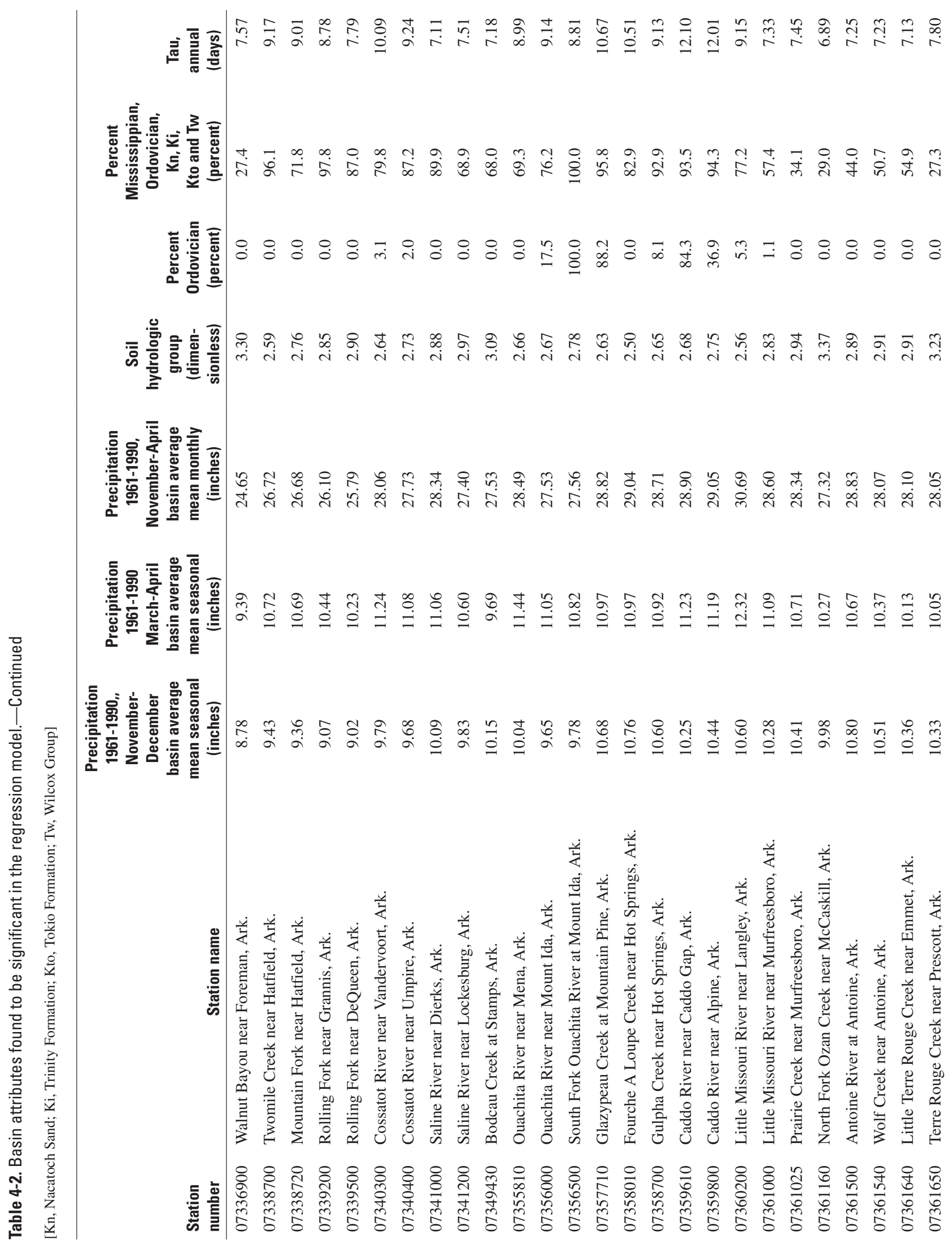




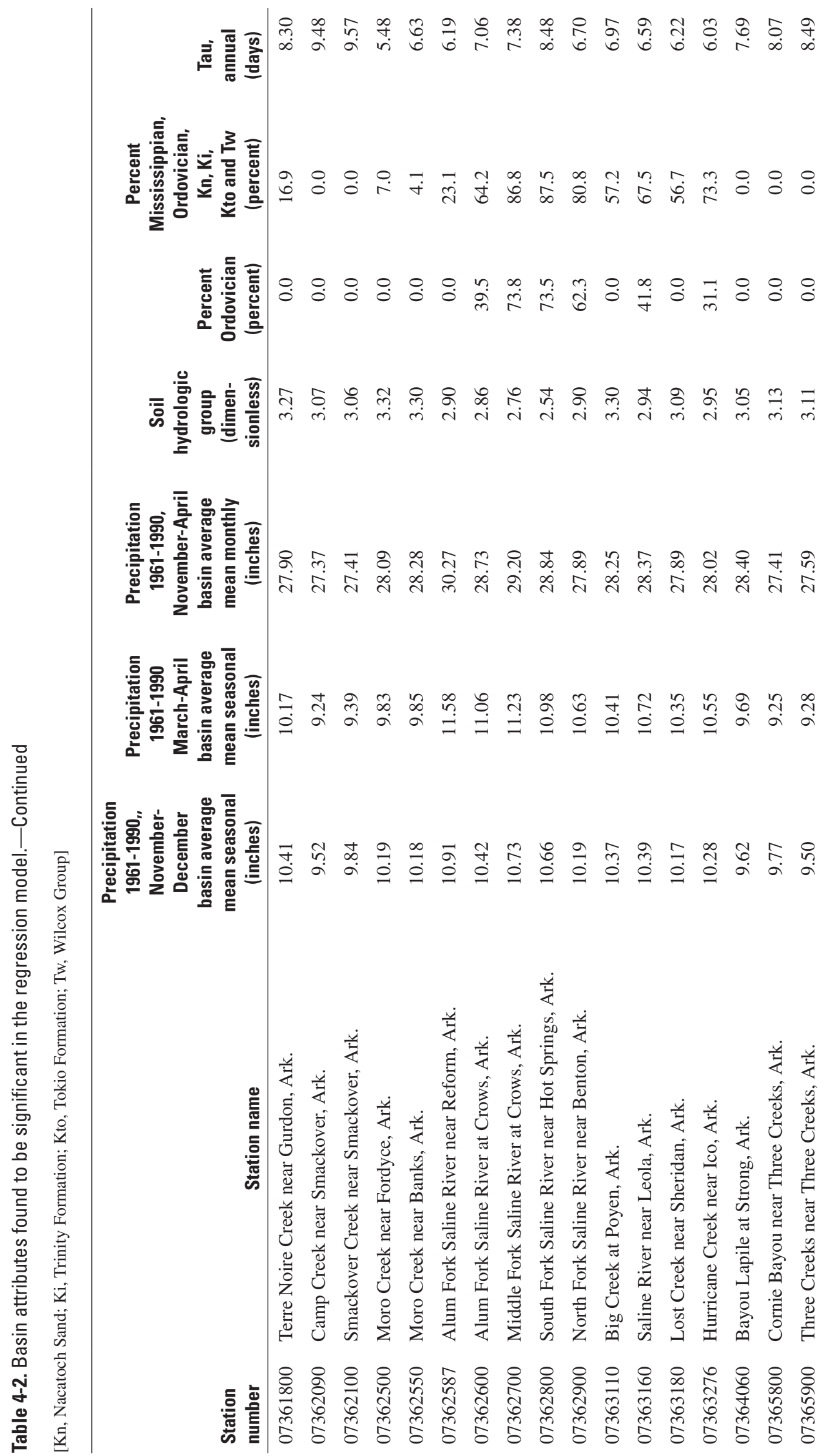




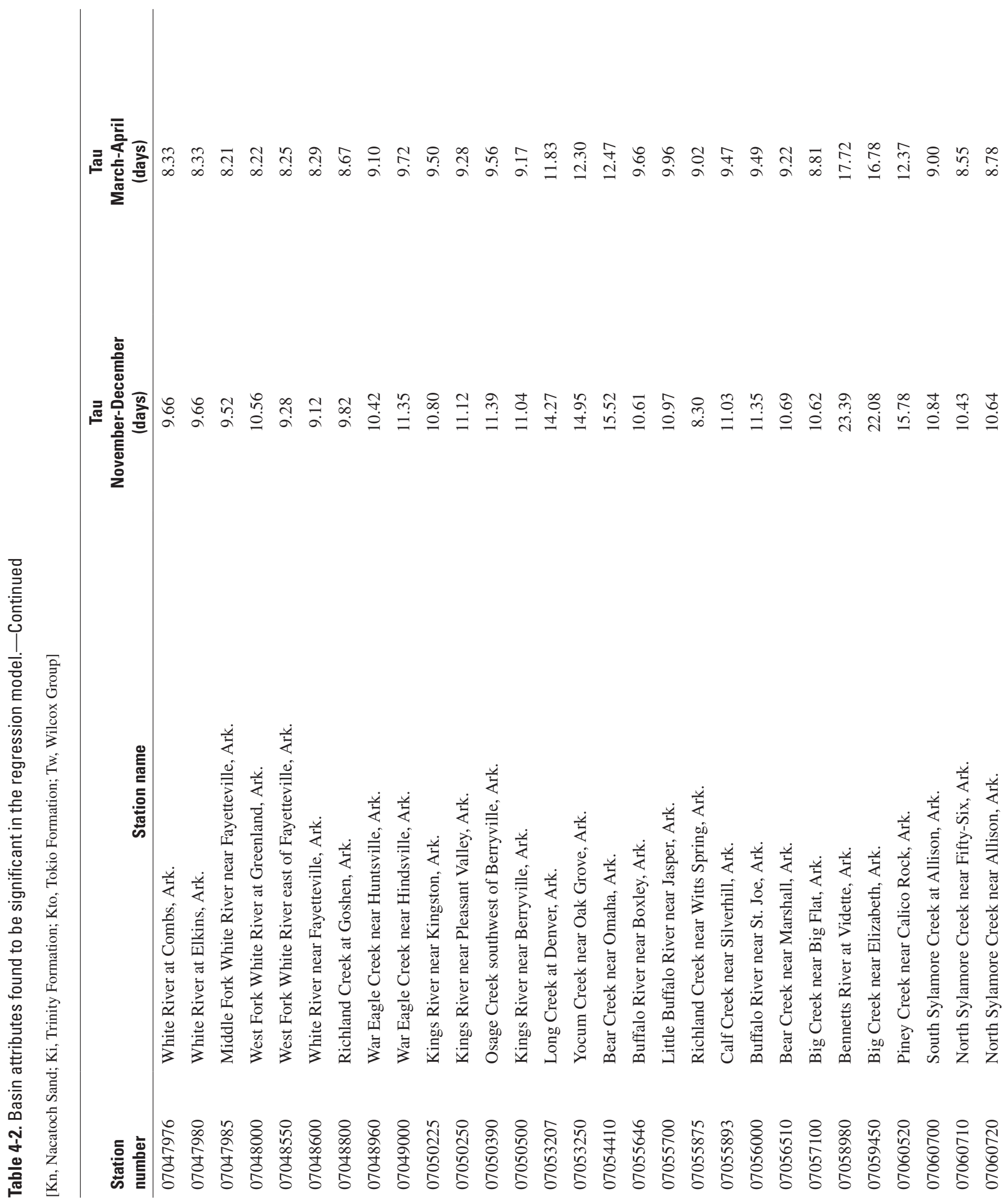




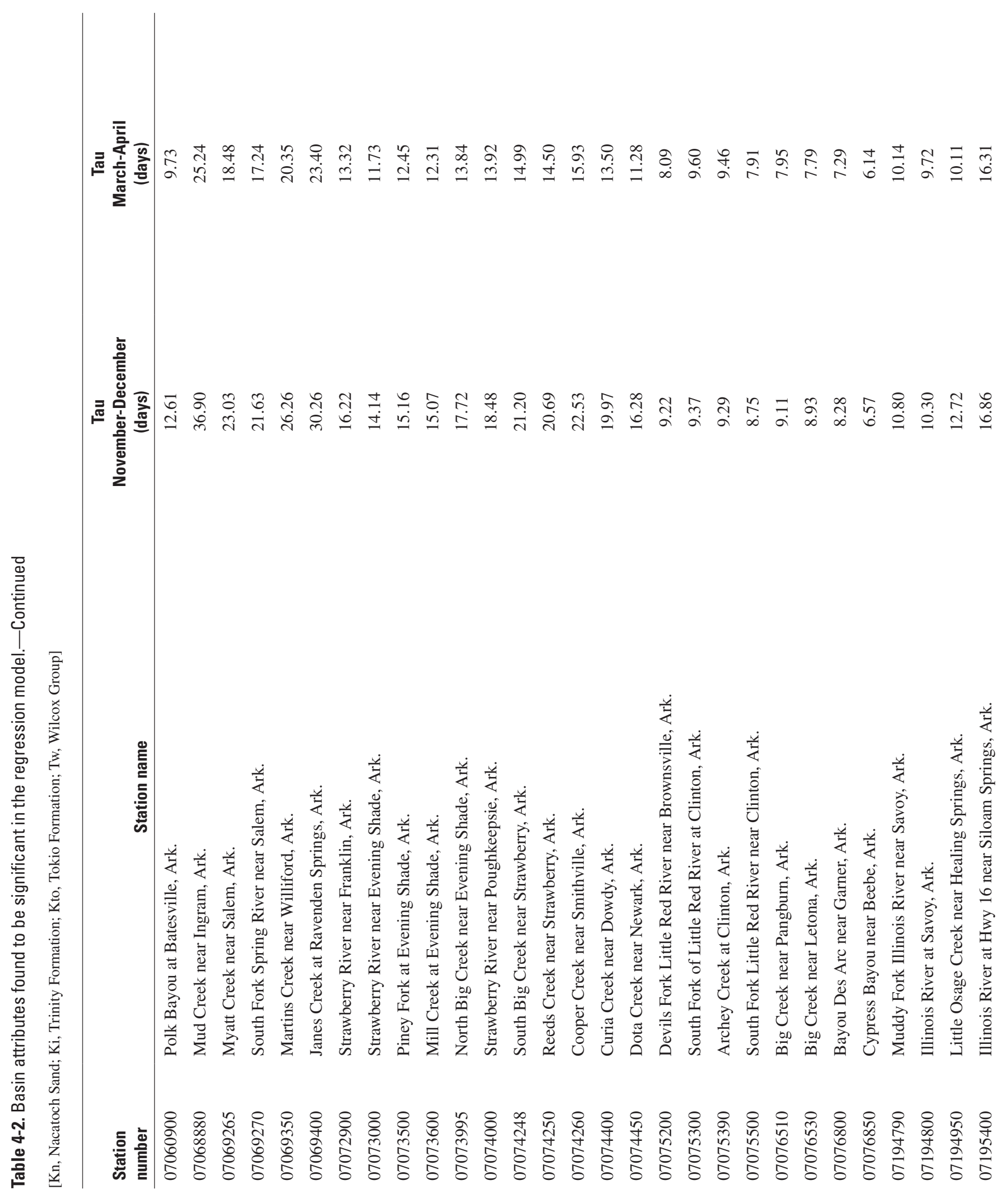




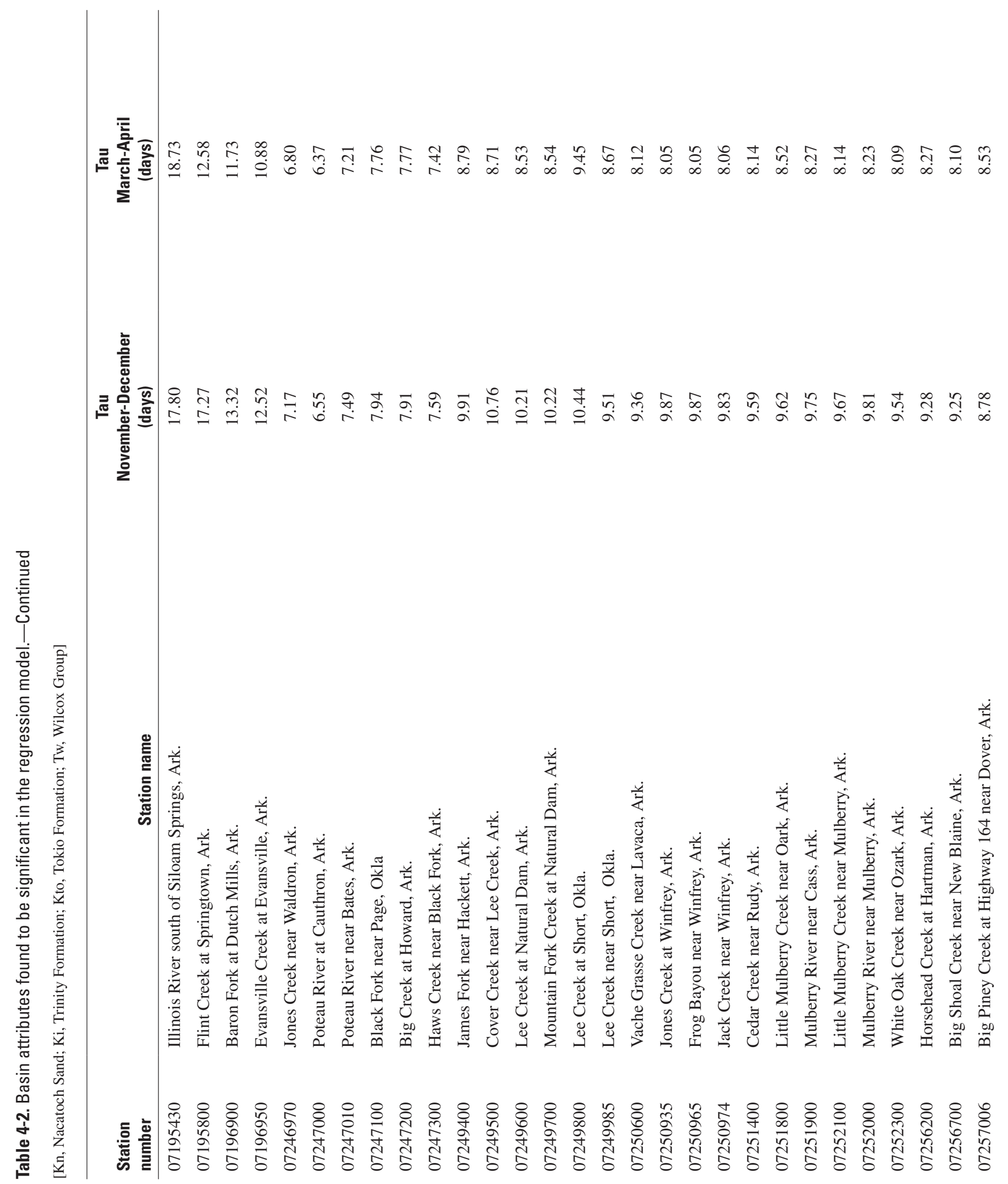




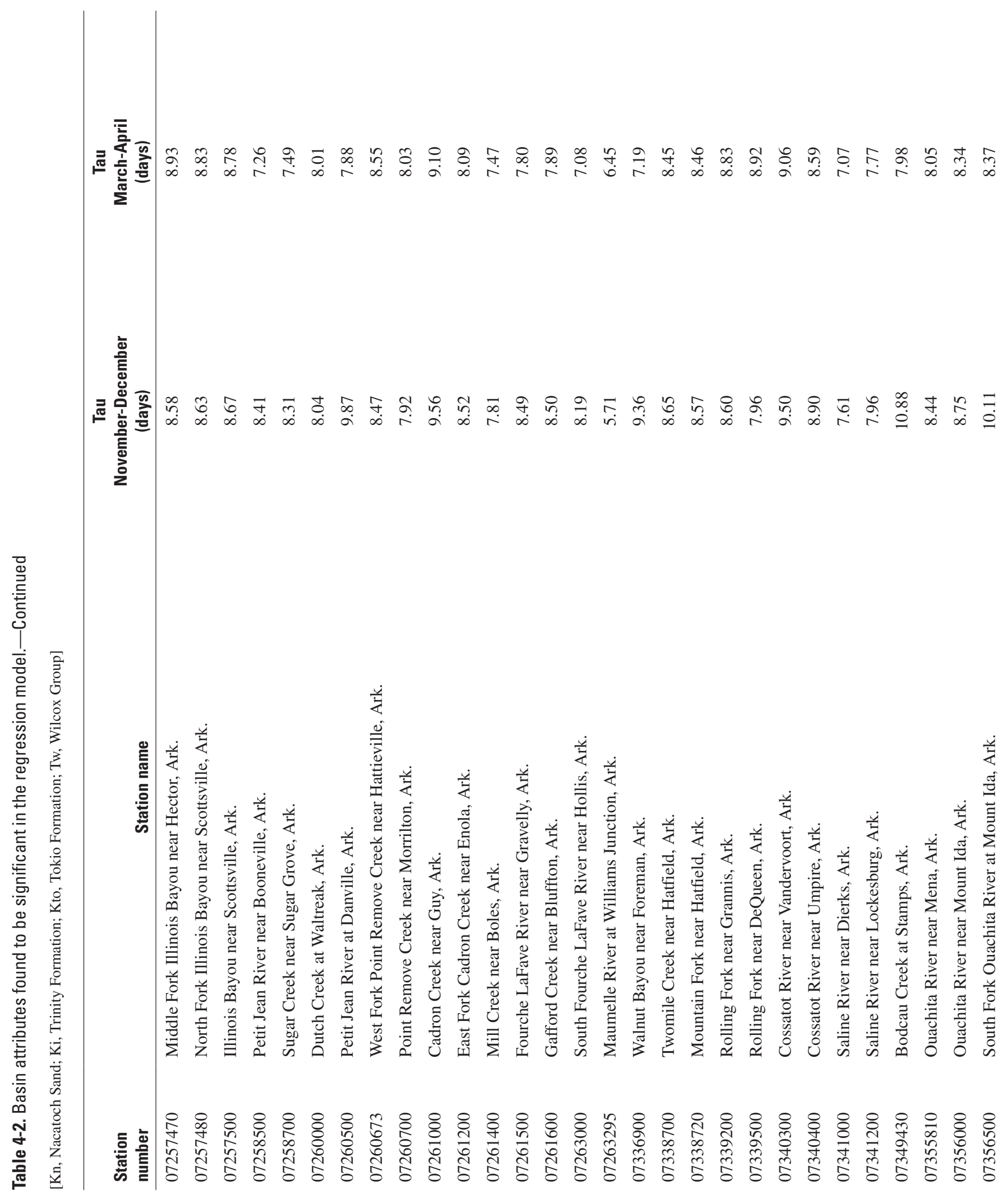




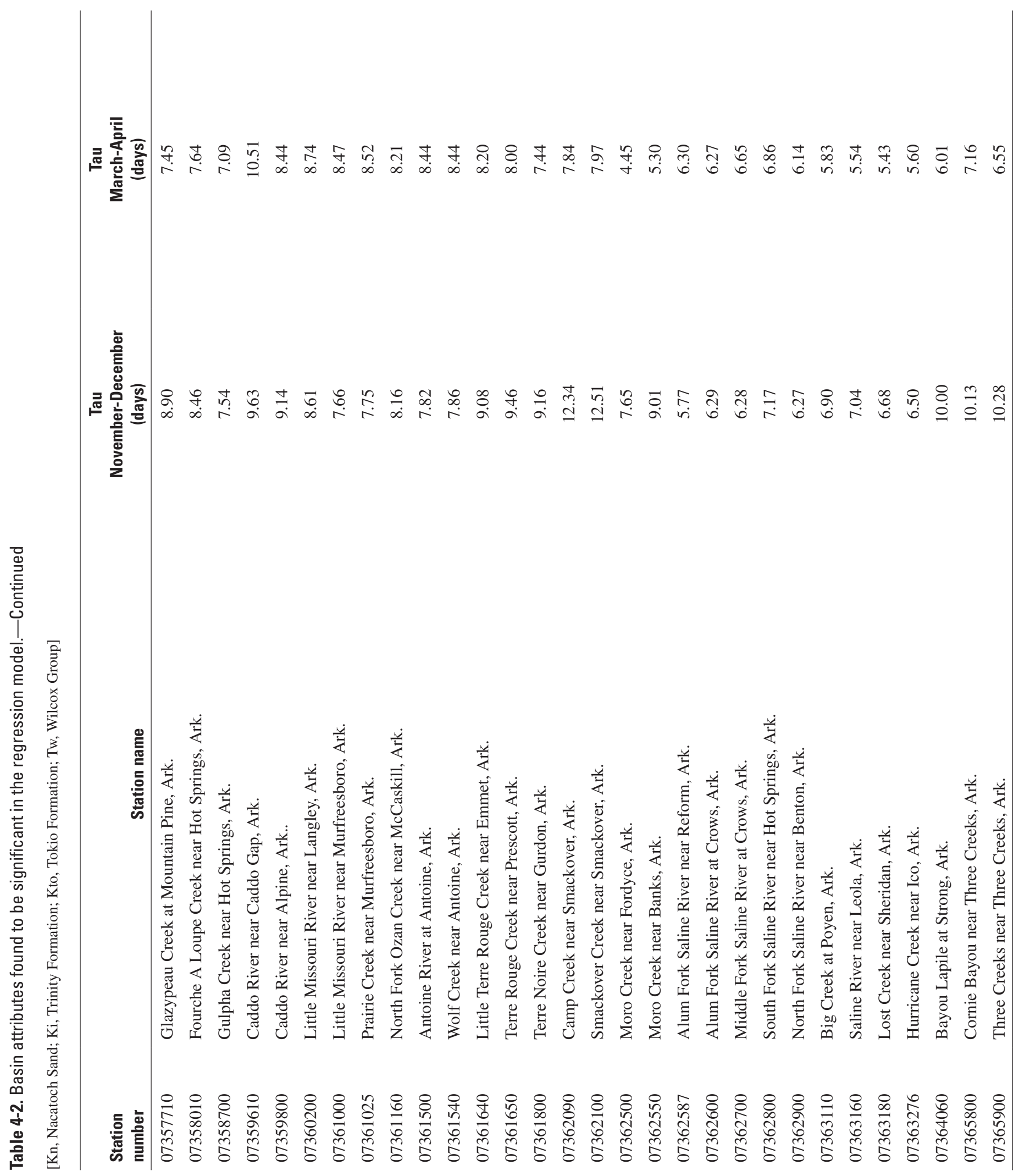


Publishing support provided by:

Lafayette and Rolla Publishing Service Centers

For more information concerning the research described in the report:

U.S. Geological Survey Arkansas Water Science Center

401 Hardin Road

Little Rock, AR 72211-3528

(501) 228-3600

http://ar.water.usgs.gov 


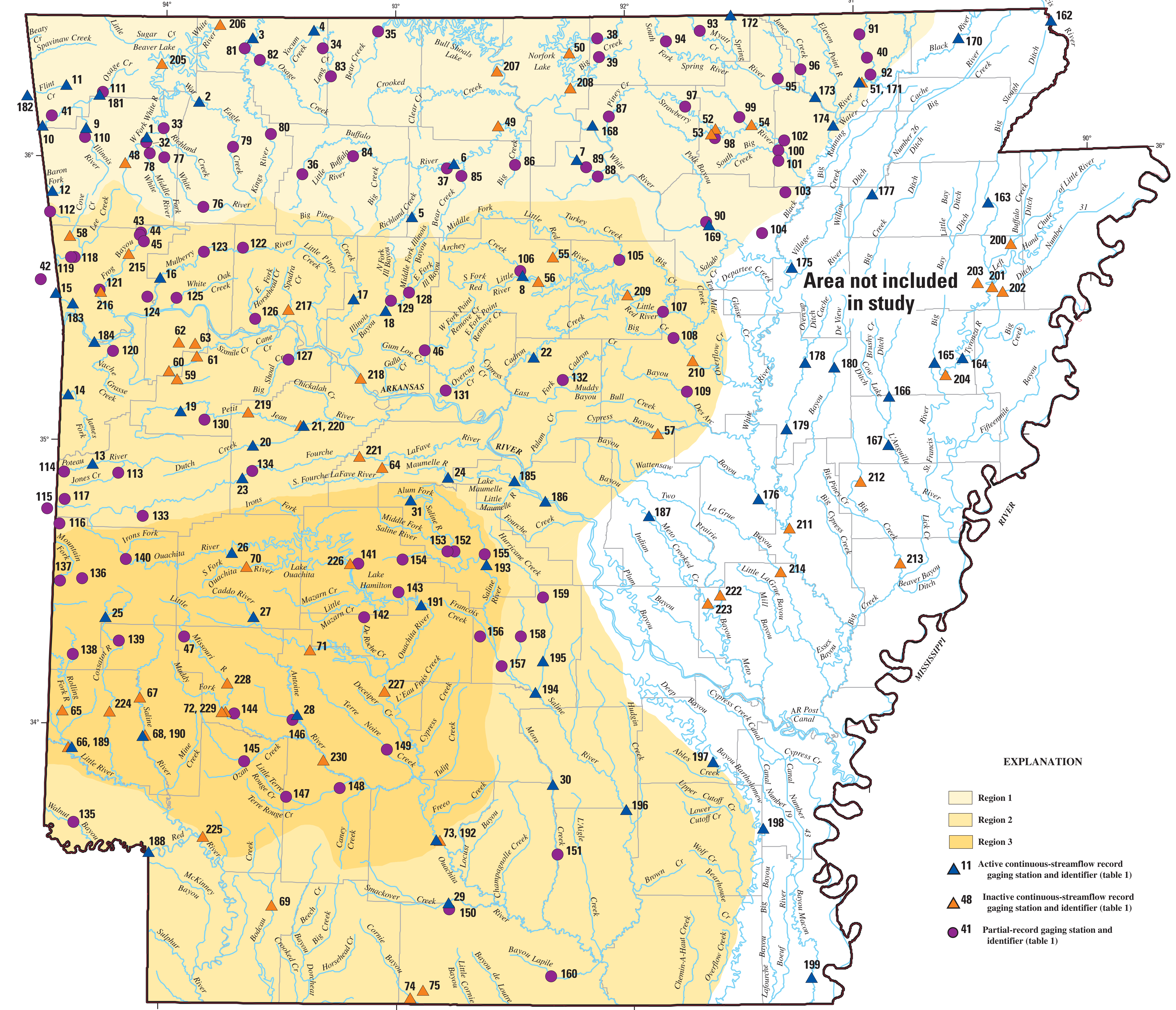

Low-Flow Regions of Arkansas

Jaysson E. Funkhouser, Ken Eng, and Matthew W. Moix 


\section{要}

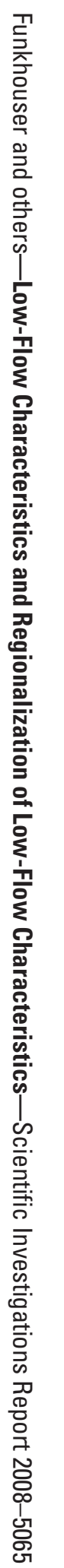

63 Printed on recycled paper 